UNIVERSIDADE DE SÃO PAULO

ESCOLA DE COMUNICAÇÕES E ARTES

\title{
EDUCAÇÃO MUSICAL A DISTÂNCIA: PROPOSTAS PARA ENSINO E APRENDIZAGEM DE PERCUSSÃO
}

DANIEL MARCONDES GOHN

SÃO PAULO

2009 


\section{DANIEL MARCONDES GOHN}

\section{EDUCAÇÃO MUSICAL A DISTÂNCIA: PROPOSTAS PARA ENSINO E APRENDIZAGEM DE PERCUSSÃO}

Tese apresentada ao Programa de Pós-Graduação em Ciências da Comunicação da Escola de Comunicações e Artes da Universidade de São Paulo, como requisito parcial para a obtenção do Título de Doutor em Ciências da Comunicação.

Orientador: Prof. Dr. Fredric Michael Litto.

Área de concentração: Interfaces Sociais da Comunicação

SÃO PAULO 2009 
EDUCAÇÃO MUSICAL A DISTÂNCIA: PROPOSTAS PARA ENSINO E APRENDIZAGEM DE PERCUSSÃO

\section{DANIEL MARCONDES GOHN}

Tese apresentada à Escola de Comunicações e Artes da Universidade de São Paulo, como requisito parcial para a obtenção do Título de Doutor em Ciências da Comunicação.

Aprovado em:

$I_{-} I_{-}$

Banca Examinadora

Prof. Dr.

Instituição:

Assinatura:

Prof. Dr. Instituição:

Assinatura:

Prof. Dr. Instituição:

Assinatura:

Prof. Dr. Instituição:

Assinatura:

Prof. Dr. Instituição: 


\section{AGRADECIMENTOS}

Durante a elaboração deste trabalho tive amplas condições de amadurecer minha carreira como pesquisador. Apresento aqui meus sinceros agradecimentos a todos que contribuíram para que isso fosse possível, participando desse momento importante da minha vida e trazendo elementos essenciais para a concretização do projeto.

Ao meu orientador, Prof. Dr. Fredric Michael Litto, pela inspiração, ensinamentos, confiança, incentivo e oportunidades. Conviver com tamanha sabedoria e bom humor tanto no mestrado como no doutorado foi um grande privilégio.

Ao Conselho Nacional de Desenvolvimento Científico e Tecnológico (CNPq), pela bolsa de estudos e pelo apoio institucional que viabilizou a realização da tese.

À Profa. Dra. Luciana Del Ben e ao Prof. Dr. Pedro Paulo Salles, pelas críticas, sugestões e comentários preciosos durante a fase de qualificação do trabalho. Agradeço à Profa. Luciana também pelo incentivo para desenvolver essa pesquisa, durante uma conversa no Encontro da ABEM, em 2005.

Ao Prof. Dr. Glauber Santiago, pela confiança ao me convidar para o trabalho no projeto da UAB - UFSCar.

À equipe do curso de Licenciatura em Educação Musical da UAB - UFSCar.

Aos meus colegas do Projeto Tonomundo, na Escola do Futuro da USP: Vera Laporta, Ana Karina Souza, Sílvia Fichmann e Leandro Thesin.

Aos funcionários da Secretaria de Pós-Graduação da ECA, pela atenção e serviços prestativos durante o período de estudos.

Aos meus amigos e colegas da música Jayme Pladevall, Pepa D’Elia e Alex Reis (grupo Casa de Marimbondo), Felipe Veiga e Edinei Lima (grupo Tribores), que me ensinaram grande parte do que conheço no universo da percussão.

À Liana e ao Lula, pela acolhedora hospitalidade nas minhas estadias em Valinhos.

Aos meus pais, Renato e Maria da Glória Gohn, que sempre encheram minha vida de alegria, estímulos e possibilidades, fazendo de mim o que sou hoje. Vocês são os melhores pais do mundo.

À Talitha, meu grande amor, meu time, sempre. 


\section{RESUMO}

GOHN, Daniel M. Educação musical a distância: propostas para ensino e aprendizagem de percussão. 2009. Tese (doutorado). Escola de Comunicações e Artes, Universidade de São Paulo, São Paulo, 2009.

Esta tese tem como tema a educação musical a distância. Tomando como ponto de partida o atual contexto de música e tecnologia, com as facilidades e problemáticas trazidas pelas amplas possibilidades comunicacionais do mundo moderno, o assunto é abordado tendo em vista a formação de professores de música. O objetivo desse estudo é investigar a viabilidade do ensino a distância em uma disciplina de percussão, dentro de um programa de formação de educadores musicais. Para a consecução desse objetivo, a disciplina "Percussão" foi desenvolvida e ministrada no âmbito do curso de Licenciatura em Educação Musical da UAB - UFSCar, oferecido na modalidade a distância. Tal curso é resultado de uma parceria da Universidade Federal de São Carlos com a Universidade Aberta do Brasil, um projeto do Ministério da Educação do Governo Federal, visando uma ampliação das oportunidades de educação superior no país. Na exposição da pesquisa, são detalhados os processos de planejamento, produção e oferecimento da disciplina, destacando a escolha de conteúdos, a elaboração de materiais pedagógicos, os sistemas de avaliação e controle de freqüência, e algumas das situações vivenciadas durante sua primeira oferta, no primeiro semestre de 2009 . O foco do trabalho é inicialmente dirigido para o desenvolvimento da educação a distância e das ferramentas que tornam possíveis os processos educacionais de música nessa área. São levantadas questões sobre a formatação de cursos formais de música e sobre aprendizagens informais, observando exemplos dos dois casos no universo da Internet. Considerando tópicos que lidam com recursos educacionais abertos, comunidades virtuais, compartilhamento de arquivos online, administração de conteúdos e atividades em ambientes virtuais de aprendizagem, e comunicações online com tutores e alunos, foi realizada a exploração de um vasto campo, encontrado em crescimento vertiginoso e constante modificação. Dentro desse cenário, o surgimento do curso de Licenciatura em Educação Musical da UAB - UFSCar representa um marco histórico, como uma das primeiras experiências acadêmicas a distância, em ampla escala, a contribuir para a formação de professores de música em instituições brasileiras. Ao aproximar o olhar desse projeto, a percussão serviu como laboratório para uma investigação de questões relacionadas ao ensino de instrumentos musicais, com seus desafios particulares que, tradicionalmente, foram enfrentados em situações face a face, em que professor e alunos dividem um mesmo espaço, presencialmente. A pesquisa busca avanços no sentido de que a educação musical possa utilizar plenamente as possibilidades que a educação a distância oferece, consolidando a interseção dessas duas áreas como prática social significativa no Brasil.

Palavras-chave: educação musical, educação a distância, percussão. 


\begin{abstract}
GOHN, Daniel M. Music distance education: proposals for teaching and learning percussion. 2009. Tese (doutorado). Escola de Comunicações e Artes, Universidade de São Paulo, São Paulo, 2009.

The goal of this thesis is to produce a study on music distance education. Taking the current scenario of music and technology as a starting point, with all the facilities and problems arose by the vast array of communicational possibilities of the modern world, this theme is developed having in sight the formation of music teachers. For such task, as part of the work the discipline "Percussion" was chosen as an object of analysis, after being created and developed within the course of Music Education at the UAB - UFSCar system, offered through distance education. This system results from a partnership between the Federal University of Sao Carlos and the Brazilian Open University, a project of the Ministry of Education of Brazil, aiming to increase opportunities for higher education in this country. At the exposition of the research, processes for the planning, preparing and offering of the discipline are detailed, showing contents chosen, elaboration of pedagogical materials, evaluation and frequency reports, and some of the situations experienced during its first offering, on the first semester of 2009. The focus of the work is initially set on distance education and on the tools that enable educational processes of music to occur within this area. Questions raised include formal programs of music and informal learning, observing examples for both cases on the Internet. Considering topics that deal with open educational resources, virtual communities, online file sharing, virtual learning environments, and online communications with tutors and students, a huge field was explored, one that is growing fast and constantly changing. As part of this context, the appearance of the course of Music Education at the Federal University of Sao Carlos sets a historic benchmark, being among the first academic experiences with distance education, in large scale, to contribute to the formation of music teachers in Brazilian institutions. Taking a closer look at this project, the discipline percussion served as a laboratory to investigate issues related to the teaching of musical instruments, with its own particular challenges, traditionally taken in face to face situations, when teacher and student share the same physical space. The research seeks to advance towards a music education that utilizes fully the possibilities that distance education offers, consolidating the intersection of these two areas as a significant social practice in Brazil.
\end{abstract}

Keywords: music education, distance education, percussion. 


\section{SUMÁRIO}

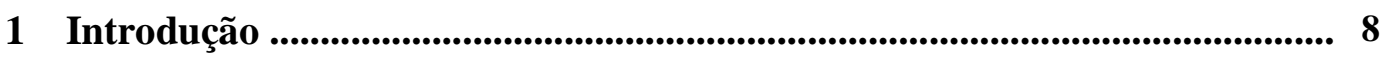

1.1 Entre a ficção e a realidade ............................................................................ 8

1.2 Contexto atual de tecnologia e música ......................................................... 14

1.3 Investigando o ensino a distância de percussão ............................................... 18

2 Educação a distância (EAD) ................................................................................ 26

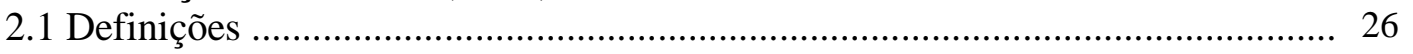

2.2 Histórico da EAD …………………………………………………..... 31

2.3 Universidade Aberta do Brasil ...................................................................... 37

3 Meios de comunicação musical ......................................................................... 41

3.1 Notação musical ......................................................................................... 43

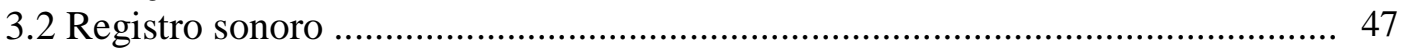

3.3 Tecnologias digitais ................................................................................... 52

3.4 Softwares educacionais e websites .................................................................. 56

4 Questões sobre música e EAD ........................................................................ 62

4.1 Informação e aprendizagem ......................................................................... 62

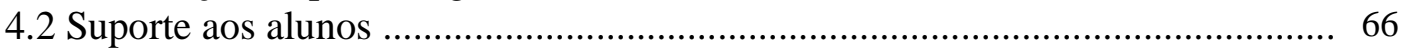

4.3 Comunidades virtuais ................................................................................. 71

4.4 Recursos educacionais abertos ..................................................................... 77

5 Para discutir a educação musical a distância ................................................. 84

5.1 Tipos de conhecimento ............................................................................ 84

5.2 Aprendizagem informal e EAD ................................................................... 88

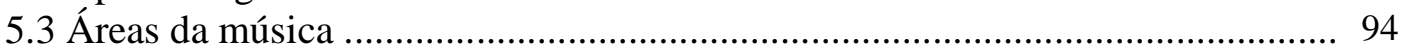

5.3.1 História da música ................................................................................ 96

5.3.2 Apreciação musical ............................................................................ 99

5.3.3 Treinamento auditivo e estudo de harmonia ............................................ 103

5.3.4 Composição …………………………………………………………... 106

5.3.5 Performance .......................................................................................... 109

6 Licenciatura em Educação Musical na UAB - UFSCar ................................. 115

6.1 A percussão na formação de professores de música a distância ......................... 115

6.2 Definição de conteúdos e elaboração de materiais pedagógicos ......................... 119

6.2.1 Exercícios com baquetas e com o pandeiro ……………………………….... 123

6.2.2 Atividades no ambiente virtual Moodle …………………………………... 126

6.2.3 Estrutura e funcionamento ......................................................................... 129

6.2.4 Avaliação e controle de frequiência ............................................................ 132 
7 Proposta de ensino a distância de percussão ................................................. 137

$\begin{array}{ll}7.1 \text { Resumo da disciplina } & 137\end{array}$

7.1.1 Unidade 1: Percussão e educação musical .................................................. 138

7.1.2 Unidade 2: Introdução à técnica de baquetas e ao pandeiro ........................ 140

7.1.3 Unidade 3: Rudimentos e samba no pandeiro ............................................ 143

7.1.4 Unidade 4: A percussão como ferramenta educacional ............................. 147

7.1.5 Unidade 5: Peça para caixa clara e baião no pandeiro .............................. 149

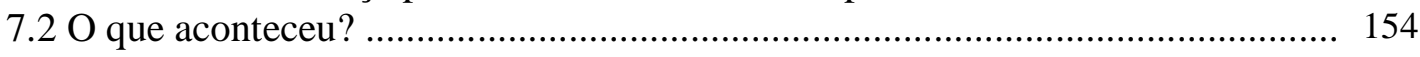

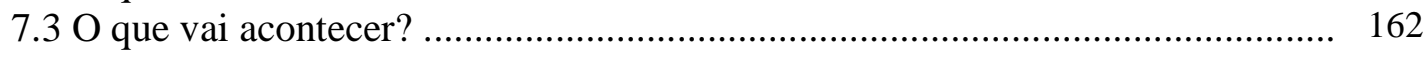

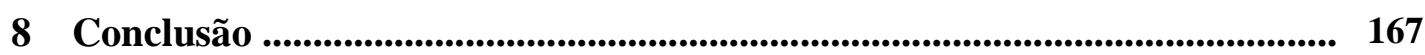

Referências bibliográficas ......................................................................... 174

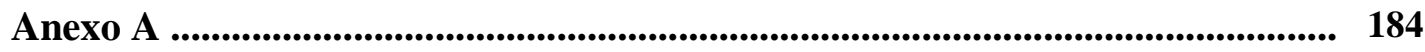

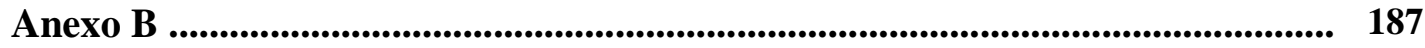

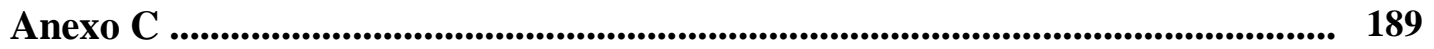




\section{Introdução}

\subsection{Entre a ficção e a realidade}

Em 1931, Aldous Leonard Huxley concluiu sua obra intitulada Brave New World, um romance futurista em que previsões amedrontadoras indicavam uma realidade turva e desprovida dos conceitos humanísticos existentes naquela terceira década do século XX. Permeando toda a situação, o desenvolvimento tecnológico era apontado como elemento essencial no controle sobre a vida dos indivíduos, desde a concepção destas vidas, passando pelas fases de crescimento e aprendizagem, até o destino que uma determinada "categoria" de ser humano deveria cumprir durante sua existência. Quinze anos após escrever o livro, Huxley redigiu um prefácio demonstrando alguns dos defeitos daquele trabalho, no entanto, sem fazer nenhuma menção de corrigi-los, pois caso contrário iria "se livrar não somente de algumas das falhas da estória, mas também de alguns dos méritos que ela originalmente possuía” (HUXLEY, 1989: viii). Os comentários colocavam a obra sob uma nova luz, em um momento marcado pela guerra e pelas mudanças que a fissão nuclear trazia ao mundo.

Em 1958, Aldous Huxley escreveu Brave New World Revisited, um exame detalhado das profecias que haviam sido concebidas no livro original. Fazendo comparações com a realidade da época, temas como superpopulação, substâncias químicas para induzir pessoas à felicidade, propaganda e liberdade, mostravam que aquelas profecias estavam acontecendo muito antes do que o autor esperava. Paralelos foram traçados com o livro 1984, de George Orwell, sob a sombra do Stalinismo e do Nazismo, e as projeções das duas obras foram equiparadas na análise do mundo político que se apresentava.

Hoje, quase oitenta anos após a publicação de Brave New World, é inevitável o assombro perante as várias similaridades entre a ficção e o que se pode observar na realidade presente. No referente à biologia, por exemplo, a idéia de fetos de características pré-determinadas gerados em laboratório antecedeu as atuais pesquisas sobre o DNA humano. São enormes as proximidades entre a imaginação privilegiada do autor inglês e os acontecimentos transcorridos muito tempo depois de sua existência.

Refletindo sobre a auto-análise de Huxley em 1958, é impossível não conjeturar o que o 
mesmo diria cinqüenta anos mais tarde, caso ainda estivesse vivo e ciente do histórico tecnológico ocorrido no planeta Terra. Sabendo-se que ele trabalhou um longo período como jornalista e crítico musical, fantasiar sobre suas visões do atual cenário que a tecnologia produz para a música é um convite para a pesquisa acadêmica. Um estímulo para ampliar a imaginação e propor usos diversificados para a estrutura das redes de computadores que se alastram velozmente no mundo moderno.

Brave New World não está sozinho em suas previsões tenebrosas. Centenas de outros títulos, como The Naked Sun, escrito por Isaac Asimov, e filmes como Blade Runner (do diretor Ridley Scott) e a série Matrix (dos diretores Andy e Larry Wachowski), também desenham perspectivas de um futuro em que a humanidade fica condicionada aos contornos dos avanços tecnológicos. O domínio da máquina sobre o homem é um tema recorrente e exerce um fascínio evidente sobre todos os artistas que se propuseram a forjar obras ambientadas no futuro. Daniel Dinello (2005) investigou o assunto no livro Tecnofobia, assinalando o "paraíso tecnológico" pregado pelos cientistas em contraste com as imagens negativistas desenhadas pela ficção científica. ${ }^{1}$

Como tema de obras literárias, a resistência à tecnologia não teve muito destaque até a publicação de Frankenstein $^{2}$, de Mary Shelley, em 1818. Mais tarde, as consequiências da revolução industrial, combinadas com o caos gerado pela Primeira Grande Guerra, reforçaram as visões da ficção tecnofóbica, dando origem ao filme Metropolis, de Fritz Lang (1926), e às adaptações para o cinema de Frankenstein, em 1931 e 1935. A situação prevista em tais obras indicava um caminho que foi concretizado com o surgimento da bomba atômica e dos campos de concentração nazistas, inegáveis demonstrações da aplicação da tecnologia com finalidades de domínio e exterminação. Como motto constante, as maravilhas conquistadas com descobertas tecnológicas trazem conseqüências desastrosas, agredindo o presente e ameaçando o futuro.

\footnotetext{
${ }^{1}$ Em seu estudo sobre a tecnofobia, Dinello (2005) analisou filmes, livros e jogos eletrônicos que colocam a tecnologia como ameaça, e marcou o "paraíso tecnológico" como conseqüência do trabalho de cientistas financiados pelas guerras e pelos lucros do mundo corporativo, mas adverte que "nem toda ficção científica é tecnofóbica e nem todos os cientistas servem aos interesses militares e corporativistas" (DINELLO, 2005: 7).

2 A imagem de Frankenstein é muito usada para indicar "colagens de pedaços bastante diferentes" ou "colagens monstruosas". McCutcheon (2007), por exemplo, se referiu a ela para representar tanto as tecnologias de produção (samplers) quanto de consumo (compartilhamento de arquivos digitais) da música. Com os samplers, é possível criar "monstros", feitos com a colagem de recortes sonoros; com os programas de compartilhamento de arquivos, temos uma ferramenta que ao mesmo tempo liberta (do controle das companhias gravadoras) e ameaça (os direitos autorais de compositores e intérpretes). Ou seja, esse autor coloca o "discurso moderno da tecnologia no capitalismo industrial (..) como um fetiche condicionado por Frankenstein” (MCCUTCHEON, 2007: 259).
} 
Em sua obsessão por cientistas loucos, robôs enfurecidos, clones assassinos, ciborgues estranguladores, andróides que odeiam humanos, supercomputadores satânicos, vírus devoradores de carne e monstros mutantes genéticos, a ficção científica expressa um medo tecnofóbico de perdermos nossa identidade humana, nossa liberdade, nossas emoções, nossos valores e nossas vidas para as máquinas. Como um vírus, a tecnologia autonomamente se insinua na vida humana e, para assegurar sua sobrevivência e dominação, malignamente manipula as mentes e os comportamentos dos humanos (DINELLO, 2005: 2).

Segundo Postman (1993), a origem da desconfiança tecnológica ocorreu juntamente com todos os inventos surgidos durante o século XIX, quando também surgiu "a idéia de que se algo poderia ser feito, deveria ser feito”. A crença no desenvolvimento tecnológico como resposta para todas as questões humanas veio acompanhada de uma valorização dos princípios que estimulam a invenção: objetividade, eficiência, expertise, padronização e progresso. Todas estas noções floresceram dentro de um contexto em que os indivíduos eram vistos não como filhos de Deus ou cidadãos, mas como consumidores. Tal idéia provocou diversas reações de autores citados por Postman (1993: 42), como William Blake, Matthew Arnold, Carlyle, Ruskin e William Morris, na Inglaterra; e Balzac, Flaubert e Zola, na França. O progresso industrial, na visão destes pensadores, trazia uma degradação espiritual, arrancando a alma dos homens e promovendo uma espiritualidade vazia, conduzida pela pobreza do impulso aquisitivo.

Na segunda década deste mesmo século, entre 1811 e 1816, o movimento ludita aparece como um marco na resistência à implementação de novas tecnologias na vida cotidiana (JONES, 2006). Na Inglaterra, um grupo de artesãos protestava contra as mudanças causadas pela revolução industrial destruindo máquinas de fabricação de tecidos, demonstrando o descontentamento gerado pelos cortes nos salários e pela eliminação de leis que protegiam a mão-de-obra especializada. Desde então, o termo "ludita", derivado do nome de Ned Ludd ${ }^{3}$, um dos inspiradores do movimento, passou a ser empregado de forma genérica para designar todos aqueles que se opõem ao progresso tecnológico.

Mais tarde, esta oposição ao desenfreado avanço científico encontrou refúgio na ficção científica. No entanto, se por um lado este gênero literário anunciava catástrofes, por outro

\footnotetext{
${ }^{3}$ A origem do termo Luddite é controversa. Segundo Postman (1993), há aqueles que afirmam que é uma referência a um jovem chamado Ludlum; Jones (2006) coloca que o nome surgiu a partir de Ned Ludd, mas que este é apenas uma figura inventada como um líder mitológico para o movimento ludita. Pynchon (1984) menciona um ataque de raiva de Ned Ludd que realmente teria acontecido em 1779, quando este destruiu duas máquinas de costura, recebendo após este fato o apelido de King Ludd ou Captain Ludd.
} 
incitou o homem a sonhar com grandes realizações. Muitos autores de obras futurísticas, embora com extraordinários acertos na antecipação do que estava por vir, não tiveram a oportunidade de ver a concretização de suas idealizações. Julio Verne, por exemplo, autor francês considerado precursor da ficção científica, escreveu diversos livros durante o século XIX em que imaginou máquinas do futuro, muitas das quais iriam existir na realidade. Em "Vinte Mil Léguas Submarinas", o Nautilus apresentava características avançadas, que fariam parte dos submarinos de verdade somente em épocas posteriores; em "Da Terra à Lua", um projétil era lançado ao espaço da Flórida, nos Estados Unidos, em um local situado a trinta quilômetros de onde, cem anos depois, realmente aconteceria a decolagem da espaçonave Apollo 11. Tamanhas "coincidências" indicam a capacidade humana em lançar um olhar para o futuro a partir da observação do presente.

Enquanto alguns escritores antecipavam em seus livros realidades ainda inexistentes, o também autor de ficção científica HG Wells viveu situações na prática, durante o século XIX, que hoje são temas da presente tese de doutoramento. Entre 1890 e 1893, ele trabalhava como tutor da University Correpondence College, em Londres, auxiliando estudantes da disciplina Biologia Elementar, quando disse: "eu carregava os livros de respostas de meus alunos por correspondência em ônibus e trens e os corrigia indo e voltando dos laboratórios na Red Lion Square" (citado em KenYON Jones, 2008: 171). Depois, Wells foi aluno do "sistema externo" da Universidade de Londres, obtendo o título de Doctor of Science em $1943^{4}$. Em sua autobiografia, o autor foi um crítico contundente do sistema por correspondência que era utilizado, mas fez a ressalva de que "era a única forma de conseguir uma rápida difusão do ensino. A qualidade tinha que vir mais tarde" (citado em KENYON JONES, 2008: 172).

No início do século XXI, o pesquisador acadêmico com intenção de investigar as possibilidades que as novas (e velhas) tecnologias podem abrir para a educação realiza, de certa forma, uma prática similar àquela exercida por autores de ficção científica. Mesmo que as finalidades estejam bem distantes, também há um esforço para integrar a tecnologia nas histórias, projetando maneiras que auxiliem os processos de ensino e aprendizagem. A principal diferença está no fato de que, ao invés de mostrar o criador subjugado pela criatura, como freqüentemente

\footnotetext{
${ }^{4}$ Outros alunos ilustres do sistema externo da Universidade de Londres foram Mahatma Gandhi, em 1890, e Nelson Mandela, em 1963. Anteriormente, Mandela já havia completado um bacharelado por correspondência pela University of South Africa, mas apesar de estudar durante a maior parte dos 27 anos em que esteve preso, as condições impostas pelas autoridades da África do Sul o impediram de terminar o curso na instituição londrina.
} 
fazem os escritores, o pesquisador deve imaginar um futuro em que o homem domine a máquina, usando-a para fins benéficos e mantendo eventuais efeitos colaterais sob um rígido controle de mensuração. Assim, são antevistas as situações que serão enfrentadas enquanto atitudes são tomadas de forma a promover os acontecimentos que interessam. É criado um universo ideal, para o qual se deseja ir, e são usados os equipamentos e sistemas disponíveis para se aproximar do destino imaginado. A imaginação serve como fonte de inspiração, de onde se colhe as imagens na tentativa de concretizá-las através de planos e realizações.

Na pesquisa acadêmica, como foi relatado por Litto (2003), há um campo de investigação definido como "estudos do futuro", com seus próprios métodos e ferramentas, suas publicações e congressos. Não há unanimidade se se trata de uma ciência ou de um movimento, ou mesmo se é apenas uma extensão de planejamento estratégico. Mas, embora muitos pesquisadores desta área considerem importantes os métodos "não-racionais" ou "não-analíticos", o espírito cético apresentado por eles, ao assumir que não existem regras invioláveis quando se observa o futuro, é compatível com as tarefas necessárias para buscas por conhecimento em todas as outras áreas. Afinal,

...o aumento de incerteza em muitos setores de investigação científica, a agregação e a desagregação provocadas pelo advento das novas tecnologias de informação, e o novo receio de 'conseqüências não-pretendidas' requerem um grau de modéstia do tipo exibido pelos futuristas (LITTO, 2003: 100).

$\mathrm{Na}$ atualidade, a tecnofobia ludita convive com o entusiasmo gerado pelas facilidades conquistadas dentro do universo digital. As visões que retratam as tecnologias modernas como o recurso salvador absoluto ou como o veneno corruptor do mundo como o conhecemos se encontram em meio a um dilema: deve-se abaixar a guarda e abraçar o que parece ser o futuro inevitável ou firmar a resistência e preservar os valores do passado?

O papel do pesquisador é encontrar o equilíbrio entre a empolgação com a criatura que ganha vida e o receio de conseqüências negativas com o seu surgimento. Dessa forma, buscando resultados concretos em suas ações, esse discurso moderno da tecnologia poderá soar realista e visionário, utilizando as invenções tecnológicas em toda a sua plenitude, mas sem perder a objetividade.

A fascinação do autor da presente pesquisa pela vida mergulhada na tecnologia começou 
com a leitura de livros de Isaac Asimov, no início da adolescência. O conceito de "distância" foi modificado naquele momento, pois em várias estórias os personagens jamais se encontravam pessoalmente, ficando a maior parte do tempo em suas residências. Contatos entre as pessoas eram realizados com o uso de holografias e a presença de outro ser humano produzia um acentuado grau de desconforto, sendo que apenas aquele escolhido para ser o parceiro conjugal era considerado aceitável. Embora tal situação represente um exagero da situação de hoje, os relacionamentos virtuais já são uma realidade constante, e casos de indivíduos que passam mais horas em frente ao computador do que conversando com outras pessoas face a face são comuns. Mesmo que o isolamento anunciado por Asimov não seja atraente, a perspectiva de contato com seres humanos sem sair de casa é muito interessante. Depois de chegar à idade adulta, conhecendo os problemas para deslocamentos dentro de uma grande cidade e lidando com agendas turbulentas, as facilidades proporcionadas pelas tecnologias de comunicação são ainda mais valorizadas. Por isso as motivações iniciais desse trabalho surgiram ali, ainda sem a consciência de que o termo "educação a distância" seria tão importante para a humanidade.

Investigar assuntos relacionados à tecnologia é como perseguir a própria sombra: quando se chega ao ponto intencionado, o objeto de interesse já está um pouco mais a frente. Trata-se de um universo de conhecimento em constante mutação. Portanto, de alguma maneira, existe uma relação entre Aldous Huxley e o autor da presente pesquisa (além do fato de que os dois nasceram no mesmo dia, 26 de julho). O esforço de ambos está focado no futuro, mas enquanto o escritor de ficção científica procurava criar romances memoráveis, neste trabalho o objetivo é buscar idéias para modificar o presente.

Para realizar tal pretensão, esta tese aponta caminhos possíveis e busca propostas alternativas, na esperança de auxiliar professores de música e outros interessados em educação. Como aponta Souza, embora ainda sejam poucos os investigadores envolvidos com a educação a distância no campo da música, “a área não está se privando de dar passos arrojados (...) e de sonhar com a educação musical a distância como uma outra forma significativa de prática social" (SOUZA, 2007: 389). Espera-se que esta contribuição represente mais alguns passos firmes e consistentes rumo à presença da música na EAD. 


\title{
1.2 Contexto atual de música e tecnologia
}

\begin{abstract}
... a música da era tecnológica, disponível e repetível a todo o momento, inscreve-se cada vez mais num continuum espaço-temporal, o da rádio aberta 24 sobre 24 horas. Toma-se então, facilmente, o aspecto não de um discurso articulado e acabado no tempo (contando uma história acabada), mas de um continuum semelhante a um continuum natural, que nunca começa nem acaba (CHION, 1994: 50).
\end{abstract}

Dentro do atual estágio de desenvolvimento tecnológico, é possível observar uma atividade crescente de troca de informações via rede de computadores. Sistemas permitem que máquinas separadas por grandes distâncias possam enviar entre si músicas digitalizadas, indivíduos disponibilizam seus discos para outros indivíduos que jamais irão conhecer pessoalmente, obras são adquiridas virtualmente e baixadas pela Internet. Avanços nas tecnologias de compressão reduziram o tamanho dos arquivos a transmitir, enquanto a largura de banda das conexões entre as máquinas aumentou a velocidade de transmissão de dados. A partir do final do século $\mathrm{XX}, \mathrm{o}$ ato de transmitir registros sonoros tornou-se rápido e descomplicado.

A comodidade e o baixo custo destas operações abrem possibilidades para contatos com novas músicas, com estilos antes desconhecidos, com diferentes ritmos e instrumentações, com músicos atuando fora do circuito de acesso usual dos indivíduos, ampliando seus universos artísticos. Como foi observado por Katz (2004), quem obtém músicas de forma gratuita na Internet sente-se livre para explorar gêneros musicais ainda não familiares, sem o risco de desperdiçar dinheiro ou tempo; se a música não agradar, basta apagar o arquivo. Comunidades virtuais reúnem milhões de pessoas que trocam opiniões sobre música, expondo críticas e elogios, trazendo indicações, resenhas, mostrando novidades e resgatando gravações do passado. As perspectivas para a educação musical são enormes e não devem ser desprezadas.

Assim como Aldous Huxley ou Julio Verne, os pesquisadores que hoje investigam os caminhos futuros da educação podem sonhar com tecnologias ainda inexistentes e supor algumas das mudanças que podem ocorrer em virtude delas. Todos devem estar preparados para essas tecnologias, não se deixando surpreender por usos indevidos e mantendo um passo à frente dos desafios que serão apresentados. Acompanhar a evolução das ferramentas que serão usadas é um sinal de bom senso, freqüentemente significando economia de esforço e sintonia com as gerações mais jovens. Obviamente, além de imaginar aquilo que está por vir, é possível utilizar o que já 
existe. As tecnologias atuais estão sendo cada vez mais aproveitadas na educação, especialmente na área da música. O amplo leque de novas práticas que estão se tornando usuais no cotidiano moderno, transformando o computador em peça central de sistemas para conhecer novas pessoas e receber informações e notícias, configura uma estrutura a ser observada e estudada em detalhes.

A disseminação de conteúdos na forma digital proporciona uma facilidade de acesso à música que tornará sua ubiqüidade inevitável, dando origem a um fluxo constante de produção musical ao alcance da maioria dos indivíduos, como acontece com a água (pelo menos nos países desenvolvidos ${ }^{5}$ ). O conceito de "música como água" (KUSEK e LEONHARD, 2005) tem como base a idéia de que se irá pagar pela música que é ouvida de forma parecida a que se paga pela água que é utilizada.

Na maioria das cidades modernas, são cobradas taxas para se ter água corrente nas residências, e isto representa um gasto usual, que se espera despender todos os meses. Em um restaurante, para lavar as mãos antes da refeição, exige-se que a torneira do lavatório tenha água, e não se paga diretamente pelo seu uso (talvez haja um pagamento indireto, com valores embutidos nos preços finais do consumo realizado). Eventualmente, em bares pode-se comprar água "de melhor qualidade", de marcas importadas conhecidas como Evian ou Perrier, e neste momento se paga mais por se tratar de um produto especializado, garantido contra bactérias, com uma embalagem prática, e que pode ter sido mantido refrigerado se assim for desejado.

Similarmente, serão cobradas taxas mensais baixas para ter acesso ao conteúdo musical de interesse, utilizando todos os mecanismos disponíveis para a individualização da experiência. Ou seja, haverá mais controle sobre a música que é ouvida, aceitando ou não as recomendações recebidas, e o valor cobrado pelo acesso a um enorme repositório de informações será relativamente pequeno. Ocasionalmente, poderão ser escolhidas músicas consideradas “especiais", talvez performances reservadas a um grupo seleto, ou a mais recente produção de um artista que é muito admirado. Nesse momento, como na compra de água Evian, será cobrado um valor mais alto.

\footnotetext{
${ }^{5}$ É importante ressaltar que a abundância de água implicada aqui está considerando a situação ainda constatada na maioria dos grandes centros urbanos no mundo, apesar da consciência mundial que existe sobre a falta de água em várias regiões, e das pesquisas prevendo o agravamento deste problema. Há, também, previsões sobre o acontecimento de guerras causadas pela disputa por territórios com acesso à água. A UN Water é o mecanismo das Nações Unidas para lidar com esta questão, e o website http://www.unwater.org apresenta uma série de dados alarmantes sobre o tema.
} 
A Internet é uma ferramenta poderosa na divulgação de conteúdo musical, sendo uma alternativa que oferece maior flexibilidade ao ouvinte se comparada aos meios existentes anteriormente, como o rádio. Uma simples busca através de palavras torna possível encontrar as obras procuradas, assim como permite a audição de um vasto acervo de músicas desconhecidas. Tal fato representa a continuidade da história iniciada com os primeiros registros sonoros ocorridos no final do século XIX, tornando possível levar a música até lugares onde nenhum músico jamais havia estado. Até o início do século $\mathrm{XX}$, um artista seria ouvido somente nos locais em que se apresentasse, mas a gravação sonora expandiu drasticamente este alcance. Dentro de uma realidade "música como água", há um salto brutal neste processo de expansão, pois o acesso torna-se simples e pouco dispendioso. Havendo uma captação do som e sua fixação em uma base física, o processo de digitalização sonora possibilita a produção e a disseminação de cópias perfeitas da obra musical, gerando custos extremamente baixos, facilitando sua circulação e tornado-a facilmente encontrável. Portanto, não é mais preciso comprar um disco ou gravar uma fita para ouvir música, pois se está sempre mergulhado em um continuum sonoro, cercado por todos os lados. Como consequiência, conclui-se que o "acesso vai substituir a posse. Afinal, se você pode ouvir o que quiser, quando quiser, não é preciso 'possuir' ou fisicamente adquirir a música” (KUSEK e LEONHARD, 2005: 4).

Com os diversos canais de fluxo informacional digitalizados, elevados a potência máxima depois da popularização da Internet, obter uma determinada informação já não significa um desafio tanto quanto em épocas passadas. Na realidade, o conhecimento freqüentemente é dado de graça, como indica Giving Knowledge for Free, um estudo publicado pela Organisation for Economic Co-operation and Development (OECD, 2007). Embora os conteúdos educacionais ainda sejam considerados um importante elemento de propriedade intelectual, muitas instituições de ensino e indivíduos estão disponibilizando seus materiais gratuitamente na Internet, como recursos educacionais abertos (ou open educational resources, OER). Como resultado, há uma aproximação entre os mundos de aprendizagem formal, não-formal e informal ${ }^{6}$, expandindo o

\footnotetext{
${ }^{6}$ A distinção entre a educação formal, a não-formal e a informal envolve diversas dimensões, sendo que uma das principais é a separação de seus campos de desenvolvimento. Segundo Gohn, M. (2008: 127), pode-se identificar a educação formal como aquela "desenvolvida nas escolas, com conteúdos previamente demarcados; a informal, como aquela que os indivíduos aprendem durante seu processo de socialização - na família, bairro, clube, amigos etc., carregada de valores e culturas próprias, de pertencimento e sentimentos herdados; e a educação não-formal é aquela que se aprende 'no mundo da vida', via os processos de compartilhamento de experiências, principalmente em espaços e ações coletivos cotidianas". Um elemento importante na diferenciação entre a educação não-formal e a informal é a intencionalidade: a não-formal é construída predominantemente por processos interativos intencionais.
} 
acesso à aprendizagem para todos, mas especialmente para aprendizes que não tiveram chance de estudar em instituições formais.

Como diz Litto (2006), o mundo passou da "cultura da escassez", na qual as pessoas acreditam que coisas boas sempre vêm em quantidades pequenas, como "ouro, diamantes, inteligência, e acesso ao conhecimento, freqüentemente contido em livros raros, disponíveis apenas para os mais ricos ou os estudiosos" (LITTO, 2006: 60); para uma "cultura de abundância", na qual disponibilizar o acesso aos acervos de objetos e manifestações culturais, técnicas e científicas é uma questão de justiça. Se possuir livros já foi indício de riqueza e poder no passado, hoje é mais importante saber selecionar as páginas certas e interpretá-las de acordo com diferentes contextos. Para isso, cada vez mais são essenciais os metadados, para identificar os crescentes repositórios de conteúdos na Internet; e o ajuste de informações às condições específicas de cada local, para que regiões menos desenvolvidas não assumam papéis de simples “consumidores" (OECD, 2007).

Portanto, "acesso" e senso crítico são palavras chave para a compreensão de novos processos de ensino e aprendizagem da música, a partir do convívio de aprendizes e educadores com as novas tecnologias. Tal situação fica evidente para os professores de música quando seus alunos ouvem repertórios variados sem gastar grandes quantias monetárias, estabelecendo contato com uma vastidão de conteúdos e encontrando caminhos de aprendizagem por diversas vias, misturando-as de acordo com seus gostos pessoais. Dentro de um contexto em que todo tipo de informação está disponível gratuitamente e se pode ouvir a música desejada, quando for desejada, o foco da atenção e o tempo despendido na escuta musical são extremamente valiosos. Há muito para ouvir e para ler, mas não há tempo suficiente para tudo. Aprender a pensar criticamente, refletir e julgar as opções disponíveis é uma das metas da educação, e a importância de tais capacidades nos tempos atuais é redobrada, tendo em vista a constante ampliação do universo digital.

Se a música pode unir grupos e gerar sentimentos de pertencimento a comunidades, as recentes tecnologias da comunicação facilitam a formação de agrupamentos com interesses comuns, criados em torno de um determinado estilo musical, um compositor ou um intérprete específico. O impacto desta facilitação fica evidente na observação das novas práticas sociais envolvendo salas de bate-papo, listas de discussão, fóruns, sistemas de compartilhamento de 
arquivos e websites construídos para gerenciar relacionamentos. Com a ampliação da conectividade da Internet, conquistada com aparelhos de grande mobilidade, como laptops, celulares e PDAs (personal digital assistants), é possível entrar em contato com o universo digital durante deslocamentos, quebrando definitivamente as barreiras físicas de acesso às comunidades virtuais e aos seus assuntos de interesse. Cada vez mais, os aparelhos eletrônicos são usados não somente como meio para chegar a informações, mas também para falar com outras pessoas, discutir, opinar, pedir conselhos e sugestões, buscar conforto e segurança.

Na obtenção de conteúdos e resolução de dúvidas sobre as mais diversas áreas do estudo musical, as possibilidades de uso do computador são cada vez mais comuns. A Internet dá origem ao que se pode intitular "aprendizagem musical como água", ou seja, as oportunidades de aprender música são tão comuns como os encanamentos em que se encontra água. Com isso, surgem expectativas de respostas rápidas para qualquer questão, a partir de procedimentos simples, como uma busca no Google. Se essa perspectiva é animadora e enche muitas pessoas com entusiasmo, há que se observar e analisar as conseqüências de tanta facilidade, para evitar que com a comodidade venha o comodismo, e que apareça uma espécie de fast-food educacional, prometendo atalhos milagrosos e irreais no estudo da música.

No presente trabalho, foi feito um recorte desse atual contexto de música e tecnologia na educação: uma pesquisa sobre ensino e aprendizagem de percussão a distância, tendo como objeto central um curso de formação de professores de música.

\subsection{Investigando o ensino a distância de percussão}

A pesquisa apresentada nesta tese consistiu na realização de um estudo sobre educação musical a distância, na elaboração de uma proposta de disciplina de percussão, e na aplicação desta proposta dentro de um curso de formação de professores de música. O trabalho foi realizado no âmbito de um curso de Licenciatura em Educação Musical, lidando com a questão de forma direta: organizando conteúdos e propondo metodologias de ensino para vencer os obstáculos encontrados. Portanto, durante a elaboração da tese, aconteceram experimentos com o tema em análise, em um formato de pesquisa-ação que "exige que o investigador abandone o lugar supostamente desinteressado do cientista, para se envolver, com o consentimento explícito 
dos participantes, nos processos de planejamento e implementação de uma intervenção no seu trabalho" (ADELMAN e KEMP, 1995: 113).

Dentro do processo de ser professor e pesquisador ao mesmo tempo, o desenvolvimento das atividades revelou tópicos que se tornaram categorias de análise do curso, conforme será apresentado no capítulo 7. As categorias selecionadas são as seguintes: críticas e elogios, falhas na organização, problemas musculares, assuntos abordados nos fóruns, flexibilização dos períodos de entrega das tarefas, dúvidas de tutores nas avaliações, e resultados das performances. Como conseqüência do primeiro oferecimento da disciplina, foram planejadas modificações nos conteúdos e nos encontros presenciais, e uma maior integração com outras disciplinas do curso.

O surgimento destas categorias ocorreu durante a oferta da disciplina, a partir dos acontecimentos observados nas interações entre professor, tutores e alunos. A alternância dos papéis de professor e pesquisador, assim como as trocas contínuas de softwares que comumente são utilizados nos computadores, gerou reavaliações e reflexões constantes sobre os próximos passos a seguir. Para a apresentação dos resultados, optou-se por um formato sintético, com a análise das reações dos alunos aos materiais preparados e às atividades propostas, chegando diretamente nas conclusões.

O modelo adotado remete à pesquisa-ação de inspiração lewiniana ou neolewiniana ${ }^{7}$, na qual há a elaboração de um paradigma de ação que seja aplicável em seguida em larga escala. Na construção de uma disciplina, de certa forma, as primeiras turmas funcionam como grupo-piloto, ou grupo-experimental. Com elas, os maiores ajustes são feitos, para que posteriormente um processo de ajustes finos seja realizado, sempre que se fizerem necessários. Nesse caso, como diz Barbier (2002: 41), “os riscos reais, porque estamos num campo real e não num laboratório, são limitados e controlados". A pesquisa-ação tem sido usada em muitas investigações sobre educação musical, tendo como foco uma ampla variedade de assuntos específicos (CAIN, 2008). Tais trabalhos "integram pesquisa e ação, são colaborativos, fundamentados em um corpo de conhecimentos existente, e resultam em aprendizagens significativas para os participantes" (CAIN, 2008: 309). Espera-se que os resultados da experiência aqui apresentada sejam úteis não somente para a percussão, mas também para o ensino a distância de outros tipos de instrumentos musicais e de outras áreas da educação musical.

\footnotetext{
7 Segundo Barbier (2002: 27), “costuma-se geralmente sustentar que a pesquisa-ação teve origem com Kurt Lewin, psicólogo de origem alemã, naturalizado americano, durante a provação da Segunda Guerra Mundial”.
} 
O momento de realização desse doutorado coincide com o período de início das atividades da Universidade Aberta do Brasil (UAB), um marco para a história da educação a distância no país. Logo no primeiro ano de funcionamento da UAB, uma parceria com a Universidade Federal de São Carlos (UFSCar) originou um curso de Licenciatura em Educação Musical (http://zope.ufscar.br:8080/edmus), resultante de um projeto que o autor dessa pesquisa ajudou a formular enquanto professor na UFSCar. Esse curso serviu como campo de investigações para a tese e deu exemplos das possibilidades que a modalidade a distância pode oferecer a serviço da educação musical. Tal oportunidade foi extremamente apreciada e valorizada, por permitir que as diversas equipes envolvidas em um projeto de educação a distância tomassem parte na disciplina Percussão, viabilizando a concretização do presente trabalho.

Simultaneamente à UFSCar, duas outras instituições exploram o terreno dos cursos de licenciatura a distância na educação musical: a Universidade de Brasília (UnB), que também se juntou à UAB (http://uab.unb.br); e a Universidade Federal do Rio Grande do Sul (UFRGS), que organizou um consórcio com seis outras instituições públicas ${ }^{8}$ (http://prolicenmus.ufrgs.br). Em outubro de 2009, durante o XVIII Congresso da Associação Brasileira de Educação Musical (ABEM), um painel de discussões reuniu os coordenadores destes três cursos, aprofundando as trocas de relatos de sucessos e de problemas. No mesmo evento, foi anunciado que o curso organizado pela UFRGS também está sendo integrado ao sistema UAB, com a devida adaptação aos formatos que já são utilizados pela UFSCar e pela UnB.

Como afirma Souza (2007: 389), no campo musical ainda não há "uma experiência acumulada na área de educação a distância para enfrentar os desafios culturais, políticos, financeiros e tecnológicos" que se apresentam. Assim, inúmeras questões certamente irão surgir como pontos de interrogação no caminho de professores e pesquisadores envolvidos nos projetos citados acima, provocando inquietações e discórdias. É essencial que os debates entre os seus coordenadores e demais participantes continuem, divulgando para a sociedade os avanços alcançados com os cursos que estão em funcionamento.

Se o ensino a distância de música ainda não solidificou consensos entre os pesquisadores acadêmicos, por outro lado, a afirmação de que o acesso a vários tipos de música está sendo facilitado pelas tecnologias dificilmente poderia ser contestada, visto o número de pessoas que

\footnotetext{
${ }^{8}$ As instituições parceiras são a Universidade Federal da Bahia, a Universidade Federal do Espírito Santo, a Universidade do Estado de Santa Catarina, a Universidade Federal de Mato Grosso, a Universidade Federal de Alagoas e a Fundação Federal de Rondônia.
} 
utilizam serviços de compartilhamento de dados para trocar músicas online. O primeiro sistema a chamar atenção foi o Napster, chegando a contar com 13.6 milhões de usuários em 2001, somente nos Estados Unidos (COLEMAN, 2003: 178). Em 2008, o software LimeWire, um dentre vários disponíveis na Internet, teve entre 80 e 100 milhões de usuários regulares. ${ }^{9}$ Mas diversas questões permanecem abertas para debates quando esse novo contexto de música e tecnologia é direcionado para processos de educação musical. De que formas a expansão de informações circulando nas redes de computadores poderá contribuir para aprendizagens mais significativas? Para lidar com essa pergunta, os cinco sentidos para o termo "educação musical", elaborados por David Elliot (1995: 12-13), podem ser úteis:

1) A educação em música envolve o ensino e a aprendizagem de fazer música e de ouvir música;

2) A educação sobre música envolve ensino e aprendizagem de conhecimento formal (ou informação verbal) sobre diversos aspectos da música, como performance, teoria, história da música e percepção;

3) A educação para a música envolve ensino e aprendizagem como uma preparação para uma carreira de instrumentista, compositor, historiador, crítico, pesquisador ou professor;

4) A educação por meio da música se mistura com os três primeiros sentidos, quando são direcionados para melhorar a saúde, a mente ou a alma de alguém;

5) A educação musical como "empreendimento profissional" ocorre quando alguém procura se credenciar para trabalhar como educador musical, podendo assim ganhar o seu sustento.

Como será colocado ao longo desse trabalho, a educação a distância pode contribuir para processos de educação musical em todos os sentidos acima, e os cinco significados para o termo são relacionáveis com a proposta do curso de Licenciatura em Educação Musical da UAB UFSCar. Observando o desenvolvimento desse curso, a pesquisa teve como meta trabalhar com conhecimento em, sobre, para, e por meio da música, para formar professores com critérios para escolher caminhos viáveis nas situações educacionais em que forem atuar.

\footnotetext{
${ }^{9}$ Dado colhido no blog da revista Wired (http://www.wired.com).
} 
Considerando as complexidades implicadas nos cinco sentidos, há diversos possíveis objetivos para processos de ensino e aprendizagem musical. Na disciplina denominada Percussão, que será observada no contexto do sistema UAB - UFSCar, pode-se destacar a formação em percussão, ao estudar os movimentos envolvidos no ato de tocar os instrumentos e ao diferenciar os variados estilos de percussão; os estudos sobre percussão, englobando verbalmente aspectos históricos, teóricos e de percepção; a educação para a percussão, como um incentivo aos indivíduos que decidirem seguir uma carreira de instrumentista, historiador ou pesquisador que esteja relacionada com essa área; a educação por meio da percussão, quando tocar e ouvir os instrumentos resultar em efeitos positivos para a saúde e o bem-estar de pessoas; e a percussão como um elemento da formação profissional do professor de música, buscando aperfeiçoamento e qualificação para a docência.

No cotidiano de grande parte dos indivíduos na atualidade, observam-se exemplos em que, seja de forma isolada ou em complementação a outros meios, o acesso à Internet contribui para tais formas de educação. Movido por mera curiosidade ou por trabalhos relacionados a programas de estudo estruturados, o aprendiz que navega na rede de computadores está vasculhando acervos espalhados por várias partes do mundo, acessando conteúdos também disponíveis por outros meios (como músicas que estão em CDs e textos que estão em livros) ou não (como reflexões encontradas em listas de discussão online). As tecnologias, nas palavras de McLuhan (1964), agem como extensões do homem, colocando-o em contato com esses conteúdos dispersos, e assim ocorre uma centralização de suas investigações a partir de mecanismos digitais.

São exemplos de situações que um estudante de percussão poderá vivenciar online: pesquisas sobre a origem e os materiais empregados na construção de um determinado instrumento, buscas de lojas ou indivíduos que estejam vendendo esse instrumento, vídeos de performances e de exercícios para instrumentistas, cursos formais e informais, materiais didáticos para aprendizagens diversas, comunicações com pessoas que tocam, ensinam, pesquisam, constroem, reformam, ou simplesmente gostam desses instrumentos. Toda essa amplitude de informações irá manter os estudantes mais informados, ajudando-os a explorar o universo da percussão e a realizar escolhas dentro dele.

Na disciplina observada na UAB - UFSCar, o ensino visa oferecer formação para o 
trabalho de professor de música, considerando possíveis situações em que o profissional ministra aulas utilizando a percussão, seja falando sobre instrumentos ou ensinando a tocá-los, ou tocando esses instrumentos para auxiliar outras atividades, como um pandeiro que acompanha a música de uma brincadeira de roda. Portanto, nesta pesquisa, sempre que se falar de "aluno", trata-se de um professor em especialização, que, por sua vez, já tem ou terá seus próprios alunos. Seria também viável o uso do termo "futuro professor", pois o diploma do curso de licenciatura oficializa essa profissão, mas é importante lembrar que muitos alunos podem já atuar como professores em diversos cenários educacionais.

Dentre as várias disciplinas que fazem parte da formação de professores, em cursos a distância, há uma grande demanda por soluções inovadoras naquelas relacionadas às questões da prática musical, envolvendo a performance com instrumentos musicais. Como lidar com os aspectos procedimentais específicos de cada instrumento, que usualmente são demonstrados na presença do aluno, com exemplos repetidos de diversas formas, em vários andamentos e observados a partir de diferentes ângulos de visão? Tal questionamento surge como elemento propulsor da hipótese que se pretende comprovar nessa pesquisa:

- O ensino a distância pode ser utilizado eficientemente em uma disciplina de percussão, dentro de um programa de formação de educadores musicais.

Partindo dessa afirmação, algumas questões se mostraram relevantes:

- Que aspectos da percussão (conhecimentos formais e procedimentais) devem ser priorizados na formação de professores de música?

- Como as tecnologias disponíveis devem ser utilizadas?

- Que tipos de interações entre alunos, tutores, professor e conteúdos devem ser valorizadas?

- Como deve ser a avaliação do desempenho dos alunos nessa disciplina?

Para buscar a confirmação dessa hipótese e encontrar respostas para as demais questões, a investigação ocorre em um campo pouco explorado, que ainda apresenta pouca literatura 
científica. Observa-se que as raras pesquisas na educação musical a distância estão embasadas em dois campos distintos: a educação a distância e a educação musical, existindo pouco material que trata dos dois assuntos simultaneamente. Essas duas áreas têm apresentado um crescimento relevante em anos recentes, com um avanço na quantidade de investigadores envolvidos, especialmente na EAD. No momento em que essa tese começou a ser produzida, foi apresentado um catálogo ${ }^{10}$ de quase 1000 produções acadêmicas, fazendo um mapeamento da educação a distância no Brasil. Certamente esse número irá aumentar bastante a partir desse instante, visto o surgimento da Universidade Aberta do Brasil e a expansão da área de forma geral.

Quando o tema específico da educação musical a distância foi objeto de investigação, as experiências mostraram-se promissoras e frutíferas. Por exemplo, ao trabalhar com professores das séries iniciais do ensino fundamental ${ }^{11}$, Souza oferece a seguinte resposta para a pergunta "pode a EAD ser usada na formação musical de professores?":

Certamente que sim. Os professores possuem um saber sobre o ato de aprender e estão ligados ao processo de ensino por definição de sua atividade de formação. Eles, mais do que qualquer outro grupo profissional, devem saber da importância das ações educativas coletivas como participantes do processo de transformação social e das mudanças que ocorrem quando se investe na própria formação (SOUZA, 2003: 14-15).

Sem dúvida, ter como alunos indivíduos envolvidos com a atividade pedagógica é um fator importante, pois assegura um compromisso com o ato e com o desejo de aprender. Outro aspecto a destacar é que, nesse trabalho de ensino a distância de percussão, não há aprendizes sem formação musical. Para que sejam admitidos no curso, os alunos da Licenciatura em Educação Musical da UAB - UFSCar passam por uma prova específica de conhecimentos musicais, durante o exame vestibular. Sendo assim, todos possuem experiências anteriores com o aprendizado da música, o que assegura que estes alunos de percussão foram estudantes de outros instrumentos no passado (se já não tiverem estudado a própria percussão antes), e são conhecedores dos caminhos e desafios na aprendizagem de um instrumento musical.

\footnotetext{
${ }^{10}$ O Anuário Brasileiro Estatístico de Educação Aberta e a Distância (ABRAEAD) de 2008 apresentou um estudo com 939 produções acadêmicas sobre a EAD no Brasil. Esses trabalhos foram defendidos em 30 instituições de ensino, no período de 1999 a 2007, sendo 762 dissertações de mestrado e 177 teses de doutorado (ABED, 2008).

${ }^{11}$ Em sua pesquisa de doutorado, Souza (2003) trabalhou com as quatro primeiras séries do ensino fundamental no Estado de Mato Grosso, capacitando professores para trabalhar com música, dentro de um projeto organizado pelo Núcleo de Educação Aberta e a Distância (NEAD) da Universidade Federal do Mato Grosso (UFMT).
} 
Para a exposição da pesquisa realizada, a tese de doutorado se divide em 8 capítulos. Após essa introdução, com uma visão geral de música, educação e tecnologia na atualidade, no capítulo 2 há um histórico da educação a distância, precedido por uma organização dos termos que são utilizados para definir a área. Culminando com o surgimento da Universidade Aberta do Brasil, essa parte do trabalho prepara o capítulo 3, no qual é investigado o desenvolvimento das tecnologias que possibilitaram a educação musical a distância. Intitulado "Meios de comunicação musical", este capítulo discute notação musical, registro sonoro, tecnologias digitais, softwares educacionais e websites como elementos que viabilizaram o curso de Licenciatura em Educação Musical da UAB - UFSCar.

No capítulo 4, são levantadas questões da EAD que se mostram pertinentes à educação musical, relacionadas ao apoio para o aluno que torna um curso a distância possível, e a dois assuntos atuais na Internet: as comunidades virtuais e os recursos educacionais abertos. No capítulo seguinte, o tema educação musical a distância é desmembrado em sub-temas, tratando dos tipos de conhecimento musical, de aprendizagens informais e de algumas das áreas do estudo musical (história da música, apreciação musical, treinamento auditivo, estudo de harmonia, composição e performance).

Finalmente, nos capítulos 6 e 7, é apresentada a proposta da disciplina Percussão, como parte integrante obrigatória do curso de Licenciatura em Educação Musical da UAB - UFSCar. No capítulo 6, há explicações sobre o processo de escolha dos conteúdos e da elaboração dos materiais pedagógicos, com informações sobre a estrutura, o funcionamento e o sistema de avaliação da disciplina. O capítulo 7 traz um resumo das unidades elaboradas para o curso e, em seguida, apresenta algumas das reações iniciais obtidas, considerando a participação de alunos, tutores virtuais e presenciais, e os ajustes que serão realizados a partir desses primeiros resultados.

Concluindo a pesquisa, as considerações finais do capítulo 8 relacionam questões encontradas até o capítulo 5 com as experiências relatadas nos capítulos 6 e 7. Os anexos ao final do trabalho servem para aprofundar a descrição da proposta da disciplina e do curso de que ela faz parte. Detalhamentos dos conteúdos abordados e das atividades programadas são encontrados no livreto que acompanha a tese, tendo esse material sido distribuído aos alunos, como recurso impresso para os estudos de percussão. 


\section{Educação a distância}

Com o intuito de preparar uma investigação sobre a educação musical a distância, foi realizado neste capítulo um breve histórico mapeando o desenvolvimento da $\mathrm{EAD}$, mesclando a evolução tecnológica e o surgimento de instituições importantes para o crescimento da educação a distância no mundo. Não serão aprofundadas as análises das tecnologias disponíveis para a EAD, pois já existe uma vasta literatura com pesquisas sobre este assunto (pode-se citar como exemplo Moore e KeARSLey, 2007; e BAteS, 1995). Mas anteriormente ao olhar sobre o caminho traçado até o momento presente, é importante analisar as terminologias comumente usadas no assunto, buscando identificar quais são as palavras que servirão para descrever situações específicas dentro do objeto de estudo.

\subsection{Definições}

As palavras "educação a distância" receberam enorme atenção em anos recentes, principalmente em virtude da expansão de cursos em que são constatados elementos identificados como pertencentes a este campo. Hilary Perraton colocou sua definição de educação a distância como "um processo educacional no qual uma parte significativa do ensino é dirigido por alguém distante no espaço e/ou no tempo do aprendiz"12 (PERRATON, 2000: 13). Michael Moore e Greg Kearsley apresentam um conceito mais amplo:

Educação a distância é o aprendizado planejado que ocorre normalmente em um lugar diferente do local do ensino, exigindo técnicas especiais de criação do curso e de instrução, comunicação por meio de várias tecnologias e disposições organizacionais e administrativas especiais (MOORE e KEARSLEY, 2007: 2).

Tais enunciados são suficientemente genéricos para incluir uma ampla variedade de circunstâncias que serão contempladas neste trabalho, mas também específicas bastantes para gerar questões de interesse, deixando evidente a idéia de que não se trata de um sistema presencial de ensino. Assim sendo, podem ser adotados como referência. No entanto, diversos outros termos são utilizados para nomear processos educacionais diferentes dos chamados

\footnotetext{
${ }^{12}$ Original em inglês: an education process in which a significant proportion of the teaching is conducted by someone removed in space and/or time from the learner (PERRATON, 2000: 13).
} 
sistemas face a face, formatos em que alunos e professores se encontram no mesmo espaço físico. Com isso, há confusões terminológicas que dificultam a compreensão das possibilidades existentes, tornando mais complexa a questão de definições da EAD.

Mason e Rennie (2006) mencionam o conflito entre as várias utilizações para determinadas palavras e propõem um quadro bastante esclarecedor sobre o assunto, indicando duas modalidades principais: educação a distância e educação face a face. Dentro da EAD, as palavras aprendizagem online, elearning (aprendizagem eletrônica), sala de aula virtual e aprendizagem via Internet são usualmente utilizadas para designar as redes de computadores como meio de contato entre o aluno e o material educacional. Unindo as duas modalidades principais, o termo aprendizagem híbrida (blended learning) indica aqueles processos em que existe uma combinação de contatos face a face e educação a distância, com possíveis alternâncias entre tecnologias síncronas e assíncronas e diferentes locais de onde os recursos pedagógicos são acessados. Englobando todas as colocações acima, o uso de "educação distribuída" serve para uma variedade de circunstâncias, implicando um conceito em que materiais educacionais são distribuídos por uma vasta área geográfica, utilizando alguma forma de aprendizagem híbrida com diferentes meios de comunicação entre professores e alunos.

Embora em certas situações as terminologias citadas sejam intercambiáveis, nota-se freqüentemente a utilização de elearning como sinônimo de educação a distância. No entanto, algumas definições de elearning referem-se somente ao uso da Internet para criar acesso ao conteúdo educacional, enquanto outras incluem o uso de CD-ROM, gravações de áudio e vídeo, transmissões via satélite, entre as demais alternativas ligadas à aprendizagem eletrônica. Não apenas as ferramentas eletrônicas são consideradas como meios para a educação a distância, pois além do computador, do rádio e da televisão, também os conteúdos impressos, enviados por correspondência, ainda têm grande importância.

Outros termos comumente associados à educação a distância são aprendizagem autodirigida, aprendizagem centrada no aluno, aprendizagem independente e aprendizagem autônoma, todos indicando a responsabilidade conferida aos aprendizes a partir das novas formas de aprender. A distância entre professor e aluno a que "educação a distância" faz referência pode ocorrer sem que o segundo jamais tenha contato com o primeiro. Nesses casos, a avaliação pode ser realizada pelo próprio aluno, sendo que muitas vezes não há currículos estabelecidos e não há 
a emissão de certificados. E mesmo quando ocorrem comunicações constantes entre professor e aluno, em processos a distância a responsabilidade sobre o andamento dos estudos é maior para o aprendiz, já que a maior parte das atividades pode não ter supervisão presencial e uma forte disciplina para evitar um acúmulo de conteúdos é necessária.

Como Bates (1995) aponta, tanto alunos de formatos presenciais quanto aqueles de educação a distância realizam a maior parte de seus estudos sozinhos, interagindo com textos, livros ou outras mídias de aprendizagem. A diferença é que, para os estudantes a distância, a preparação dos materiais é feita visando a maior quantidade possível de momentos de interação, na tentativa de simular uma conversação face a face entre professor e aluno. Esta conversa é conduzida por meio da interatividade entre aprendiz e materiais pedagógicos, e não depende necessariamente da intervenção de um tutor humano. Portanto, muitas vezes constata-se a "solidão do aprendiz a distância" (BATES, 1995: 52).

Mason e Rennie (2006: xvi) observam que "educação a distância" refere-se a um método, e não a uma filosofia de educação. A "aprendizagem aberta"13, por outro lado, é definida como uma filosofia que valoriza oportunidades para várias formas de engajamento com o processo educacional, como meio de remover barreiras no aprendizado. Ou seja, como afirmam Moore e Kearsley (2007), o termo "aberto" está relacionado com uma opção política, buscando minimizar impedimentos e tornar a educação mais acessível e menos elitista. A maioria das universidades abertas adere aos mesmos princípios: qualquer pessoa pode se matricular na maioria dos cursos, independente da educação anterior; professor e aluno poderão estar em localidades diferentes, em casa, no trabalho ou em qualquer outro local; uma variedade de tecnologias poderá ser utilizada para mediar as comunicações que acontecem tanto a distância como em situações presenciais; e o objetivo é atender um grande número de alunos, com grandes investimentos para assegurar uma qualidade elevada.

Conforme o que Bates (1995: 27) afirma, apesar de ser freqüente o uso das expressões "educação a distância" e "aprendizagem aberta" com o mesmo significado, há diferenças importantes: aprendizagem aberta é um objetivo, buscando flexibilizar a educação em torno das restrições geográficas, sociais e temporais dos aprendizes, e não daquelas de uma instituição de ensino; educação a distância é um meio para atingir uma finalidade, em que o aluno possa

\footnotetext{
${ }^{13}$ Enquanto "aprendizagem aberta" é um termo amplamente utilizado no Reino Unido, outros países preferem “aprendizagem flexível”, como acontece na Austrália (MASON e RENNIE, 2006: 88).
} 
estudar sem a necessidade de contato presencial com o professor, em seu ritmo próprio e no local de sua escolha. Existem cursos realizados a distância que apresentam uma série de exigências e restrições para que se participe deles, assim como há cursos presenciais que visam uma facilidade de acesso. Portanto, “existem programas de educação a distância que não são 'abertos', do mesmo modo que há programas de educação face a face que são" (MoORE e KEARSLEY, 2007: 3).

Partindo dos conceitos estabelecidos acima, no presente trabalho é considerada como educação musical a distância a situação em que um aprendiz interage com materiais pedagógicos planejados por um professor, que na maior parte do tempo do estudo não se encontra face a face com o aluno. A presença física do professor pode ocorrer em momentos presenciais préestabelecidos dentro de um curso programado para acontecer a distância; ou quando trata-se de cursos presenciais que utilizam recursos da EAD como complemento para atividades de sala de aula; ou pode simplesmente não ocorrer, caso o curso ofereça somente contatos via meios tecnológicos, ou se o programa de estudos é direcionado para uma completa autonomia do estudante.

Com a definição acima, o indivíduo que escuta um programa de rádio e recebe informações sobre um determinado compositor e suas obras está participando de um processo educacional, mesmo sem a continuidade com uma seqüência curricular e sem avaliações sobre os conteúdos apreendidos. Da mesma forma, ouvir gravações ou assistir vídeos com músicas pode ser enquadrado como educação a distância. Definir o que é considerado como educação musical é caminhar sobre uma linha tênue, pois esta tarefa implica em escolhas e prioridades na seleção de conteúdos, seja por parte do aprendiz ou do professor, sendo que este mesmo desafio ocorre na educação a distância e em formatos presenciais.

Portanto, na educação musical a distância sempre existe a figura de um aprendiz em contato com materiais preparados por um professor, mesmo que este último não supervisione o processo de interação. Há uma intencionalidade educacional no momento de criação dos conteúdos, quando o professor planeja os materiais; ou no momento em que o aprendiz estuda e decodifica os elementos demonstrados na prática por um intérprete, por meio do registro físico de sua expressão artística. Ou seja, a intenção de educar pode partir de um professor ou do próprio aluno, quando este direciona sua atenção e realiza reflexões sobre os variados tipos de conhecimento musical. 
Um exemplo deste segundo caso é uma performance registrada em vídeo, que pode ser assistida repetidas vezes, criando oportunidades para o desenvolvimento de técnica instrumental, conhecimento de repertório, orquestração de arranjos, entre outros tópicos. Assim, em um concerto gravado, cada um dos instrumentistas participantes poderá atuar como um mestre, pois as imagens e a música apresentada oferecem possibilidades de aprendizagens aos espectadores.

A figura do aluno poderá estar presente em três diferentes cenários: em aprendizagens autodirigidas, híbridas ou reguladas por cursos programados. As alternativas tecnológicas para auto-aprendizagens são cada vez mais amplas, principalmente com os diversos recursos disponíveis para a interação entre aprendizes e materiais educacionais (GoHN, 2003). Outra ocorrência comum é verificada com alunos de professores particulares, tendo aulas regulares de instrumentos musicais, que complementam seus estudos com pesquisas na Internet e em DVDs; e nos cursos presenciais formais, realizados face a face em escolas e universidades, quando os alunos buscam aprendizagens via interações a distância, fora dos horários delimitados para encontros nas salas de aula. Nesse sentido, todo processo educacional presencial envolve aprendizagens híbridas, pois o atual contexto de tecnologia e música, descrito na introdução da tese, coloca uma vasta lista de oportunidades para que aprendizes estudem também a distância.

O terceiro e último cenário é aquele desenhado pelos cursos formatados especificamente para acontecerem a distância, a partir de conteúdos preparados por professores especialistas e da supervisão de tutores, que poderão prestar auxílio aos alunos presencialmente ou via meios de comunicação. Este caso será o foco da tese de doutoramento aqui apresentada. O eixo que regula este trabalho de pesquisa, dentro da definição de Moore e Kearsley (2007), está nas "técnicas especiais de criação do curso e instrução". Sendo o assunto do curso proposto a música, mais especificamente o estudo de instrumentos de percussão, são enfrentados desafios em que, nas situações de aprendizagens presenciais ou híbridas, o professor usualmente utiliza muitas demonstrações práticas. Como os encontros entre tutores e alunos no curso analisado são raros e em grande parte são mediados tecnologicamente, a preparação dos conteúdos exigiu soluções específicas, buscando valorizar também as oportunidades para as aprendizagens autodirigidas dos estudantes.

Todos os exemplos citados, utilizando o rádio, o DVD ou outros meios, constroem possibilidades de educação distribuída, assegurando que, de alguma forma, seja em processos 
face a face ou a distância, conteúdos educacionais chegarão até um grande número de estudantes. A seguir, visando criar embasamento para a investigação sobre o tema específico da pesquisa, é apresentado um histórico do desenvolvimento da EAD.

\subsection{Histórico da EAD}

Alguns pesquisadores consideram o ensino a distância como sendo muito antigo, tendo início por volta do ano 50 da era cristã. Pfromm Netto (2001), por exemplo, indica Paulo de Tarso como um de seus precursores, em esforços para propagar o cristianismo. Nas primeiras comunidades cristãs, as leituras públicas das lições de São Paulo serviram como veículo fundamental para ampliar a fé em Jesus Cristo, respondendo a muitas indagações e auxiliando os novos fiéis a lidar com suas dificuldades e perplexidades. Por meio de cartas que circulavam entre as assembléias dominicais, os povoados recebiam informações sobre a doutrina cristã, configurando uma situação parecida com os cursos em apostilas que iriam existir muitos séculos mais tarde.

Bates (1995) também menciona as epístolas de São Paulo, mas aponta o início do sentido moderno da EAD no século XIX, com o estabelecimento da educação por correspondência, possível com o desenvolvimento de serviços postais rápidos e confiáveis. Nessa época, muitos indivíduos completaram os exames da Universidade de Londres sem jamais terem vivido na Inglaterra. O começo da EAD para esta instituição foi em 1858, quando uma lei determinou que, para obter um de seus diplomas, não mais seria necessário a um aluno estudar em um lugar específico. Os exames seriam realizados em diversas localidades distantes de Londres e as aulas poderiam ocorrer em qualquer escola ou por meio de estudos particulares, na residência do aluno, sozinho ou acompanhado de um tutor. As necessidades surgidas com a revolução industrial estimularam uma expansão da educação, mas mantiveram os mesmos modelos educacionais que existiam desde o século XV, tendo o texto impresso como o meio principal para a preservação e a disseminação de idéias.

No século XIV, após o salto tecnológico representado pela invenção da prensa de Gutemberg, houve uma modificação significativa nas formas de difusão da informação, que durante os 3000 anos anteriores ocorreu com o contato pessoal entre mestres e aprendizes. A 
produção de livros em ampla escala tornou desnecessária a leitura em grupo dos raros livros copiados manualmente, possibilitando que estudos fossem realizados em qualquer local, mesmo que distante do mestre. A liberdade de transporte da informação marca o caminho de dois processos: a evolução tecnológica e a apropriação das novas tecnologias pelos sistemas de educação a distância.

Após a prensa de Gutemberg, o próximo avanço marcante para o progresso da EAD, o correio, criou condições para o surgimento dos cursos por correspondência. A expansão das linhas ferroviárias em vários países do mundo possibilitou comunicações ágeis e seguras, garantindo a circulação de materiais educacionais, documentos e exames. Para a Universidade de Chicago, em 1882, nos Estados Unidos, tal oportunidade ocasionou o primeiro programa universitário realizado a distância naquele país (NISKIER, 1999). Moore e Kearsley (2007) destacam a importância do sistema de correspondência para o "estudo em casa" (home study) de mulheres, a quem em grande parte era negado o acesso às instituições formais, e na educação das forças armadas americanas, oferecendo aprendizagens para aqueles prestando serviço militar. $\mathrm{Na}$ Europa a educação a distância teve um papel importante em tempos de guerra, contribuindo para que indivíduos envolvidos em combates continuassem seus estudos. Durante as duas Grandes Guerras, a Universidade de Londres adaptou o seu external system para melhor atender a demanda educacional especial da época, alcançando inclusive os prisioneiros de guerra ${ }^{14}$ (KENYON JONES, 2008).

$\mathrm{Na}$ Inglaterra de 1900, muitos professores enfrentavam um problema que existe no Brasil de hoje: não conseguiam estudar para obter qualificações que aumentariam seus salários e melhorariam sua atuação profissional. Por isso, mais de 80 por cento das matrículas no University Correspondence College na época eram direcionadas para a carreira do ensino (KENYON JONES, 2008: 164). A situação das mulheres professoras era ainda mais complicada, pois freqüentemente recebiam somente a metade dos salários que seus colegas homens ganhavam e não podiam arcar com os custos para se titularem.

Complementando o sistema dos correios, a tecnologia do telefone seria usada para a resolução de questões, agilizando as trocas que antes aconteciam apenas pelo intermédio de cartas. Embora o aparelho telefônico gerasse oportunidades de interação em tempo real, o alto

\footnotetext{
${ }^{14}$ A educação em campos de prisioneiros ocorreu nas duas Guerras Mundiais, mas foi mais intensa na segunda, devido à Convenção de Genebra, assinada em 1929, que estabelecia regras para o tratamento de prisioneiros de guerra (KENYON JONES, 2008: 92).
} 
custo das ligações e as limitações implicadas em uma conferência somente via áudio, realizada com os equipamentos de telefonia usuais, não fizeram do telefone um recurso comum na EAD. As audioconferências depois seriam aperfeiçoadas e barateadas, representando uma forma importante de comunicação entre professores e alunos.

No começo do século XX, o surgimento do rádio deu origem à transmissão de falas educacionais, possibilitando que o primeiro programa escolar regular fosse levado ao ar pela BBC, em 1926 (BATES, 1995). A leitura de textos se beneficiou com as diferentes interpretações possíveis a partir de modulações da voz e ênfases em determinadas palavras, dando forma a um meio educacional efetivo, simples e de baixo custo. Posteriormente, o áudio seria utilizado também em fitas cassetes, com a vantagem adicional do controle para repetir trechos e interromper a escuta quando necessário, além da alternativa para gravar os programas transmitidos pelo rádio. Mesmo que anteriormente discos de gramofone tenham sido utilizados com finalidades educacionais, como será colocado no próximo capítulo, foi com a fita cassete que houve um barateamento do áudio gravado. Pesquisas demonstram que a inovação tecnológica mais importante nos primeiros 20 anos da Open University, no Reino Unido, em termos de alunos e cursos afetados e do impacto no aprendizado, foi a fita cassete (MoORE e KEARSLEY, 2007). Somente no final dos anos 90 isso mudaria, quando os aparelhos de CD e DVD tornaramse as tecnologias dominantes, pois apresentavam maior durabilidade e custos mais acessíveis.

O cinema serviu como meio educacional desde a sua criação, em 1895. Há vários registros de filmes mudos direcionados para o ensino médico, sendo o mais antigo uma cirurgia realizada pelo doutor Doyen, em 1898. Em 1910 o cinema educativo já era tema de um congresso na cidade de Bruxelas (Pfromm NetTo, 2001). No entanto, somente após o cinema tornar-se sonoro, em fins dos anos vinte, que os filmes tiveram uma aplicação mais vigorosa em escolas, até eventualmente serem substituídos em grande parte pela televisão, na segunda metade do século XX. A televisão educativa para adultos teve seus primórdios em 1934, quando a State University of Iowa realizou transmissões sobre higiene oral e astronomia (MOORE e KEARSLEY, 2007), e desenvolveu-se na Inglaterra a partir de 1963, com programas na BBC e nas redes britânicas comerciais (BATES, 1995).

Em 1969, o estabelecimento da universidade aberta britânica, a Open University (OU), representou um marco fundamental na história da educação a distância. Segundo Moore e 
Kearsley (2007), embora esta não fosse a primeira instituição inteiramente dedicada ao aprendizado a distância, pois a University of South Africa já havia sido criada com esta finalidade logo após o final da Segunda Guerra Mundial, em poucos anos a OU obteve um grau de excelência que se tornou um modelo para instituições similares ao redor do mundo. Dentro do conceito de aprendizagem aberta, a OU não exigia instrução prévia de seus alunos e um curso podia ser começado em qualquer época, buscando proporcionar o ensino para o maior número possível de indivíduos, com uma "política de admissão baseada em atendimento do tipo primeiro a chegar, primeiro a ser atendido" (MOORE e KEARSLEY, 2007).

Esta fórmula não surgiu sem críticas, com afirmações de que a proposta tinha interesses políticos, não havia pesquisa suficiente para embasar o projeto e seriam poucas as justificativas para os altos investimentos necessários (KEMBER, 2007). A oposição foi neutralizada de diversas formas, com a atuação de figuras como o primeiro ministro Harold Wilson e Lord Goodman, que negociou horários de transmissão com a rede de televisão BBC e arranjou patrocinadores. Desde o começo de suas atividades, a Open University dispôs de 35 horas semanais na BBC, mas rapidamente a competição com os canais comerciais forçou que a transmissão dessa programação educativa ocorresse em horários difíceis para os estudantes, muito cedo pela manhã ou muito tarde, durante a noite (BATES, 1995). Então, assim como a fita cassete facilitou as gravações de áudio, o videocassete viria possibilitar o registro e a circulação de programas de vídeo, abrindo um acesso assíncrono aos conteúdos transmitidos, com alternativas bastante econômicas para a distribuição pelo correio.

Posteriormente, o vídeo seria um meio para comunicações síncronas, com interações realizadas via satélite, que iriam abrir um novo leque de facilidades educacionais. Logo após o lançamento do satélite Early Bird, em meados da década de 60, universidades americanas já começaram a fazer experiências nesse sentido, como a University of Alaska, que oferecia cursos de educação continuada para professores. As videoconferências também resultaram em grandes avanços na educação corporativa, pois as empresas constataram que podiam oferecer treinamentos específicos sobre seus produtos, para todas as suas filiais, utilizando suas próprias redes privadas de televisão. Muitas empresas montaram verdadeiras universidades, as universidades corporativas, sendo que algumas construíram campi físicos, como a Motorola University, enquanto outras existem somente virtualmente, como a Dell University. 
Após a criação da Open University na Inglaterra, dezenas de instituições semelhantes surgiram em outras regiões, contribuindo para o crescimento da educação em muitas nações em desenvolvimento. Perraton (2000) cita projetos realizados em diversos países, como Paquistão, Índia, Indonésia, China, Coréia do Sul, Quênia, Malawi, Zâmbia, Zimbábue, Camarões, El Salvador, Costa Rica e México. Na Índia, por exemplo, o uso da educação por correspondência começou na Universidade de Delhi, em 1962, iniciando um processo que levou a EAD para outras universidades e culminou com o estabelecimento da Indira Gandhi National Open University, em 1985. O número de alunos matriculados nessa instituição em 1990 era de 50.000 (PERRATON, 2000) e em 2008 chegava quase a 2 milhões ${ }^{15}$.

Como Niskier (1999) observou, o progresso da EAD nos países em desenvolvimento sempre esteve sujeito às condições de infra-estrutura de cada local, pois muitas vezes não existiam serviços postais e telefônicos confiáveis. Por conta disso, em muitos países da África, a tecnologia mais popular é o rádio a pilha, que não depende nem de eletricidade. Surgia uma questão crucial: “como avançar em EAD sem ter sequer energia elétrica?” (NISKIER, 1999: 263). Além disso, o modelo da Open University britânica obteve sucesso com os alunos daquela instituição, mas pode não atender muitas das necessidades características de alunos nos países em desenvolvimento. Um estudo de Kember (2007) apresenta evidências de que nesses países os estudantes freqüientemente não são preparados para formas de aprendizagem que exigem o autogerenciamento e a habilidade de estudar, na maior parte do tempo, sem a presença do professor ou de colegas. Esta seria a explicação para o baixo índice de conclusão de curso nas universidades abertas de muitos países em desenvolvimento.

Por outro lado, a educação a distância tornou-se muito importante em países desenvolvidos, contribuindo para solucionar problemas gerados por regiões geladas e populações espalhadas ao longo de grandes extensões geográficas. Destacam-se os projetos Schoolnet no Canadá, utilizando Internet e satélites; NKS na Noruega, com experiências iniciadas em 1914; e os diversos esforços realizados na Austrália, onde áreas isoladas começaram a receber cursos por correspondência ainda durante a Primeira Guerra Mundial (NISKIER, 1999). Nesses países, o alto poder econômico sempre permitiu o uso das tecnologias mais recentes, usualmente conectadas via sistemas computadorizados.

\footnotetext{
${ }^{15}$ Segundo os dados no website da universidade (http://www.ignou.ac.in), verificados em julho de 2009.
} 
A utilização de redes de computadores na EAD começou com o "modo audiográfico", no qual imagens gráficas e áudio eram transmitidos por duas linhas telefônicas independentes, para assegurar uma boa qualidade na comunicação. As primeiras experiências nesse sentido foram realizadas por Michael Moore, em 1989, na Pennsylvania State University, para o ensino de cursos de graduação completos a alunos no México, na Finlândia e na Estônia, assim como em várias outras partes dos Estados Unidos. Com o surgimento da Internet, na década de 90, universidades começaram a oferecer cursos e programas de graduação online, a exemplo do New York Institute of Technology, da New School for Social Research e da International School of Information Management, todas nos Estados Unidos. Outras instituições foram criadas especificamente para atuar online, sendo denominadas universidades virtuais.

Embora a Internet represente a mais importante inovação na educação a distância nas últimas décadas, a promessa de sucesso das universidades virtuais não se concretizou, como deixa claro o fracasso da e-University do Reino Unido. A United Kingdom e-University (UKeU) surgiu no início de 2000, com grandes investimentos do governo britânico, mas foi fechada dois anos depois, devido ao baixo número de alunos matriculados. Se este modelo educacional é frágil em países com uma boa infraestrutura técnica, certamente não seria uma opção viável em áreas menos desenvolvidas (KEMBER, 2007). Por outro lado, a Internet abriu diversas novas alternativas para os formatos de EAD já existentes. Com a tecnologia VoIP (voice over Internet protocol), por exemplo, foi possibilitada a transmissão de áudio e vídeo a custos baixíssimos, tornando as teleconferências, antes limitadas a instituições capazes de arcar com altos gastos em equipamentos, acessíveis a qualquer indivíduo conectado à rede.

Além de comunicações com voz e imagem via Internet, na atualidade, muitos cursos de EAD também utilizam sistemas denominados ambientes virtuais de aprendizagem, em que são combinadas diversas ferramentas online, como fóruns e bate-papos. Um destes ambientes, o Moodle, foi utilizado na elaboração e na aplicação do curso de percussão que será descrito nos capítulos 6 e 7. Algumas de suas características serão detalhadas oportunamente, colocando em evidência o estado da arte da educação a distância e apontando para os seus caminhos futuros. 


\subsection{Universidade Aberta do Brasil (UAB)}

As origens da EAD no Brasil datam do início do século $\mathrm{XX}$, com cursos de ensino por correspondência. Vários exemplos podem ser destacados ainda na primeira metade desse século, como a "Universidade do Ar", um projeto organizado pelo Serviço Nacional de Aprendizagem Comercial (SENAC), entre 1947 e 1960, alcançando 80.000 alunos na área do comércio. Na década de 1970, o Brasil foi um dos líderes em educação a distância no mundo, ao lado do Reino Unido, Espanha, Índia e Canadá. Entretanto, com o controle legal exercido pelo governo brasileiro em anos subseqüentes, criando leis que enrijeciam as tentativas de experiências na área e tornavam o processo de mudança educacional extremamente burocrático, o avanço da EAD foi contido.

Se é possível a grosso modo distinguir as políticas européias no setor educacional, com seu alto grau de centralização, das políticas norte-americanas, altamente descentralizadas, normalmente delegando a responsabilidade sobre questões de validação acadêmica e qualidade para mecanismos de autoregulamentação e confirmação por associações regionais das instituições, então o Brasil certamente pertence à escola européia de administração educacional (LiTTO, 2008a: 1-2).

Em muitos países, a legislação regendo a educação a distância não é específica, pois a educação é considerada como um todo e a avaliação das instituições não discrimina os cursos a distância dos presenciais. Enquanto isso, uma série de leis brasileiras separa a EAD e o ensino convencional, exigindo a aprovação do Ministério da Educação para cursos a distância, mesmo que uma determinada instituição já tenha sido considerada apta a oferecer o mesmo curso presencialmente. Apesar do artigo 207 da Constituição Federal de 1988 garantir autonomia didática, científica, administrativa e financeira para todas as universidades do país, todas as instituições, públicas e privadas, que são autorizadas pelo Ministério da Educação a utilizar o termo "universidade" em seus nomes, devem submeter-se à aprovação ministerial para iniciar novos cursos ou programas (LITTO, 2008a).

Situando a visão da EAD em meio a um contexto histórico-cultural no Brasil, Litto (2008a) identifica relações de poder e controle que são vestígios do legado advindo da colonização portuguesa, com modelos surgidos nas monarquias européias absolutistas dos 
séculos XVII e XVIII. Nos primeiros 300 anos da colônia, a coroa portuguesa proibiu a publicação de livros, e somente após a vinda do rei de Portugal e sua corte ao Brasil, fugindo da perseguição de Napoleão no início do século XIX, escolas de medicina, direito e mineração foram criadas e as publicações foram permitidas. Formado este cenário inicial, torna-se evidente que o modelo educacional brasileiro atual ainda sente o reflexo de um passado centralizador e regulador. Por isso, embora existam evidências de que o povo brasileiro é extremamente ativo no uso de novas tecnologias (por exemplo, a alta média de horas mensais na Internet e a maioria absoluta de declarações de imposto de renda submetida online), há uma apatia quando se fala no uso destas tecnologias na educação (LiTTO, 2008b). Ainda assim, após projetos bem sucedidos como o Telecurso2000, em anos recentes pode-se constatar um aumento na credibilidade da educação a distância no país. A crescente aceitação desta modalidade na comunidade acadêmica, segundo Litto (2008a), em grande parte surgiu como conseqüência das conferências, seminários e publicações científicas da Associação Brasileira de Educação a Distância (ABED) ${ }^{16}$.

Dentro deste processo de abertura para a EAD, em 2001, a portaria 2253 do Ministério da Educação permitiu que qualquer curso já autorizado pudesse empregar métodos não-presenciais de ensino, desde que não se ultrapassasse o limite de $20 \%$ do tempo total do programa de estudos. As instituições que iniciaram trabalhos com educação a distância nessa época utilizaram sistemas híbridos, inserindo atividades a distância em seus cursos convencionais, não por opção pedagógica, mas por ser a única alternativa legalmente possível no campo da educação formal (LiTTO, 2002). Mais tarde, após várias tentativas mal sucedidas, com o decreto 5.800, sancionado pelo Presidente da República em 2006, foi instituída a Universidade Aberta do Brasil (UAB), objetivando utilizar a modalidade de educação a distância para expandir a oferta de cursos e programas de educação superior no país. A criação de uma instituição "aberta" uma demanda educacional que o sistema convencional de universidades não conseguiu suprir, assim como ocorre em muitos outros países em desenvolvimento (KEMBER, 2007). Em 2007, por

\footnotetext{
${ }^{16}$ A ABED (Associação Brasileira de Educação a Distância) é uma sociedade científica sem fins lucrativos, criada em 1995, que realiza um congresso internacional anual e reuniões e seminários regionais regulares. Sua página na Internet (http://www.abed.org.br) publica a "Revista Brasileira de Aprendizagem Aberta e a Distância", dedicada a estudiosos da EAD. A associação é filiada ao International Council for Open and Distance Education (ICDE), tem sede administrativa em São Paulo, e conta com pólos distribuídos em 27 cidades brasileiras.

${ }^{17}$ Embora o termo "aberto" seja utilizado para nomear a Universidade Aberta do Brasil, alguns elementos do projeto caracterizam instituições "fechadas": o vestibular para selecionar os alunos ingressantes e a existência de requisitos de educação anterior. A gratuidade dos cursos, por outro lado, pode ser considerado um elemento de "abertura".
} 
meio deste novo projeto, o Ministério da Educação disponibilizou 46 mil vagas de ensino superior.

O sistema Universidade Aberta do Brasil (UAB) não propõe a criação de uma nova instituição de ensino, mas sim, a articulação das já existentes, possibilitando levar ensino superior público de qualidade aos municípios brasileiros que não possuem cursos de formação superior ou cujos cursos ofertados não são suficientes para atender a todos os cidadãos. ${ }^{18}$

Na primeira etapa de funcionamento da UAB, foi lançado um edital para a implantação de uma rede de pólos de apoio presencial, assim como para o credenciamento das universidades federais interessadas em oferecer cursos. A Universidade Federal de São Carlos (UFSCar), com um projeto concebido por três de seus professores (JOLY, SANTIAGO e GOHN, 2007), encaminhou uma proposta que resultou no curso de Licenciatura em Educação Musical a distância, iniciando as atividades da primeira turma em 2007. Tendo como objetivo "um estreitamento das relações entre os profissionais que trabalham com educação musical e os recursos musicais, didáticos e tecnológicos atuais" (JOLY, SANTIAGO e GoHN, 2007: 37), o curso visa a capacitação de educadores para lidar não somente com o ensino da música, mas também com as possibilidades abertas pelas tecnologias, como preparar CDs com composições dos alunos, vídeos com atividades lúdicas realizadas nas aulas, materiais didáticos como partituras e arranjos, e criar websites na Internet.

Outros projetos já tinham utilizado a educação a distância na formação de professores de música no Brasil. Os trabalhos de Souza (2003), Cajazeira (2004), Krüger (2006) e Henderson Filho (2007) são exemplos disso e representam marcos importantes na história da educação musical brasileira. Serão, portanto, referências essenciais para todos os esforços futuros de uso da EAD na área, como o curso da UAB - UFSCar. No entanto, o alcance e a abrangência dos projetos desses pesquisadores foram limitados a um determinado período e a uma certa quantidade de participantes, causando transformações somente no universo em que atuaram. $\mathrm{O}$ surgimento de três cursos de licenciatura em educação musical (organizados pela UFSCar, pela UnB e pela UFRGS), em contrapartida, sinala mudanças em larga escala, iniciando processos de longo prazo que poderão ser estendidos a outras universidades.

\footnotetext{
${ }^{18}$ Fonte: <http://www.uab.mec.gov.br>. Acesso em 11/06/2008.
} 
Uma das disciplinas que fazem parte da proposta da UAB - UFSCar é "Percussão", servindo como objeto de estudo para a pesquisa de doutorado aqui apresentada. Para a sua realização, foram essenciais muitos dos meios de comunicação musical, que serão discutidos em profundidade no próximo capítulo. 


\section{Meios de comunicação musical}

Nesta pesquisa, as ferramentas que tornam possível a educação musical a distância serão denominadas "meios de comunicação musical". Sem elas, a tarefa de transmitir conteúdos de música seria muito mais complicada e as possibilidades para ensinar e aprender música sem ter contato pessoal direto e constante com professores ou mestres seriam menores, ou quase inexistentes. Conhecer o desenvolvimento de algumas dessas ferramentas cria um embasamento para compreender o atual estágio da educação musical a distância, identificando de que maneira o uso das tecnologias influenciou os processos educacionais da música.

Como foi visto anteriormente, a evolução das metodologias de EAD acompanhou o desenvolvimento tecnológico de cada período histórico. Neste capítulo, ficará claro que o mesmo aconteceu com as metodologias de educação musical: novas formas de ensinar e de aprender surgiram, na medida em que aumentaram a diversidade e a complexidade das maneiras pelas quais se transmite música e materiais educacionais sobre música. A vivência musical dos indivíduos também foi transformada, com a abertura de diferentes oportunidades e novas formas de se relacionar com a música.

Pode-se observar que nenhuma invenção tecnológica é completamente neutra, pois a existência de um novo artefato, mecanismo ou sistema sempre provoca mudanças de pensamento e novas visões de mundo. A estreita relação entre música e tecnologia que se estabeleceu ao longo da história demonstra que, enquanto as inovações possibilitavam o desenrolar de outras formas de manifestação artística, assim como de outras práticas e teorias educacionais, a tecnologia também era adaptada aos novos padrões de cada época.

Para aprofundar as afirmações colocadas acima, quatro tipos de meios de comunicação musical foram selecionados: a notação musical, a gravação sonora, as tecnologias digitais e os softwares educacionais (incluindo aqueles disponíveis em websites). A partir desses tópicos são identificadas transformações na música e nas formas de aprender música, modificando seus conteúdos e as formas pelas quais se tem acesso a ela, e gerando pesquisas que foram necessárias para uma formalização do som a ser integrado nas novas tecnologias. Exemplos serão detalhados ao longo desse capítulo, evidenciando algumas mudanças nas maneiras de transmitir música e conteúdos educacionais sobre música. 
A falta de neutralidade de toda e qualquer inovação tecnológica pode ser notada em diversas áreas. Por exemplo, o surgimento dos óculos, em meados do século XII, não somente ajudou aqueles com deficiências visuais a enxergar melhor, mas também refutou toda uma concepção de que os desgastes naturais do corpo humano ou os problemas de nascença deveriam ser aceitos como irreversíveis (PosTMAN, 1985). A partir daquele instante, muitos sofrimentos e desconfortos já não seriam mais considerados normais, e os progressos científicos passaram a representar uma luta contra processos usuais da natureza.

Outro caso que pode ser citado ocorreu quando a invenção do telégrafo, no final do século XIX, acabou com a idéia de que uma notícia só poderia viajar fisicamente na mesma velocidade de seu portador. Antes da existência daquele aparelho, o alto esforço e a demora necessária para transportar uma informação até locais distantes limitava a comunicação ao extremamente essencial, e frequientemente as notícias transportadas poderiam não mais ser relevantes ao chegar ao seu destino. Com a comunicação instantânea proporcionada pelo telégrafo, muitas informações que anteriormente não seriam consideradas importantes passaram a ser veiculadas, pela simples razão de que havia uma facilidade tecnológica para tal feito. Como diz Postman (1985: 65), “o telégrafo transformou informação em mercadoria, uma 'coisa' que podia ser vendida e comprada independente de seu uso ou significado".

Dentro deste mesmo olhar, o surgimento de novas tecnologias deu uma materialidade à música e aos conhecimentos utilizados na educação musical. Os meios físicos de registro de conteúdos musicais, na forma de notação musical, gravações sonoras e tecnologias digitais, e as possibilidades de transmissão desses registros via meios de comunicação em massa, como o rádio e a televisão, ou via computador, em CD-ROM ou na Internet, também transformaram a educação musical em "coisas". Os processos de educação musical a distância são parcialmente baseados no transporte dessas coisas, levando ao aprendiz os materiais que tornam possível a sua aprendizagem.

As relações entre educação musical e o surgimento do rádio, da fita cassete, da televisão, do videocassete, do CD e do DVD, já foram analisadas em trabalhos realizados no passado (GoHN, 2003). O aprendizado que acontece no cotidiano, em grande parte decorrente dessas mídias, tem sido objeto de estudo de grupos de pesquisa, resultando em importantes publicações acadêmicas (por exemplo: SouZA, 2008). As possibilidades desse aprendizado, agora ampliadas 
pelo contexto de música e tecnologia exposto na introdução da tese, criam situações bastante favoráveis para a consolidação de processos educacionais de música a distância. A seguir, separadamente, serão discutidos os quatro tipos de meios de comunicação musical selecionados.

\subsection{Notação musical}

O surgimento da notação musical causou a primeira grande revolução nos processos de transmissão do conhecimento musical. O significado deste acontecimento para a música ocidental, tanto em aspectos teóricos quanto práticos, é considerado por diversos autores como um evento de suma importância, comparável ao surgimento da escrita para a linguagem (ThÉBERGE, 1997 e WeBER, 1995) ${ }^{19}$. Com a notação, pela primeira vez uma informação musical poderia ser transportada em um suporte físico, não baseado na tradição oral e que não dependia da memória humana.

Anteriormente ao aperfeiçoamento dos sistemas de notação, a transmissão de conhecimentos sobre a música ocorria primordialmente por meio da tradição oral. Não havia uma forma de concretizar idéias musicais para serem utilizadas no ensino ou na aprendizagem da música, e assim o alcance de novas composições, estilos e propostas musicais ficava restrito fisicamente ao redor de artistas e professores. Os tratados de educação musical importantes, como De Institutione Musica, de Boécio $^{20}$, escrito durante a Idade Média, não dispunham de ferramentas para aprofundar suas discussões. Os sistemas de escrita musical criados não continham detalhes mínimos para o registro apurado de uma obra (THÉBERGE, 1997), como os neumas surgidos no século IX, espécies de acentos colocados juntos das palavras que indicavam de forma imprecisa os movimentos melódicos a cantar; ou a tablatura surgida por volta do século $\mathrm{XV}$, que servia especificamente para um único instrumento (para teclados ou para a lira, por

\footnotetext{
${ }^{19}$ Para Weber, “uma notação desta espécie é, para a existência de uma música tal como a que possuímos, de importância muito mais fundamental do que, digamos, a espécie de escrita fonética para a existência das formas artísticas lingüísticas - com exceção talvez da poesia hieroglífica e chinesa, onde a impressão ótica dos caracteres, devido a sua estrutura artística, pertence como elemento integrante ao gozo completo do produto poético" (WEBER, 1995: 119).

${ }^{20}$ Em De Institutione Musica (Os Princípios da Música), Boécio resumiu os pensamentos gregos sobre música, descrevendo as idéias de Pitágoras sobre matemática e música e os conceitos de Platão sobre música e sociedade. Foi o maior tratado musical de sua época, permanecendo como uma das principais fontes de informação sobre as relações entre matemática e música por mais de um milênio (MARK, 2002).
} 
exemplo) e não determinava as alturas exatas que deveriam soar. Essas formas iniciais de notação não tiveram, portanto, uma importância capital na história da educação musical.

Com as inovações de Guido D'Arezzo, por volta do ano 1000, houve o desenvolvimento da pauta de quatro linhas e posteriormente da pauta de cinco linhas, utilizada até hoje, com a pretensão de "remediar as arbitrariedades possíveis" (WEBER, 1995: 124). As formas de registro aperfeiçoadas aumentaram a quantidade de informações contidas na notação musical e deram um maior controle aos compositores sobre suas obras. Assim, um aprendiz poderia receber a partitura de um artista que nunca havia encontrado pessoalmente e ter acesso a suas composições. Até aquele ponto, a única maneira de aprender com um mestre era estar presente fisicamente junto a ele. A partir do instante em que a informação podia viajar separadamente de seu criador, teve início uma nova era para a humanidade, beneficiando também os processos educacionais da música.

Mesmo após o seu aperfeiçoamento, a notação musical sempre apresentou muitas imprecisões, deixando uma larga margem de interpretação para os músicos, pois registra com exatidão somente alguns parâmetros. Caso um intérprete tenha acesso a uma determinada peça somente por meio de partitura, sem jamais ouvir outro músico executando aquela música, ele terá que completar as informações faltantes a partir de suas próprias experiências e conhecimentos, imaginando as intenções originais do compositor ou imprimindo seu estilo pessoal na execução. Aaron Copland exprimiu a frustração que esse fato causa a um compositor:

Eu gostaria que nossa notação e nossas indicações de tempos e dinâmicas fossem exatas, mas a honestidade me força a admitir que a página escrita é apenas uma aproximação; é apenas uma indicação de quão perto o compositor conseguiu chegar ao transcrever seus pensamentos para o papel. Além desse ponto o intérprete está sozinho (COPLAND, 1952: 49-50).

De qualquer maneira, a notação ampliou as formas de acesso à música oriunda de localidades distantes, dando uma materialidade ao som e quebrando as limitações temporais e geográficas que existiam para a obra de um artista. Com um registro mais específico de ritmos e linhas melódico-harmônicas, tornou-se possível entrar em contato com compositores de outros países e mesmo de outras épocas, fortalecendo as misturas e influências musicais que iriam aumentar com o passar dos séculos. Mais tarde, as gravações sonoras iriam ampliar esse 
processo, para o qual Michel Chion (1994: 71) sugere o nome de "mundialização da música". Um exemplo das mesclas ocorridas no Brasil é a bossa nova, um estilo resultante da fusão da música brasileira com elementos advindos do jazz norte-americano. Pelo outro lado, Berendt (2007: 229) observou como violonistas brasileiros, especialmente Baden Powell, "influenciaram de maneira fascinante toda uma geração de guitarristas dos Estados Unidos”.

Portanto, assim como a escrita da linguagem, a notação musical não é uma tecnologia neutra que depende do uso que é feito dela. Mais importante do que as pessoas vão escrever, é o fato de que as pessoas irão escrever, pois a possibilidade de registrar idéias em um suporte fixo traz ao mundo uma nova concepção para a palavra "informação". O valor de informações colocadas no papel e disseminadas através de livros remodelou as relações de poder, dando privilégios àqueles que tinham acesso ao material codificado e condições de decifrá-lo. Logo, não é apenas uma facilitação de acesso, e sim uma reconfiguração do alcance e da importância do que está escrito.

Da mesma forma, mais importante do que aquilo que as pessoas vão compor é o fato de que composições podem ser registradas em partituras. Como diz Postman (1993: 7), "os usos de qualquer tecnologia são amplamente determinados pela estrutura da própria tecnologia - ou seja, as suas funções seguem a sua forma”. Conclui-se que, após o advento da notação musical, os usos que foram feitos dela, seja para a criação de novas músicas ou para o aprendizado de músicas já existentes, foram determinados pelas estruturas convencionadas para representar os sons em sinais gráficos.

Para Théberge, aprender a tocar um instrumento musical com a mediação de partituras muda a natureza do próprio processo de aprendizagem, pois no "treinamento técnico de instrumentistas de tradições musicais baseadas na notação, a aquisição de habilidades é padronizada na forma do étude" (THÉBERGE, 1997: 183). Assim, o desenvolvimento técnico passou a ocorrer de forma similar para todos aqueles que estudavam com um mesmo método de partituras. No início do século XVI, surgiram os primeiros livros instrucionais para instrumentistas e cantores, assim como coleções de partituras organizadas primordialmente para o entretenimento de músicos amadores.

A realidade de que se poderia escrever música foi um fator determinante na história da música ocidental. Não apenas existia a possibilidade de se aprender novas idéias e concepções, 
como também o próprio conteúdo musical a ser transmitido passou por transformações. Exemplos podem ser encontrados no desenvolvimento da polifonia vocal, quando uma racionalidade decorrente do planejamento que a notação permitia resultou em uma música mais complexa (WEBER, 1995). Anteriormente à escrita, as composições eram mais simples para serem fáceis de memorizar, e também não existiam condições para o surgimento das linhas de harmonia polivocal.

Com o desenvolvimento de complexidades rítmicas que deveriam ser retratadas pela escrita musical, tiveram origem novas fórmulas de compasso, ligaduras, pontos e várias outras formas de grafia criadas para a representação de ritmos. Os sistemas de notação precisavam ser mais completos para atender às novas necessidades da música, e conseqüentemente a música passava por transformações ainda maiores na medida em que a notação tornava-se mais complexa. Tal processo é confirmado por Biocca (1988: 64), quando este diz que "o artista expressa mudanças culturais e perceptuais enquanto, ao mesmo tempo, atua como catalisador destas mudanças".

A função da notação antes desta época tinha sido primariamente descrever, ou seja, uma tentativa de registrar exatamente a essência de uma tradição oral. Agora se tornava prescrever - uma lista de instruções mais ou menos definidas escritas por um indivíduo para ser executada por outro (THÉBERGE, 1997: 178).

Com esta nova situação, um aprendiz da música, que anteriormente iria concentrar seus estudos na produção de sons, deveria também aprender a interpretar os sinais gráficos que representavam aqueles sons. Toda uma nova gama de práticas surgiu, envolvendo não somente os ouvidos e os instrumentos musicais, mas também os olhos. Há músicos que preferem aprender uma nova peça escutando-a, enquanto outros têm mais facilidade lendo a partitura. De qualquer maneira, mais uma habilidade passou a ser freqüentemente exigida e foi integrada na rotina de estudos dos aprendizes.

Outra conseqüência do desenvolvimento da notação musical, que também ocorreu quando surgiram a gravação sonora e as tecnologias digitais, foi uma formalização da música. Para a criação de aparatos e sistemas que representem ou permitam uma manipulação do material sonoro, é preciso haver uma organização das informações, para que as mesmas sejam inseridas no novo contexto. Por exemplo, na formalização escrita, foram criadas appoggiaturas e outros 
ornamentos para registrar no papel determinados sons. Estes sons deveriam ter uma definição formal, diferenciado-os uns dos outros e relacionando-os com os símbolos inventados para sua representação. Cada elemento da música foi, gradualmente, sendo identificado, analisado e compreendido, para que fosse tratado de forma coerente.

Portanto, para escrever os fenômenos musicais em uma partitura, é preciso ter uma boa compreensão de suas características e nuanças. Também para o registro sonoro é preciso um domínio apurado da música e suas qualidades acústicas. No início do século XX, um som demasiadamente grave faria a agulha de gravação pular, e por isso era importante saber quais sonoridades poderiam ser utilizadas, assim como o posicionamento dos músicos na sala de gravação, em relação ao ponto de captação sonora, dependia das características de cada instrumento emissor. Com as tecnologias digitais, principalmente nas pesquisas de síntese sonora, houve grandes avanços na compreensão dos elementos físicos que compõem o som, identificando-se os harmônicos que caracterizam cada sonoridade.

\subsection{Registro sonoro}

A patente do fonógrafo foi concedida ao americano Thomas Alva Edison no dia 19 de Fevereiro de 1878, e a partir desta data intensificou-se o processo de desenvolvimento dos meios de gravação sonora. Com este invento, o som poderia ser registrado em um meio físico e depois reproduzido, ao contrário do telefone, inventado pouco antes por Alexander Graham Bell, que podia apenas transmitir o som de maneira efêmera, perdendo qualquer informação que passasse por seus mecanismos. "O som agora era algo que alguém poderia segurar, analisar, medir e disseminar em forma exata" (BIOCCA, 1988: 64).

Em Junho de 1878, Edison divulgou uma lista de dez usos que seu fonógrafo poderia ter no futuro, segundo suas suposições. A maioria estava relacionada com a reprodução da voz humana, e havia apenas um item indicando que o aparelho seria "sem dúvida livremente devotado à música" (DEARLing e DeARLING, 1984: 21). Edison também mencionou as finalidades educacionais que a máquina poderia apresentar, citando sua utilização na aprendizagem da pronúncia correta de palavras e o registro de explicações de professores para consultas posteriores. Em 1911, a Victor Talking Machine Company estabeleceu um 
departamento educacional, com a missão de estimular a presença dos aparelhos de reprodução sonora nas escolas. Posteriormente, a utilização de gravações na educação ocorreu em muitas áreas, principalmente no ensino de línguas e de música ${ }^{21}$. Diversas gravações foram produzidas com o objetivo de organizar uma história da música, e outras tantas tinham o intuito de servir como acompanhamento para aprendizes, pois vinham com uma parte do instrumental faltando, que deveria ser completada pelo estudante ${ }^{22}$.

Nas primeiras décadas do século XX, muitos professores temiam que o som gravado fosse desencorajar indivíduos na leitura de livros e havia uma preocupação com as consequiências que a disseminação do fonógrafo poderia trazer à música. John Philip Sousa, por exemplo, afirmava que a "música enlatada" iria encolher o "pulmão nacional", por inibir a prática de exercício do canto, além de diminuir a quantidade de empregos para músicos (SousA, 1906). Se todos poderiam ouvir performances musicais gravadas, com interpretações muito superiores às que poderiam ser executadas pelos músicos amadores em uma casa, porque haveria a preocupação de aprender a tocar um instrumento? Muitos consideravam que essa seria uma forma de se livrar de amadores incompetentes, tirando um fardo tanto dos aprendizes como de seus ouvintes (KATZ, 2004).

Também havia restrições quanto à limitação de tempo de reprodução dos discos, que obrigava abreviações nas obras registradas, e à reformulação de arranjos baseada apenas nos instrumentos que podiam ser captados adequadamente pelos meios de gravação disponíveis. Mesmo com tais restrições por parte de alguns, o fonógrafo - e posteriormente o gramofone tornou-se um instrumento pedagógico, concomitantemente à valorização da apreciação musical como uma competência que deveria ser desenvolvida, merecendo atenção especial e treinamento adequado (SYMES, 2004).

\footnotetext{
${ }^{21}$ Por exemplo, foram produzidos os discos "Diga corretamente: como pronunciar nomes, títulos de músicas, termos, compositores e artistas" (1960); "Como tocar o órgão Hammond”, "Melhore sua etiqueta", "Pesque melhor", "Treine seu cachorro" e "Lembre-se de nomes e rostos" (1961); "Como vender", "Como pilotar um aeroplano" e "Como planejar um jantar perfeito" (1962); "Como ser um disk jockey" e "Guia para a pronúncia correta (inglês)" (1964); entre vários outros (DEARLING e DEARLING, 1984).

${ }^{22}$ Podemos citar, como exemplo do primeiro caso, Columbia History of Music (editado pelo Dr. Percy A Scholes, 1930-9); Two Thousand Years of Music (Parlophone, 1931-8); L'Anthologie Sonore (editado por Curt Sachs, 19349); e History of Music in Sound (editado por Gerald Abraham, 1953-9). No segundo caso, o primeiro disco com o objetivo de dar um acompanhamento musical para aprendizes de instrumentos musicais foi produzido na Áustria, em 1935, pela gravadora Tilophane. Depois, surgiram Add-A-Part (1942); Spiel Mit (1948); e Music Minus One (1949) (DEARLING e DEARLING, 1984).
} 
Segundo Katz (2004: 61), o objetivo da apreciação musical era promover uma compreensão da música nos alunos acima de sua própria capacidade de performance, e antes do acesso a gravações sonoras, a única forma de conseguir isso era trazer instrumentistas à sala de aula ou levar os estudantes à sala de concerto. Com o fonógrafo, qualquer lugar poderia ser transformado em um "museu da história da música", ouvindo-se tipos de música e níveis de performance que não eram limitados pelos talentos de professores, alunos ou músicos locais. A repetição contínua da audição de gravações também foi um fator importante, facilitando a absorção dos clássicos e incluindo peças raramente presentes em concertos públicos. Nos Estados Unidos, há referências de aparelhos sendo utilizados em cursos de apreciação musical desde 1913, na Mount Holyoke College e na Universidade de Wisconsin, e depois em várias outras instituições, justificando a afirmação de Katz (2004: 67) que "foi o fonógrafo que fez do estudo da música uma realidade em nível nacional” naquele país.

Na primeira metade do século XX, indo contra a postura do americano John Philip Sousa e contra as tradições de seu próprio país, destaca-se a recomendação do educador musical japonês Shinichi Suzuki, para que as crianças ouvissem gravações o mais cedo possível. No método Suzuki, ouvir discos é uma forma de ter referências de afinação e qualidade musical, proporcionando um mecanismo para a repetição constante de uma canção ou trecho musical. Suzuki chegou a fazer acordos com companhias gravadoras, que na época estavam em pleno desenvolvimento, para obter gravações tecnicamente superiores às outras disponíveis no mercado (FONTERRADA, 2005).

O surgimento da gravação sonora marcou o início de uma ampliação de repertório para os ouvintes, alcançando todas as obras que fossem registradas. Potencializado mais tarde pelos meios de comunicação de massa, o som gravado divulgou compositores e intérpretes, suas obras e performances; materiais que antes seriam desconhecidos de um grande público. Enquanto muitos autores consideram esta a verdadeira democratização da música, outros vêem tal facilidade de acesso como uma banalização (para exemplos de ambos, vide GoHN, 2003). O rádio, por exemplo, criou novas formas de se relacionar com a música, ao disponibiliza-la como pano de fundo para atividades domésticas e criar o que Chion (1994: 101) eventualmente iria chamar de "máscara acústica nos apartamentos modernos". Segundo esse conceito, com a crescente quantidade de informação em circulação no mundo, há uma diminuição da atenção dos 
ouvintes e uma conseqüente desvalorização da arte musical. Afinal, viver em meio a um turbilhão de músicas "nem sempre é a garantia de que o ser humano está, como nossos ancestrais, sendo ator de uma musicalidade" (SALLES, 2002: 99).

De qualquer maneira, após a invenção do fonógrafo a experiência musical jamais seria a mesma. A ampla circulação de informação alterou as formas pelas quais os ouvintes aprendem música e sobre música e causou mudanças no próprio conteúdo musical. Phillip (1992) observou diversas destas mudanças, ocorridas na transição entre dois mundos: o antigo mundo, em que os músicos eram ouvidos apenas durante performances em tempo real; e o mundo moderno, em que as performances podem ser ouvidas tendo-se como meio uma gravação. Analisando as gravações realizadas no início do século XX, Phillip notou como estas faziam parte do mundo moderno, pois estão disponíveis e podem ser ouvidas repetidamente, mas preservam performances do mundo antigo, remanescentes de apresentações que eram dirigidas unicamente para platéias. Comparando estas gravações com outras, realizadas no final do mesmo século, o autor identificou uma série de mudanças que evidenciam como as práticas musicais estavam direcionadas e priorizavam a gravação.

Se gravações do período pré-guerra são notavelmente como performances ao vivo, muitas performances da segunda metade do século XX são notavelmente como gravações. Controle e clareza de detalhes tornaram-se a prioridade na performance moderna, nas salas de concerto assim como no estúdio (PHILLIP, 1992: 231).

Em sua análise, Phillip faz colocações sobre a música orquestral de concerto, muitas das quais também se aplicam a outros gêneros. Nos registros do início do século, por exemplo, as mudanças de tempo eram drasticamente adotadas para sinalizar alterações na expressão ou nas tensões da música, e os tempos eram acelerados ao máximo. A flexibilidade nas interpretações das figuras rítmicas era muito maior, com deslocamentos nas melodias e acompanhamentos; e havia uma tendência a encurtar notas curtas e alongar as notas pontuadas. Os tempos mais lentos que usualmente são ouvidos hoje são decorrentes da ênfase na clareza rítmica, pois "todo estudante de música moderno está acostumado a ouvir que não deve acelerar as passagens mais fortes; 'correr' é considerado uma falta de controle" (PHILLIP, 1992: 234). Atualmente, embora alguma flexibilidade na interpretação rítmica ainda seja permitida, as variações gravadas no 
início do século soam desleixadas e imprudentes. Com exceção de alguns casos, como o jazz, na maior parte dos gêneros musicais há uma expectativa de regularidade rítmica e de sincronicidade entre melodia e harmonia.

Como consequiência da busca de maior clareza e precisão, a prática de ensaios contínuos tornou-se uma nova realidade. Segundo Phillip, nos padrões atuais, muitas das performances registradas no início do século XX nitidamente apresentam falta de ensaios. Hoje, um instrumentista deve estudar e ensaiar regularmente, sempre procurando correção em seus movimentos e interpretações rítmicas. Para o estudante moderno, a exigência de perfeição técnica estabelece patamares mínimos, já que as platéias tiveram acesso às gravações de muitos outros instrumentistas e há uma expectativa de ouvir uma qualidade igual ou superior àquelas referências anteriores.

Tais referências das platéias, proporcionadas pela gravação e suas diferentes formas de disseminação, são condicionadas pelas realidades técnicas existentes em cada época. Nas primeiras décadas do século passado, mesmo com uma qualidade de registro sonoro que atualmente é considerada de baixa fidelidade em relação ao material musical original, ouvintes poderiam confundir a gravação com a performance real. Entre 1915 e 1920, a companhia fundada por Thomas Edison patrocinou mais de quatro mil tone tests, demonstrações em que músicos interagiam com fonógrafos e buscavam misturar as partes que cada um estava executando. $\mathrm{O}$ intuito era deliberadamente confundir o público presente.

Ouvintes modernos, conhecedores do som gravado digitalmente e reproduzido em estéreo, podem achar difícil acreditar que as platéias não conseguiam distinguir entre o artista e a gravação (THOMPSON, 1995: 159).

Ao receber o som de outras maneiras que não são via performance em tempo real, o ouvinte tem a oportunidade de reconhecer timbres de instrumentos, comparando a gravação com o original e buscando identificar as diferenças entre ambos. Atualmente, a sonoridade do fonógrafo dificilmente poderia se fazer passar por um instrumento musical real, pois a alta qualidade dos equipamentos modernos deixa claro que os recursos tecnológicos antigos estão ultrapassados e muito distantes do som original. Para chegar a este estágio, os ouvintes passaram por etapas que tiveram início no deslumbramento até chegar à análise e julgamento das diferentes 
tecnologias disponíveis em cada período.

Quando o som começou a ser disseminado pelo rádio (e não necessariamente o som gravado, pois transmissões radiofônicas também ocorrem em tempo real), as frequiências altas e baixas eram "achatadas" e havia uma valorização das freqüências médias. O piano soava sem brilho e o contrabaixo causava distorção, enquanto o saxofone e a clarineta tinham destaque, ganhando popularidade naquela época (BIOCCA, 1988). Na medida em que a fidelidade das transmissões aumentou, os instrumentos eram ouvidos com características mais próximas de sua sonoridade verdadeira, proporcionando ao ouvinte referências timbrísticas mais realistas.

No final do século XX, a digitalização dos processos de gravação e reprodução eliminou ruídos estranhos ao som originalmente captado e abriu um novo universo de possibilidades para a manipulação do elemento sonoro. As mudanças nas formas de vivenciar a música tornaram-se ainda mais intensas, afetando tanto ouvintes como aqueles envolvidos nos processos de produção musical.

\subsection{Tecnologias digitais}

Até recentemente, mercados econômicos e pesquisa científica eram os únicos tipos de transações humanas mediadas por sistemas estáveis de medidas. As tecnologias digitais não apenas mudaram a forma como ciência e finanças são praticadas, mas estão expandindo o poder das medidas e da matemática para abranger a maioria das formas de comunicação humana (BINKLEY, 1995: 428).

A presença constante de sistemas digitalizados nas mais variadas áreas da vida humana é evidente para qualquer observador. Seja na medicina, no entretenimento, na educação ou em utensílios domésticos, é comum encontrar aparelhos que transformam informações em números, abrindo um vasto leque de opções para o tratamento de dados. As conseqüências deste fato para a experiência musical são de grande importância.

Como Binkley (1995) coloca, durante séculos os canais de comunicação foram baseados nos chamados meios analógicos. A notação e as gravações em fonógrafos são exemplos de meios analógicos, pois recebiam e preservavam fisicamente traços de eventos, imprimidos por ferramentas. O material do meio, seja o papel da partitura ou um disco de cera de um fonógrafo, eram inseparáveis da mensagem que carregavam. Por outro lado, com a digitalização, houve uma 
mudança de "sistemas relativamente passivos e escravizados em tecnologias baseadas em suportes físicos para sistemas interativos independentes de qualquer tecnologia particular para sua realização" (BINKLEY, 1995: 428).

Assim, depois que uma transcrição do meio analógico é feita para o meio digital, qualquer informação é facilmente transferida de um sistema a outro, através de cópias perfeitas, em que todas são originais. Por exemplo, as músicas de um CD podem ser copiadas para o disco rígido de um computador, enviadas por e-mail, acessadas de uma segunda máquina e colocadas em um outro CD. Com este procedimento, dois CDs com dados idênticos podem ser produzidos em poucos minutos, em duas regiões distantes do planeta. Com o suporte analógico, a gravação teria que viajar fisicamente até o local de destino.

Esta acentuada rapidez da comunicação moderna intensificou processos que já podiam ser identificados com o surgimento do rádio, aumentando a quantidade e a variedade de música em circulação pelo mundo. É evidente a facilitação do acesso a novos tipos de música: para entrar em contato com diferentes estilos, composições e artistas, é preciso apenas saber requisitar a informação, que fica disponibilizada o tempo todo, em qualquer local conectado à Internet. Portanto, é provável que futuramente ocorra uma ampliação da diversidade musical do planeta, expandindo os círculos que foram determinados pelos meios de comunicação de massa nas últimas décadas. Embora ainda exista uma divulgação de músicas que prioriza interesses econômicos, não raramente por parte de grandes empresas ligadas às mídias eletrônicas, as tecnologias digitais oferecem meios para acessar novas experimentações musicais, abrindo campo para aqueles dispostos a conhecer o novo.

As gravações musicais produzidas na atualidade, antes de chegar ao ouvinte, passam por diversos estágios em que ocorrem tratamentos digitais do som. Na extremidade final do processo, a recepção, a informação digital pode estar em um CD ou outro aparelho de reprodução sonora (como os players que se tornaram tão comuns para executar arquivos MP3); pode estar na Internet, em websites que vendem ou disponibilizam músicas, em sistemas de compartilhamento de dados ou em rádios transmitindo programação ao vivo ou pré-gravada ${ }^{23}$; pode estar no sistema

\footnotetext{
${ }^{23}$ No Brasil, em 1999, já havia 183 emissoras de rádio transmitindo sua programação ao vivo pela Internet (MOREIRA, 2002).
} 
de transmissão digital de uma estação de rádio ${ }^{24}$; entre outras possibilidades. Na extremidade inicial, a produção, as modificações ocasionadas pela manipulação digital da música implicaram em novos resultados musicais.

Primeiramente, para uma análise geral da música produzida a partir do século XX, é preciso compreender as fontes de emissão sonora utilizadas e observar que estas deram origem a novas sonoridades e a novos estilos musicais. Extenso material de pesquisa já foi publicado sobre o assunto, investigando o desenvolvimento de gêneros populares como o rock (JONES, 1992) ou o hip-hop (COLEMAN, 2003). No caso do rock, o surgimento da guitarra elétrica (uma tecnologia não digital) e mais tarde dos sintetizadores controlados por teclados eletrônicos foi decisivo para os resultados sonoros obtidos em cada variação do gênero. Na história do hip-hop, a manipulação analógica de gravações começou na Jamaica, e depois a digitalização do som iria aumentar a complexidade dos processos comandados pela figura que ganhou destaque: o disc jockey, ou simplesmente DJ.

Tanto no âmbito da música popular, encabeçada pelo rock a partir da década de 1950, quanto nos círculos da música de compositores experimentalistas, como a música concreta de Pierre Schaeffer ou a música eletrônica de Karlheinz Stockhausen, as sonoridades estão diretamente associadas à composição. Não haveria rock sem a guitarra elétrica e não haveria a música eletrônica sem a síntese sonora, e tal associação fica evidente quando um som do cotidiano é registrado e manipulado para se tornar parte da composição, como na música concreta. Neste cenário, o elemento digital iria tornar-se essencial, principalmente na década de 1980, quando os sintetizadores ficaram acessíveis a músicos fora do circuito dos grandes centros de pesquisas acadêmicas, onde investigações com estas máquinas aconteciam desde o início da década de 50. As chamadas workstations, ou "estações de trabalho", abriram possibilidades de criar sons e comandá-los através de teclados ou de outros controladores eletrônicos.

Se nos anos 50 a digitalização da música deu origem a novos estilos musicais, outras transformações estariam por acontecer para a experiência musical nos anos 2000, depois da popularização dos computadores pessoais, com as tecnologias de compactação de arquivos e a ampliação da largura de banda nas conexões com a Internet. A circulação de músicas digitalizadas cresceu através de várias formas, principalmente com sistemas peer-to-peer ( $\mathrm{P} 2 \mathrm{P})$,

\footnotetext{
${ }^{24}$ As pesquisas com formas de transmissão digital de áudio começaram em 1981, no Institut für Rundfunktechnik, em Berlim, Alemanha. O primeiro projeto de implementação ocorreu no mesmo país, em 1987. Atualmente já existem rádios transmitindo com sistemas digitais no Brasil e em muitos outros países (MOREIRA, 2002).
} 
em que usuários de redes de computadores trocam arquivos entre si. Surge o conceito de "música como água" (KUSEK e LEONHARD, 2005), conforme foi explanado na introdução da tese, prevendo um futuro em que ter acesso a qualquer música será tão simples quanto abrir uma torneira.

Equipamentos eletrônicos com custos progressivamente mais baixos levaram para o computador tarefas que antes eram realizadas com outras ferramentas. Por exemplo, softwares de notação substituíram a escrita direta no papel e softwares de gravação os registros em fitas magnéticas. Na contemporaneidade, pode-se constatar o uso destes programas digitais tanto por músicos profissionais quanto por diletantes sem formação musical específica, e assim como na aprendizagem musical através de études, o uso de um mesmo sistema computacional por diversos indivíduos tende a padronizar suas práticas e resultados.

O que temos hoje é uma proliferação de softwares de música que atuam como "teorias", bem diferentemente na influência cognitiva das teorias musicais tradicionais. Se o usuário não concorda tacitamente em ater-se ao uso formal e, em menor medida, ao foco artístico do sistema, então os resultados antecipados tornam-se menos previsíveis (RIDELL, 2001: 338).

Estas "teorias", como diz Ridell, não impõem um estilo ou dizem como escrever boa música, mas criam um enquadramento conceitual. Nesse sentido, a evolução da tecnologia gradualmente estabelece padrões nas formas de produzir e aprender música. Para se manter em sintonia com o próprio tempo, é preciso também aprender a lidar com as mediações tecnológicas que vão surgindo, somando-as ao corpo de conhecimentos existente anteriormente. Com o desenvolvimento da notação, havia uma expectativa de que músicos aprendessem a ler partituras; com a história da gravação e dos meios de comunicação, surgiu um novo universo de procedimentos (como tocar seu instrumento para um melhor registro sonoro, como manusear um aparelho para gravar e reproduzir o som); e com a digitalização do som, se espera que o músico aprenda a manipular arquivos sonoros com o auxílio de computadores, sob o risco de não cumprir tarefas usuais e ser considerado "antiquado" por muitos de seus colegas. Ou seja, é preciso educar-se tecnologicamente (GOHN, 2003).

O convívio com a tecnologia acontece neste nível mais superficial, em que indivíduos são "usuários", mas também em situações de pesquisas aprofundadas, quando atuam no 
desenvolvimento de programações digitais e equipamentos. Tais pesquisas resultam na formalização comentada mais acima neste mesmo capítulo, pois a digitalização abre um amplo campo de investigação relacionado com o som. A partir dos anos 1990, o controle sobre parâmetros do som, atuando em sua micro-estrutura, permitiu a compositores e pesquisadores sintetizar timbres e criar o que Barrière (1995) chamou de "famílias sonoras", ou seja, a manipulação de sons dando origem a novos sons.

... a possibilidade de não apenas esculpir [o som] "no exterior" (sua forma), mas também "no interior" (sua substância), e, desde que estamos falando de música, a habilidade de modificar sua estrutura temporal interna, comprimi-la, estendêla... Nunca antes compositores alcançaram tamanho controle sobre o som (BARRIÈRE, 1995: 16).

Muitas das descobertas neste "esculpir" do som aconteceram nos estúdios de música eletroacústica, em Colônia, Paris, Milão e Nova York, entre outras cidades, e posteriormente chegaram ao mercado comercial de instrumentos musicais na forma de sintetizadores. Com o custo acessível de equipamentos eletrônicos na atualidade, muitas das experiências que eram realizadas nos anos 50 de maneira precária e demoravam dias para serem processadas agora podem ser realizadas em qualquer residência, imediatamente. Há uma apropriação das tecnologias pelos músicos profissionais e amadores, interessados e apreciadores da música, sempre buscando novas formas de interagir com o material sonoro.

\subsection{Softwares educacionais e websites}

A junção da notação musical, da gravação sonora e das tecnologias digitais deu origem a sofisticados sistemas de ensino e aprendizagem da música. Diversos softwares foram elaborados para lidar com questões relacionadas à música, sendo acessíveis por meio de CDs (geralmente, quando são programas proprietários, que devem ser adquiridos) ou pela Internet (quando, muitas vezes, são oferecidos sem custos para o usuário). Para descrever os programas direcionados para a educação musical, os termos em inglês instructional software e computer-assisted instruction ainda são utilizados, mas technology-assisted instruction, ou "instrução baseada em tecnologia", cria uma categoria mais ampla, na qual podem se encaixar sites da Internet e diversos tipos de 
programas (WATSON, 2006).

A existência desses softwares transformou a vida de músicos e professores de música, com a simplificação de tarefas que antes exigiam jornadas de trabalho mais longas, investimentos financeiros mais altos e equipamentos menos acessíveis. Assim, o computador passou a ser uma peça fundamental na editoração de partituras (em programas como Finale, Sibelius e Encore); na produção de gravações (ProTools, Sonar, GarageBand, Logic, Cubase); no treinamento auditivo de aprendizes, entre outros exemplos.

Há de se ressaltar, como fez Bray (1997: 138), que “a compreensão musical, em oposição a conhecimento, raramente é aumentada com o uso de um CD-ROM sozinho". Se a utilização de recursos multimídia auxilia na transmissão de conteúdos, ela não assegura que esses conteúdos serão assimilados corretamente e irão contribuir para o desenvolvimento da musicalidade ${ }^{25}$. Essa questão remete à distinção entre treinamento e educação, apontada por Hodges (2001) como sendo central na utilização de tecnologias em ensino e aprendizagem de música. Segundo esse autor, o desenvolvimento de habilidades, que não pode ser confundido com a compreensão musical, muitas vezes é usado como único meio de avaliação da aprendizagem, pois é relativamente fácil de ser medido por observação direta.

Em muitos casos, os softwares funcionam apenas como ferramentas para a preparação de atividades, como na criação de uma partitura que será tocada pelo aprendiz. Em outros, o uso do software pode ser o elemento chave de uma tarefa, servindo como etapa que, se for parte de um processo, poderá resultar no aumento da musicalidade. O alerta dos autores citados acima tem como objetivo que o uso das tecnologias não seja uma finalidade, mas um meio, visando resultados interessantes ao desenvolvimento musical dos aprendizes.

Vários são os exemplos de situações em que softwares são úteis no estudo musical, considerando os produtos comercializados na forma de CD-ROM ou disponíveis sem custo na Internet $^{26}$. No treinamento auditivo, quando alunos aprendem os conceitos de grave e agudo e depois os refinam com a discriminação de intervalos, o computador age como um tutor incansável, sempre pronto a dar respostas. No estudo sobre um determinado artista, gênero musical ou período histórico, a transição entre texto, som e imagem enriquece os materiais que tradicionalmente foram usados. Em trabalhos envolvendo composição, é possível ouvir o

\footnotetext{
${ }^{25} \mathrm{O}$ termo musicalidade é considerado conforme a visão do educador David Elliot, que é discutida no capítulo 5.

${ }^{26}$ Nem todo CD-ROM produzido é vendido comercialmente, nem todo software disponível na Internet é gratuito. No entanto, por observação direta, é fácil constatar que essa é a regra para muitos dos casos.
} 
resultado de uma criação com a interpretação de uma orquestra ou qualquer outra formação de conjunto musical, sem que a partitura jamais deixe o computador $^{27}$. Na aprendizagem de performance, programas específicos servem como referência nos procedimentos necessários para tocar cada instrumento musical ${ }^{28}$. Todos esses são exemplos de situações em que, por meio de conteúdos sistematizados no computador, o aprendiz musical realiza tarefas que já existiam antes das tecnologias digitais. Mas, além dessas, novas atividades são possíveis com a utilização do computador.

O trabalho de Hodges (2001), baseado nos referenciais curriculares do Reino Unido, lista algumas dessas atividades em escolas britânicas. Por exemplo, o uso de softwares para explorar sons e idéias musicais, em que sonoridades diferentes e inusitadas são levadas para a sala de aula; o uso de programas de pintura (como o Microsoft Paint), para fazer "partituras gráficas" que tiram proveito das capacidades de produção dos computadores; o uso de seqüenciadores para produzir arranjos com timbres sintetizados; a conversão de arquivos sonoros (MIDI) em notação musical. Em todas essas alternativas, é destacada a metodologia de criar e salvar trabalhos, para posteriores edições e combinações com outras produções e atividades.

As funções de "arrastar e soltar", existentes nos programas de música com interfaces “amigáveis”, são citadas por Hodges (2001: 177) como vantagens para os alunos que não dominam a leitura musical tradicional, assim como o uso de samples e jingles pré-gravados, que podem ser combinados facilmente e promovem rápidos resultados ${ }^{29}$. A desvantagem, nesses casos, é que muitas vezes a proficiência do estudante em utilizar o software é mais perceptível do que o processo artístico que deu origem ao trabalho final. Em parte, esse problema resulta do fato de que muitos softwares foram desenvolvidos para contextos comerciais, não para servir a fins educacionais. Embora todo programa de música possa ter algum tipo de utilidade em processos

\footnotetext{
${ }^{27}$ Softwares de editoração de partituras apresentam recursos cada vez mais avançados para ouvir as notas escritas e trocar a seleção dos instrumentos utilizados. Produtos como Finale e Sibelius contam com um vasto banco de sons para a reprodução das partituras produzidas.

${ }_{28}$ Para o estudo do violão, por exemplo, existem os “dicionários de acordes" online, como o Chord Book (http://www.chordbook.com), o eMedia (http://www.emediamusic.com/freetools/chord.html), o All-guitar-chords (http://www.all-guitar-chords.com), entre muitos outros similares. Todos esses websites são oferecidos gratuitamente na Internet, assim como existem variações para o piano, mostrando a formação de acordes no teclado.

${ }^{29}$ Alguns programas, a exemplo do GarageBand, da empresa Apple, apresentam diversos loops e jingles com direitos autorais liberados, para que sejam usados livremente, em qualquer situação. Para produzir música, o usuário só precisa arrastar esses arquivos para dentro da interface, experimentar diferentes combinações, e aplicar efeitos do tipo reverberação ou delay. Em nenhum momento do processo é preciso lidar com a notação musical tradicional ou ter conhecimentos sobre instrumentos musicais.
} 
de ensino e aprendizagem, os programas educacionais são direcionados especificamente para essa finalidade, apresentando características ideais.

Tal diferenciação nos leva a algumas indagações: quando é possível (ou desejável) usar softwares "não educacionais" na educação musical? E quando é preciso criar um novo programa, mais adequado a situações específicas de aprendizagem? Algumas pesquisas no Brasil têm resultado em propostas de softwares, como mostram alguns itens da lista compilada por Krüger (2006), reunindo trabalhos envolvendo tecnologia e educação musical. Ao mesmo tempo em que não se deve reinventar a roda constantemente, criando programas muito similares aos que já existem, é importante que os mesmos sejam adaptados para a realidade dos aprendizes brasileiros. A maioria dos softwares estrangeiros é produzida em inglês, o que inviabiliza sua utilização por grandes parcelas da população do Brasil. Por esse motivo, é preciso contar com explicações para as atividades em português. Além disso, é preciso sempre avaliar os benefícios desses programas sob o ponto de vista pedagógico. Esforços nesse sentido, estabelecendo parâmetros para testes e avaliações, já foram realizados por pesquisadores brasileiros (KRÜGER, 2000 e CONSANI, 2003), e indicam o caminho das pedras para o desenvolvimento de novas propostas.

Os custos proibitivos e a dificuldade tecnológica certamente são fatores complicadores na produção de softwares para a educação musical. Quando não há verbas para a aquisição ou para o desenvolvimento de programas específicos, outras alternativas são viáveis, desde que haja uma capacitação dos professores e acesso a recursos mínimos ${ }^{30}$. Enquanto computadores, teclados eletrônicos e demais recursos de hardware têm tido seus custos reduzidos ao longo dos anos,

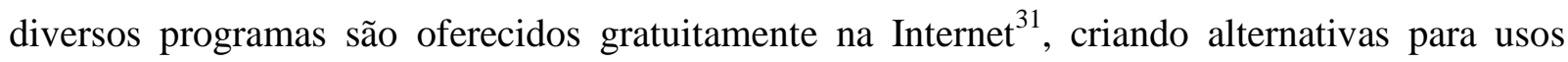
educacionais em escolas e projetos educacionais ${ }^{32}$.

Mas, como sugerem Mills e Murray (2000), a existência de tecnologias nas escolas não é garantia de sucesso no ensino. Segundo esses autores, práticas de "bom ensino" podem ser observadas desde a popularização dos computadores pessoais, durante a década de 1990, com o

\footnotetext{
${ }^{30}$ Podemos considerar como "recursos mínimos" um computador conectado à Internet, com microfone e caixas acústicas. Com esse equipamento, é possível editar partituras, produzir gravações e ouvi-las.

${ }^{31}$ Exemplos que podem ser citados são os softwares de gravação Audacity (http://audacity.sourceforge.net), e de notação musical Noteflight (http://www.noteflight.com) e MuseScore (http://www.musescore.org).

${ }^{32}$ Diversos projetos de Organizações Não-Governamentais (ONGs) estão baseados no ensino de música e de informática, constituindo um campo fértil para experiências com softwares gratuitos de música em usos educacionais. Entre os exemplos que podem ser citados, estão os projetos dos Meninos do Morumbi (http://www.meninosdomorumbi.org.br) e do Bate-Lata (http://www.ongpaulofreire.org.br/bate.htm).
} 
uso de seqüenciadores para silenciar ou destacar canais e assim isolar elementos na escuta musical; com seqüências programadas sobre as quais alunos praticam a improvisação musical; ou em exercícios de criação musical em que alunos gravam suas performances e as reconstroem em programas de edição sonora. Por outro lado, também são várias as "armadilhas" para um professor não preparado ${ }^{33}$.

Entre essas armadilhas, está o risco de formar especialistas em apertar teclas do computador, mas sem nenhuma compreensão musical e sem capacidades para interpretar, criar ou improvisar música. A facilidade de manipulação sonora com o computador fez emergir questões que não existiam quando os principais recursos tecnológicos relacionados ao estudo musical estavam limitados à notação e à gravação: as mesmas tecnologias poderão tanto aproximar indivíduos do aprendizado, abrindo caminhos para a compreensão musical, como afastá-los, se de alguma forma houver a sugestão de que não é preciso estudar música para realizar produções musicais significativas. A tarefa dos professores de música é fazer a balança pender para o lado que favorece a educação musical, usando os softwares como meio de acesso, e não como destino final.

Existindo esse compromisso com o desenvolvimento da musicalidade dos alunos, poderá ocorrer um aproveitamento bastante frutífero do acervo de softwares musicais existente. A lista de websites e programas educacionais compilada no trabalho de Watson (2006) é representativa das possibilidades nessa área, incluindo itens produzidos com finalidades educacionais em teoria musical, treinamento auditivo, composição, performance, apreciação musical, história da música e estudos de improvisação. A essa lista, são somados os softwares que desenvolvem funções e complementos direcionados para a aprendizagem de instrumentos ou de canto, como o SmartMusic ${ }^{34}$. Programas que alteram o tempo de músicas sem modificar as alturas das gravações (ou o inverso) ${ }^{35}$ também servem como exemplos, assim como sites que oferecem

\footnotetext{
33 Mills e Murray (2000) relataram as práticas de "bom ensino" e as "armadilhas" constatadas nas visitas de inspetores do Office for Standards in Education (OFSTED) a 52 escolas na Inglaterra, entre dezembro de 1997 e março de 1998, quando foram assistidas 195 aulas de música. Um dos pontos positivos observados nessas visitas, já naquela época, foi o tráfego de atividades musicais entre as escolas e as casas dos alunos, possível porque muitos pais adquiriam equipamentos para uso nas residências e algumas escolas tinham materiais que os estudantes podiam emprestar.

${ }^{34} \mathrm{O}$ SmartMusic (http://www.smartmusic.com ) é um programa que possibilita aos estudantes tocar ou cantar em um microfone conectado ao computador, seguindo o cursor que guia a execução da música notada na tela. Em seguida, o software indica as notas que foram tocadas de forma correta e incorreta, mostrando erros de ritmos e alturas, e produz uma avaliação, baseada no percentual de acertos.

${ }^{35}$ O exemplo citado é o Amazing Slow Downer, produzido por Roni Music (http://www.ronimusic.com).
} 
gratuitamente milhares de arquivos $\mathrm{MIDI}^{36}$, que podem ser abertos em programas de notação musical.

Também são relevantes as contribuições dos programas de produção musical, para editar arquivos sonoros ou combiná-los em gravadores multi-pistas. Nos softwares de edição de áudio ou de gravação digital, é comum ter a visualização das ondas sonoras em gráficos que representam eixos de tempo em relação à energia sonora. Dessa forma, é possível "ver o som", com grandes benefícios para a educação musical. A compreensão da música é facilitada com esse elemento, já que se pode relacionar diretamente o fenômeno sonoro com o princípio físico que o causou. Esse é um exemplo em que softwares com finalidades não educacionais podem ser usados para facilitar o estudo da música.

Todas as tecnologias mencionadas neste capítulo (notação musical, registro sonoro, tecnologias digitais, softwares educacionais e websites) compõem os meios de comunicação musical que tornam a educação musical a distância possível. Com esses elementos, processos educacionais podem acontecer sem a presença de professor e aluno em um mesmo espaço, no mesmo instante. Diversas questões surgem a partir dessa realidade, como será colocado a seguir.

\footnotetext{
${ }^{36}$ Um dos websites com acervos dessa magnitude é o Classical Music Archives (http://www.classicalarchives.com).
} 


\section{Questões sobre música e EAD}

\subsection{Informação e aprendizagem}

Conforme foi colocado no capítulo 2, a história da educação a distância exibe organizações curriculares de cursos desde o século XIX, avançando de acordo com as possibilidades tecnológicas disponíveis em cada época subseqüente. Continuamente, nota-se uma preocupação em integrar as tecnologias da comunicação nos processos educacionais, quebrando barreiras geográficas para que conteúdos cheguem até aqueles interessados em aprender. A história da educação musical a distância, da mesma forma, apresenta inovações constantes nos meios para difundir conteúdos musicais, especialmente após o surgimento dos meios de gravação, também ainda no século XIX. No entanto, a estruturação de cursos curriculares de música, com professores que acompanham e avaliam o desenvolvimento de seus alunos a distância, é um acontecimento que apenas recentemente ganhou força, estimulado pela expansão da Internet. O que se percebe nas décadas anteriores são experiências de EAD isoladas, frutos da iniciativa de instituições inovadoras e ousadas, como o Open University, no Reino Unido.

Antes da Internet, outras tecnologias serviram como ferramentas importantes na educação musical presencial. Com a crescente facilitação no uso dessas tecnologias, cada vez custando menos e com interfaces mais simples, parcelas cada vez maiores da população mundial conseguem utilizá-las. Uma invenção que é difícil de compreender ou de aplicar não é considerada completa, transformando o termo user-friendly quase que em um requisito obrigatório. Com essas facilidades, mesmo antes dos computadores e das redes eletrônicas (mas principalmente após a chegada deles), as tecnologias causaram aumentos significativos na quantidade de informações em circulação no planeta.

Para muitos autores, com mais informação disponível, menor é a atenção dada ao que existe. Neil Postman, um dos mais críticos, faz a seguinte colocação:

A informação transformou-se em uma forma de lixo, não apenas incapaz de responder as questões humanas mais fundamentais, mas também pouco útil em fornecer direções coerentes para a solução dos problemas mais mundanos (POSTMAN, 1993: 69). 
Para Glenn Gould, dentro de tal contexto, "a música se tornou uma influência penetrante em nossas vidas, e enquanto nossa dependência dela tem aumentado, nossa reverência, em certo sentido, diminuiu" (Gould, 2004: 116). Segundo essa forma de pensar, o ser humano está se acostumando a permanecer imerso em um continuum musical, mas sem prestar a devida atenção aos sons que o cercam.

Por outro lado, pesquisadores como Frank Biocca beiram o otimismo exagerado, colocando as novas tecnologias como pontos que demarcam uma evolução sem efeitos colaterais negativos. Por exemplo, segundo esse autor:

O fonógrafo e o rádio participaram no processo de mudança musical preparando platéias, músicos e compositores para novas formas de experiências auditivas, alterando as sensibilidades em favor de uma maior atenção cognitiva na escuta, e também difundindo novos experimentos sonoros (BIOCCA, 1988: 67).

Diante de posturas tão divergentes, fica configurado um mundo tecnológico em que as comunicações são extremamente facilitadas, seja este um fato considerado positivo, causando uma ampliação da capacidade de atenção, ou negativo, gerando o caos em meio a informações descontextualizadas. De qualquer maneira, são as tecnologias de comunicação, juntamente com todas as formas de tratamento do material musical mencionadas no capítulo anterior, que possibilitaram a criação de programas de educação musical a distância. Na medida em que tais tecnologias são acessíveis a mais indivíduos, aumentam os canais de interlocução entre professores e alunos. Logicamente, não haveria sentido para uma instituição organizar cursos a distância se alunos em potencial não pudessem utilizar as ferramentas que viabilizam o processo educacional.

Nos primórdios da EAD, quando apenas o correio conectava professores e alunos, a aprendizagem ocorria de forma independente, pois havia uma baixa interatividade para discussões e resoluções de dúvidas diretamente com os mestres. A interação essencial acontecia com o material educacional, pois o longo tempo de espera e a limitação nas comunicações dificultavam contatos e inviabilizavam conversas de duas vias. Posteriormente, os avanços tecnológicos criaram condições para que a aprendizagem se tornasse colaborativa, com interações constantes entre todos os envolvidos nos processos educacionais. Não somente professores e alunos passaram a examinar conjuntamente os conteúdos estudados, mas também os alunos 
puderam debater sobre suas experiências e requisitar participações externas para enriquecer suas discussões. Como Thorpe (2002: 147) coloca, houve uma passagem da aprendizagem independente para a colaborativa, mas atualmente há uma combinação das duas, com uma simples mudança de software no computador: a colaboração acontece por meio de mensagens eletrônicas, fóruns e outras formas de comunicação síncrona ou assíncrona; a aprendizagem independente via o acesso a recursos disponíveis na Internet. Com essas alternativas, Moran (2002) observou uma adaptação a ritmos diferentes, pois na pesquisa individual cada aluno trabalha no seu próprio esquema, e na pesquisa em grupo a aprendizagem deve acontecer com a combinação dos ritmos de todos os alunos participantes.

Thorpe (2002) aponta que, quando as comunicações eram mais raras, o contato com o outro servia para dar suporte para a aprendizagem independente, auxiliando os aprendizes em questões muitas vezes intransponíveis sem direcionamento externo. $\mathrm{Na}$ atualidade, a ênfase do estudo independente é sustentar as interações em grupo, criando subsídios para a participação dos indivíduos nos trabalhos colaborativos. O mesmo pode ser constatado na área musical, já que um aprendiz isolado geograficamente, sem condições de se comunicar com professores ou outros aprendizes, no passado podia interagir apenas com os materiais educacionais a que tivesse acesso. Isso era comum, por exemplo, com o formato play-along, em que um músico toca com uma gravação que simula o acompanhamento de outros músicos. Não há respostas desse acompanhamento às escolhas feitas pelo aprendiz ou observações sobre a sua performance. No máximo, um livreto indica algumas das opções que são usualmente utilizadas em relação aos ritmos, escalas para improvisação ou combinações de acordes para harmonização. Com as tecnologias de comunicação atuais, esta situação muda, pois é possível obter feedback sobre o estudo independente em discussões online colaborativas. Neste sentido, o estudo individual contribui para que as discussões em grupo sejam produtivas e frutíferas.

Porém, se virtualmente o planeta inteiro pode ser alcançado por comunicações via Internet, um empecilho surge tanto nos estudos independentes como colaborativos. Para usufruir amplamente dos recursos disponíveis na rede, é preciso dominar a língua inglesa, usada como base na maioria dos cursos ministrados a distância e nos recursos para consultas online. Um indivíduo que compreende exclusivamente o português encontra limitações para realizar pesquisas nesse meio. Como Litto (2008b) destacou, a língua portuguesa é falada por quase 250 
milhões de pessoas atualmente, mas a maioria vive em países relativamente pobres, o que explica porque menos de $1 \%$ de toda a informação na Internet está em português.

O inglês é freqüentemente apresentado como uma língua internacional neutra, sem ligação com quaisquer contextos culturais, mas como Mayor e Swann (2002) indicam, a interpretação de palavras sempre ocorre de acordo com as culturas locais. Como exemplo, as autoras citam as dificuldades encontradas por professores da Open University, no Reino Unido, que sugerem ações para os alunos de forma leve e delicada, em frases do tipo you might like to think about doing this (talvez você goste de pensar sobre fazer isso). Tal delicadeza muitas vezes é interpretada em outros países como uma sugestão que não precisa ser seguida, enquanto na realidade trata-se de uma tarefa considerada obrigatória pelos professores. Além da educação recebida pelos britânicos, essa maneira de propor atividades revela a preferência da Open University por palavras não definitivas, como appears e suggests, lidando com o conhecimento não como fixo e absoluto, mas produzido e avaliado por pesquisas. Outras instituições, como a Indira Gandhi National Open University, segundo Mayor e Swann (2002), demonstram predileção por termos como found e revealed, muitas vezes colocando as idéias de forma mais direta e rígida.

No campo musical, em muitos casos a avaliação de alunos envolve críticas a suas performances e composições, e observações que são concebidas normais e impessoais em uma cultura poderão ser tidas como rudes e ofensivas em outros países. Uma nota baixa para uma obra apresentada como trabalho final de um curso, se teve como objetivo a indicação de falhas e o estímulo para melhorias, poderá ser recebida como uma mensagem cruel, simplesmente apontando falta de talento. Portanto, mesmo que uma língua comum sirva na conexão de professores e alunos, o suporte a estudos realizados a distância deve manter em foco a origem dos interlocutores, de alguma forma prestando um feedback sobre os trabalhos realizados que seja específico para a situação determinada. Na aprendizagem musical, assim como em cursos de inglês como segunda língua, tão importante quanto indicar problemas e estratégias para corrigilos é estimular o aprendiz a continuar seus esforços rumo aos objetivos traçados (HYLAND, 2001). Sem considerar o contexto da avaliação, uma escolha de palavras equivocada pode obter resultados inversos aos pretendidos. 


\subsection{Suporte aos alunos}

As pesquisas sobre EAD oferecem várias definições para o termo em inglês learner support, descrevendo os processos nos quais há um auxílio para atender necessidades de estudantes a distância. Esse auxílio pode ser administrativo, direcionado a matrículas e pagamento de mensalidades; e acadêmico, oferecendo diferentes formas para a resolução de dúvidas e explanações sobre os conteúdos dos cursos. A definição mais ampla de "suporte ao aluno" engloba todas as ações de uma instituição no sentido de apoiar os estudos de seus alunos, baseadas nos materiais pedagógicos produzidos para as disciplinas oferecidas. Além de focar os conteúdos, também se espera que haja uma ajuda na organização da vida acadêmica, com orientações no planejamento do tempo disponível para o estudo, na escolha dos próximos cursos e na preparação para exames e avaliações.

Desde o surgimento da Open University, no Reino Unido, no final da década de 1960, essa instituição tem servido como modelo para a criação de outras universidades similares, no que tange o suporte oferecido aos seus alunos, colocando tutores como guias acadêmicos dos cursos. O tutor assinala as tarefas a realizar, fica disponível por diversos meios para a resolução de dúvidas e organiza encontros presenciais que, ao menos na universidade britânica, os alunos são encorajados, mas não obrigados, a freqüentar. Embora existam evidências de que muitos alunos escolhem cursos que não exigem encontros presenciais exatamente por este motivo (MASON, 2003), e uma extensa lista de cursos realizados completamente online possa ser encontrada na Internet, a presença física dos tutores em momentos pontuais tem se mostrado extremamente importante.

Estudos com alunos da Open University realizados durante quase trinta anos continuam mostrando que estudantes valorizam os tutoriais face a face, requerem mais deles sempre que são perguntados, reclamam quando tutoriais online são considerados substitutos para encontros face a face, escolhem o facea-face como o método preferido de interagir com seus tutores, e consideram os tutoriais face a face como uma parte importante do curso (MASON, 2003: 91).

Inicialmente, a Open University tinha um "sistema de aconselhamento", que fornecia acompanhamento educacional, mas não era específico para cada um dos cursos. O conselheiro de um determinado aluno era o mesmo durante todo o período de estudos, proporcionando uma 
continuidade mantida acima dos tutores específicos dos cursos, que mudavam a cada ano. Depois, esse sistema foi substituído, por motivos ligados principalmente ao controle de gastos em tempos de expansão, por um modelo em que o suporte ao aluno é dado mais significativamente pelos tutores, auxiliados por assistentes disponíveis em centros regionais. O contato mais próximo ocorre somente entre alunos e tutores, já que os assistentes trabalham de maneira anônima em call centers, sem estabelecer relacionamentos pessoais. No período de estabelecimento da universidade, havia 13 centros regionais dando apoio para 260 centros de estudo, onde alunos e tutores se encontravam (TAIT, 2003).

$\mathrm{Na}$ Universidade Aberta do Brasil, assim como em outros sistemas de ensino baseados na EAD, o professor é um "supervisor geral do processo de ensino". Ele é responsável pela elaboração dos conteúdos, junto com uma equipe técnica para desenvolver os materiais pedagógicos, e depois coordena o trabalho dos tutores no oferecimento das disciplinas ${ }^{37}$. Depois que um curso começa, sua participação ocorre em alguns momentos, dirigindo as atividades e respondendo dúvidas sobre os conteúdos estudados. Em muitas questões, os alunos obtêm respostas com seus colegas, com os tutores, ou nos meios eletrônicos, tirando do professor a imagem de "dono exclusivo do conhecimento".

Diversos estudos indicam a necessidade de que os professores assumam um novo papel, não apenas na EAD como também na educação em geral. Autores dizem que o professor deve ser um "parceiro do aluno na construção do conhecimento" (BELLONI, 2001), um "orientador / mediador" (MORAN, 2002), um “coordenador" (CAJAZEIRA, 2004), e colocam a necessidade de que seja um "facilitador de aprendizagens individuais e colaborativas" (OLCOS, 2007). Suas novas tarefas incluem:

aconselhar estudantes sobre como identificar e gerenciar problemas do mundo real mais do que exercícios baseados em livros-texto, como buscar, selecionar e avaliar fontes de informação, e como documentar e comunicar seus resultados para que outros os acessem facilmente e possam reutilizá-los (OLCOS, 2007: 40).

Para Pedro Demo (2002: 217), o termo “facilitador" não é positivo, pois representa alguém que mastiga as coisas de antemão, um "fabricador de receitas". Esse autor destaca que, no

\footnotetext{
${ }^{37}$ Essas duas tarefas (elaboração de conteúdos e acompanhamento de disciplina) também podem ser realizadas por dois professores distintos. Na UAB - UFSCar, usualmente o mesmo profissional cuida das duas funções.
} 
Japão, é proibido facilitar a aprendizagem no sentido de encurtar, abreviar e simplificar, e sugere que seria mais apropriado usar a figura do professor no romance "O Mundo de Sofia", escrito por Jostein Gaarder, que nunca dá nada pronto, sabe deixar o aluno perdido quando necessário, e sempre lança perguntas e desafios. Tal imagem está de acordo com a função do professor da UAB, que planeja "pontos de apoio" para os caminhos que os alunos irão percorrer. As comunicações mais constantes, orientando o dia-a-dia das tarefas, são de responsabilidade dos tutores.

No entanto, durante muito tempo, na literatura sobre EAD o papel do tutor foi colocado simplesmente como "corretor de provas", como se suas atividades fossem somente de feedbacks não educacionais (LENTELL, 2003). Esta noção começou a mudar por diversos fatores citados por Lentell (2003: 68-72), entre os quais está a crescente comercialização da educação a distância. Alunos passaram a ser clientes, cursos e materiais de ensino são produtos e o suporte à aprendizagem é um serviço. Segundo Tait (2003), esta visão é problemática, pois se instituições como universidades têm a autoridade para outorgar certificados, o cliente não pode sempre ter razão ou ter sempre o que deseja. De qualquer forma, as instituições educacionais devem responder às expectativas de um mercado que vê o aluno no papel de consumidor, colocando em posição estratégica aqueles que lidam diretamente com os estudantes. Afinal, "é apenas para o tutor que o aprendiz a distância existe como um indivíduo" (LENTELL, 2003: 73).

Em uma nova concepção, espera-se que o tutor seja pró-ativo e não apenas reativo, com um conhecimento profundo da sua área de atuação. Nesse sentido, ele é um recurso educacional tanto quanto os materiais de estudo. Enquanto existem os professores conteudistas, ou seja, aqueles que selecionam e preparam textos, gravações de áudio e vídeo, objetos de aprendizagem e links para recursos adicionais, são os tutores que lidam com questionamentos e problemas propostos pelos alunos, tendo que justificar os currículos determinados até quando são divergentes de suas experiências pessoais. Como Mason (2003) afirma, mesmo que a área de tarefas automatizadas na Internet esteja em desenvolvimento, o comentário individual dos tutores certamente é uma das formas mais significativas de personalizar um curso.

Ainda segundo Mason (2003), no futuro esse modelo poderá não mais ser necessário ou apropriado, pois o contato virtual e o feedback dado por máquinas não mais terão a associação pejorativa da atualidade, se comparados às avaliações realizadas por tutores. Apesar da 
importância dos tutores na EAD observada nos parágrafos acima, outros pesquisadores também indicam caminhos em que se vê uma ausência da necessidade de tutoria humana no futuro. Anderson (2004) fala do perigo em assumir que todas as interações humanas podem ser substituídas por interações com máquinas, especialmente quando se trata de serviços envolvendo relações de afetividade, como aquelas entre professores e alunos. Entretanto, segundo este mesmo autor, também há um perigo em ignorar o potencial para melhorar a qualidade e diminuir os custos destes serviços, ao se afirmar que as interações humanas são sempre necessárias. Ao contrário daqueles que vêem a automatização como negativa, Anderson (2004: 95) visualiza "um meio para continuar a evolução e a democratização da educação, passando de um recurso exclusivo dos ricos para um que está aberto a todos", e acredita que aprendizes do futuro "ficarão mais confortáveis e terão maiores expectativas com o imediatismo de serviço disponível 'em qualquer lugar / a qualquer hora', que realisticamente só pode ser obtido a custos acessíveis com máquinas" (2004: 97).

Embora os autores citados indiquem a ausência de tutores como uma tendência para o futuro, isso já ocorre nos dias presentes. Litto (2008a) aponta a University of Southern Queensland, na Austrália, como exemplo de instituição que oferece, com sucesso, o aprendizado via Internet totalmente automatizado ${ }^{38}$. A menos que o aluno deseje, em alguns dos cursos online daquela universidade não é preciso entrar em contato direto com outros humanos, pois cursos completos podem ser estudados apenas com interações com o computador. Sistemas como este não são permitidos pela atual lei educacional do Brasil, onde o componente face a face entre alunos e tutores é obrigatório, incluindo avaliações realizadas presencialmente. Litto (2008a) destaca que esta exigência nega uma das maiores virtudes da educação a distância, impedindo a eliminação de barreiras de tempo e distância e impossibilitando que estudantes adquiram conhecimento e qualificações em regiões que não as suas próprias.

Um exemplo claro em que o feedback automatizado apresenta vantagens sobre as correções de um humano é o treinamento auditivo realizado com softwares de música, pois a máquina jamais se cansa de realizar exercícios e apontar erros. $\mathrm{O}$ acesso à Internet possibilita a utilização de websites como o Musictheory.net (http://www.musictheory.net) para aprender a

\footnotetext{
38 A University of Southern Queensland (http://www.usq.edu.au) oferece vários cursos de música a distância, incluindo bacharelados e mestrados. Esses cursos não são completamente automatizados, mas contam com o USQConnect, um sistema de ajuda online com um banco de perguntas e respostas já realizadas, prestando auxílio ao aluno tanto em questões administrativas como em outras relacionadas aos conteúdos dos cursos.
} 
teoria e praticar a percepção de intervalos, escalas e acordes, em um aprendizado que está subordinado à repetição contínua de exercícios para identificar diferenças entre a sonoridade de cada exemplo estudado. No passado, para a realização desta atividade era preciso utilizar um instrumento musical, usualmente o piano, para que sequiências de notas fossem tocadas e o aprendiz tentasse reconhecer os sons, associando-os aos conceitos teóricos. Com o computador, é possível praticar ditados rítmicos, melódicos e harmônicos sem o auxílio de outro indivíduo, tornando o estudo autônomo e mais simples.

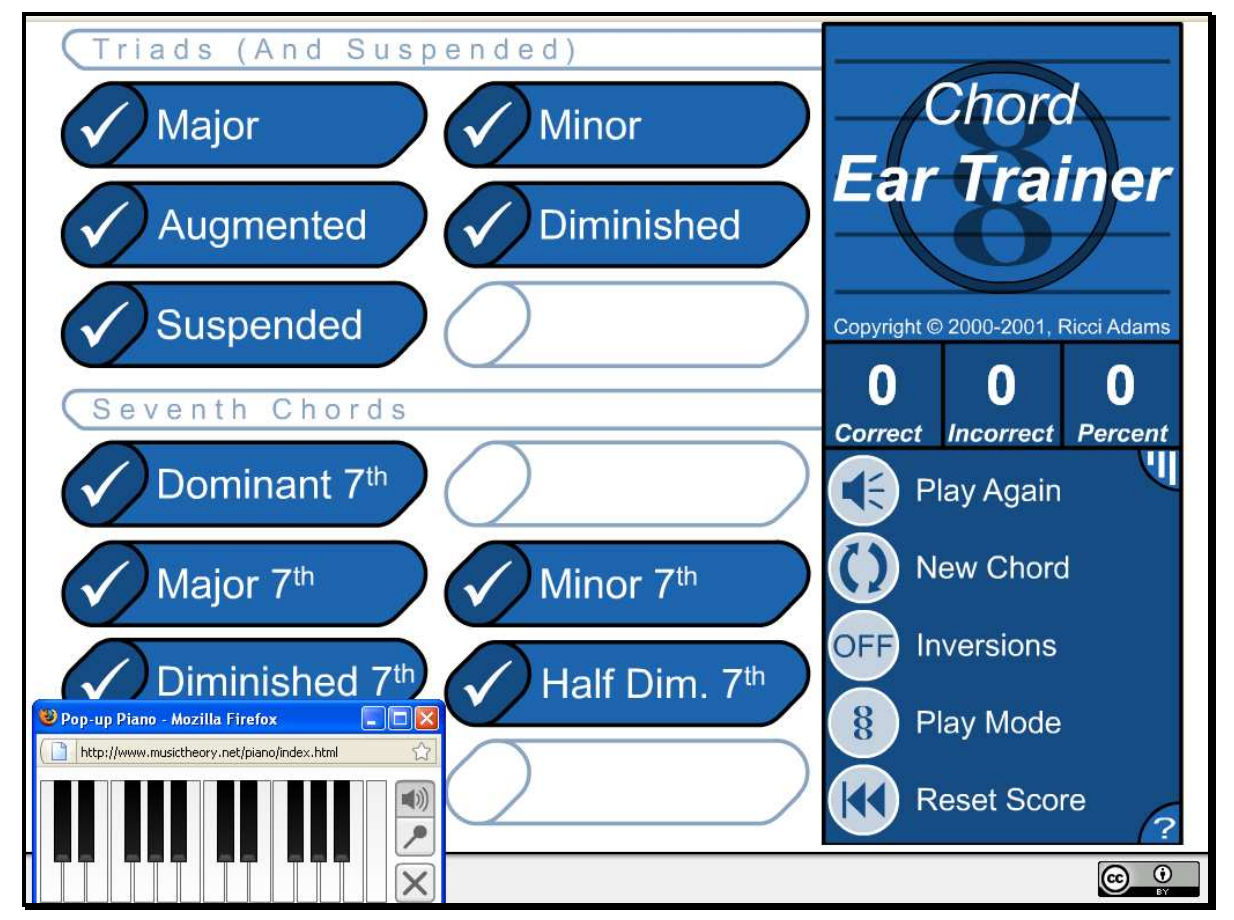

Figura 1: website do Musictheory.net

Questões musicais que podem ser tratadas com explicações matemáticas, como a construção de escalas, são bem demonstradas em sistemas automatizados. Por exemplo, objetos de aprendizagem podem explicar as relações entre tons e semitons na escala maior, com diferentes formas de visualização e recursos de áudio, respondendo aos controles dos alunos. O estudo e a avaliação da aprendizagem são facilitados e, para um tutor bem preparado, a indicação de websites aos alunos é uma alternativa para trabalhar com esta área. Nesses casos, não há associação pejorativa, já que há bastante tempo os softwares de música são utilizados 
informalmente pelos aprendizes, seja online ou em CD-ROM, e o tipo de resposta que é dada aos exercícios realizados é adequado. Com perguntas cuja resposta é sim ou não, pode-se avaliar a compreensão de explicações teóricas e a capacidade de identificar intervalos e acordes, ao contrário das áreas do estudo musical em que muitas variáveis estão envolvidas. A aplicação dos intervalos e acordes na música, as relações entre os sons e seus significados, e a reflexão necessária a uma compreensão musical profunda apresentam questões mais complexas, que demandam sistemas de ensino mais elaborados.

Anderson (2004) observa que muitos alunos terão a mesma preferência por serviços automatizados na educação que têm por caixas automáticos em bancos. Em muitas situações, um erro humano é mais provável do que uma falha da máquina, já que uma tarefa repetida ao extremo favorece a perda da concentração e o desvio da atenção para assuntos externos. Por este motivo, além de alguns dos exercícios de treinamento auditivo, também existem casos de sucesso na informatização de diversos procedimentos administrativos, como matrículas e validação de créditos, tanto em instituições de ensino a distância como presenciais. Neste campo, percebe-se uma tendência progressiva para a diminuição de contato com atendentes humanos, bastando a interação entre estudante e máquina para encaminhar a maioria das questões que se fazem necessárias.

Por outro lado, também ocorre um aumento de contatos humanos por meio das máquinas. Como será exposto a seguir, as comunidades virtuais são elementos importantes na educação a distância.

\subsection{Comunidades virtuais}

\footnotetext{
... na educação musical a distância a colaboração entre pares é de grande valor. Por não haver os contatos ordinários, que na educação presencial acontecem regularmente, há uma busca maior de trocas de idéias e de valores entre os alunos de um grupo determinado, criando um envolvimento muito grande entre eles, trazendo aprendizagens, e, além disso, fortalecendo a motivação (SoUZA, 2003: 60).
}

Segundo o que foi colocado no final da seção anterior, nem sempre a participação direta de um tutor é indispensável para resolver problemas de alunos. No entanto, não é difícil imaginar situações em que respostas automatizadas não são tão eficazes quanto aquelas dadas por colegas 
ou professores. Por exemplo, um estudante desenvolvendo a técnica instrumental ao piano poderá estar insatisfeito com seu desempenho ao executar escalas, porque após um determinado período de estudos não consegue progredir para andamentos mais rápidos no metrônomo. Provavelmente, o maior alento para este indivíduo viria de outros alunos, comentando que enfrentaram o mesmo problema e depois de muita persistência chegaram a seus objetivos. Aqui, o recurso tecnológico funciona apenas se utilizado como meio de conexão para redes sociais de apoio cognitivo e afetivo. Este apoio poderá ser encontrado com colegas e tutores atuais ou, em parte, com pessoas que postaram suas idéias na Internet muito tempo antes.

\begin{abstract}
A net permite que conversações sejam digitalizadas, armazenadas e reproduzidas quando necessário. Este tipo de continuidade pode ser usado para criar interações entre estudantes que transpõem não apenas espaços geográficos, mas também temporais. Assim, é possível para alunos aprender, retomar e contribuir com conversações que ocorrem durante muitos meses ou mesmo anos (ANDERSON, 2004: 101).
\end{abstract}

As perguntas e respostas postadas em fóruns criam um sistema de informação imediata, que depois permanece como um acervo online de dúvidas resolvidas. Uma pergunta formulada em mecanismos de busca como o Google usualmente apresenta entre os resultados discussões ocorridas meses ou anos antes, muitas vezes com respostas exatas para as indagações atuais. No exemplo do estudante pianista, a questão "como tocar escalas no piano" o conduziria não somente a websites oferecendo aulas online, mas também a diversas postagens em fóruns. A escolha de palavras mais específicas poderia refinar esta pesquisa, ou buscas em outras línguas ampliariam o leque de respostas obtidas, até que uma frase de interesse fosse encontrada.

Pesquisas na Internet certamente podem apresentar a resolução de dúvidas, mas não criam um sentimento de pertencimento. Kember (2007), em suas investigações com alunos da Open University of Hong Kong, identificou quatro focos de origem para este sentimento: a classe ou colegas da turma, os tutores e professores, o departamento em que o curso era realizado, e a universidade, sendo que a sensação mais forte apontou para a classe ou o grupo. Os resultados indicaram que o mecanismo mais efetivo para o desenvolvimento de afinidades na turma foi o arranjo de atividades promovendo discussões e trabalhos em grupo para que os alunos se conhecessem. 
O contato humano do sistema de suporte acadêmico oferece uma oportunidade clara para aumentar o senso de coletividade (...). O elemento afetivo de um bom tutorial parece ser tão bom para desenvolver um senso de coletividade quanto eventos sociais, se não for melhor. Amizades podem surgir, mas ainda mais por meio de experiências de estudo coletivo do que em eventos especificamente devotados à socialização (KEMBER, 2007: 147).

O acontecimento de cunho puramente social, quando alunos, tutores e professores reúnem-se para conversar e debater idéias não necessariamente relacionadas aos assuntos do curso em que estão envolvidos, é importante para o conforto emocional de todos, pois também contribui para criar uma sensação de unidade. Entretanto, em estudos realizados predominantemente a distância, com raros encontros presenciais, a pesquisa de Kember (2007) comprovou que os estudantes valorizavam mais o tempo coletivo direcionado para as atividades de tutoria e discussões sobre os conteúdos do curso.

Transpondo as colocações de Kember para o estudo da música, percebe-se que o sentimento de pertencimento pode surgir não apenas em trocas de idéias verbais, mas principalmente em atividades presenciais como a construção de instrumentos musicais ou realizações musicais conjuntas. Assim como a verbalização de idéias pode gerar intercâmbios acerca de teorias e experiências práticas, a execução de uma peça musical por um grupo de alunos representa um elemento de aprendizagem essencial, ao mesmo tempo em que são criadas afinidades e afeições entre os membros da turma. Em um curso sobre instrumentos de percussão, como será discutido nos capítulos 6 e 7, a participação em realizações musicais em grupo faz com que alunos aprendam a partir do conhecimento do outro, tanto na demonstração de suas soluções para questões técnicas, como na oferta de uma base sonora para experimentações rítmicas que contribuem rumo à formação de linguagens musicais individuais. Enquanto o estudo separado de cada instrumento de percussão é importante, é com a junção de vários instrumentos que seus possíveis papéis ficam claros aos estudantes, que estabelecem ligações afetivas ao darem suporte uns aos outros. Alguns irão ocupar espaços com notas graves e longas, outros com notas agudas e curtas, e o enlace destes extremos, juntamente com todas as outras possibilidades intermediárias, dá ao grupo o sentimento de coesão que, oportunamente, se transforma em pertencimento.

O pertencimento também é a marca das comunidades virtuais. A definição de Rheingold (1993), popularizada no final do século XX, é uma referência importante no estudo das novas formas de sociabilidade que surgiram com as redes eletrônicas, possíveis com interações 
síncronas e assíncronas entre indivíduos situados em qualquer região do planeta conectada à Internet.

\begin{abstract}
As comunidades virtuais são agregados sociais surgidos na Rede, quando os intervenientes de um debate o levam por diante em número e sentimento suficientes para formarem teias de relações pessoais no ciberespaço (RHEINGOLD, 1993: 5).
\end{abstract}

Rheingold foi específico ao colocar que as comunidades virtuais surgem na rede, mas o termo acabou por ter seu uso generalizado para outras formas de interação, incluindo relações que começaram em encontros presenciais e tiveram continuidade via comunicações eletrônicas. Alguns autores, a exemplo de Salavuo (2006: 254), pensam que as palavras comunidade online seriam mais adequadas para designar muitas dessas situações, pois se trata de uma comunidade estabelecida no mundo real (e não virtual), que mantém ligações por meio da Internet. Para Demo (2002), o virtual é simplesmente um dos patamares da realidade e, nesse sentido, "não é falta de presença, mas outra forma de estar presente" (DEMO, 2002: 216).

De qualquer maneira, a utilização da palavra "comunidade" denota uma valorização das interações possíveis com as redes de computadores, reconhecendo a Internet como meio viável para chegar ao sentimento de pertencimento a um grupo. Para a educação a distância, essa possibilidade vem contra a idéia de isolamento dos alunos, separados de seus colegas e professores por telas de monitores. Pelo contrário, eles estão juntos por meio de seus computadores, criando um ambiente em que potencialmente todos aprendem a partir de todos. A situação de isolamento lembra a descrição de Christopher Small para a "sala de aula ortodoxa", onde o conhecimento passado de aluno para aluno recebe o nome de "cola" (SMALL, 1996: 185).

A observação da chamada Geração Net, ou seja, alunos nascidos durante a década de 1980 ou depois, revela que suas interações online são emocionalmente abertas, com ampla aceitação de diversidades, diferenças e compartilhamentos (OBLINGER e OBLINGER, 2005). Nesse contexto, é natural buscar auxílio na Internet para qualquer questão, seja de caráter afetivo ou sobre conteúdos de um curso, abrindo caminhos para a formação de redes de relacionamentos.

A imagem de rede é emblemática para os processos de ensino e aprendizagem via meios digitais. Fonterrada (2005) aponta a substituição da busca da linearidade, simbolizada no século XIX pela estrada de ferro, pelos procedimentos não lineares do século $\mathrm{XX}$, simbolizados pela 
rede. Analisando as propostas dos principais educadores musicais, a mesma autora observa uma alteração nos modos de compreender a educação musical, passando do "procedimento em linha" dos métodos Suzuki, Kodály e Willems, para o "procedimento em rede" de John Paynter, George Self e Murray Schafer. Ainda que a Geração Net tenha surgido depois da elaboração das propostas de todos esses educadores, o pensamento dos jovens na atualidade e sua abertura para novas experiências condizem com as novas formas de ouvir que são características das idéias mais recentes na educação musical. São procedimentos abertos, não seqüenciais, "típicos dos modos de conhecer da contemporaneidade" (FONTERRADA, 2005: 175).

Tais "modos de conhecer" são refletidos também nas formas pelas quais jovens se conhecem utilizando a Internet: em websites de relacionamentos, como o Orkut (http://www.orkut.com) ou o Facebook (http://www.facebook.com), aceitam como "amigos" as conexões de seus conhecidos, ampliando suas redes de contatos exponencialmente e estabelecendo "amigos virtuais", com quem se relacionam muitas vezes exclusivamente por meios eletrônicos. Essa é uma das origens possíveis para comunidades virtuais, quando os contatos online entre os indivíduos acabam firmando relações afetivas e de confiança. Para estes indivíduos, estudar em cursos realizados a distância pode ser uma extensão da vida pessoal, já permeada pela virtualidade e habituada a comunicações mediadas por computadores. Segundo um relatório produzido pela Open eLearning Content Observatory Services (OLCOS, 2007), as ferramentas conhecidas como "softwares sociais", incluindo blogs, wikis, podcasts e sites de relacionamentos, se adotadas com finalidades educacionais, podem ter um enorme impacto de inovação, pois são ideais para processos centrados no aprendiz e para projetos colaborativos, resultando no desenvolvimento de competências essenciais para a vida na sociedade do conhecimento.

As comunidades virtuais, portanto, surgem dentro de um crescente equilíbrio entre a presença física e a virtual nos relacionamentos humanos. Na educação, segundo Demo (2002), o "direito de aprender", cada vez mais reconhecido como um direito fundamental de todos, expõe a necessidade desse equilíbrio, porque não é possível, com o ritmo frenético dos compromissos da vida cotidiana, entrar em salas de aula regularmente para escutar um professor. Moran (2002: 57) também fala da necessidade de equilíbrio entre o presencial e o virtual na educação, mas alerta que "se temos dificuldades no ensino presencial, não as resolveremos com o virtual". Para esse 
autor, a síntese dos dois tipos de comunicação, valorizando o melhor de cada um deles, é o ideal. Além de interações espaço-temporais mais livres, com as comunicações virtuais ocorrem contatos com pessoas que nos são semelhantes, mas estão fisicamente distantes. Cada dia é mais comum que os indivíduos letrados digitalmente estejam presentes no mundo virtual, abrindo contas em serviços online diversos e criando seus perfis com dados pessoais, preferências musicais, fotos e vídeos, entre outras informações que revelam traços de suas personalidades.

Enquanto a definição de Rheingold para as comunidades virtuais fala de debates em "número e sentimento suficientes para formarem teias de relações pessoais", também ocorrem interações rápidas, únicas e pontuais, entre indivíduos que não chegam a estabelecer laços pessoais. Por exemplo, é comum que comentários sobre vídeos postados na Internet, em serviços como o YouTube (http://www.youtube.com), expressem opiniões sobre o conteúdo das imagens, sem buscar um diálogo aprofundado com outros usuários do serviço. Muitas vezes o próximo comentário faz referência ao anterior, concordando ou discordando da opinião colocada. Nesse caso, é discutível se o termo "comunidades virtuais" pode ser usado, pois não há sentimento de pertencimento a um determinado grupo.

Alguns serviços de redes de relacionamentos na Internet priorizam a música como forma de integração entre os participantes. No MySpace (http://www.myspace.com), por exemplo, é comum que os usuários deixem habilitada a função que faz músicas escolhidas começarem a tocar automaticamente, sem pedir a permissão dos visitantes do website. Aliado ao aspecto visual das páginas, que podem ser modificadas e personalizadas, o elemento sonoro aparece como “cartão de visitas", mostrando a personalidade musical dos indivíduos. Muitos músicos utilizam esse serviço como meio para divulgar suas composições e produções, atualizando os blogs com notícias sobre trabalhos recentes, fotos de apresentações e gravações de suas músicas. Dessa forma, é possível ter contato com a rotina de músicos de todo o mundo, incluindo amadores desconhecidos e profissionais renomados, formando um enorme acervo de diários online.

Embora serviços online como o YouTube e o MySpace não tenham finalidades educacionais ${ }^{39}$ específicas, eles podem ser utilizados como recursos de grande valia em cursos a

\footnotetext{
39 Existem exemplos de serviços online com declarados objetivos educacionais, como o TeacherTube (http://www.teachertube.com) e o SchoolTube (http://www.schooltube.com), que têm como proposta reunir vídeos com conteúdos didáticos; e o Ning (http://www.ning.com), uma rede social visando à formação de grupos para discussões online. Na literatura sobre educação musical, há pesquisas sobre os possíveis usos do YouTube em sala de aula (WEBB, 2007 e OLIVEIRA, 2008).
} 
distância de música. Primeiramente, servem como campo de pesquisa para assuntos determinados, em atividades do tipo "encontre vídeos com demonstrações de diferentes ritmos no pandeiro"; ou "pesquise vídeos com o grupo Uakti". Ao mesmo tempo, são um repositório de exemplos para as discussões travadas em fóruns, quando os alunos fazem referência a um tema (como uma prática educacional, uma forma específica de tocar um instrumento musical ou a organização de objetos em uma sala de aula) e podem contar com vídeos para detalhar suas idéias. Cada vídeo no YouTube ou perfil no MySpace apresenta links para outras páginas, ampliando as possibilidades de se chegar a conteúdos interessantes.

No curso de percussão da UAB - UFSCar, a simples instrução "procure um vídeo mostrando um tipo de percussão que você considera interessante", colocada em um fórum na primeira semana da disciplina, gerou discussões sobre percussão corporal, utilização de diferentes objetos sonoros na música, reciclagem, valorização da cultura brasileira, entre outros assuntos que provavelmente não seriam discutidos com a mesma profundidade, caso não surgissem a partir de exemplos concretos, sugeridos pelos próprios alunos. Em casos como esse, o acompanhamento da lista de vídeos indicados, seja pelos tutores ou pelo professor responsável, é essencial para garantir que o foco das discussões não seja desviado dos objetivos da disciplina. Da mesma forma, pode-se orientar o aluno a pesquisar o endereço eletrônico de um artista na Internet, a sua página no MySpace, ou websites que reúnem biografias e informações relevantes sobre músicos ${ }^{40}$. Todo esse conteúdo online é somado aos materiais disponibilizados na Internet especificamente com objetivos educacionais: os chamados recursos educacionais abertos.

\subsection{Recursos educacionais abertos}

Desde que o Massachusetts Institute of Technology (MIT) deslanchou, no ano de 2001, o projeto intitulado OpenCourseWare (http://ocw.mit.edu), com a intenção de abrir todos os acervos de informação e conhecimento da instituição, teve início uma revolução. Em poucos anos, centenas de cursos foram disponibilizados gratuitamente na Internet, incluindo materiais de leitura, provas, slides e vídeos de aulas, entre outros conteúdos que antes só eram acessíveis aos

\footnotetext{
${ }^{40}$ Dentro do curso de percussão da UAB - UFSCar, um exemplo de website desse tipo que foi indicado aos alunos é o Drummerworld (http://www.drummerworld.com), com biografias de diversos percussionistas, incluindo fotos, vídeos de suas performances e links para outras referências.
} 
alunos daquela universidade. Entre esses cursos, várias disciplinas de música estavam presentes, possibilitando que professores e estudantes de todas as partes do mundo vejam como funcionam os cursos do MIT. Rapidamente, outras instituições anunciaram iniciativas similares, a exemplo da Open University, que, no projeto OpenLearn (http://openlearn.open.ac.uk), também oferece materiais de suas disciplinas de música.

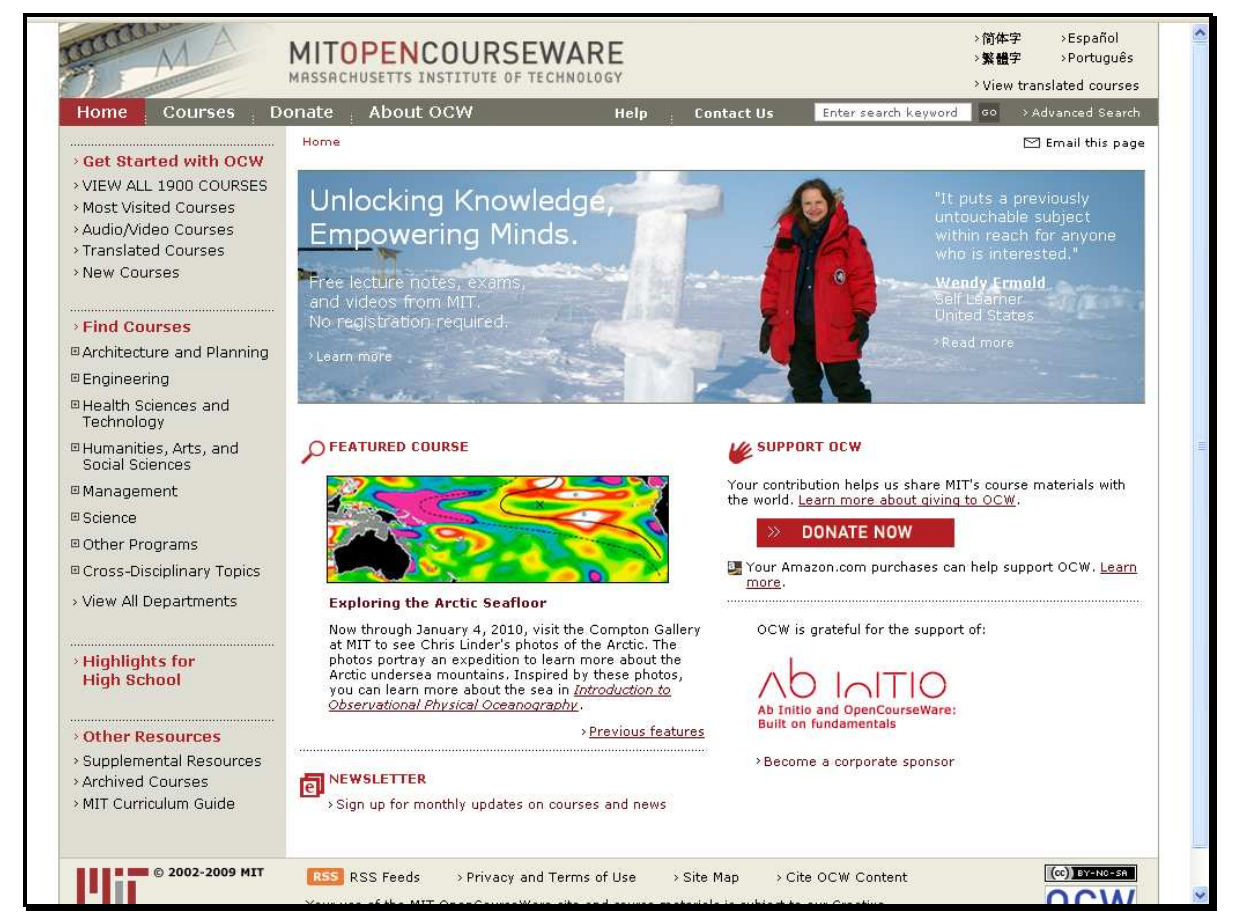

Figura 2: website do OpenCourseWare, projeto do MIT

Tais acontecimentos são marcos importantes no que se convencionou denominar um "movimento" (OECD, 2007): os recursos educacionais abertos (open educational resources OERs). Este termo foi criado e divulgado pela United Nations Educational, Scientific and Cultural Organization (UNESCO) em 2002, como parte do relatório final de um fórum sobre educação superior nos países em desenvolvimento (OLCOS, 2007). Como diz Litto (2008c), para uma parte muito ampla da população mundial, os recursos educacionais abertos "representam uma significativa opção para estender e democratizar o acesso ao conhecimento, à racionalização de despesas com livros-texto e outros materiais para aprendizagem em todos os níveis" (LiTTO, 2008c: 304). Para os professores, tanto os atuantes como aqueles ainda em formação, há ricas 
oportunidades de observar como são ministrados os cursos de diversas instituições, abrindo alternativas para o uso de idéias, processos e conteúdos ${ }^{41}$. Por outro lado, os recursos abertos são úteis para alunos e aprendizes em geral.

Alguns OERs podem ser "nacos" de conhecimento que contribuem para a compreensão de um assunto complexo, e por isso são tão bons para aqueles que querem ou precisam aprender como autodidatas, adquirindo o conhecimento desejado espontaneamente e com um alto grau de motivação, quanto para aqueles que os aproveitam dentro da estrutura de um curso (LiTTO, 2006: 63).

O curso de percussão da UAB - UFSCar utilizou vários recursos abertos da Internet, sempre com a preocupação de buscar fontes confiáveis e fidedignas. Tal questão foi discutida por Litto (2008c: 307), que destaca a existência de um "pedigree" dos OERs, ou seja, há uma maior aceitação de materiais vindos de instituições ou grupos com grande prestígio no cenário acadêmico. Várias universidades que são conhecidas como referências mundiais de boa educação, como Stanford, Oxford e Yale, participam do projeto iTunes University, organizado pela empresa Apple e acessível através do software iTunes. Nesse projeto, são disponibilizadas gravações de áudio e vídeos de aulas, palestras e seminários que acontecem em seus campi. A abertura das portas dessas instituições para o mundo modifica a noção de que "o que é de graça não deve ser muito bom".

Os conteúdos abertos da Internet beneficiam professores e alunos com informações do "mundo real", ao invés de exemplos antigos e simplificados, que muitas vezes são estudados sem dados atualizados (OLCOS, 2007). Na atividade da UAB - UFSCar que foi mencionada anteriormente, quando vídeos de percussão foram indicados em um fórum, vários projetos e conteúdos recentes entraram em discussão ${ }^{42}$. As trocas de informação sobre essas indicações mostraram-se bastante produtivas, permitindo aos alunos entrar em contato com diversos modelos para atividades educacionais. Alguns dos participantes que já trabalham como professores de música relataram a utilização de idéias demonstradas nos vídeos em suas aulas, incentivando seus colegas a experimentar propostas similares.

\footnotetext{
${ }^{41} \mathrm{Na}$ área da música, um exemplo específico é o website BerkleeShares (http://www.berkleeshares.com), da Berklee School of Music, onde são disponibilizados planos de aulas, organizados por assunto.

${ }^{42}$ Entre os vídeos estudados, podemos destacar trabalhos dos grupos Barbatuques, Palavra Cantada, Brincante, Uakti, Meninos do Morumbi, Patubatê e Stomp, além de algumas produções dos próprios alunos.
} 
Além dos projetos de grande porte, como o OpenCourseWare e o OpenLearn, existem vários outros, menores e pontuais, mas com grandes potenciais para usos na educação musical a distância. Um exemplo que contribui para lidar com questões multiculturais é o Virtual Instruments Museum (http://learningobjects.wesleyan.edu/vim), um museu virtual produzido pela Wesleyan University. Nesse website, uma vasta gama de instrumentos é detalhada, apresentando detalhes em fotos, descrições textuais, imagens que podem ser colocadas em rotação, e vídeos com especialistas demonstrando as possibilidades sonoras de cada peça. $\mathrm{O}$ uso desse projeto no curso de percussão da UAB - UFSCar ocorreu em uma atividade denominada "glossário", em que cada aluno deveria pesquisar sobre um instrumento diferente, contribuindo para montar uma espécie de "dicionário da percussão". O desejo dos alunos em trazer instrumentos de características peculiares e inusitadas foi revelado, deixando evidente que os websites indicados na atividade, incluindo o Virtual Instruments Museum, foram extensamente explorados. Em muitas das contribuições, diversas fontes online foram consultadas, comprovando que os trabalhos de pesquisa eram consistentes, articulando várias informações complementares e evitando a simplicidade de processos do tipo "copiar e colar".

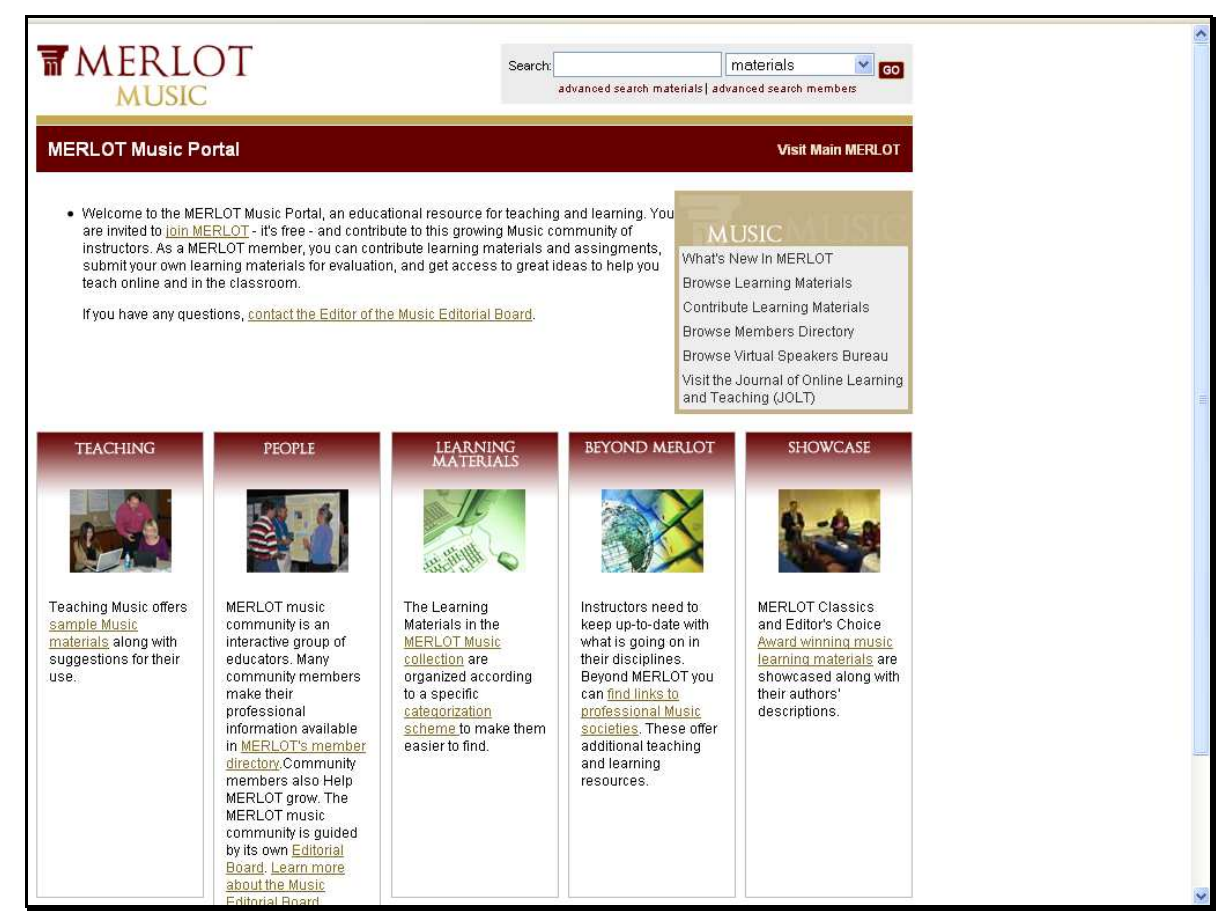

Figura 3: website do repositórios de objetos de aprendizagem Merlot 
Outros modelos de recursos educacionais abertos são os repositórios de objetos de aprendizagem, websites que reúnem simulações, vídeos e animações, entre outros conteúdos reutilizáveis para auxiliar aprendizagens. Alguns desses repositórios, como o Merlot (Multimedia Educational Resource for Learning and Online Teaching), apresentam portais dedicados à música (http://music.merlot.org), com objetos que são enviados ou indicados por professores voluntários. Por meio desse portal, os alunos da UAB - UFSCar tiveram acesso a documentos da P.A.S. (Percussive Arts Society), uma organização de percussionistas surgida nos Estados Unidos em 1961, relacionando rudimentos para a prática com baquetas, juntamente com gravações de como esses exercícios devem soar. Nesse exemplo, fica claro um dos fatores apontados por Litto (2008c) para impulsionar o desenvolvimento de OERs: trata-se de uma estratégia para contornar o alto custo de livros e demais materiais utilizados em escolas e universidades.

No entanto, conteúdos que ficam disponíveis para o planeta inteiro trazem a tona dois desafios que são comumente mencionados por pesquisadores de EAD. Primeiramente, pode haver uma barreira lingüística, já que, como já foi colocado anteriormente, o inglês é o idioma predominante na Internet; e, em segundo lugar, podem ocorrer dificuldades de utilização sem que haja uma contextualização dos recursos. Segundo Lane (2008), a partir das suas conclusões com experiências no projeto OpenLearn, o suporte de colegas e profissionais é a chave para a reutilização de materiais abertos. Havendo o auxílio apropriado, este autor destaca o papel que os OERs podem ter no processo educacional de comunidades excluídas, desde que tenham acesso a computadores e à conexão com a Internet. Entre as possíveis razões para a exclusão educacional, Lane cita as limitações impostas por normas culturais e sociais, que cultivam a crença de que certos indivíduos não são capazes ou inteligentes o suficiente para estudar. Tal observação denota o grande potencial dos OERs em um país como o Brasil, onde notadamente há problemas no oferecimento de escolaridade para a população.

A formação de educadores musicais, ao promover o contato e o trabalho com os recursos educacionais abertos, familiariza o futuro professor com o conceito e a utilidade desses materiais, abrindo perspectivas para o seu uso em atividades e na programação de projetos. Da mesma forma, o aprendizado com os vários softwares que são encontrados gratuitamente na Internet, como foi visto no capítulo 3 , cria possibilidades que dependem exclusivamente do acesso à Internet e de orientações adequadas. Os OERs são ferramentas que aproximam os universos da 
educação formal e informal, contribuindo também para lidar com uma crescente demanda por educação continuada (OECD, 2007).

A exaltação de alternativas surgidas com o movimento de recursos educacionais abertos pode soar exageradamente otimista, se considerados os empecilhos de larga escala encontrados nos países em desenvolvimento, a começar com a necessidade de acesso às tecnologias. Mas, com a constatação de bons resultados em projetos de inclusão digital realizados no Brasil, justifica-se a credibilidade dada aos OERs e um empenho por sua aplicação na educação a distância. Um exemplo bem sucedido nesse sentido é o projeto Tonomundo (http://www.tonomundo.com.br), uma iniciativa da Escola do Futuro da USP em parceria com o Instituto Oi Futuro, que inicialmente recebeu o nome de projeto Telemar Educação (BANNAN e GoHN, 2004). Atuando em 16 estados brasileiros, esse programa teve um curso de construção de instrumentos musicais como parte da capacitação de professores da rede pública de ensino, constituindo uma etapa de pesquisa nessa tese de doutorado (GoHN, 2007).

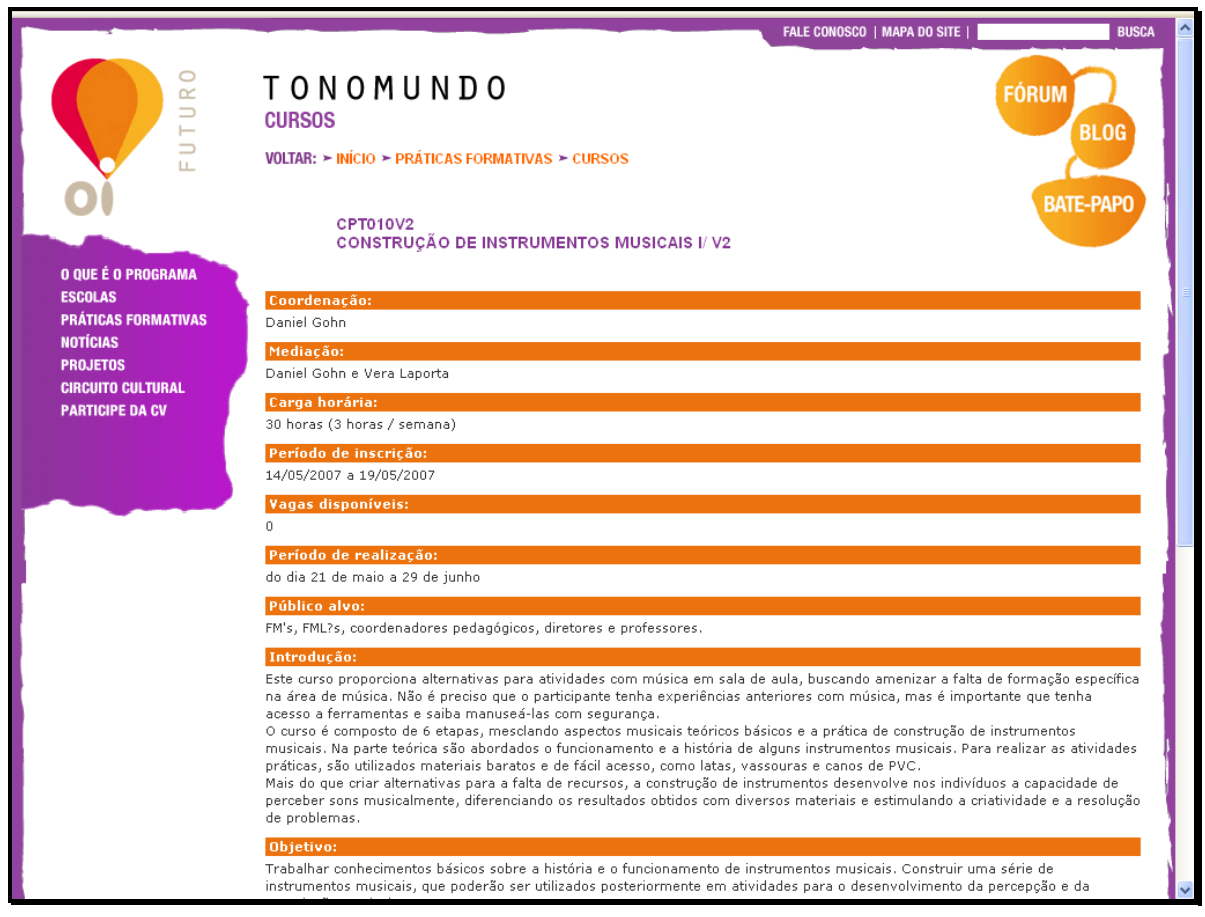

Figura 4: curso de construção de instrumentos musicais no Projeto Tonomundo 
Enquanto alguns esforços são feitos na tradução de conteúdos do inglês para a língua portuguesa $^{43}$, estudos indicam a importância do desenvolvimento local de recursos abertos na Ásia, na África e na América do Sul, tendo uma preocupação com a relevância cultural e educacional, e com a acessibilidade e a viabilidade técnica (OECD, 2007). Dessa forma, países nesses continentes deixarão de ser meros consumidores para tornarem-se produtores. $\mathrm{O}$ curso do projeto Tonomundo mencionado acima, usando a construção de instrumentos musicais como meio de sensibilização à música, seria amplamente beneficiado se contasse com OERs de instrumentos africanos, dando chance para a diversidade cultural e para projetos em que brasileiros ensinam africanos a construir seus instrumentos e vice-versa.

Há diversas possibilidades para o uso da Internet e seus recursos abertos em processos de educação musical a distância. Em cursos formais, como foi visto neste capítulo, o suporte de conhecimento específico aos alunos é essencial. Tal suporte está diretamente relacionado com os diferentes tipos de conhecimento musical, como será observado a seguir.

\footnotetext{
43 A rede Universia oferece diversos cursos do projeto OpenCourseWare, do MIT, traduzidos para o português (http://www.universia.com.br/mit).
} 


\section{Para discutir a educação musical a distância}

\subsection{Tipos de conhecimento}

O conhecimento musical tem muitas camadas, com diversas tranças que freqüentemente são costuradas na nossa experiência real, mas que são separáveis para finalidades de compreensão e análises detalhadas (SWANWICK, 1994: 15).

O suporte para alunos em cursos de música realizados a distância impõe grandes desafios, pois diversos conteúdos demandam habilidades específicas para que seja possível prestar auxílio aos estudos. Por exemplo, como poderia um tutor sem conhecimento musical servir como referência para estudantes em um curso de harmonia? Ou como um tutor sem domínio técnico de um instrumento poderia demonstrar os movimentos apropriados para extrair suas possíveis sonoridades? Estas perguntas tornam evidente a necessidade de capacidades do tutor dentro da área em que está atuando, tanto para servir de exemplo em atividades a realizar como para compreender dúvidas e dificuldades encontradas pelos alunos.

Dependendo da situação em questão, pode existir a possibilidade de pedir auxílio externo, seja ao professor responsável pela criação do curso ou a outros especialistas, que poderão indicar referências ou responder perguntas apenas com o uso do telefone ou via e-mail. Se os estudos permanecem no campo das idéias, é menor a necessidade de haver contatos imagéticos, pois não há procedimentos a visualizar. Mas, quando o tema associa idéias com exercícios práticos, muitas vezes uma explicação só é possível com a demonstração de movimentos e processos, tornando um pedido de ajuda mais complicado.

Um exemplo do primeiro caso seria um curso sobre a história do jazz em que surge uma dúvida por parte de um aluno: "qual foi a relação entre o desenvolvimento do jazz na cidade de Chicago e a entrada dos Estados Unidos na Primeira Guerra Mundial?” Caso o tutor designado para o curso não saiba responder, uma breve consulta a um professor especialista poderia gerar a seguinte resposta: "leia este trecho do livro de Joaquim Berendt, na página 26":

Nova Orleans se transformou na época num porto de guerra. O Ministro da Marinha via no excitante bairro de diversões da cidade um verdadeiro perigo para a moral de sua tropa, razão pela qual "Storyville" foi fechada por decreto oficial. Com isso, centenas de músicos ficaram desempregados e, em busca de 
trabalho, se transferiram para outras cidades - sobretudo para Chicago. (...) $\mathrm{O}$ fato curioso a se registrar aqui é que o primeiro estilo do jazz, o New Orleans, viveu seus primeiros grandes momentos não na cidade que lhe deu o nome, mas na Chicago dos anos 20 (BERENDT, 2007: 26).

Este tipo de questionamento é resolvível por meio de comunicações na forma textual. Dezenas de outras referências poderiam ser dadas, entre livros publicados e websites, tendo a palavra escrita como forma de resposta à pergunta. Cursos de música lidam com muitas dúvidas dessa natureza, podendo ser solucionadas por tutores ou professores a distância. Provavelmente, o mesmo livro de Joaquim Berendt seria utilizado também em uma aula presencial, talvez com algumas observações realizadas oralmente pelo professor como complementação.

No entanto, há uma situação diferente ao se imaginar um curso de percussão em que um aluno apresenta como indagação: "estou praticando o primeiro exercício de baquetas, mas quando coloco o metrônomo no andamento indicado, tenho dificuldades e sinto muita tensão em minhas mãos. Devo insistir?" Se a pergunta for recebida por um tutor e este recorrer ao professor responsável, uma conversa ao telefone provavelmente não irá resolver o problema. Este outro tipo de questionamento exige comunicações mais complexas entre mestre e aprendiz, pois estão envolvidas muitas variáveis. A resposta do professor poderia ser: "preciso observar o aluno praticando para saber se realmente há uma tensão muscular excessiva durante o exercício, ou mesmo o princípio de um problema mais sério, e caso isso seja constatado, ele não deverá insistir, pois poderá se lesionar".

A melhor forma de lidar com esta situação a distância é havendo contato visual entre o aluno e o professor. Será que a dor é resultante de um posicionamento corporal inadequado para o exercício? Será que o aluno apresenta características especiais que o impede de praticar nas mesmas condições de seus colegas? Para chegar a conclusões seguras, é preciso observar o estudante durante a sua prática, o que dificilmente pode ser verbalizado. Obviamente, explicar uma ação por meio de palavras não é o mesmo que realizar essa ação, logo, sem visualizar o momento em que a tensão ocorre nas mãos do aprendiz, dificilmente o professor poderá identificar a origem do problema. Em longo prazo, a consequiência para o aluno poderá ser uma tendinite, o que irá forçá-lo a interromper seus estudos por completo. Em aulas realizadas a distância, mesmo com contato visual, após constatar alguma questão dessa natureza, não se pode contar com um recurso comum nas aulas presenciais: o contato físico. 
Nas explanações que lidam com movimentos corporais, como ocorre no aprendizado de instrumentos musicais, além de demonstrar uma postura correta, os professores podem tocar o aluno e colocá-lo nessa postura. No exemplo mencionado acima, talvez o professor identificasse uma tensão excessiva nos dedos do aluno e pudesse ajudá-lo modificando a "fôrma" de suas mãos, pegando cada um dos dedos e reposicionando-os na maneira de segurar as baquetas. Tal auxílio também é possível sem o contato físico, já que o professor pode demonstrar posturas e movimentos mais adequados e fazer as correções verbalmente, com frases como: "deixe o dedo indicador mais curvado e procure relaxar o dedo anular". De qualquer forma, para que o feedback seja adequado, é melhor que o elemento visual esteja presente, mesmo que por meios tecnológicos.

David Elliot (1995: 53) explica essa dificuldade em tratar verbalmente da questão ao dizer que "fazer música é essencialmente uma questão de conhecimento procedimental". O autor fala das formas multidimensionais dos conhecimentos envolvidos no que se chama de musicalidade, mas ressalta que a "musicalidade é demonstrada em ações, não em palavras". As palavras podem apenas descrever o que acontece em uma música, mas não explicam o que realmente acontece quando músicos tocam e improvisam.

Enquanto o desenvolvimento do pensamento verbal depende profundamente de conceitos verbais, o lado prático da "reflexão-sobre-a-ação" "44 depende muito de conceitos práticos não-verbais. Assim como conceitos verbais surgem, são desenvolvidos e utilizados na área da linguagem, conceitos práticos surgem, são desenvolvidos e utilizados na ação (ELLIOT, 1995: 53).

A idéia de "conceitos práticos" colocada por Elliot considera como "conceito" uma unidade cognitiva que pode ser manifestada em palavras, imagens ou ações práticas. Para desenvolver os conceitos práticos, um indivíduo precisa desenvolver competências nos conhecimentos procedimentais da música e ter contato em primeira mão com as circunstâncias em que esses conhecimentos são usados. Sem fazer música, é possível aprender alguma coisa e ter prazer lendo livros sobre música e ouvindo gravações, mas não haverá a experiência direta e concreta. Da mesma maneira, é possível assistir outras pessoas dirigindo carros e ler um manual com instruções, mas somente com uma direção nas mãos é que se sabe exatamente como é conduzir um veículo motorizado.

\footnotetext{
${ }^{44}$ Original em inglês: practical thinking-in-action.
} 
Demonstrações com um instrumento musical são conceitos práticos e servem para ensinar aos aprendizes da mesma forma que conceitos verbais servem para ensinar pensamentos verbais. As ações de um músico não são inatas, são conseqüências de uma elaboração de movimentos que é obtida com a reconstrução de determinados padrões. Ao tocar um exercício para o aluno, um professor está contribuindo para a compreensão de conceitos práticos, que serão somados a conceitos verbalizados para desenvolver a sua musicalidade. Elliot denomina os conhecimentos práticos como "procedimentais" e os conceitos verbalizados como "conhecimento musical formal".

O conhecimento musical formal ${ }^{45}$ inclui fatos, conceitos, descrições e teorias que podem ser verbalizados, ou seja, todo tipo de informação sobre música que pode ser colocada em textos. No exemplo do aluno com dúvidas sobre a história do jazz, dado no início desse capítulo, a resposta envolve um conhecimento formal que facilmente pode ser verbalizado. Esse tipo de conhecimento, seja sobre história da música, teoria musical, práticas de performance instrumental e vocal ou outros assuntos relacionados à música, pode "influenciar, guiar, moldar e refinar a 'reflexão-sobre-a-ação' musical dos alunos”' (ELLIOT, 1995: 61).

Keith Swanwick adverte que conhecimento sobre coisas pode ser obtido de formas não musicais, simplesmente lendo sobre o assunto, mas sem nenhuma experiência direta (que ocorre tocando ou ouvindo uma peça musical, por exemplo). Nesse caso, embora o aprendizado possa ter algum valor histórico, é musicalmente inerte, um "conhecimento de segunda-mão" (SWANWICK, 1994: 16). O autor comenta que trabalhar com esse conhecimento é sedutor, pois é relativamente fácil de se levar para a sala de aula e pode ser acessado a custos razoavelmente baixos, mas que tal facilidade, desligada de um contexto musical genuíno, deve ser resistida.

O segundo exemplo dado anteriormente, do aluno de percussão reclamando de dores musculares, envolve um conhecimento procedimental que dificilmente pode ser colocado em palavras. É o que Swanwick (1994: 16) denomina “conhecimento de primeira mão"46. Para que o aluno possa aumentar a marcação do metrônomo sem enfrentar problemas de tensões excessivas nas mãos, é preciso refinar seus conceitos práticos. Mas, se por um lado um exercício com

\footnotetext{
${ }^{45}$ Para Elliot (1995: 60), outro termo equivalente seria conhecimento proposicional; Swanwick (1994: 15) menciona as palavras proposicional, informacional, factual, "saber que".

46 Swanwick (1994: 17) cita três "conhecimentos de primeira mão", na seguinte ordem de importância: discriminações auditivas (habilidade de identificar, classificar e utilizar os materiais que formam a base da música); controle de instrumentos (habilidade de coordenar músculos e articular os controles de um determinado instrumento de forma adequada); e proficiência com notação musical (habilidade de decifrar e escrever partituras).
} 
baquetas é essencialmente procedimental, por outro, vários tipos de conhecimento formal podem auxiliar a resolver a questão. Por exemplo, a leitura de estudos sobre alongamentos musculares específicos para performers musicais (como o trabalho de RAY e ANDREOLA, 2005) pode prevenir lesões, e saber por meio da história da música que muitos instrumentistas tiveram tendinites causadas pela repetição contínua de movimentos traz consciência sobre o problema. Para Swanwick (1994: 17), embora a "experiência com" não possa ser substituída por "falar sobre”, análises e conversações podem iluminar a aprofundar a compreensão musical.

Para chegar aos princípios necessários a uma determinada ação, o conhecimento formal pode ser convertido em conhecimento procedimental. Alguns estudantes aprendem melhor de forma não-verbal, apenas ouvindo e observando modelos de conceitos práticos; outros têm maior facilidade com o auxílio de conhecimentos formais. Tais diferenças, quando reconhecidas e valorizadas, proporcionam uma visão multidimensional da inteligência humana e se tornam aspectos importantes em processos de ensino e aprendizagem.

Alguns instrumentistas e compositores falam e escrevem sobre música e sobre o fazer musical, outros se concentram nos atos de tocar e compor. Portanto, embora o conhecimento formal da música seja necessário para se tornar musicólogo, professor ou crítico de música, não é um elemento necessário para se alcançar uma musicalidade elevada. É possível desenvolver a musicalidade sem ler livros sobre música ou entrar em contato com discursos verbais sobre música. Por esta razão, "a aquisição de conhecimento musical formal é um objetivo adequado, mas secundário da educação musical" (ELLIOT, 1995: 62).

\subsection{Aprendizagem informal e EAD}

Segundo David Elliot, além dos conhecimentos formais e procedimentais, a musicalidade também tem três outros tipos de conhecimento: informal, impressionístico e supervisional ${ }^{47}$. O conhecimento informal é aquele que não está disponível em textos ou livros, e pode ser referido como "experiência", sendo em grande parte resultado do esforço do aprendiz para identificar e solucionar problemas em contextos musicais. O conhecimento impressionístico está relacionado com a intuição e com os sentimentos, quando se decide que uma linha de ação é melhor do que outras. Por último, o conhecimento supervisional possibilita a um indivíduo dirigir o avanço de

\footnotetext{
${ }^{47}$ Original em inglês: informal, impressionistic e supervisory.
} 
sua musicalidade ao longo do tempo, ajudando-o a monitorar e a coordenar as outras formas de conhecimento musical. Enquanto os termos impressionístico e supervisional não surgem com freqüência em pesquisas sobre educação musical, em anos recentes diversos estudos tiveram como objeto de análise os meios para o desenvolvimento de conhecimento informal (FOLKESTAD, 2006).

Santiago (2006), por exemplo, observou duas abordagens distintas em estudos instrumentais de música: a prática deliberada ${ }^{48}$ e a prática informal. Enquanto o ensino formal de instrumentos tende a valorizar habilidades técnicas e o desenvolvimento de repertório, na lista de práticas informais, usualmente empregadas por músicos populares e músicos de jazz, a autora cita a improvisação, a composição, o arranjo e o tocar de ouvido. Nessas atividades, o estudante geralmente está em contato com seu instrumento e aprende a partir do fazer, tendo experiências que são repetidas e aprimoradas com o tempo.

O conhecimento informal surge com aprendizagens que não estão listadas e planejadas nos currículos de instituições educacionais. Investigando principalmente o campo da música popular, Green (2008: 120) identificou dois tipos de aprendizagem informal: a aprendizagem em grupo e a aprendizagem direcionada por colegas. No primeiro caso, estão aprendizagens que ocorrem de forma inconsciente ou até mesmo acidental, simplesmente com a participação em atividades coletivas. Durante o fazer musical, a aprendizagem acontece por meio de observação, escuta e imitação; antes e depois do fazer musical, há questões de organização, trocas de idéias, conhecimentos e opiniões sobre música, inversões de função, sugestões de diferentes acordes, ritmos e melodias, entre outros casos. Nas palavras de Jorgensen (2003: 65), a aprendizagem informal nos remete à "antiga idéia de soprar conhecimento e vitalidade para dentro de outra pessoa".

Quando a aprendizagem é direcionada por colegas, também ocorre por meio de observação, escuta e imitação, mas há uma intencionalidade no ato de ensinar, por parte de um ou mais colegas, para que outros possam aprender. Em ambos os casos, com ou sem intenção no processo de ensino e aprendizagem, a convivência com o outro é que irá gerar uma autonomia futura, quando o acúmulo de experiências permitirá que um indivíduo passe do papel de mero observador para também ser objeto da observação. Fica evidenciado, como diz Jorgensen (2003:

\footnotetext{
${ }^{48}$ A autora destaca que o termo "prática deliberada" tem sido utilizado por diversos pesquisadores e corresponde ao uso que também é dado para "prática formal", "prática efetiva" e "prática estruturada" (SANTIAGO, 2006: 53).
} 
37), que "paradoxalmente, a única forma de conseguir liberdade individual é através do trabalho com outros".

Este é um processo individual de reflexão e ação, em que cada situação é avaliada criticamente e mudanças são realizadas considerando-se o contato com outros. Tais tipos de aprendizagens invariavelmente também acontecem nas instituições formais de ensino, pois certamente os alunos não têm os currículos de seus programas como foco único e exclusivo de suas atenções. Conversas nos corredores e ensaios de conjuntos formados e dirigidos pelos próprios alunos, antes e depois das aulas, são exemplos de oportunidades para que o convívio entre pares sirva como meio de aprendizado. De maneira consciente ou não, os colegas de um determinado indivíduo farão diferença na sua educação, sendo que, se seus estudos fossem realizados em anos anteriores ou posteriores, outros colegas poderiam produzir impactos diferentes.

Logicamente, em um curso de música realizado a distância, a separação física entre os alunos, em grande parte ou na totalidade do período de estudos, modifica as condições em que suas conversas e ensaios ocorrem. No curso de Licenciatura em Educação Musical da UAB UFSCar, há encontros presenciais regulares entre alunos e tutores ${ }^{49}$, quando acontecem interações similares àquelas dos cursos inteiramente presenciais. No entanto, o convívio social e as trocas de idéias e opiniões na sala de aula geralmente são breves, já que nos demais dias da semana não há encontros programados. Até a próxima reunião, alunos poderão retornar a diferentes cidades de origem e retomar rotinas de trabalho com horários diversos. Assim, os contatos que começam naqueles momentos prosseguem com interações virtuais, na forma de textos escritos, em fóruns, e-mails e bate-papos; ou com outras ferramentas de comunicação, como conversas via VoIP, utilizando o programa Skype.

Da situação colocada no parágrafo anterior, conclui-se primeiramente que o professor interessado em valorizar e promover a aprendizagem informal, ao preparar uma disciplina para o curso, deve aproveitar os momentos em que alunos estão juntos não somente para que resolvam dúvidas com seus tutores, mas também para que compartilhem experiências procedimentais, que poderão ser comentadas verbalmente no decorrer da semana. Por exemplo, na disciplina Percussão, atividades conjuntas podem resultar em aprendizagens em grupo, com observações,

\footnotetext{
${ }^{49}$ As datas dos encontros presenciais são estabelecidas no início do semestre, ocorrendo semanalmente. Como será detalhado mais tarde, nesses momentos os alunos têm o auxílio dos tutores presenciais. Também existem os tutores virtuais, que ficam disponíveis a distância, por meio do ambiente virtual de aprendizagem.
} 
escutas e imitações entre alunos; e aprendizagens direcionadas por colegas, quando um aluno mais experiente auxilia outro em suas práticas e exercícios.

Por outro lado, se os períodos de reunião presencial não são extensos, os diálogos virtuais são atividades que constam nos currículos e contam nos processos de avaliação de todas as disciplinas do curso de Licenciatura em Educação Musical. Com isso, chega-se a uma segunda conclusão: a trocas de idéias, conhecimentos e opiniões sobre música, que nos cursos presenciais usualmente ocorre nos corredores, longe do alcance do professor, em cursos a distância acontecem no ambiente virtual, ficando registradas para futuras análises e reflexões. O aluno que não participar dessas conversas terá notas menores, pois não é possível ficar calado no fundo da sala, apenas fingindo tomar parte de uma discussão. A presença de cada indivíduo deve se fazer perceber de maneira ativa, expondo pontos de vista, elaborando argumentos e desenvolvendo raciocínios.

Portanto, embora a participação no ambiente virtual seja uma tarefa formalizada pelo currículo do curso, diversas aprendizagens informais podem resultar das comunicações entre alunos. E, ao invés de perderem-se no espaço e no tempo, tais comunicações podem ser retomadas posteriormente, por professores, tutores ou pelos próprios alunos, ficando abertas para críticas e comentários de todos. Certamente, também poderão ocorrer conversas virtuais fora do ambiente do curso, por meio de e-mails e bate-papos, que mais se aproximariam da situação encontrada nos corredores de instituições formais. Ao expor suas colocações para o grupo todo, em determinados momentos sabendo que estão sendo avaliados, os alunos poderão não postar suas opiniões verdadeiras, seja para amenizar divergências com outros, para não revelar seus gostos pessoais, ou por quaisquer outras motivações. Mas, com as várias alternativas tecnológicas disponíveis, estes alunos podem entrar em contato com apenas um (ou mais) de seus pares e tecer comentários que não seriam "politicamente corretos", caso divulgados para todos. Por exemplo, um aluno poderia não dizer que não gostou da composição de um determinado colega, por receio de gerar antipatia e mal estar. Em um e-mail, trocado com outro colega, essa opinião poderia surgir e dar vazão a uma discussão sobre o estilo de vários artistas, produzindo um resultado positivo para ambos os interlocutores.

Segundo Lucy Green (2008: 3), até um passado recente, a maioria dos educadores musicais não tinha reconhecido e demonstrado interesse no entusiasmo e na dedicação que 
muitos alunos apresentam em suas aprendizagens informais, principalmente ao observar e imitar seus ídolos na música popular. Na análise dessa autora, mesmo que os conteúdos curriculares tenham sido modificados nos últimos quarenta anos, nas instituições formais não há espaço para métodos de ensino alternativos, diferentes dos formatos tradicionais, que aproveitem os processos que foram tornados usuais em vários estilos populares de música, como no jazz ou na world music. Tanto na educação a distância como na presencial há grandes oportunidades para trazer a aprendizagem informal para o âmbito formal. No entanto, existe uma diferença importante: na modalidade a distância, com a maior flexibilidade de horários para os estudos, os alunos podem continuar com rotinas de trabalho e manter atividades que em muitos casos não seriam compatíveis com aulas presenciais. Quando são acolhidas por colegas, tutores e professores, as diferentes realidades decorrentes desses cotidianos servem como fontes para discussão. Sendo assim, um amplo espectro de experiências pode ser compartilhado por meios virtuais, se houver estímulo para tanto nas atividades do curso. Podem ser postados ensaios dos alunos com suas bandas locais, aulas lecionadas no conservatório da cidade, concertos das orquestras de que fazem parte, entre outras situações que usualmente não são observadas nos currículos de instituições formais.

Como será detalhado mais adiante, no curso de Licenciatura em Educação Musical da UAB - UFSCar, uma das formas de avaliação da disciplina Percussão é o envio de vídeos, produzidos pelos alunos para demonstrar seu desenvolvimento com os exercícios propostos. Em cursos a distância, quando vídeos são acessíveis para toda a turma, possibilitam a observação dos momentos de prática de cada um, demonstrando as soluções encontradas para lidar com problemas comuns, dando entrada ao local em que se realizam os estudos. Esta situação é uma maneira de trazer para o âmbito formal a aprendizagem que ocorre quando os aprendizes visitam presencialmente a casa de seus colegas e aprendem com eles. Ou seja, há uma formalização de momentos que antes só aconteciam informalmente. Em complementação a isso, os vídeos que são gravados pelo professor mostram práticas já lapidadas que devem ser estudadas para posterior avaliação. Assistir aos resultados de outros alunos, ainda em processo de desenvolvimento, apresenta alternativas aos vídeos com o "produto pronto", possivelmente criando identificações que incentivam um indivíduo a alcançar o patamar em que outros se encontram.

As pesquisas de Green (2008: 8) comprovam que o tempo dedicado aos estudos musicais 
em aprendizagens informais varia muito, freqüentemente ficando condicionado ao humor do aprendiz, seus compromissos do cotidiano, ou fatores externos como uma nova banda ou uma nova composição. Na educação formal, é esperado que os alunos mantenham uma intensa disciplina de estudos, sendo que na EAD essa expectativa é ainda mais rigorosa. Como não há encontros diários entre o aprendiz e seus professores e colegas, a responsabilidade para manter horários e dedicar a atenção aos assuntos importantes é transferida aos alunos. Há muitos desvios possíveis nesse processo, especialmente com as novas tecnologias de informação e comunicação.

Estando o aluno na frente de um computador conectado à Internet, para receber materiais do curso, ler seus textos e contribuir com as discussões de seu grupo, a possibilidade de visitar diversos websites, relacionados ou não ao tema de estudo, representa uma ameaça a sua concentração. A facilidade de comunicação com amigos ou colegas de curso, via programas de bate-papo ou com áudio e vídeo, é outro fator de distração constante. Assim como todos aqueles estudando online, o aluno de EAD enfrenta desafios para o gerenciamento do seu tempo, tendo que lidar com a profusão de informações que cerca todos os indivíduos vivendo na atualidade.

Mas, para os estudantes pertencentes à Geração Net, exercer diversas tarefas simultaneamente não é um problema. Muito pelo contrário, é um fator que alimenta o interesse pelos cursos (OBLINGER e OBLINGER, 2005). As gerações que cresceram em meio aos computadores passam grande parte de seus dias jogando games online, trocando e baixando arquivos de músicas, e formando e mantendo redes sociais virtuais. Muitas dessas redes desenvolvem-se para construir comunidades e criam novas oportunidades para aprendizagens informais, em fóruns de atividades colaborativas (SALAVUO, 2006).

Claramente, a vida pessoal dos indivíduos cada vez mais fica conectada ao computador e à Internet. Estudo, trabalho, amizades, relações profissionais e projetos colaborativos se misturam nos vários softwares que são utilizados simultaneamente. Logo, como diz Folkestad (2006: 135), "formal - informal não deveria ser considerado como uma dicotomia, mas sim como dois extremos de um contínuo; na maioria das situações de aprendizagem, esses dois aspectos estão em vários graus presentes e interagindo". Os estudos formais, fechados dentro dos muros das escolas, se abrem na medida em que a Internet é utilizada como ferramenta de pesquisa e, conseqüentemente, como meio de interagir com o mundo.

Ainda segundo Folkestad (2006: 142), a visão de que a aprendizagem formal acontece 
somente em instituições e a aprendizagem informal acontece apenas fora da escola é simplista e falsa, e assim sendo a distinção entre formal e informal não pode considerar exclusivamente o elemento físico, ou seja, o local onde ocorre a aprendizagem. O que definiria essa distinção seria a forma de aprender, se há uma seqüência curricular pré-definida e se há uma relação de professor e aluno ou não. Nesse aspecto, Folkestad (2006) difere de Green (2008), pois considera que, sempre que alguém assumir um papel de professor, mesmo fora de um contexto formal, como um dos músicos em um conjunto musical, a aprendizagem resultante de sua ação deve ser considerada formal. Nesse pensamento, não existe uma "aprendizagem informal direcionada por colegas”, porque qualquer intencionalidade de ensino caracteriza uma situação formal.

Entretanto, estes dois autores concordam ao validar a presença de maneiras informais de aprender dentro de instituições. Folkestad afirma que professores podem criar situações para o desenvolvimento de aprendizagens informais, usando atividades em que a intenção não é aprender sobre música, mas tocar, ouvir, dançar e viver com a música. Nesse sentido, a proposta é a mesma de Swanwick (1994): priorizar os "conhecimentos de primeira mão", procedimentais, sobre os "conhecimentos de segunda mão", proposicionais. No contexto de um curso realizado a distância, os diferentes tipos de conhecimento musical trazem desafios específicos, dependendo da disciplina em questão.

\section{3 Áreas da música}

Uma reflexão sobre educação musical a distância deve considerar qual é o objeto do processo educacional, pois nele encontra-se a origem dos desafios para a apresentação de conteúdos e para o suporte aos alunos. Cada área de estudo da música exige atenções diferentes para conceitos procedimentais e conhecimentos formais, muitas vezes demandando a existência de recursos tecnológicos específicos para viabilizar as interações entre aluno e conteúdo, aluno e professor, e aluno e seus colegas.

Por exemplo, uma consulta textual informa que Igor Stravinsky compôs A Sagração da Primavera na primeira metade do século XX, sendo este fato suficiente para criar um contexto temporal no qual é inserido o nome do compositor. No entanto, ainda que seja possível aprender sobre a história da música somente com a leitura de textos, esse é o "conhecimento de segunda 
mão" a que se fez referência antes (SWANWICK, 1994). Para que o aprendizado ganhe vida e se torne "de primeira mão", é essencial que uma gravação da peça em questão seja escutada, exigindo condições tecnológicas adequadas (como a existência de um arquivo sonoro ou de um CD e de equipamentos para ouvir a gravação). Sem os recursos para que isso ocorra, há um conhecimento factual, proposicional, mas que, para o desenvolvimento da musicalidade dos indivíduos, não substitui a experiência direta com a obra. Além de ouvir a gravação, outra maneira óbvia de utilizar A Sagração da Primavera na educação é tocá-la, seja a partir de uma partitura ou tirando "de ouvido".

A audição da obra também seria necessária para o campo de estudos da apreciação musical, possivelmente com indicações de trechos importantes e comparações com outras composições. Não existe estudo da apreciação musical sem o exemplo sonoro. Em um curso dessa disciplina realizado a distância, a leitura de textos certamente seria parte das atividades, mas como elemento secundário: o foco provavelmente estaria na música a maior parte do tempo. Já em um curso de história da música, o conhecimento informacional é bastante importante, porque grande parte dos conteúdos está baseada em fatos históricos que podem ser estudados em forma textual. Logicamente, as obras musicais também são fatos históricos, e para estudá-las é preciso ouvi-las. Portanto, o uso de exemplos sonoros é fundamental tanto para a história da música como para a apreciação musical, mas podem existir diferenças no peso que terão esses exemplos em relação ao corpo das disciplinas, dependendo dos conteúdos e dos enfoques escolhidos.

Da mesma forma, a importância que tem o uso de recursos imagéticos em estudos sobre performance musical é maior. O vídeo pode ser usado em cursos de história da música (mostrando personagens, locais e acontecimentos) ou de apreciação musical (com imagens de músicos e seus instrumentos), mas essas disciplinas podem funcionar bem somente com o áudio $^{50}$. Para o estudo de instrumentos musicais, por outro lado, a visualização dos movimentos que produzem a música é extremamente pertinente. Como já foi discutido e será reforçado mais adiante, nas disciplinas de performance é essencial que o tutor responsável tenha capacidades técnicas com os instrumentos que estão sendo estudados.

\footnotetext{
${ }^{50}$ Com essa afirmação, é estabelecida uma generalização, que pode ser contestada em casos específicos. No entanto, na maior parte das aulas de história da música ou de apreciação musical, por observação direta, pode-se constatar que os recursos de áudio são mais comumente utilizados do que os de vídeo.
} 
Para aprofundar essas observações, a seguir são analisadas algumas das áreas de estudo musical, expondo as relações entre os desafios encontrados no ensino realizado a distância e as tecnologias que contribuem para superá-los. A escolha dos seis campos de estudo (história da música, apreciação musical, treinamento auditivo, estudo de harmonia, composição e performance) foi arbitrária e não contempla outras disciplinas importantes (como arranjo ou regência), mas serve para demonstrar um amplo espectro de atividades que usualmente ocorrem em processos de ensino e aprendizagem da música.

\subsubsection{História da música}

Relembrar experiências passadas e usar essas lembranças para analisar novas situações torna desnecessário constantemente reinventar a roda. Por outro lado, a tradição pode enrijecer a ação imaginativa e tornar difícil, se não impossível, que músicos e educadores forjem novos caminhos e que façam ajustes e reajam às mudanças na sociedade (JORGENSEN, 2003: 41).

O estudo da história da música busca a contextualização da produção dos seus principais compositores, marcando os momentos importantes para o desenvolvimento das tradições musicais e estabelecendo ligações com outras áreas históricas, como estudos políticos, sociais, raciais, religiosos e de diferentes manifestações artísticas. Assim como estas outras disciplinas, o estudo da história da música pode ser realizado tendo como base a palavra escrita, já que os conhecimentos envolvidos são mais de ordem proposicional do que procedimental. Como foi colocado anteriormente, ouvir as obras é essencial para que os estudos nessa área sejam completos, mas se deve ressaltar que cursos organizados por historiadores que não são músicos, com formação musical limitada, poderão ter um enfoque priorizando discussões sobre temas não musicais. Por exemplo, um curso sobre o tropicalismo pode ficar centrado nas origens e nas conseqüências desse movimento, sem trabalhar com suas contribuições artístico-musicais. Nesses casos, mesmo que não existam os meios para acessar as músicas referenciadas, ainda é possível realizar um curso a distância.

Em livros, apostilas e outras formas de material impresso sobre a história da música, é comum a existência de "discografias recomendadas", contendo listas de peças musicais que deveriam ser ouvidas para a compreensão do período histórico em questão. No início dos cursos a 
distância, antes do advento da Internet, textos escritos invariavelmente eram acompanhados de fitas cassete ou CDs, com os exemplos sonoros indicados. A Open University, no Reino Unido, ofereceu seu primeiro curso de música em 1972, e durante 25 anos manteve este formato (primeiro com fitas cassete e depois com CDs), até que as inovações surgidas com as redes eletrônicas originaram alternativas para a entrega de material. ${ }^{51}$ As oportunidades de acesso a arquivos sonoros via meios digitais, especialmente com a ampliação dos serviços de banda larga na Internet, facilitaram a escuta das obras que construíram as tradições musicais de cada época. A ubiqüidade musical tornou possível a associação de todos os acontecimentos históricos estudados com as suas sonoridades, amenizando a necessidade de buscas por discos raros.

A Internet também facilitou a escuta de diferentes interpretações de uma mesma obra. Nas gravações de estilos musicais surgidos depois da invenção do fonógrafo, tal possibilidade permite o contato com vários olhares sobre um único momento histórico. Por exemplo, pode-se estudar o surgimento do estilo jazzístico do Bebop, acontecido nos anos 1940, com registros que demonstram as sonoridades de diversos artistas. Assim, uma determinada obra pode ser analisada em diferentes versões e as técnicas de um instrumentista podem ser comparadas às de outros, oferecendo estudos que favorecem a multiplicidade e a quebra da rigidez.

Já nas gravações de músicas do "passado", ou seja, composições que surgiram anteriormente aos meios de registro sonoro, são encontradas reconstituições artísticas a partir de partituras, que dependem da interpretação de instrumentistas do presente, envolvendo seus conhecimentos proposicionais sobre a forma de tocar e sobre os instrumentos usados. Não há como ouvir o som do cravo tocado em 1830, pois naquela época não existia a tecnologia para captar o som que o instrumento emitia; permaneceu apenas o que ficou registrado na forma de notação musical, em textos e imagens iconográficas. Dessa maneira, existe o acesso a todas as performances gravadas a partir do início do século XX, mas o que aconteceu antes pode apenas ser recontado por intermediários.

No trabalho com este material, o papel do tutor em um curso sobre história da música é orientar o aluno na utilização dos recursos disponíveis, responder perguntas e promover discussões. Para realizar tais tarefas, é possível utilizar os mesmos meios que servem também para a distribuição de conteúdos: correspondências e Internet, sem a necessidade de vídeos do

\footnotetext{
${ }^{51}$ Em 1997 a Open University passou a usar a Internet como meio para a entrega de materiais didáticos na área de música, e em 2007 o primeiro curso totalmente online foi disponibilizado.
} 
professor. O elemento visual é usado como ilustração, com imagens de compositores e fatos históricos, e filmagens de músicos em ação complementando os textos e exemplos musicais, que podem ser enviados fisicamente em CDs ou digitalmente pelo computador. Entre as contribuições da captação de vídeo ao estudo histórico da música, podem ser citadas a conservação de imagens de instrumentistas em movimento, permitindo análises futuras de suas habilidades e comportamentos; entrevistas com artistas compositores, que podem discursar sobre suas inspirações e metodologias de trabalho; e explanações de educadores musicais, com a chance de inserção de exemplos práticos de suas propostas, demonstrados em atividades educacionais filmadas.

Sistemas de comunicação assíncronos podem ser usados para a resolução de dúvidas, debates e avaliações. Fóruns são meios que oferecem tempo para reflexão e análise de questões, possibilitando a elaboração de argumentos complexos e bem sedimentados. Um único tópico pode gerar várias linhas de discussão, nas quais todos vêem as postagens de todos e cada resposta possivelmente serve para solucionar dúvidas de vários estudantes.

A história da música, diferentemente das áreas que serão mencionadas em seguida, em alguns momentos pode levar a atenção de mestres e aprendizes para temas distantes do estudo musical. Como dois elementos complexos estão envolvidos ("história" e "música"), poderão ser exigidas leituras de contextualização que tratam de assuntos pertinentes, mas distantes do foco musical. Temas, por exemplo, que poderão estar ligados somente às letras, e não às canções de que essas letras fazem parte ${ }^{52}$. Nesse caso, a discussão se torna mais histórica (no sentido político, religioso, social, racial) do que musical. Embora não ocorra desenvolvimento da musicalidade nesse momento, há um aprendizado muito importante: fatos são observados com uma perspectiva ampla e pluralista, podendo modificar a compreensão do presente. Afinal, "a única forma de continuar uma cultura ou uma civilização é resistir ativamente ao processo de fossilização e atrofia, e rejuvenescê-la ou transformá-la” (JORGENSEN, 2003: 41).

\footnotetext{
${ }^{52}$ Exemplos desse tipo de leitura são encontrados em Words and music, curso oferecido pela Open University do Reino Unido. Detalhes no endereço eletrônico http://www3.open.ac.uk/courses/bin/p12.dll?C01AA317.
} 


\title{
5.3.2 Apreciação musical
}

\begin{abstract}
Ouvir é como respirar ou comer: a maioria das pessoas faz sem instruções diretas. Mas assim como especialistas no corpo humano têm sugestões para que se possa respirar mais eficientemente e nutricionistas têm princípios sobre como comer bem, também os educadores musicais têm diretrizes sobre como ouvir mais efetivamente, para tirar o máximo da música, focando nossa atenção para o maior impacto musical possível (FLOWERS, 2003: 28).
\end{abstract}

O estudo da apreciação musical ocorre essencialmente por meio de escutas dirigidas, focando a atenção do ouvinte em aspectos relevantes. Usualmente, os recursos básicos utilizados são gravações e indicações dos pontos de interesse em texto ou áudio. Nesse aspecto, uma diferença surge entre aulas presenciais e o ensino em ambientes virtuais: presencialmente, o professor pode controlar o volume da música estudada e fazer intervenções a qualquer momento, mas em um curso realizado a distância, não há controle sobre as condições de escuta do aluno. Por isso, dificuldades podem ocorrer caso sejam destacados elementos que não são perceptíveis em situações inadequadas. Por exemplo, se o professor fizer referência aos contrabaixos de uma orquestra, na aula presencial é possível ajustar o aparelho de reprodução sonora, baseado na qualidade da gravação e do sistema de som disponível, para melhor escutar os instrumentos que atuam nas regiões graves. Se um arquivo sonoro é enviado por e-mail, não se conhece o equipamento que será utilizado para abri-lo e não se sabe se os ajustes necessários serão feitos. No entanto, a forma de trabalho é a mesma, buscando acentuar a compreensão do aluno sobre as obras musicais.

Assim como acontece com a história da música, o estudo da apreciação musical freqüentemente gera interesse em indivíduos que não são músicos, tanto quanto para músicos profissionais e não-profissionais. Um exemplo de curso a distância direcionado a diletantes sem experiência de leitura musical é "Comece a ouvir música" (Start listening to music), oferecido pela Open University do Reino Unido ${ }^{53}$. Com a duração de 12 semanas, este curso propõe escutas dirigidas de composições clássicas, populares, jazzísticas e de world music, destacando os instrumentos tocados e as relações com a sociedade na qual as obras foram criadas. Mesmo sem utilizar a notação musical, vários conceitos básicos da música são estudados (entre os temas listados estão estruturas e formas, sons e texturas, repertórios e estilos, e contextos de escuta).

\footnotetext{
${ }^{53}$ Um sumário com os conteúdos do curso estão em http://www3.open.ac.uk/courses/bin/p12.d1l?C01A179.
} 
Para Copland (1939), cursos de apreciação musical podem aprofundar a escuta além do simples prazer de apreciar os sons. Este compositor considera a escuta musical em três diferentes níveis: o plano sensorial, em que se escuta sem pensar e há uma fuga da realidade presente; o plano expressivo, em que a música é analisada para descobrir o "significado por detrás das notas" e a linguagem verbal é usada para descrever as reações humanas; e o plano puramente musical, aquele em que a música existe em termos das notas e suas manipulações, melodias, harmonias e formas. Na observação de Copland (1939: 18-23), normalmente apenas os músicos profissionais são conscientes do terceiro plano, mas todos deveriam ser preparados para compreender o material musical dessa forma.

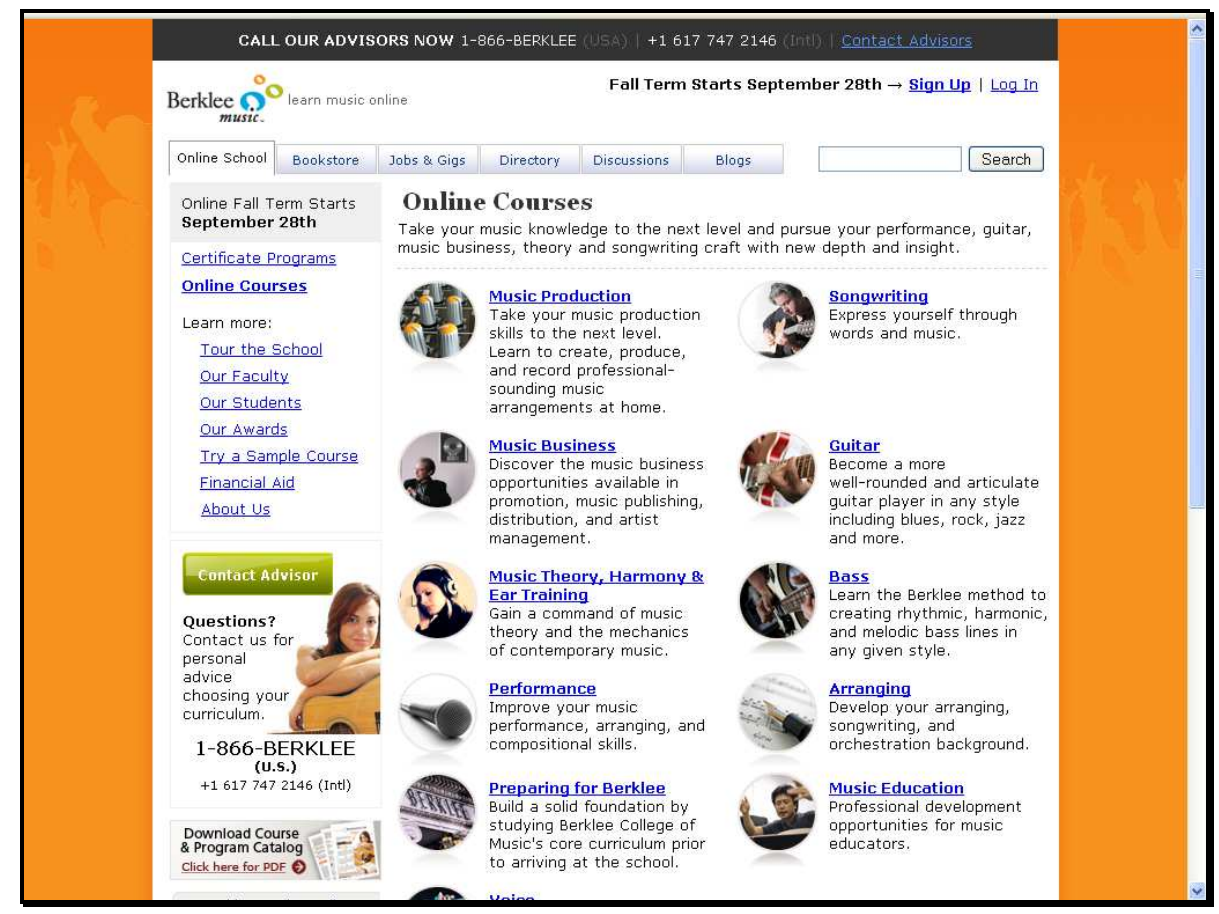

Figura 5: cursos online da Berkleemusic

Programas educacionais voltados a músicos profissionais podem incluir análises e comparações complexas entre as dimensões musicais e suas relações. Um exemplo é Critical listening, oferecido no website da Berkleemusic (http://www.berkleemusic.com) ${ }^{54}$. Também com

\footnotetext{
${ }^{54}$ A Berklee School of Music, situada em Boston, nos Estados Unidos, criou uma divisão chamada Berkleemusic para oferecer cursos de extensão via Internet para o estudo de harmonia, treinamento auditivo, softwares de gravação e editoração de partituras, arranjo e performance, entre outras opções. Com a boa reputação educacional dos seus programas presenciais, certamente há uma valorização, por parte dos alunos e do mercado de trabalho, dos certificados e diplomas obtidos com a conclusão de uma sequiência de cursos online dessa instituição. E,
} 
a duração de 12 semanas, este curso propõe a escuta de gravações a partir dos processos de produção da música, identificando técnicas e efeitos de mixagem (como panning, reverb, delay, compressão e distorção) e diferenciando sonoridades específicas de determinados instrumentos (como as guitarras Telecaster, Stratocaster e Les Paul, e os pianos elétricos Wurlitzer e Rhodes). A especificidade do programa se revela mais útil para músicos e produtores musicais do que para o apreciador comum, que provavelmente não iria conhecer muitos dos termos tecnológicos a que as escutas dirigidas se referem.

O campo da apreciação musical passou por diversas mudanças causadas pelos recentes adventos das tecnologias digitais, que facilitaram a distribuição de arquivos sonoros contendo música. Com o universo de informações que cresce exponencialmente na Internet, a humanidade caminha para um mundo de ubiqüidade musical. Tal cenário foi montado a partir de sistemas de compartilhamento de dados como o Napster, o primeiro de uma série de programas objetivando que usuários da Internet pudessem acessar gratuitamente os arquivos existentes em computadores de outros usuários.

O compartilhamento de arquivos não apenas torna possível encontrar uma obra facilmente, mas também permite que usuários explorem territórios não familiares. Se alguém pode imaginar um determinado tipo de música, isso provavelmente existe; se existe, provavelmente pode ser encontrado na Internet (KATZ, 2004: 166).

Ciente de que todos com acesso à Internet poderão, em teoria, escutar a gravação de qualquer música que existe, o professor que organiza um curso de apreciação musical pode utilizar este fato para organizar as experiências de seus alunos. Exercícios comparando diferentes interpretações de uma mesma obra são possíveis, sendo que a responsabilidade de encontrar os materiais de escuta pode ser dividida com o aluno. O exemplo de uma orientação nesse sentido seria: "encontre gravações de três versões diferentes da música Summertime, de George Gershwin, e estabeleça comparações baseadas nos conteúdos estudados na última aula”. Práticas dessa natureza estimulam um uso guiado da Internet e colocam em evidência as vantagens de

demonstrando uma tendência que também pode ser constatada em outras universidades, as disciplinas realizadas a distância contam créditos acadêmicos para alunos regularmente matriculados nos programas de estudos presenciais, oferecendo alternativas que resultam com o mesmo peso no histórico escolar do aluno. O plano de estudos do curso Critical listening está no seguinte website:

http://www.berkleemusic.com/school/course?course_item_id=2141033\&program=music_production. 
estudar online. Os alunos de cursos a distância contam com a vantagem de, recebendo seus materiais no computador, alternar com um simples apertar de teclas entre seus conteúdos de estudo e os sons e imagens da Internet.

Logicamente, alunos de cursos presenciais também podem acessar a rede, mas para eles há uma dificuldade em compartilhar os resultados da pesquisa que foi sugerida acima. Numa sala de aula, provavelmente o professor teria que selecionar algumas das versões de Summertime que considerou interessantes, viabilizar a reprodução dessas músicas (que podem estar em diferentes formatos, como arquivos MP3 e vídeos do YouTube), e organizar discussões seqüenciais sobre cada uma delas. No ambiente virtual, como todos os alunos estão online, as indicações acontecem com a simples postagem de links para os arquivos; a reprodução das músicas em qualquer formato é facilitada, pois todos estão utilizando computadores; e as discussões ocorrem em forma de rede, abrindo caminhos simultâneos de ramificações para outros assuntos relacionados.

Conversar sobre música é uma atividade muitas vezes prazerosa e natural. Mas, como coloca Flowers (2003), isto pode ser desenvolvido e refinado com o uso de um vocabulário musical específico. Esta autora destaca a importância da capacidade para descrever a música em palavras analítica, metafórica e emocionalmente. Sabe-se que um indivíduo não é incapaz de diferenciar sons apenas por não dominar as terminologias para descrever o que está escutando. Por exemplo, quando são tocadas duas notas no piano, separadas por um intervalo de duas oitavas, uma pessoa talvez não saiba responder qual daquelas notas é mais grave e qual é mais aguda, mas isso não indica que a diferença entre os dois sons não seja percebida. O que ocorre é que o indivíduo não sabe associar o som que está escutando com os conceitos de grave e agudo. Da mesma forma, freqüentemente alunos percebem elementos musicais, mas têm dificuldades em expressar suas idéias e opiniões porque não conseguem encontrar as palavras adequadas. Quando os termos corretos são utilizados e um vocabulário comum é estabelecido, a troca de idéias, opiniões e informações é facilitada e discussões mais profundas poderão ser estimuladas.

Qualquer esforço para descrever música tem como extremos a objetividade das referências técnicas e a subjetividade do gosto pessoal, com todas as variáveis existentes na combinação entre os dois. Em suas pesquisas, Flowers (2003) constatou que ouvintes inexperientes usualmente escolhem uma categoria de descrição para falar sobre música, sendo que nomear os instrumentos conhecidos na peça ouvida é a categoria mais comum. Mencionar o 
tempo, dinâmicas e melodias são outras possibilidades, assim como a utilização de linguagem figurativa, com metáforas e associações emocionais. O recurso de indicar preferências - "gosto" ou "não gosto" - também é amplamente usado. Após várias experiências, o ouvinte começa a relacionar suas idéias temporalmente, comparando elementos presentes no decorrer da peça e fazendo referência a múltiplas categorias descritivas.

Um curso de apreciação musical realizado a distância, com interações entre os participantes em ferramentas como os fóruns, exige a verbalização de idéias e descrições musicais e contribui para o desenvolvimento do conhecimento musical formal. Ou seja, as pessoas têm que traduzir o que escutam em palavras. No percurso inverso, a leitura do que está escrito promove exercícios de escuta ativa, que, a partir do acervo de arquivos disponíveis na Internet, contribuem para desenvolver a musicalidade dos indivíduos.

\subsubsection{Treinamento auditivo e estudo de harmonia}

Sem o suporte de alguma forma de análise para ajudar a focar atenções e explorar experiências mais profundas, a música facilmente se torna um fundo para outras transações simbólicas. Certas vezes isso pode ser bom, mas não devemos assumir que a educação musical não faz diferença, nem aceitar ingenuamente que ela fará. Tudo depende da qualidade da transação e da compreensão de que intuição e análise interagem mutuamente (SWANWICK, 1994: 40).

Da mesma forma como ocorre com a apreciação musical, o treinamento auditivo, parte do que é chamado de "percepção musical", exige escutas com uma qualidade sonora suficientemente boa para a demonstração de fenômenos musicais como intervalos entre alturas e cadências de acordes. Conceitos matemáticos como "uma oitava" (intervalo entre doze semitons) podem ser explicados textualmente, mas somente com a audição das alturas correspondentes ocorrerá a assimilação do que essa organização dos sons representa. Algumas situações no estudo da harmonia apresentam casos semelhantes, pois as relações sonoras que regem o encadeamento de acordes e cadências são usualmente ensinadas com partituras e apenas com a exemplificação sonora estes conteúdos estarão demonstrados por completo. O estudo de percepção e de harmonia

\footnotetext{
55 A percepção musical envolve muito mais do que o treinamento auditivo para o reconhecimento de intervalos e acordes. Especialmente com a segunda geração de educadores musicais, como George Self, John Payter e Murray Schafer, a partir da segunda metade do século XX, o conceito de "percepção musical" foi expandido e passou a lidar com muitas outras questões, incluindo todo tipo de objeto sonoro e paisagens sonoras (FONTERRADA, 2005).
} 
forma a base para uma compreensão musical avançada, que será atingida com a combinação entre o que se escuta, o que se interpreta e o que se executa (produz) musicalmente.

Para que o aluno possa avançar em alguns desses campos são necessários exercícios contínuos, repetidos exaustivamente para que as diferenças entre as sonoridades estudadas sejam assimiladas e internalizadas. Em uma situação presencial, tal procedimento pode ser realizado com o uso de um piano, no qual o professor toca duas ou mais notas, simultâneas ou consecutivas, e pede ao aluno que identifique os sons, sem visualizar a ação de seus dedos nas teclas. Com as novas tecnologias, após o advento dos softwares de música, surgiram algumas facilidades consideráveis para o estudo: o computador propõe vastas quantidades de combinações de exercícios, corrigindo erros incansavelmente e sem a necessidade do auxílio de outro indivíduo, e vários alunos podem estudar simultaneamente em um mesmo espaço, com o uso individual de máquinas e fones de ouvido.

Websites como o Musictheory.net são recursos valiosos tanto em cursos realizados a distância como de maneira presencial, oferecendo lições e exercícios para aprender a teoria e praticar a discriminação de intervalos, escalas e acordes. Embora esse tipo de programa seja encontrado em softwares instaláveis em computadores, vendidos comercialmente (CD-ROM), os conteúdos abertos da Internet possibilitam acesso gratuito, a partir de qualquer máquina conectada a rede, garantindo a continuidade do mesmo sistema em diferentes locais de estudo ${ }^{56}$. Para o treinamento auditivo, como já foi observado antes, pode-se avaliar facilmente a capacidade do aluno para identificar intervalos e acordes, mas outras áreas da percepção musical apresentam muitas variáveis complexas, quando são estabelecidas relações entre os sons e outros conceitos. Portanto, no treinamento auditivo realizado a distância, o suporte ao aluno pode ser parcialmente automatizado, mas sem garantir uma reflexão ou a aplicação dos exercícios em favor de processos educacionais mais significativos.

A afirmação acima exemplifica os dois tipos de feedback observados por Tony Bates na educação a distância (BATES, 1995: 52). O primeiro ocorre em atividades individuais, isoladas, em que há uma interação entre o aprendiz e o material de aprendizagem; o segundo em atividades sociais, quando acontece uma interação entre dois ou mais indivíduos sobre o material de aprendizagem. Enquanto um estudo amplo da percepção se beneficia da interação social, para que

\footnotetext{
${ }^{56} \mathrm{O}$ software do Musictheory.net também pode ser baixado do website e depois instalado em computadores não conectados à Internet, garantindo seu uso mesmo em locais sem acesso à rede. Outro exemplo, também gratuito e específico para o treinamento auditivo, é o site http://www.miles.be, desenvolvido por Alain Benbassat.
} 
discussões sejam travadas sobre as inúmeras possibilidades nas relações entre os sons, certos exercícios para o treinamento auditivo funcionam de forma individual, quando o desenvolvimento do aluno depende de sua insistência em praticar e testar-se com o auxílio do computador.

$\mathrm{Na}$ harmonia musical, a análise das relações entre sons muitas vezes demanda estudos comparativos em que o primeiro tipo de interação (entre aprendiz e conteúdos educacionais) é muito importante. Na estruturação de acordes, por exemplo, a diferença entre uma tríade maior e outra menor está no intervalo entre a fundamental e a terça (maior ou menor). Para que o aluno compreenda a questão, além de textos e partituras, é preciso que ele tenha acesso ao som de tríades maiores e menores, em um exercício de escuta que visa diferenciar as características dos dois tipos de acorde. No entanto, em questões mais complexas, quando há espaço para diferentes interpretações nas análises musicais, há uma necessidade de reflexão e discussão, inviabilizando o uso de sistemas automatizados. Saber reconhecer intervalos e acordes é apenas parte dos estudos necessários para o desenvolvimento da musicalidade.

Swanwick (1994: 43) definiu dois tipos de análise: primária, lidando com os elementos essenciais da compreensão musical, implícitos sem o uso de palavras em toda experiência musical; e secundária, que consiste em discursos reflexivos sobre uma música em particular. $\mathrm{O}$ autor distingue estes processos dos processos de coleta de informações proposicionais sobre o contexto da música, como fatos sociológicos e históricos, que apenas fornecem vocabulário para análises secundárias. Enquanto a análise primária está mais ligada à notação musical tradicional, a secundária pode utilizar várias formas de notação, assim como palavras, movimento físico, desenhos e outras representações metafóricas.

Pode-se assumir que programas de computador (como o Musictheory.net) facilitam a análise musical primária, ao menos em questões básicas, atuando com sistemas automatizados. A análise secundária, entretanto, depende da interação dos alunos com seus professores, tutores e colegas, utilizando formas de comunicação variadas, que podem incluir imagens em movimento. Mas, assim como nas disciplinas da história e da apreciação musical, para o treinamento auditivo e para o estudo da harmonia usualmente o vídeo é somente uma ferramenta adicional. O recurso sonoro é o considerado indispensável, sem o qual não é possível iniciar e desenvolver trabalhos. 


\title{
5.3.4 Composição
}

\begin{abstract}
A razão para a compulsão de uma criatividade renovada, me parece, é que cada nova composição traz consigo um elemento de autodescoberta. Eu preciso criar para me conhecer, e como o autoconhecimento é uma busca sem fim, cada novo trabalho é apenas uma resposta parcial para a questão "quem sou eu?", criando a necessidade de seguir para as outras partes da resposta (COPLAND, 1952: 41).
\end{abstract}

Diversos recursos tecnológicos têm facilitado o estudo de composição musical realizado a distância. As características da chamada WEB 2.0, na qual usuários não apenas acessam conteúdos na Internet, mas também contribuem para a construção de sites, criam possibilidades de trabalhos composicionais colaborativos com amplas perspectivas pedagógicas. A rápida velocidade de trocas de dados nas redes eletrônicas, cada vez mais acessíveis e com custos decrescentes, permite tanto a composição em partituras, como a realização musical em si, incluindo a definição de timbres e a edição do resultado sonoro final com efeitos digitais.

Um exemplo do primeiro caso, com notação musical, é o site Noteflight (http://www.noteflight.com). De uso gratuito, o serviço disponibilizado nesse endereço eletrônico torna possível a criação de partituras, que podem ser impressas ou armazenadas no site e acessadas mediante uma senha. Com tal recurso, um documento pode ser modificado por indivíduos em diferentes partes do mundo, criando condições para que professores coloquem seus alunos em contato para desenvolver composições coletivas. Em março de 2009, uma mensagem do professor Alex Ruthmann, da Universidade de Massachusetts, circulando em listas de discussão online ${ }^{57}$, buscava parceiros para um projeto nesses moldes. O possível envolvimento de grupos de várias nacionalidades certamente é um elemento estimulante para a participação de alunos, pois dá uma nova dimensão a projetos que, de outra forma, ficariam limitados pelas paredes da sala de aula.

Outros casos mostram trabalhos de composição colaborativa que lidam diretamente com o material sonoro, como a pesquisa realizada por Seddon (2006). Em seu projeto, esse professor uniu quatro alunos ingleses e quatro noruegueses na utilização do software Musit Interactive para criar peças musicais, conjuntamente, via e-mail. O programa escolhido tem como característica um quadro para comentários escritos, que foram usados para justificar as modificações feitas nos

\footnotetext{
${ }^{57}$ A mensagem do professor Ruthmann foi acessada na lista de discussão da ATMI (Association for Technology in Music Instruction), uma associação americana direcionada para estimular o uso de tecnologias no ensino da música (http://atmionline.org).
} 
arquivos trocados. A experiência não utilizou notação musical convencional, pois apresentava um sistema de "arraste e solte", em que trechos pré-gravados, já instalados no software, são adicionados a outros produzidos pelos próprios alunos. A análise dessa pesquisa considerou o “diálogo musical”, ou seja, as alterações e complementações nas composições, e os diálogos escritos, estabelecidos nos textos anexados a cada contribuição realizada. Os resultados demonstraram que quanto mais avançados eram os aprendizes, mais o diálogo ocorria musicalmente, sem a necessidade de explicações textuais, enquanto os menos avançados recorriam a descrições verbais mais freqüentemente.

Um exemplo de maior envergadura, em relação ao número de indivíduos envolvidos, é o Vermont Midi Project (http://www.vtmidi.org), realizado por uma associação sem fins lucrativos que reúne mais de 40 escolas de diversos níveis de ensino nos Estados Unidos ${ }^{58}$. Esse projeto foi desenhado para o desenvolvimento das composições de alunos, que são criadas presencialmente, em sala de aula, com softwares de notação musical. Em seguida, as peças compostas são encaminhadas para a avaliação de compositores profissionais a distância, resultando em um sistema de tutoria online para o aperfeiçoamento musical dos alunos. Grande ênfase é dada à crítica e à reflexão sobre as aprendizagens no processo, seguindo parâmetros estabelecidos para os alunos e seus "mentores" na prática da composição.

No Brasil, as pesquisas de Ficheman et al. (2003) tiveram como resultado o software Editor Musical, disponível por meio do ambiente virtual Edumusical (http://www.edumusical.org.br). Os sistemas desenvolvidos por essa pesquisadora e sua equipe apresentam propostas de atividades de composição musical para iniciantes, em modos individuais e colaborativos, sem o uso de notação ou de instrumentos musicais convencionais. Uma grade serve como espaço de composição, onde sons são colocados com o mouse do computador, após a seleção do instrumento que deverá soar. Na mesma linha, o programa Sibelius Groovy, da empresa americana Sibelius (http://www.sibelius.com) usa sons típicos da selva e da cidade para colagens sonoras; e o software GarageBand, da empresa Apple (http://www.apple.com), oferece um vasto banco de arquivos sonoros pré-gravados e funções de "arraste e solte", não exigindo experiências musicais anteriores para a produção de músicas. Em meio a todos os exemplos citados, a facilidade para a realização de projetos composicionais é grande, levantando a seguinte

\footnotetext{
58 Segundo a organização escolar nos Estados Unidos, no Vermont Midi Project participam escolas dos níveis elementary school, middle school e high school.
} 
questão: em que sentido pode-se afirmar que há de fato um "processo educacional", no qual indivíduos desenvolvem e amadurecem a sua musicalidade?

Nas situações em que a tecnologia é utilizada para a colaboração de alunos, a aprendizagem pode decorrer de comentários de professores (como no Vermont Midi Project) ou de colegas (como na pesquisa de Seddon mencionada acima). A distância entre os participantes em projetos como esses pode ser um fator bastante positivo, por aguçar a curiosidade sobre o que pessoas diferentes, em locais distantes, têm a dizer sobre as composições produzidas. Nos outros casos, há uma facilitação de acesso a partituras (como no site Noteflight) ou a meios de fazer música sem conhecer notação musical convencional (Editor Musical, Sibelius Groovy e GarageBand). São exemplos de ferramentas que, se utilizadas dentro de um contexto favorável, poderão contribuir de forma significativa na educação musical, especialmente de crianças. Quando usadas como "brinquedos" isolados, podem servir como um tipo de estímulo, mas que perde força e tem resultado limitado se o interesse no divertimento decair. Sem dúvida, o elemento lúdico desses softwares é extremamente positivo, assim como em qualquer atividade musical. Mas, para que esse aspecto seja aproveitado educacionalmente, deve haver uma contextualização. Em comparação com um programa para a edição de textos, pode-se dizer que o uso do Microsoft Word facilita a produção de um livro, mas não torna o escritor melhor. Da mesma forma, o uso dos softwares de música facilita a criação musical, mas não faz compositores melhores.

O que as ferramentas tecnológicas podem fazer é desmistificar a atividade de composição, tornando-a mais acessível a crianças e iniciantes em geral. Como observou Salles (2002), usualmente a criação musical não integra métodos de iniciação musical, por ser considerada o último degrau de aprendizagem, uma "sobremesa picante", que pode ser saboreada somente após o domínio de muitos conhecimentos técnicos e históricos. Nos softwares de "interfaces amigáveis", que não utilizam notação convencional necessariamente, o ato de compor é exposto de forma simples e sem mistérios, simplificando o início do processo de musicalização. Não é preciso se ater a regras, não é necessário tocar um instrumento musical, não há censuras ou restrições. Mais tarde, depois do envolvimento com o material sonoro, "a criação e a invenção musical despertam no aprendiz o desejo por uma técnica e por uma teoria musical, inclusive as notações" (SALLES, 2002: 10). 
Como aspecto inovador, as tecnologias da Internet também abrem alternativas para formas de avaliação que mostram o desenvolvimento dos alunos não apenas para a escola. No formato de blogs ou podcasts, o alcance das composições produzidas chega até toda a sociedade, até mesmo a outros países.

Em um ambiente em que é fácil publicar para todo o globo, é cada vez mais vazia a sensação de pedir aos alunos para entregar suas tarefas para uma platéia de uma única pessoa. Quando nos deparamos com um mundo achatado, em que a colaboração é a norma, forçar os alunos a trabalhar sozinhos não faz nenhum sentido (OLCOS, 2007: 18).

Seja na educação presencial ou a distância, ao tomar consciência de que o produto de suas atividades não ficará restrito à gaveta do professor, provavelmente os alunos irão valorizar ainda mais suas criações musicais. O aumento de dedicação conseqüente é uma contribuição significativa para os processos de ensino e aprendizagem da música. Existem espaços na Internet que podem ser ocupados, seja por iniciativa do professor, gratuitamente, a exemplo do projeto de Alex Ruthmann, usando o Noteflight, ou por ação das instituições, com investimentos e patrocínios, como ocorreu na construção do portal de educação musical do Colégio Pedro II (http://www.portaledumusicalcp2.mus.br), no Rio de Janeiro. Nesse caso, o patrocínio da empresa Petrobrás resultou em um site com conteúdos e atividades para os 13.000 alunos do colégio, incluindo exercícios e partituras para flauta-doce, violão e coral (LEME et al., 2008).

O ensino de instrumentos musicais é o tema do tópico seguinte, apresentando questões que serão diretamente enfrentadas no objeto de estudo da pesquisa, a partir do próximo capítulo.

\subsubsection{Performance}

Começar a tocar um instrumento é sair em uma viagem de exploração que não tem fim, e portanto não tem objetivo; nós precisamos não pensar em virtuosidade futura, mas apenas em experiência presente (SMALL, 1996: 200).

O ensino da performance é um dos principais desafios para a educação musical a distância. Por se tratar de uma área procedimental e diretamente relacionada com os movimentos do fazer musical, a aprendizagem de instrumentos musicais trabalha com conceitos práticos, que 
usualmente são discutidos com a presença de mestre e aprendiz em um mesmo espaço. Estando o aluno distante de seu professor, é essencial que, em algum momento do processo educacional, ocorram interações visuais entre eles, para que as nuanças das performances realizadas e pretendidas sejam discutidas. Textos e gravações de áudio podem verbalizar procedimentos para obter as diferentes sonoridades possíveis com um determinado instrumento, e partituras ou formas de notação alternativas podem ensinar músicas ou os princípios básicos de alguns instrumentos. No entanto, a demonstração dos movimentos da performance, com todos os detalhes, para que seja criada uma desenvoltura significativa com instrumentos musicais, demanda um elemento visual.

O aprendiz desenvolve sua destreza no instrumento com práticas regulares, em certos momentos imitando seus mestres e músicos preferidos. O que é estudado, em seguida, deve ser aplicado em atividades com sentido adequado ao aprendiz (tocar uma música ou improvisar sobre uma base sonora, por exemplo). Podem ser usados exemplos que envolvem múltiplas variáveis, muitas vezes definidas de acordo com as características físicas dos indivíduos, adaptando gestos, posturas e técnicas. Nesse caso, não funcionam sistemas do tipo one size fits all, ou seja, situações sem feedbacks personalizados para cada aluno, visando valorizar suas facilidades e contornar suas dificuldades.

Em aulas presenciais, o professor usualmente demonstra suas técnicas ao aluno e em seguida observa-o em sua performance para tecer comentários e sugestões, procurando falhas percebidas somente a partir de determinados ângulos de visão. Em contrapartida, o aprendiz tem chances de observar o mestre em busca de atalhos para seu desenvolvimento, muitas vezes encontrando respostas não verbalizáveis para atender suas dúvidas. Esse cenário se repete em conservatórios e em universidades, onde as aulas de instrumento tradicionalmente são individuais, enquanto em outras áreas as turmas podem ser compostas por mais de 100 alunos em uma única sala de aula. Tal diferença muitas vezes causa questionamentos por parte de gestores educacionais, que não compreendem situações envolvendo o professor e um único aluno.

A transposição do contato visual necessário para os estudos musicais realizados a distância pode ocorrer com o uso do vídeo, desde que existam condições favoráveis na qualidade da transmissão de imagem e som, com captações apropriadas para cada tipo de instrumento. Entretanto, na realidade da EAD, especialmente em cursos formais, usualmente existem grupos 
com vários alunos, e não há possibilidade de atenção individual do professor para cada um deles. Nessa situação, a responsabilidade do tutor (ou de outro encarregado de dar feedback) é elevada.

O tutor de um curso a distância sobre performance deve, ao menos parcialmente, dominar as técnicas instrumentais sobre as quais os conteúdos são construídos, para então compreender as etapas enfrentadas pelos alunos no processo de aprendizagem. A demonstração de exercícios pode acontecer em vídeos gravados pelo professor, mas após as tentativas iniciais dos estudantes em praticá-los, cabe aos tutores a tarefa de orientar, estimular e corrigir erros. Se não houver um entendimento das dificuldades encontradas, não há como prestar auxílio. Por exemplo, em um curso de percussão, um vídeo sobre o pandeiro poderá servir como referência para um padrão rítmico tipicamente executado naquele instrumento, exibindo os movimentos necessários para sua produção sonora. É essencial que, ao longo do processo de reconstrução daquele padrão rítmico pelos alunos, feedbacks mostrem eventuais problemas e apresentem sugestões para alcançar melhores resultados. Mesmo que o tutor não seja completamente proficiente com o pandeiro, é importante que tenha um bom domínio sobre ele e que saiba apontar as questões relevantes na performance dos alunos.

Se os procedimentos para tocar um instrumento não são demonstrados presencialmente pelo tutor ou pelo professor, a utilização de vídeos pré-gravados torna-se um recurso importante. A produção de materiais imagéticos contendo aulas de instrumentos musicais foi popularizada durante as duas últimas décadas do século XX, inicialmente com o uso do videocassete e depois com os recursos digitais do DVD (GoHN, 2003). Vídeos produzidos por empresas como a americana Hudson Music (http://www.hudsonmusic.com) exemplificam as linguagens desenvolvidas para o ensino de técnicas instrumentais, propiciando ao espectador a possibilidade de assistir uma mesma cena diversas vezes, em slow motion, vista de ângulos diferentes, buscando vantagens na intervenção tecnológica.

A formatação de tais conteúdos é um dos meios para suprir a não presença de um professor junto ao aluno, mas cria uma situação de uma única via, onde o aluno vê o professor e o professor não vê o aluno. Para que o caminho inverso seja percorrido e um feedback possa ser dado, o aluno também deve produzir vídeos de suas performances, o que acarreta a necessidade de equipamentos adequados. Embora o custo de computadores e acessórios de gravação de som e imagem seja mais acessível na atualidade do que em épocas passadas, não é possível desprezar as 
condições restritivas que se impõem. De alguma forma, é preciso assegurar que todos os participantes em um curso tenham oportunidades iguais para realizar as tarefas propostas ao grupo.

As restrições tecnológicas são um obstáculo para a realização de aulas síncronas por videoconferência. Há grandes dificuldades para se obter uma padronização de resultados com todos os alunos, pois para que isso aconteça, os mesmos equipamentos de captação e comunicação sonora e imagética devem existir nos locais onde estão professor e aluno: estúdios com microfones apropriados para transmitir as especificidades sonoras de cada instrumento musical, câmeras de alta qualidade que são deslocadas para captar imagens a partir de diversos ângulos de visão, e uma conexão com a Internet com ampla largura de banda para evitar problemas com latência e imprecisões entre áudio e vídeo. Mesmo que isso venha a acontecer para alguns privilegiados, a realidade de grande parte da população mundial não apresenta estas condições nos dias atuais.

Uma das ofertas para o ensino online de instrumentos musicais com aulas em tempo real está no site da Virtual School of Music (http://www.virtualschoolofmusic.com). Trata-se de uma "escola virtual” que serve como ponto de reunião para professores dispostos a ensinar alunos via videoconferência, utilizando webcams e microfones comuns, em troca de pagamentos por aulas unitárias ou cobradas em blocos ${ }^{59}$. Na atualidade, tal recurso não é utilizado por instituições como a Berklee, já citada anteriormente, que no projeto Berkleemusic utiliza vídeos pré-gravados como material didático em cursos de guitarra, teclado e contrabaixo, nunca com a intenção de proporcionar contatos online síncronos.

Experiências com o uso de videoconferência no ensino de instrumentos musicais já foram realizadas também no Brasil. Mendes e Braga (2006) relatam uma pesquisa com aulas síncronas de violão, usando o software Skype por meio da Internet comum. Os bons resultados apresentados indicam um formato possível para pequenos grupos, trabalhando com a iniciação no violão (BRAGA, 2009). A disciplina Percussão, na UAB - UFSCar, além da maior quantidade de

\footnotetext{
${ }^{59}$ A Virtual School of Music é um exemplo dos websites existentes na Internet que oferecem cursos de música organizados por indivíduos ou empresas não ligadas a instituições formais de ensino. Nessa situação, não há certificações ou validação de créditos. Uma simples pesquisa em mecanismos de busca como o Google mostra diversos casos de tais cursos, com o uso de diferentes metodologias e recursos tecnológicos variados, sendo muitas vezes negócios visando lucro financeiro, em que a continuidade do programa de estudos depende de sucesso comercial imediato. Sem o apoio de instituições sólidas, cursos online podem desaparecer repentinamente e devem ser considerados com certa desconfiança.
} 
alunos, lida com outras circunstâncias em relação ao tipo de instrumentos, pois no estudo da percussão uma forte intensidade sonora é produzida em vários momentos. Sem uma captação de áudio adequada para cada situação, podem ocorrer distorções nas transmissões, dificultando a compreensão do que está sendo tocado.

Outro recurso usado como material didático no ensino de performance é o ebook (livro eletrônico), um conteúdo em formato digital que pode conter textos, filmes, gravações de áudio e ilustrações animadas. O curso de graduação em música - licenciatura na modalidade ensino a distância, oferecido pela Universidade Federal do Rio Grande do Sul (UFRGS), no âmbito do Programa Pró-Licenciatura do Ministério da Educação (MEC), utiliza essa proposta em materiais desenvolvidos para o estudo de teclado e de violão (http://www.caef.ufrgs.br/produtos/musica). Nesse sistema o aluno não recebe um feedback, que deve ser proporcionado por outros meios.

A aprendizagem de instrumentos musicais lida com aspectos minuciosos em relação à afinação, timbres, interpretações, técnicas, entre outras questões que tradicionalmente foram trabalhadas em contatos diretos entre mestres e aprendizes. Com o avanço das tecnologias de informação e comunicação, pode-se vislumbrar o dia em que não haverá diferenciação entre aulas realizadas a distância ou presencialmente. No momento atual, ainda há grandes dificuldades para transpor o ensino de instrumentos aos meios tecnológicos, mas também há novas práticas que privilegiam as possibilidades abertas com os mecanismos digitais. $\mathrm{O}$ fato de que informações, sejam aquelas indicadas pelo professor ou passadas por ele em vídeos com a sua imagem, possam ser visualizadas diversas vezes, com orientações e explicações para rever exaustivamente, representa uma vantagem em relação à chance única de absorção que existe em uma aula presencial (quando essa não é registrada em áudio e vídeo).

Enquanto outras áreas da educação musical já encontraram soluções para muitos de seus problemas com o auxílio tecnológico, o ensino de performance a distância ainda se encontra em estágio incipiente. A presente pesquisa apresenta uma proposta visando contribuir para o desenvolvimento desse campo, para que a partir da experiência realizada com percussão na UAB - UFSCar, o ensino de outros instrumentos também seja beneficiado. Além do aprendizado de conceitos práticos para tocar os instrumentos, ao se lidar com a formação de professores para atuar na educação musical, como é o caso do curso analisado nos próximos capítulos, há de se considerar a utilização desses conceitos em atividades de criação musical. 
$\mathrm{Na}$ educação presencial, quando começaram a surgir os conservatórios de música no Brasil, no mesmo modelo dos europeus e americanos, "ensino de música e ensino de instrumentos eram sinônimos" (FONTERRADA, 2003: 195). Somente depois os métodos ativos, dando grande importância para atividades de criação, composição e improvisação, chegaram ao país e foram sendo adotados por alguns educadores. Ao invés de privilegiar poucos alunos "musicais" e excluir os "não-musicais", foi considerado que todos podiam se expressar musicalmente, numa formação integral dos indivíduos. Nesse momento, de certa forma, a visão sobre os instrumentos musicais passou de "veículos para gênios musicais demonstrarem seu talento" para "meios para expressão artística". Mas, na realidade, até hoje muitos professores ainda concentram todos os seus trabalhos apenas no desenvolvimento da proficiência técnica de seus alunos, preocupando-se mais com o produto final do que com o processo.

Provavelmente é verdade, como freqüentemente é colocado, que os padrões de performance estão se tornando mais altos; ao menos, os padrões técnicos estão se tornando cada vez mais exatos, e o jovem virtuoso vai para o mercado de trabalho com um conjunto de capacidades técnicas que faria os grandes performers do passado engasgar (SMALL, 1996: 193).

Essa situação, como diz Christopher Small (1996), pode ser tolerada apenas no treinamento de músicos profissionais, mas tem servido de modelo para a educação musical em geral, incluindo uma vasta maioria que não tem a intenção de seguir carreiras relacionadas à música. O desafio para o ensino de instrumentos é, portanto, maior do que apenas colocar em prática os movimentos para tocá-los. Considerando o perfil do aprendiz, a exigência de domínio técnico sempre deve ser balanceada com atividades para desenvolver a musicalidade e para ampliar conhecimentos gerais em relação ao instrumento estudado. A educação musical a distância, por apresentar diversas oportunidades de aprendizagens nesse sentido, abre um amplo campo de trabalhos, como será exposto nos próximos capítulos. 


\title{
6 Licenciatura em Educação Musical na UAB - UFSCar
}

\subsection{A percussão na formação de professores de música a distância}

\begin{abstract}
Uma vez Villa-Lobos incitou minha inveja ao mostrar sua coleção pessoal de instrumentos de percussão brasileiros. Depois de uma visita dessas, temos que nos perguntar: como nós conseguimos continuar por tanto tempo somente com o simples boom do bumbo e o óbvio crash dos pratos? (COPLAND, 1952: 89).
\end{abstract}

Em seu livro Music and Imagination, o compositor americano Aaron Copland revela o fascínio despertado no mundo pela grande variedade de instrumentos de percussão brasileiros. A comparação com os sons "simples e óbvios" de bumbos e pratos torna evidente a riqueza disponível para os ritmos e para a música do Brasil, construindo um patrimônio musical que é constantemente enaltecido no mundo inteiro. A percussão brasileira conta com instrumentos que são imediatamente relacionáveis com a música do país: o pandeiro e o ganzá remetem ao samba, o triângulo e a zabumba ao baião, a alfaia e o gonguê ao maracatu.

A presença da disciplina Percussão na formação de professores de música, primeiramente, serve como auxílio na compreensão da identidade cultural do Brasil. Para que as gerações futuras possam valorizar a sua própria música, é essencial que seus mestres tenham uma lapidada sensibilidade nessa área, aproveitando a riqueza que causou tamanha inveja em Copland. Ao mesmo tempo, observar os vários tipos de percussão que existem no mundo abre caminhos para discutir outras culturas e como nelas estão inseridas as músicas de cada país. Os ambientes virtuais são extremamente propícios para isso, pois a indicação de vídeos e arquivos sonoros, com discussões em fóruns, blogs e outros espaços de debate, amplia o alcance das atividades para qualquer lugar em que exista gravação sonora ou uma câmera filmadora.

Ademais, a importância da percussão na educação musical justifica-se por sua utilidade como ferramenta no desenvolvimento da musicalidade. A atenção aos detalhes de cada toque nos instrumentos, na diferenciação de timbres, na exploração das diferentes possibilidades sonoras de cada forma de tocar, exige um refinamento na percepção dos indivíduos, levando-os a ouvir complexidades nos sons que antes consideravam simples. O pandeiro, por exemplo, aparentemente pode ser um instrumento simples, com uma pele esticada em um aro, com platinelas ao redor. Mas, ao se compreender todas as nuanças e variações possíveis com ele, 
dentro de um contexto musical, há um universo complexo, repleto de alternativas.

A percussão também trabalha diretamente com aspectos rítmicos, deixando clara a visualização das relações entre movimento e som. Ao percutir, raspar, sacudir ou friccionar materiais, são usadas fontes sonoras para uma espécie de "dança" ao contrário, em que, ao invés do corpo reagir à música, acontece o inverso. Esse processo, assim como a eurritmia ${ }^{60}$ de Émile Jaques-Dalcroze, contribui para a superação da dicotomia entre mente e corpo, entre o mundo físico e espiritual (FONTERRADA, 2005: 120). Essa integração denota uma das transformações buscadas pelos educadores musicais durante o século $\mathrm{XX}$, visando processos não lineares que resultam em uma formação integral dos indivíduos (JORGENSEN, 2003). No curso da UAB UFSCar, ao lado de outras disciplinas (como Construção de instrumentos, Criação musical e Vivências em educação musical), a percussão é obrigatória e tida como um elemento importante na promoção dessa educação integral.

Mas, se a relação entre movimento e som é um dos aspectos a destacar na percussão, há uma questão vital a responder: como lidar com isso na educação a distância? Se o professor não está presente na sala de aula, nem para demonstrar os procedimentos necessários ao ato de tocar instrumentos de percussão, e nem para observar as performances dos alunos e fazer seus comentários e sugestões, como lidar com o movimento?

Conforme discutido no capítulo anterior, para trabalhar conceitos procedimentais a distância, é preciso contar com vídeos de boas qualidades imagéticas e sonoras, com iluminação, quantidade de pixels e captação de som suficientes para transmissões adequadas. Idealmente, esse contato aconteceria de forma síncrona, no que se convencionou nomear videoconferência, com professores e alunos se vendo em tempo real, podendo interagir uns com os outros.

Por três razões principais, a situação ideal (síncrona) não seria possível na elaboração da disciplina Percussão, no curso de Licenciatura em Educação Musical da UAB - UFSCar. Primeiramente, não seria possível garantir uma boa qualidade nas transmissões de vídeo em tempo real, pois os alunos possuem computadores diferentes e variados tipos de conexões à Internet; em segundo lugar, a exigência de várias atividades síncronas iria contra uma das vantagens da EAD, que é permitir aos alunos o acesso às aulas nos momentos que mais lhes

\footnotetext{
${ }^{60}$ A eurritmia é um sistema de treinamento musical criado por Émile Jaques-Dalcroze, “capaz de provocar no organismo os conflitos necessários para estabelecer o controle e o equilíbrio de resistências, e de trazer à consciência, com a harmonização de centros motores e cerebrais e com a canalização de forças nervosas, fontes não sonhadas de criatividade e vitalidade artística" (JAQUES-DALCROZE, 1967: 82).
} 
sejam convenientes; e, por último, aulas "ao vivo" poderiam funcionar bem com poucos alunos, mas seriam mais complicadas com grupos grandes, como são as turmas da UAB - UFSCar.

Aulas de percussão via videoconferência ocorrem de maneira satisfatória, especialmente no formato de "um para muitos",61, dadas as devidas condições. Utilizando o sistema de Artes e Humanidades da Internet2 (http://www.arts.internet2.edu), o caso relatado por Deal (2005) descreve uma clínica da percussionista Valerie Naranjo, realizada nos Estados Unidos em março de 2004, que foi assistida em 26 pontos do mundo, do estado americano do Alasca a Manchester, na Inglaterra. Além de tocar marimba e gyil (um xilofone africano), Naranjo fez exercícios cantados de pergunta-e-resposta com os participantes, que ela podia observar em um telão dividido em 26 quadrados. O mesmo autor também menciona as aulas por videoconferência do violonista Pinchas Zukerman, da Manhattan School of Music, que possibilitam uma agenda de encontros constantes com os alunos, apesar de sua participação em longas turnês; e as aulas no Cleveland Institute of Music, incluindo conferências intituladas Percussion Summits, com Paul Yancich, timpanista principal da Orquestra de Cleveland.

Embora Deal (2005: 75) tenha colocado algumas dificuldades técnicas relacionadas com a qualidade das transmissões nessas aulas, a participação de universidades nos projetos assegurava a existência da Internet $2^{62}$ tanto nos pontos de acesso dos professores como para os alunos. Dessa forma, sempre era utilizado um sistema de potenciais superiores a Internet comum, sem latências ou atrasos na relação entre som e imagem. Estivessem os pontos receptores nas residências dos envolvidos, utilizando computadores de diferentes capacidades e variadas formas de conexão com a Internet, dificilmente os mesmos resultados seriam obtidos.

Considerando-se as condições oferecidas no sistema da UAB - UFSCar, com equipes estruturadas para a produção de materiais, e o tempo disponível para a realização da disciplina Percussão, foi decidido que a melhor forma para trabalhar com os conceitos procedimentais é

\footnotetext{
${ }^{61}$ No formato "um para muitos", o professor tem o controle da situação e fica como foco central das atenções na maior parte do tempo. É possível dar chance aos alunos colocarem questionamentos, mas há grandes dificuldades para gerenciar perguntas em grupos grandes, ainda mais quando os alunos-espectadores estão distribuídos por vários pontos geográficos. Também existem videoconferências no formato "muitos para muitos", em que várias pessoas conversam e todas têm oportunidades iguais de participar.

${ }^{62}$ A Internet2 é um sistema com comunicações mais velozes do que a Internet comum. Além da organização da rede, o consórcio de universidades, empresas e agências governamentais que é responsável por esse sistema promove projetos para engajar a comunidade científica no progresso da Internet (http://internet2.edu).
} 
utilizar vídeos pré-gravados. Simultaneamente, esses conceitos devem estar acompanhados de discussões pedagógicas, pois, como afirma Penna (2007), "para ensinar, não basta tocar".

A formação do professor não se esgota apenas no domínio da linguagem musical, sendo indispensável uma perspectiva pedagógica que o prepare para compreender a especificidade de cada contexto educativo e lhe dê recursos para a sua atuação docente e para a construção de alternativas metodológicas (PENNA, 2007: 53).

A responsabilidade por imprimir uma perspectiva pedagógica a um curso é dividida entre todas as disciplinas de sua grade curricular. Para trabalhar a percussão na formação de professores de música, certamente é importante manter um foco na performance, mas também é necessário considerar outros elementos para assegurar uma ocupação efetiva dos potenciais espaços educacionais, em especial na educação básica. Diferentemente da escola especializada de música, na educação básica os desafios são mais amplos:

- Como lidar com condições de trabalho tão diversas da escola de música, com seu piano, quadro pautado e poucos alunos por turma?

- Como lidar com diferentes vivências musicais e, por conseguinte, com as distintas músicas que os alunos podem levar para a sala de aula?

- Como lidar com as diferentes expectativas em relação à aula de música? (PENNA, 2007: 51-52).

Ainda que um dos objetivos listados pela UAB seja atender a demanda de professores na educação básica, se deve sempre considerar também as outras áreas de trabalho, como alertou Del Ben (2003). Existem escolas específicas, conservatórios e outros locais em que a educação musical tem grande importância, onde ainda há muitos professores que se formaram bacharéis em música, mas nunca tiveram nenhuma formação pedagógica. De alguma maneira, todos os casos devem ser atendidos, proporcionando uma preparação que sirva tanto para a sala de aula da escola como para situações de ensino não-formal, como em organizações não governamentais e em projetos educacionais financiados por fundações empresariais.

Isso implica na necessidade de flexibilizarmos os percursos de formação dos professores de música, relacionando-os aos múltiplos espaços de atuação profissional, e de superarmos a concepção de formação como processo caracterizado como trajetória única (DEL BEN, 2003: 32). 
Condensar os múltiplos caminhos na formação de um professor em apenas algumas semanas é um grande desafio. A definição de conteúdos e a elaboração de materiais pedagógicos da disciplina Percussão foram pensadas no contexto das demais disciplinas da Licenciatura em Educação Musical da UAB - UFSCar, que estão listadas no quadro do anexo A, ao final da tese. Embora a percussão não seja considerada apenas no domínio da linguagem musical e a intenção de uma perspectiva pedagógica seja constante, também há uma consciência de que, em grande parte, os trabalhos realizados servem como ferramenta para uso em outras disciplinas. O enfrentamento das questões colocadas acima, lidando com diferentes condições de trabalho e com variadas expectativas em relação à aula de música, será realizado com esse conjunto de disciplinas, muitas das quais tratam especificamente das problemáticas pedagógicas.

Como contribuição da percussão para a formação dos professores, foram planejados textos, fotos e vídeos, para lidar com os conceitos procedimentais; e tarefas individuais, leituras e tópicos de discussão em fóruns, para estimular debates no ambiente virtual sobre contextualizações pedagógicas dos conteúdos estudados.

\subsection{Definição de conteúdos e elaboração de materiais pedagógicos}

No contexto de construção ou de reconstrução do sistema de ensino, não basta descrever e avaliar. Precisamos produzir idéias que antecipem o real ou que delineiem um ideal (THIOLLENT, 1985: 74-75).

A elaboração de disciplinas no sistema UAB - UFSCar é resultado de um trabalho de equipes. O professor responsável por uma disciplina, orientado por um profissional denominado "projetista educacional", organiza seus conteúdos em unidades, escrevendo textos que serão acessíveis tanto por meio impresso como pela Internet. Uma equipe audiovisual participa preparando fotos e vídeos, começando com um clipe de apresentação do professor e continuando com a seqüência de aulas que necessitam de imagens. A equipe de material impresso faz a revisão dos textos e a diagramação para publicar um livreto da disciplina. Por último, textos, vídeos e as propostas de atividades são inseridas no sistema Moodle pela equipe do ambiente virtual, mantendo um "ambiente coletivo", com os conteúdos a acessar, e ambientes específicos 
para cada pólo, para gerenciar o andamento das atividades programadas.

A preparação de um professor para o trabalho no sistema UAB - UFSCar começa com o "curso de formação docente para disciplina na modalidade a distância", no qual a coordenação geral da UAB e a coordenação específica dos cursos o auxilia na construção de sua disciplina. Esse curso ocorreu a distância, por meio do ambiente Moodle, e na experiência que serviu de base para essa tese teve a duração de 3 meses. Nesse período, são criados o plano de ensino e o mapa de atividades, considerando uma organização em "ciclos de aprendizagem" e fornecendo orientações básicas sobre o Moodle para que se possam editar conteúdos e compreender a interação de tutores e alunos nas ferramentas utilizadas. A partir do mapa de atividades, elaborado e revisado em conjunto com o projetista educacional, o professor escreve os textos das unidades e entra em contato com as equipes específicas, que irão participar da produção dos materiais pedagógicos.

Para a produção dos vídeos, roteiros foram planejados em parceria com a produtora responsável pela equipe audiovisual. No anexo B, ao final do presente trabalho, estão listados todos os vídeos gravados, incluindo as preparações iniciais (indicações para boas aquisições de instrumentos, alongamentos e aquecimentos, dicas de posturas adequadas para os estudos), e a demonstração dos exercícios propostos. A atuação da equipe audiovisual foi extremamente importante, contornando faltas de recursos (por exemplo, não havia microfones específicos para a captação sonora de cada instrumento e alguns equipamentos de vídeo utilizados eram propriedades de integrantes da equipe) e possibilitando o surgimento de um material com boa qualidade, edições bem cuidadas e padronização nos resultados. As fotos que ilustram o livreto e o ambiente virtual também foram produzidas pela equipe audiovisual, assim como a imagem que identifica a disciplina na tela de abertura no Moodle.

Após o esforço coordenado das equipes de trabalho mencionadas, foram concluídos os materiais pedagógicos da disciplina Percussão, com 5 unidades, conforme o livreto apresentado junto com a tese. Cada unidade contém textos escritos especialmente para o curso, tarefas (que incluíam atividades virtuais e a prática de exercícios com instrumentos) e estudos complementares, com sugestões para ampliar o foco dos estudos. Dois elementos principais foram selecionados, considerando os objetivos da disciplina e o período disponível de 8 semanas: o pandeiro e a prática com baquetas. Ficou evidente que a aprendizagem de instrumentos deveria 
ser básica, de maneira distinta àquela de cursos de bacharelado em performance, nos quais o objetivo é formar instrumentistas profissionais. O uso dos instrumentos em atividades educacionais deveria estar sempre em vista, para que sua utilidade fosse direta e possibilitasse uma integração com outras disciplinas do programa curricular do curso. Ao mesmo tempo, era essencial que os exercícios práticos formassem o eixo central dos trabalhos, sendo complementados pelas atividades virtuais, para que os trabalhos não resultassem apenas em conhecimentos de "segunda mão", sem proporcionar experiências com o fazer musical.

A escolha do pandeiro ocorreu por ser um instrumento tipicamente brasileiro, leve e compacto, que é facilmente transportável e serve para acompanhar vários tipos de música, principalmente com ritmos brasileiros. A capacidade para tocar com baquetas foi considerada importante para educadores musicais, pois é usada com diversos instrumentos de percussão, como o xilofone e a caixa clara, sendo útil também para aqueles interessados em aprender ritmos simples na bateria. Além disso, muitos instrumentos não convencionais (por exemplo, aqueles resultantes da disciplina "Construção de instrumentos") podem ser percutidos com baquetas, abrindo um rico universo de experimentações sonoras. Nas aulas em que a criação musical é estimulada, as técnicas para percutir, seja com baquetas ou com as mãos, poderão ser usadas para explorar objetos sonoros diversos, ajudando a improvisar com as diferentes sonoridades possíveis.

Além dos exercícios com baquetas e com o pandeiro, também foram produzidos vídeos com atividades complementares com o surdo e com o triângulo, para práticas em grupo durante os encontros presenciais. Todos os exercícios são apresentados em textos e partituras, disponíveis no ambiente virtual, que contém links para acessar os vídeos. As metas almejadas para os alunos no final do semestre foram os seguintes:

1) Com o pandeiro, tocar os ritmos de samba e baião;

2) Com as baquetas, executar uma peça para caixa clara, reunindo os rudimentos estudados, com o uso de acentos e variações das dinâmicas.

Tais objetivos foram traçados para capacitar os professores a usar a percussão de forma geral, para explorar objetos sonoros variados e instrumentos musicais tradicionais, seja com as 
mãos ou com diferentes tipos de baquetas ${ }^{63}$. São conteúdos que compõem a parcela pré-definida da disciplina, aos quais irão se juntar assuntos que surgirão nas discussões virtuais, formando um corpo de conhecimentos aberto e moldável às contribuições dos alunos. Essa maneira de agir entende a educação como uma prática social, o que implica em assumi-la como "objeto inacabado" (DEL BEN, 2001), envolvendo ações de pessoas que interagem e se influenciam mutuamente.

Como foi relatado por Brito (2001), o educador Hans-Joachim Koellreutter, importante figura na educação musical brasileira, tinha como proposta a superação do currículo fechado, "que determina previamente os conteúdos a serem transmitidos, sem averiguar e avaliar criteriosamente o que é importante ensinar a cada aluno, grupo, em cada contexto ou momento" (BRITO, 2001: 31). Na formação de professores de música, tal objetivo apresenta um desafio com duas faces: primeiro, incutir no futuro educador essa flexibilização curricular, a partir da observação de seus alunos; segundo, considerar o professor que está sendo preparado, para que o processo de formação seja adequado a suas realidades. Por outro lado, para que em apenas 8 semanas um trabalho com instrumentos de percussão tenha resultados positivos, é preciso delimitar bem os conteúdos e concentrar as atenções em uma seqüência definida de exercícios. Como afirma Del Ben (2001), embora seja preciso respeitar a individualidade e a subjetividade das aprendizagens, não se pode reduzir o ensino da música às experiências e interpretações do sujeito individual. Segundo a autora, "ao fazer, aprender ou ensinar música, cada indivíduo também leva em consideração as definições, conceitos, princípios, significados, propósitos, valores e práticas de outros indivíduos ou grupos" (DEL BEN, 2001: 262).

Essa é a parte "fechada" da disciplina Percussão, relacionada aos conceitos procedimentais e representada pelos vídeos pré-gravados. No contexto da UAB - UFSCar não há como, com perguntas dos alunos que surgem durante o curso, modificar de imediato o material que já está produzido e inserido no ambiente virtual. No máximo, o fórum de dúvidas abre espaço para questões que são respondidas de maneira escrita, sem demonstrações visuais. A menos que vídeos já existentes na Internet sirvam como exemplos, a produção de vídeos específicos para lidar com cada nova pergunta se torna inviável como prática recorrente.

\footnotetext{
${ }^{63}$ Um modelo específico de baqueta, considerado "médio", representado pelos códigos 5A ou 5B na maioria das marcas, foi recomendado para as atividades da disciplina. No entanto, um dos textos apresentados na unidade 1 discute o uso de diferentes tipos de baquetas, relacionando-os com os vários instrumentos que podem ser percutidos e discutindo como as técnicas devem ser adaptadas para cada caso.
} 
A parte "aberta" da disciplina surge com as atividades virtuais, nas quais tarefas são propostas e a partir delas "o caminho se faz ao caminhar" (BRITO, 2001: 31). Com atividades em que as experiências individuais são colocadas, as discussões seguem os trilhos estabelecidos pelos próprios alunos, fugindo da padronização e de currículos rígidos. Tanto na parte "fechada" como na "aberta", a troca de experiências entre os alunos, entre alunos e tutores, e entre alunos e o professor, é vital para o bom funcionamento da disciplina. A diferença está na flexibilidade dos conteúdos: enquanto os exercícios com baquetas e com o pandeiro são determinados de antemão, nas atividades virtuais uma tarefa é proposta e as discussões resultantes dependem da participação dos alunos. A seguir, serão detalhadas essas duas facetas da disciplina.

\subsubsection{Exercícios com baquetas e com o pandeiro}

Os trabalhos da disciplina percussão começaram antes da aula inaugural. Um primeiro vídeo, inserido no ambiente virtual coletivo do Moodle no semestre anterior, informou aos alunos que eles iriam praticar com baquetas e com um pandeiro. Foram colocadas dicas e sugeridos modelos para a aquisição desses itens, destacando a necessidade de contar com eles para estudos regulares, em casa, sem a dependência dos equipamentos existentes nos pólos da UAB. Não houve uma obrigatoriedade da compra, especialmente por se tratar de uma universidade pública, que abriga muitos alunos de baixa renda, mas foi colocada a importância do investimento para as futuras atividades profissionais.

Foi considerado que nenhum aluno tinha experiências anteriores com percussão, todos foram tratados como iniciantes. Dessa forma, os primeiros exercícios seriam simples e de fácil execução, estimulando o grupo e promovendo a participação coletiva, e inibindo comportamentos do gênero "não tenho boa coordenação para tocar percussão". Aqueles com experiência na área (por exemplo, os alunos percussionistas), por um lado iriam revisar conceitos básicos e observar a metodologia de ensino adotada, e por outro seriam de grande importância no auxílio do estudo de seus colegas.

Como preparação para as práticas com baquetas, na primeira unidade foi produzido um segundo vídeo, com dicas para comprar ou construir um "pad de estudos", simulando a superfície de um tambor. Um pad desse tipo, também chamado de "borracha de estudo", possibilita aos 
alunos tocar sem uma produção sonora intensa, sendo uma alternativa às práticas na caixa clara. Além de não causar distúrbios para pessoas nas proximidades, o estudo no pad se torna menos cansativo e pode ser realizado em qualquer local, sem a necessidade de um isolamento acústico. Somente na segunda unidade, depois que os alunos teriam os equipamentos necessários, os exercícios começaram.

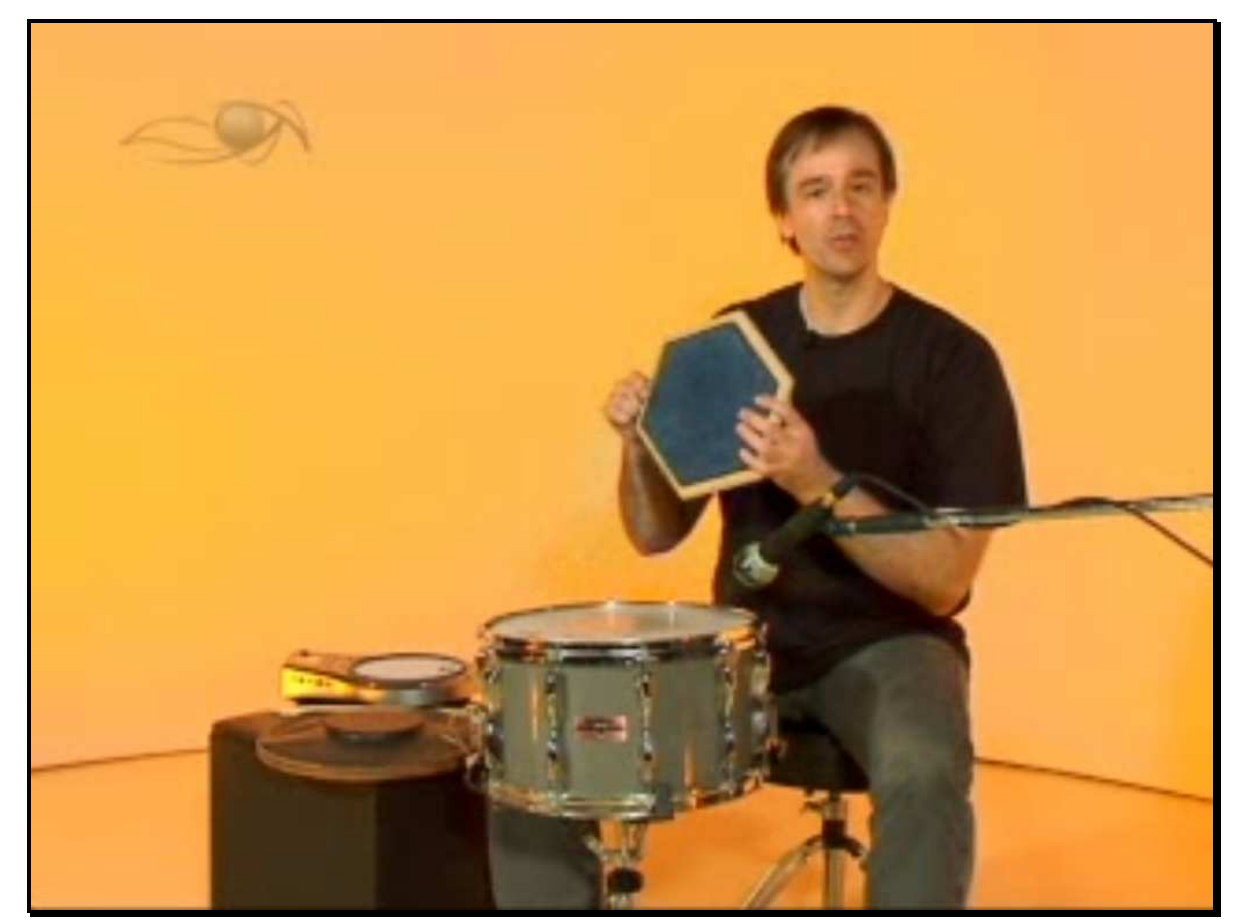

Figura 6: vídeo com dicas para comprar ou construir um pad de estudos

Com as baquetas, primeiramente foi demonstrada uma boa postura para praticar, mantendo o corpo relaxado e a coluna sempre reta, e alguns alongamentos foram recomendados, frisando que uma atenção especial deveria ser dada aos músculos dos pulsos, para que não ocorressem lesões. Em seguida, no terceiro vídeo, foi mostrada a forma para segurar as baquetas e como deveriam ser os movimentos para tocar. As informações de todos esses vídeos foram reforçadas no material impresso, com fotos e textos explicativos, como pode ser conferido no livreto da disciplina.

O primeiro exercício usou o "toque simples", alternando toques das mãos em semínimas, colcheias e semicolcheias, visando um controle sobre o espaçamento rítmico de cada ataque e o 
desenvolvimento inicial da articulação de dedos e pulsos. $\mathrm{O}$ andamento inicial indicado foi de 80 bpm (batidas por minuto), exigindo mais concentração e controle do que destreza e agilidade, para depois ser acelerado. Como alternativa ao uso do metrônomo (outra aquisição que foi estimulada, mas não tida como obrigatória), a sugestão de um serviço online (http://www.metronomeonline.com) simplificou a prática com os tempos determinados.

Nas unidades seguintes, foi estudado o "toque duplo", em que a seqüência rítmica é tocada sempre com dois toques de cada mão; e o paradiddles, uma combinação entre os toques simples e duplo ${ }^{64}$. A escolha desses exercícios se justifica por representarem a base sobre a qual todos os outros rudimentos da percussão são construídos, assegurando sua utilidade para um professor de música. Tais rudimentos foram apresentados em um documento da Percussive Arts Society (http://www.pas.org), que deveria ser "baixado" do website dessa entidade, no qual diversos outros exercícios estão listados. No entanto, a delimitação dos conteúdos restringiu os estudos aos três rudimentos mencionados acima (toque simples, toque duplo e paradiddles), ficando os demais como sugestão para aqueles que porventura se decidirem por uma especialização na percussão.

Junto com o paradiddles, foi introduzida a prática de tocar acentos, destacando algumas notas com uma intensidade mais forte; com o toque duplo, foram praticados conceitos de dinâmica, alternando compassos forte e piano, buscando um controle das baquetas nos dois extremos. Como finalização do trabalho com baquetas, na última unidade os alunos tocaram uma peça para caixa clara, unindo todos os elementos estudados, conforme pode ser observado no próximo capítulo.

Com o pandeiro, primeiramente foram colocadas as formas de segurar o instrumento e as sonoridades que podem ser extraídas dele. Nas unidades seguintes, exercícios combinaram diferentes toques para a execução dos ritmos de samba e baião, sempre destacando que se tratava do início de uma jornada, pois em poucas semanas dificilmente um novato na percussão conseguiria dominar todos os movimentos necessários para uma desenvoltura completa. Para as atividades presenciais, foram sugeridas práticas em conjunto com o uso de instrumentos de apoio: surdo para o samba e triângulo para o baião. Foram produzidos vídeos com esses instrumentos,

\footnotetext{
${ }^{64}$ A forma estudada do paradiddles, entre outras variações possíveis, é representada por dois grupos de quatro semicolcheias, com a seguinte seqüência de toques: direita-esquerda-direita-direita e esquerda-direita-esquerdaesquerda.
} 
demonstrando como poderiam ser utilizados, em exemplos simples de aplicações rítmicas com o pandeiro.

Em todos os vídeos com o pandeiro e com baquetas, a demonstração dos exercícios foi gravada sempre em dois andamentos diferentes, lento e médio, visando oferecer uma boa compreensão dos movimentos realizados. Em diversos pontos nos textos, houve discussões sobre as variadas maneiras de tocar que são possíveis, evitando uma visão única e determinista. Como segurar as baquetas, por exemplo, pode variar dependendo do tamanho e do formato das mãos do aluno, e também das características das baquetas escolhidas (peso, forma, espessura e comprimento). Enquanto os vídeos produzidos para a disciplina mostravam uma maneira "clássica" de tocar, outros vídeos, discutidos nas atividades virtuais, exemplificaram outras variações.

\subsubsection{Atividades no ambiente virtual Moodle}

O ambiente virtual de aprendizagem Moodle (http://moodle.org) é o ponto de partida dos cursos da Universidade Aberta do Brasil. Trata-se de uma plataforma gratuita para a organização de cursos a distância ou de interações online em sistemas de aprendizagem híbrida, tendo sido adotado por diversas instituições no mundo inteiro ${ }^{65}$, incluindo a Open University do Reino Unido. Contando com várias ferramentas para a elaboração de atividades, o Moodle oferece formatações específicas para cada curso, que são arranjadas em acordos com o projetista educacional. Junto com o professor, este é o principal personagem no processo de criação de uma disciplina, sendo responsável por orientar as escolhas do formato das tarefas e as etapas para que sejam desenvolvidas e postadas no ambiente virtual.

\footnotetext{
${ }^{65}$ Os dados do website http://moodle.org indicam que, em 2009, existem quase 3 milhões de cursos utilizando a plataforma Moodle, em 210 países, com mais de 31 milhões de usuários sendo beneficiados. Como o software é gratuito e o registro no sistema é voluntário, pode haver um número expressivo de cursos não contabilizados.
} 


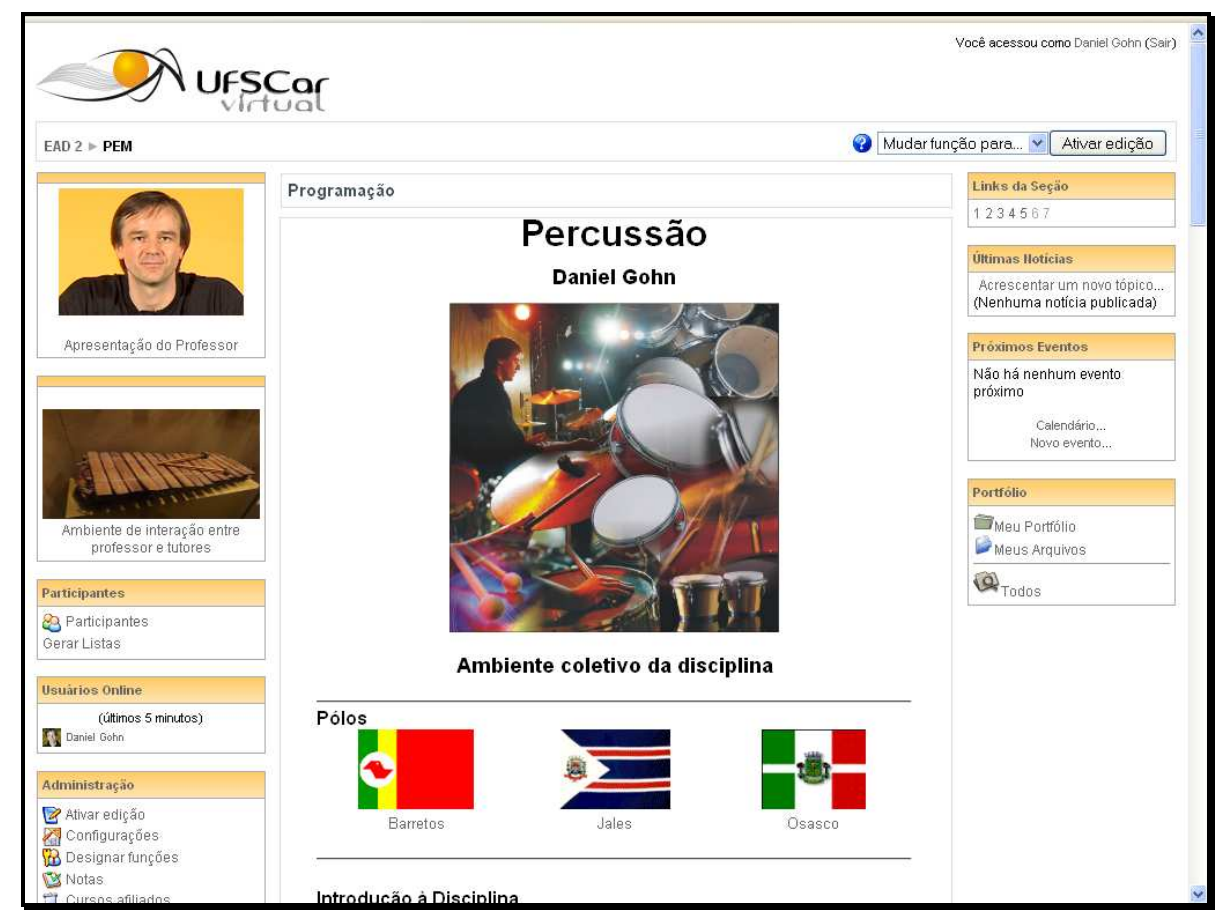

Figura 7: página inicial da disciplina Percussão no Moodle

O Moodle serve à disciplina Percussão em quatro aspectos: como meio de acesso aos conteúdos, que também são disponibilizados parcialmente em meio impresso ${ }^{66}$; como meio para divulgar as tarefas que devem ser desenvolvidas pelos alunos, tanto dentro quanto fora (as atividades com baquetas e com o pandeiro) do ambiente virtual; como meio para a realização das atividades virtuais, em que os alunos enviam trabalhos, contribuem com postagens e interagem com seus colegas; e como meio de comunicação entre professor, tutores e alunos. Seguindo a sugestão do projetista educacional, foi adotado um esquema em que as tarefas são detalhadas somente no Moodle, enquanto no material impresso há apenas instruções para consultar o ambiente virtual quando é preciso obter informações sobre as atividades a realizar. Dessa maneira, é possível modificar o curso posteriormente, fazendo ajustes a partir do comportamento dos alunos em reação a primeira oferta da disciplina. O material impresso, depois de produzido pela primeira vez, não oferece essa possibilidade, a não ser em uma eventual reimpressão, e ainda assim gerando custos complicadores.

\footnotetext{
${ }^{66}$ Todos os textos e imagens estáticas estão presentes no livreto da disciplina, mas o Moodle é a única forma de acessar os vídeos.
} 


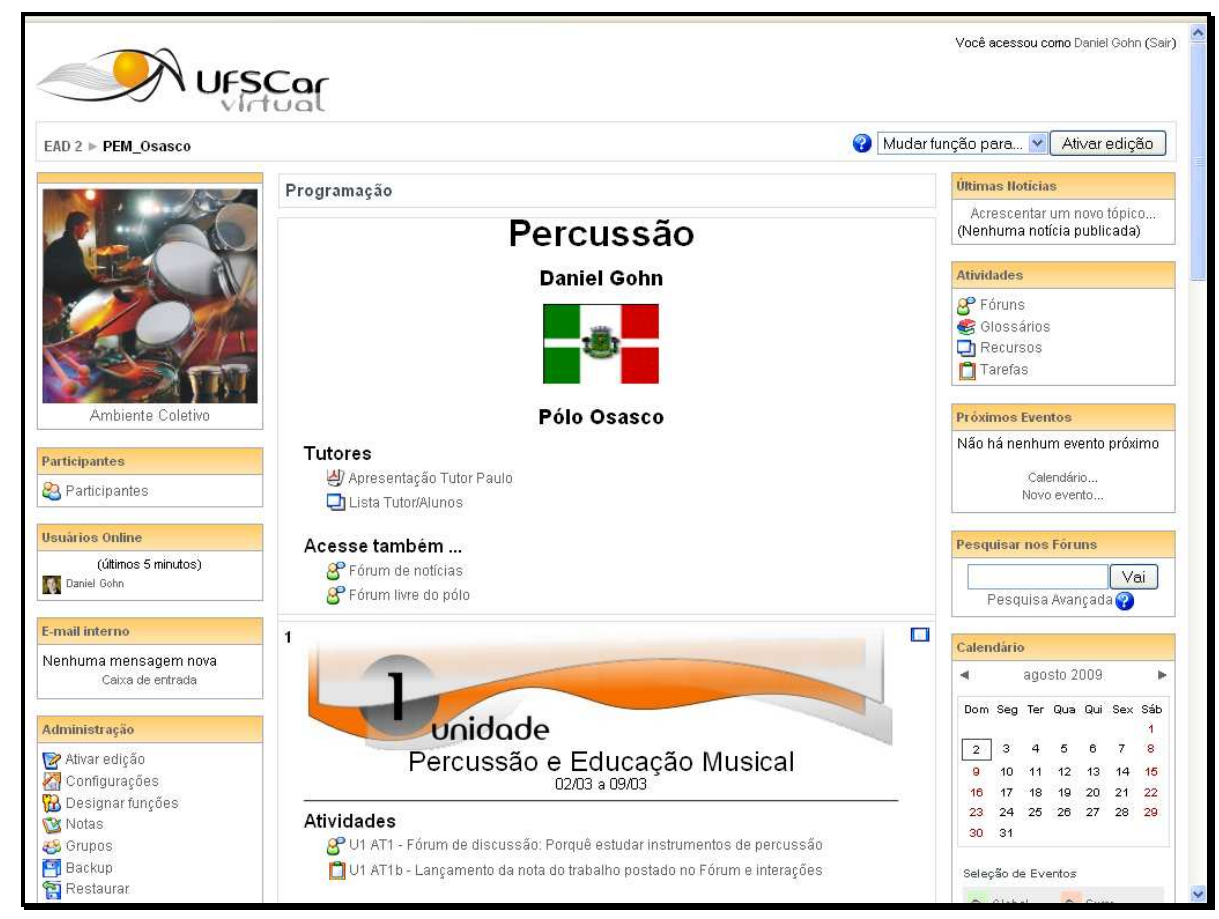

Figura 8: ambiente do pólo Osasco

Como foi mencionado antes, há dois ambientes distintos para a disciplina: o ambiente coletivo, em que são postados todos os conteúdos (textos, vídeos e partituras); e o ambiente de cada pólo, em que são colocadas as atividades de cada unidade ${ }^{67}$. Nesses ambientes específicos, os alunos interagem com o professor, com os tutores e entre si, em fóruns de dúvidas que permanecem sempre abertos, e em tarefas que possibilitam comentários, sugestões e críticas sobre o trabalho de cada um. Os alunos de um pólo não debatem com os de outros pólos. O ambiente funciona como uma sala de aula virtual, na qual estão unidos indivíduos que iniciam conversas que continuam em momentos de encontros presenciais. Como será colocado no próximo capítulo, tais conversas resultaram em assuntos diversos, relacionando o curso com as realidades e experiências individuais de cada aluno.

Para a elaboração das atividades, as seguintes ferramentas do Moodle foram utilizadas:

- Fórum: na primeira unidade, dois tópicos foram colocados em discussão - a relevância da percussão no estudo da música, e a indicação por cada aluno de um vídeo mostrando

\footnotetext{
${ }^{67}$ Tanto no ambiente coletivo como nos ambientes de cada pólo, somente no início do período reservado para uma determinada unidade é que os links correspondentes são abertos aos alunos. Antes desse momento a visualização dos conteúdos fica restrita ao professor e aos tutores.
} 
percussão, apresentando justificativas para sua escolha; na quarta unidade, os alunos enviaram e discutiram propostas de atividades educacionais utilizando algum instrumento de percussão, preferencialmente com o uso de idéias e conteúdos discutidos durante o curso; e na quinta unidade debateram sobre o processo de aprender percussão por meio de um ambiente virtual;

- Glossário: os alunos escolheram um instrumento de percussão e contribuíram para um glossário, com descrições sobre seus materiais, formato, construção, formas de tocar, principais músicos e obras que o utilizaram, entre outras informações que julgaram interessantes;

- Relato: os alunos enviaram um relato das suas práticas iniciais de percussão, durante a segunda unidade;

- Envio de vídeos: a partir da terceira unidade, os alunos enviaram gravações de suas práticas com baquetas e com o pandeiro, demonstrando o progresso de seus estudos.

Além das atividades, os estudantes também interagem nos fóruns de dúvidas, que servem para lidar com todo e qualquer assunto, incluindo questões que surgiram nos momentos de encontros presenciais. É importante lembrar que o principal acesso do professor e dos tutores virtuais ao que acontece localmente nos pólos é via Moodle, sendo o uso de e-mail e telefone mais raro. Dentro do ambiente virtual, também há um sistema de e-mail interno, que é redirecionado para o endereço eletrônico pessoal do destinatário, mas que mantém um registro de todas as mensagens enviadas. Portanto, uma consulta à caixa postal do Moodle revela o histórico das comunicações entre os participantes de um determinado curso.

Um terceiro ambiente, o "ambiente de interação entre professor e tutores", distinto do ambiente coletivo e dos específicos de cada pólo, serve para deixar o professor em contato com seus auxiliares, ajudando no funcionamento da disciplina.

\subsection{Estrutura e funcionamento}

A disciplina Percussão foi oferecida pela primeira vez no primeiro semestre de 2009, para três pólos do curso de Licenciatura em Educação Musical da UAB - UFSCar, situados nas 
cidades de Barretos, Jales e Osasco, todas no Estado de São Paulo ${ }^{68}$. Tais pólos existem nessas cidades pois o município ou o governo do estado enviou um projeto que atendeu aos requisitos anunciados em um edital, oferecendo as infra-estruturas física, tecnológica e pedagógica para que os cursos possam funcionar. Em cada pólo, uma equipe é orientada por um coordenador, incluindo um técnico em informática, responsável pela manutenção e assistência dos equipamentos eletrônicos; um bibliotecário, que organiza, armazena e divulga o acervo bibliográfico criado em cada cidade; e os tutores presenciais.

Em cada pólo do curso de Licenciatura em Educação Musical, dois tutores presenciais prestam auxílio localmente, coordenando encontros presenciais semanais ${ }^{69}$, resolvendo questões levadas pelos alunos e reportando as dificuldades encontradas aos professores. Esses tutores têm formação geral em música e trabalham para todas as disciplinas do curso, sem garantias de conhecimentos em nenhuma área específica. No caso dos pólos citados, os seis tutores declararam não possuir experiência com percussão, e cuidavam de 26 alunos em Barretos, 26 em Jales e 35 em Osasco $^{70}$. Suas atuações mais relevantes ocorrem durante os encontros nos pólos, quando se encarregam das atividades planejadas pelos professores, e nas avaliações presenciais, quando são responsáveis pela aplicação e pelo gerenciamento das provas de cada disciplina.

Conforme foi colocado no capítulo 4, a proximidade e o relacionamento entre tutores presenciais e alunos é um elemento importante para o bom andamento de um processo educacional a distância, pois são esses os únicos personagens a se encontrar face a face, de maneira constante, no decorrer do curso. Usualmente, são eles os primeiros a lidar com dúvidas, conflitos e inquietações, muitas vezes tendo que "apagar incêndios" antes de repassar as questões aos professores. O principal meio de comunicação com os tutores presenciais durante a oferta da disciplina Percussão na UAB - UFSCar foi uma sala criada no ambiente de interação entre professor e tutores, com alguns contatos emergenciais tendo ocorrido por telefone ${ }^{71}$.

\footnotetext{
${ }^{68}$ Os outros pólos do curso de Licenciatura em Educação Musical da UAB - UFSCar são Itapetininga e São Carlos, também no Estado de São Paulo, e Itaqui, no Rio Grande do Sul. Para essas cidades, a disciplina Percussão foi oferecida no segundo semestre de 2009.

${ }^{69}$ Embora os encontros nos pólos sejam semanais, nem todas as disciplinas têm tempo reservado para atividades nesses momentos. A disciplina Percussão teve dois encontros de duas horas, com duas datas alternativas para cada encontro (quinta-feira ou sábado, na segunda e na quinta semana do curso).

${ }^{70}$ Esses números são referentes somente à quantidade de alunos matriculados na disciplina Percussão, no primeiro semestre de 2009, e não ao número total de alunos em cada pólo.

71 As únicas emergências constatadas durante a disciplina foram dúvidas sobre as atividades presenciais que deveriam acontecer em um determinado dia.
} 
É preciso que os tutores virtuais tenham uma formação adequada na área da disciplina em estudo, pois irão orientar, responder perguntas, fazer comentários, realizar avaliações, entre outras responsabilidades que demandam conhecimentos específicos. Para a primeira oferta da percussão na UAB - UFSCar, houve somente um tutor virtual para cada pólo ${ }^{72}$, o que seria suficiente para o número de alunos nas turmas da disciplina. Dois desses tutores virtuais são percussionistas, e o terceiro é um baixista com bons conhecimentos em percussão. Um deles já havia trabalhado em outras disciplinas e tinha experiência na UAB, estando plenamente ciente de seus deveres e responsabilidades. Os outros dois passaram pelo curso de treinamento em tutoria virtual, exigido de todos que pretendem atuar nessa função, para aprender sobre suas atribuições e o funcionamento do ambiente Moodle.

Dois dos tutores virtuais (um dos percussionistas e o baixista) tinham sido meus alunos na disciplina percussão no curso presencial da UFSCar, em 2004. Ambos residem em São Carlos e trabalharam para o curso nessa cidade, enquanto o outro tutor (o segundo percussionista) vive na cidade de Franca. Com o professor da disciplina atuando em São Paulo na maior parte do tempo, o elemento "distância" de fato foi a realidade enfrentada, não somente com os alunos, como também no gerenciamento das atividades. Com essa situação, uma das questões que surgiu no início das aulas foi: dois tutores conhecem a forma de trabalho do professor, pois já foram alunos dessa mesma disciplina, mas o terceiro tutor possivelmente aprendeu percussão de outra maneira, com outras prioridades e uma metodologia diferente. Poderia essa diferença gerar complicações para o pólo em que ele estivesse atuando?

A preocupação com os tutores virtuais justifica-se pela importância de sua participação para o bom andamento das atividades. São eles que tecem comentários sobre cada tarefa desenvolvida pelos alunos, observando questões de interesse e estimulando o progresso dos estudos. Na disciplina Percussão, os tutores virtuais são responsáveis pelas seguintes funções:

- Nos fóruns, destacar algumas das contribuições relevantes e instigar a interação entre os alunos;

- Dar notas para todas as atividades, apresentando comentários e apontando elementos que podem ser melhorados;

\footnotetext{
${ }^{72}$ As turmas do curso de Licenciatura em Educação Musical da UAB - UFSCar podem ter até 50 alunos. Nesse caso, há dois tutores virtuais para cada pólo, cada um cuidado de um grupo de 25 indivíduos. Quando os grupos são menores, como ocorreu com a disciplina Percussão, cada turma poderá ter apenas um tutor.
} 
- Realizar o controle de freqüência, conforme será explicado mais adiante;

- Responder as perguntas postadas no fórum de dúvidas, juntamente com o professor;

- Assistir aos vídeos enviados pelos alunos, analisando a performance com baquetas e com o pandeiro e indicando passos para aperfeiçoar os movimentos demonstrados.

Todas essas obrigações são divididas com o professor, que coordena o processo e serve como referência constante para o trabalho dos tutores. A responsabilidade final de tudo que ocorre na disciplina é do professor, que deve supervisionar o que for delegado a outros. Na primeira oferta da disciplina percussão, o sistema funcionou em equilíbrio, com os tutores tendo autonomia para tomar suas decisões, mas sempre consultando o professor em questões não usuais. Para a resolução de dúvidas, alguns alunos preferiram se dirigir sempre diretamente ao professor e outros aos tutores, e sempre havia a possibilidade da intervenção de ambos nas respostas. As comunicações com os tutores virtuais ocorreram primordialmente no ambiente de interação entre professor e tutores, e por meio do Skype. O Moodle apresenta a vantagem de manter um histórico com todos os contato realizados dentro do ambiente, mas a conversação via VoIP é um recurso essencial para a solução rápida de problemas.

Outra personagem importante durante a oferta da disciplina é a responsável pela manutenção do sistema Moodle, que auxilia o professor em quaisquer situações ligadas ao ambiente virtual, como problemas de acesso e cadastro, postagens de arquivos e limites de tamanho para o envio de tarefas. Também são constantes os contatos com a secretária do curso de Licenciatura em Educação Musical, com a supervisora administrativa e com o coordenador geral. Todos apóiam o professor quanto aos processos pedagógicos, assegurando que as disciplinas estão funcionando satisfatoriamente, e também ajudam no relacionamento com os alunos, muitas vezes lidando com questões de ordem pessoal.

\subsection{Avaliação e controle de freqüência}

$\mathrm{Na}$ disciplina Percussão, os alunos são avaliados tanto pela participação nas atividades virtuais, no Moodle, como pelo seu desenvolvimento nos exercícios propostos para as práticas instrumentais. Considerando os objetivos propostos, que visam à formação de professores de 
música, e não de instrumentistas, a exigência no desempenho com baquetas e com o pandeiro é ajustada ao potencial que cada aluno demonstra ao longo do curso. Ou seja, não estará baseada em verificar quem consegue tocar mais rápido ou com mais precisão, mas sim em ajudar todos a aproveitar suas capacidades ao máximo, independentemente do ponto de partida ou de chegada.

Nesse sentido, a avaliação possibilita que o professor conheça os alunos melhor, a partir da percepção de como os exercícios são recebidos e praticados. A maior parte do grupo apresenta dificuldades na realização das tarefas com os instrumentos? Ou apenas alguns enfrentam problemas, enquanto a maioria demonstra um bom desenvolvimento? Como diz Souza (2003: 77), entre outras funções, "a avaliação pode ajudar na adaptação da proposta de ensino às condições do aluno ou garantir-lhe o esforço de continuar aprendendo". Assim como ocorre na educação presencial, quando uma turma mostra facilidade extrema no aprendizado, é possível ampliar o foco e incluir assuntos que de outra forma não seriam abordados. Pelo contrário, se houver grandes dificuldades, um reforço nos conteúdos iniciais é recomendável.

A nota final dos alunos na percussão é resultado da combinação de duas notas parciais: a virtual, que vale 4,9 da média; e a prova presencial, que vale 5,1. Tal sistema é sugerido pela coordenação do curso, em observação ao decreto 5.622, assinado pelo Presidente da República do Brasil em 2005, que exige uma avaliação presencial para cursos realizados a distância. Logo, somadas todas as atividades desenvolvidas no Moodle, chega-se à nota virtual, incluindo o envio de tarefas e a participação nos fóruns, e no final da disciplina acontece a prova presencial, baseada nos exercícios com baquetas e com o pandeiro. O gerenciamento de todas essas notas é feito no Moodle, com uma configuração realizada pelo professor, auxiliado pelo coordenador do curso. São designadas as atividades não-avaliativas (no caso de existirem aquelas que não serão contabilizadas para notas) e avaliativas, e os pesos para cada uma são inseridos no sistema.

As notas das atividades no Moodle são responsabilidade dos tutores virtuais. Para cada tarefa realizada, eles postam uma nota de 0 a 10 e deixam comentários. Ao final de cada unidade, enviam um relatório para o professor, detalhando a participação do grupo que está sob sua tutoria. As observações sobre os vídeos produzidos pelos alunos são especialmente importantes, pois orientam suas práticas futuras e apontam os erros e acertos nos procedimentos apresentados. Esse tipo de feedback é o que mais se aproxima de uma aula presencial, oferecendo atenção individual e especializada, e indicando caminhos estruturados a partir do desenvolvimento do aprendiz. $\mathrm{O}$ 
professor acompanha o processo de avaliação e toma as decisões que julga necessárias, mas o trabalho em larga escala da educação a distância demanda uma equipe, para que cada aluno seja alvo de observações atentas e consistentes.

Anteriormente ao início da disciplina, os critérios de avaliação foram discutidos com os tutores, de maneira geral, colocando em pauta os objetivos planejados. Depois, ao longo do período de trabalhos, conversas mais específicas, utilizando como referência as notas dadas nas atividades das primeiras unidades, refinaram esses critérios. Por exemplo, se a avaliação de uma tarefa com o pandeiro fosse demasiadamente rigorosa, seria lembrado que o curso está contribuindo para a formação de professores de música, logo o instrumento deve ser visto como uma ferramenta educacional. Fosse o objetivo formar um instrumentista, a exigência seria maior, pois a performance seria a prioridade. Por outro lado, se um tutor for complacente ao extremo, deixando de cobrar os resultados esperados em uma determinada tarefa, qualquer justificativa serviria para que um aluno chegasse ao final do curso sem nenhum desenvolvimento.

A prova presencial é responsabilidade dos tutores presenciais. Em algumas disciplinas, as provas são elaboradas e corrigidas pelo professor e os tutores apenas asseguram um bom encaminhamento para o dia do exame. Em outras, como é o caso da percussão, eles assumem um papel fundamental, pois atuam como observadores in loco do progresso dos alunos. Primeiramente, há uma convivência proporcionada pelos encontros presenciais, quando os tutores podem perceber as maiores dificuldades encontradas, e no final dos estudos acontece a prova, na qual avaliam a evolução de cada caso. As orientações para a prova priorizam as metas da disciplina e podem ser conferidas no anexo $\mathrm{C}$, ao final do presente trabalho.

No término da disciplina, o histórico de cada aluno permanece no Moodle, que oferece diversas visualizações para o "relatório de atividades" gerado pelo sistema. Cada acesso é registrado, marcando os percursos de estudos individuais, além das contribuições nos fóruns e dos envios de tarefas. É possível notar se um estudante freqüenta o ambiente virtual regularmente, se leu todos os textos (embora esses conteúdos estejam também disponibilizados no material impresso), e ter gráficos computando todas as atividades realizadas. Esses recursos criam condições para que os tutores virtuais avaliem os alunos de forma apropriada, a distância, enquanto os tutores presenciais têm a chance de observá-los durante os encontros do grupo e nos outros momentos em que estão nos pólos. 


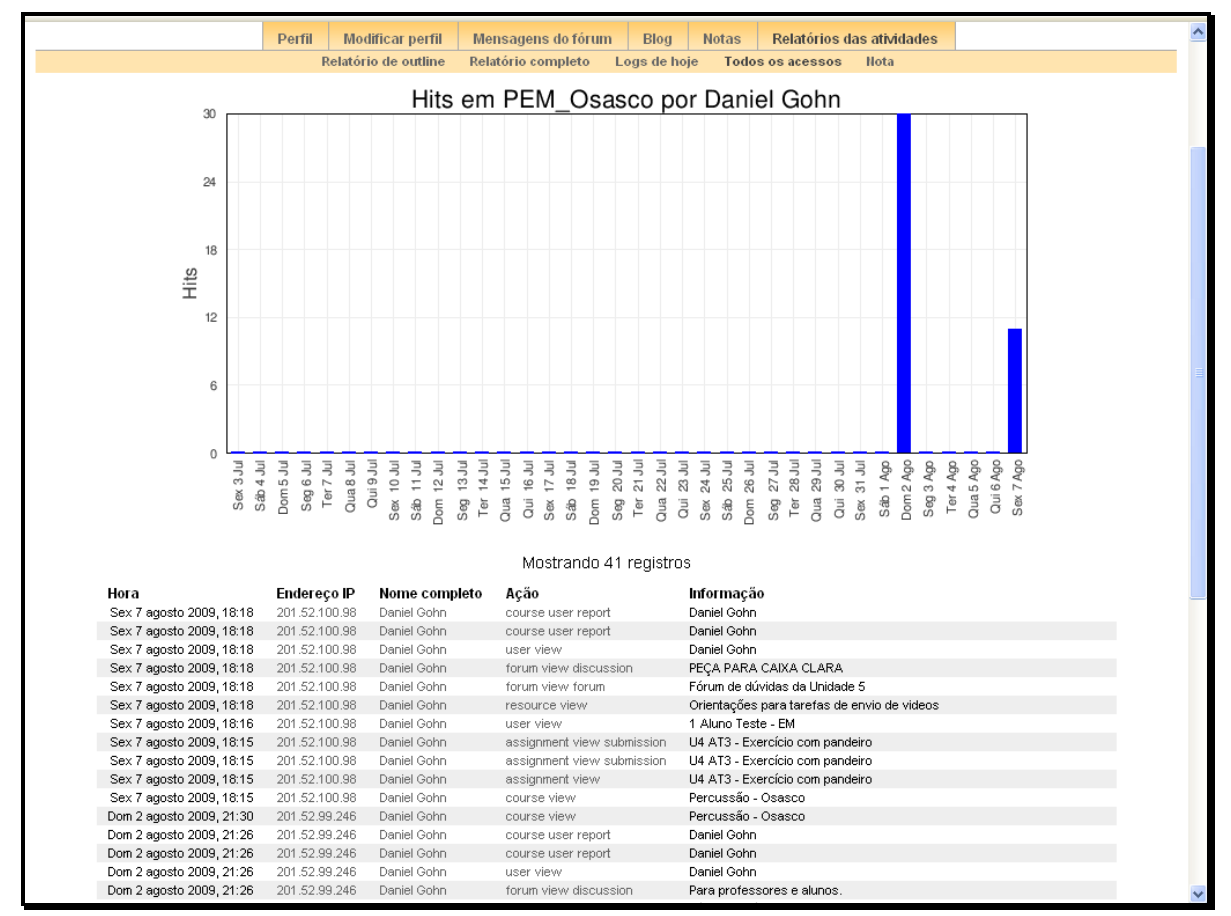

Figura 9: relatório de atividades no Moodle

O controle de frequiência é feito por meio de uma planilha elaborada pelo professor, listando todas as atividades da disciplina e o tempo estimado para que sejam realizadas. Como já foi colocado antes, o fator distância deposita muitas responsabilidades aos alunos e não é possível afirmar que um indivíduo passou um determinado período estudando um assunto. Não acontecem aulas em que o aluno esteja presente e comprove sua freqüência. Para resolver a questão, o tutor assinala uma "presença" quando for demonstrado que as etapas para a realização de uma tarefa foram completadas. Por exemplo, quando ocorre a participação em um fórum, discutindo o texto da unidade, é considerado o tempo que o aluno despendeu para contribuir na discussão e para a leitura do texto. Quando um vídeo é enviado, com a exibição dos resultados da prática de um exercício, são observados os períodos empregados na produção do vídeo e no estudo do exercício. Não se trata de um controle preciso, mas que valoriza o desenvolvimento real do aprendiz.

Em teoria, para participar de um fórum de forma significativa, seria preciso ler o texto; e para enviar o vídeo com o exercício, seria preciso ter praticado antes. Sabe-se que é possível 
burlar esta lógica, com a dedicação de menos tempo do que o necessário e a posterior alegação de dificuldades na compreensão ou na realização das atividades. No entanto, o mesmo pode ocorrer em aulas presenciais, pois não há garantias de que o aluno está concentrado e aprendendo, apenas por estar fisicamente presente. Sendo o objetivo de um curso o ensino, a comprovação da aprendizagem se torna o mais importante, independentemente do tempo investido para que ela ocorra.

No próximo capítulo, será detalhada a proposta da disciplina Percussão, na forma como foi apresentada em seu primeiro oferecimento, no curso da UAB - UFSCar. Também serão colocados alguns dos resultados iniciais obtidos, visando buscar novos caminhos para o futuro e lapidar as unidades que já foram elaboradas. 


\section{Proposta de ensino a distância de percussão}

\subsection{Resumo da disciplina}

Neste capítulo, um resumo da disciplina apresenta a proposta de ensino a distância de percussão que foi ofertada no primeiro semestre de 2009. Os textos elaborados para cada uma das unidades são baseados em experiências obtidas em aulas presenciais, quando os assuntos abordados surgiram como sendo pertinentes à formação de professores de música. O material escrito é intercalado com os vídeos, que demonstram em imagens as explicações textuais. Alguns dos temas colocados não são específicos de nenhum instrumento e lidam com o papel da percussão na educação musical. Há uma grande deficiência de literatura nessa área, especialmente que trate de aspectos variados da percussão, outros que não sejam relacionados a exercícios para a prática de instrumentos. Mais do que treinar movimentos e procedimentos para tocar, um curso de percussão para formar professores deve trazer novas formas de pensar, trabalhando com elementos variados e relacionáveis com as realidades dos alunos. Nesse sentido, os resultados iniciais obtidos, apresentados em seguida, funcionaram como "termômetro", indicando os assuntos que mais despertaram interesse e geraram participações.

Os conteúdos expostos aqui foram organizados como parte do curso de Licenciatura em Educação Musical da UAB - UFSCar. Sendo assim, os alunos já saberiam o funcionamento do sistema Moodle e estariam acostumados aos estudos realizados a distância. Anteriormente, tiveram disciplinas ${ }^{73}$ que explicitaram suas responsabilidades e passaram por dois anos de experiências no curso. Caso fossem os alunos iniciantes na educação a distância, certamente uma preparação seria parte da proposta, para explicar a dinâmica de tarefas e interações que estaria por acontecer. Tal etapa não foi necessária, visto que todos os participantes da disciplina, incluindo tutores e alunos, haviam passado por um treinamento prévio.

As disciplinas no curso da UAB - UFSCar são divididas em ciclos de aprendizagem, ao final dos quais o professor faz uma reflexão sobre o andamento da turma e estimula a participação no prosseguimento dos estudos. Na disciplina Percussão, as unidades 1 e 2 corresponderam ao primeiro ciclo, cada uma com uma semana de duração, e as demais aos ciclos

\footnotetext{
73 "Introdução à educação a distância" é a principal disciplina que lida com o funcionamento de um curso realizado a distância. Outras podem abordar o mesmo tema de maneira mais sucinta.
} 
seguintes, com duas semanas de duração cada (a unidade 3 foi o segundo ciclo, a unidade 4 foi o terceiro ciclo e a unidade 5 foi o quarto ciclo). A seguir, o conteúdo de cada unidade é detalhado, com resumos dos textos produzidos e descrições dos vídeos e exercícios propostos.

\subsubsection{Unidade 1: Percussão e educação musical}

- Texto básico para estudos:

A primeira unidade começou com uma visão geral sobre os diferentes instrumentos, estilos e tradições de percussão. O texto de introdução destacou que ser um estudante de percussão usualmente significa escolher, como objeto de estudo, apenas alguns instrumentos e algumas dessas tradições, pois o universo formado por todos os elementos existentes é grande demais para uma única vida de investigações. Além disso, para realmente entender uma determinada cultura musical, é preciso colocá-la em seu contexto de origem, relacionando-a com a forma de viver de seus músicos e com sua história social.

Para exemplificar as colocações acima, foram usados vídeos do YouTube que mostram o grupo Kodô, do Japão; a banda militar de Basel, na Suíça, assim como um conjunto de música afro-cubana e uma bateria de escola de samba. Algumas características desses grupos são apontadas, enfatizando como em cada situação a percussão ocupa diferentes espaços na música e na vida dos indivíduos. Todas as indicações de vídeos online são feitas somente no ambiente virtual (e não no material impresso), para que seja possível modificá-las e atualizá-las, no caso de algum conteúdo ser retirado do endereço eletrônico em que se encontra.

Em seguida, foi discutida a importância para um educador musical de tocar instrumentos de percussão, por possibilitarem uma clara visualização da relação entre movimento e som. Tal aspecto torna estes instrumentos bastante úteis para a educação musical, pois demonstram a fonte sonora de uma maneira evidente, facilitando a sua compreensão. O contato com a percussão promove experiências sensoriais que ligam diretamente a percepção e a produção musical ao corpo. Todos os músicos, de certa forma, estabelecem contatos com essa ligação, pois têm que organizar seus movimentos em acordo com o resultado sonoro esperado, seja qual for o instrumento. Mas é com instrumentos de percussão que o ritmo do músico é trazido à tona de 
forma mais evidente, tornando óbvias suas dificuldades e facilitando o aperfeiçoamento de sua musicalidade.

Por último, foram focados os processos de musicalização, nos quais a percussão é vantajosa porque conta com muitos instrumentos leves, simples para carregar, que facilmente são utilizados por crianças pequenas. Há muitos detalhes a perceber em qualquer tipo de percussão, e a sensibilização para essas pequenas diferenças é essencial tanto para aprendizes em seus primeiros estudos musicais como para músicos profissionais. Portanto, foi destacada a atenção necessária não apenas para a colocação rítmica das notas, mas também para as qualidades do som. Para que se perceba quantas sonoridades diferentes são extraídas de instrumentos muitas vezes aparentemente simples, foram apontados alguns dos grandes percussionistas do mundo: o porto-riquenho Giovanni Hidalgo, o indiano Trilok Gurtu, o britânico Jim Kilpatrick, os americanos Elvin Jones, Tony Williams e Max Roach, e os brasileiros Naná Vasconcelos, Airto Moreira, Marcos Suzano, Edison Machado, Milton Banana e José Eduardo Nazário.

- Atividades de aplicação, prática e avaliação

A primeira tarefa dos alunos foi adquirir um par de baquetas e um pandeiro. Um vídeo, que já havia sido disponibilizado antes do início da disciplina, elaborou alguns aspectos básicos dessa compra: que as baquetas não devem ser muito leves ou muito pesadas, que não importa se a ponta das baquetas é de madeira ou de nylon, que o pandeiro também deve ser leve (os modelos na medida de 10 polegadas foram recomendados), e que a relação entre custo e benefício deve considerar a sonoridade do instrumento. Outro vídeo foi destinado a auxiliar a compra ou a construção de um pad de estudo, mostrando alguns dos tipos existentes e como madeira e borracha podem ser usados para uma solução caseira.

No primeiro fórum, duas questões foram propostas, com as seguintes instruções:

1) Responder e discutir: todo professor de música deve estudar instrumentos de percussão? Porquê?

2) Procurar um vídeo mostrando um tipo de percussão que se considera interessante. Indicar o link, junto com um breve parágrafo analisando o vídeo. 
Concluindo a unidade 1, foi sugerida uma visita ao website Drummerworld (http://www.drummerworld.com), para a obtenção de mais informações sobre os percussionistas mencionados na disciplina.

\subsubsection{Unidade 2: Introdução à técnica de baquetas e ao pandeiro}

- Texto básico para estudos:

O principal tema da segunda unidade foi a técnica procedimental de baquetas e de pandeiro, propondo exercícios iniciais e discutindo características de alguns instrumentos de percussão. Para uma introdução a esse assunto, o texto produzido foi dividido em 3 partes. A primeira sobre baquetas, a segunda sobre a relação entre baquetas e diferentes instrumentos de percussão e a terceira sobre o pandeiro.

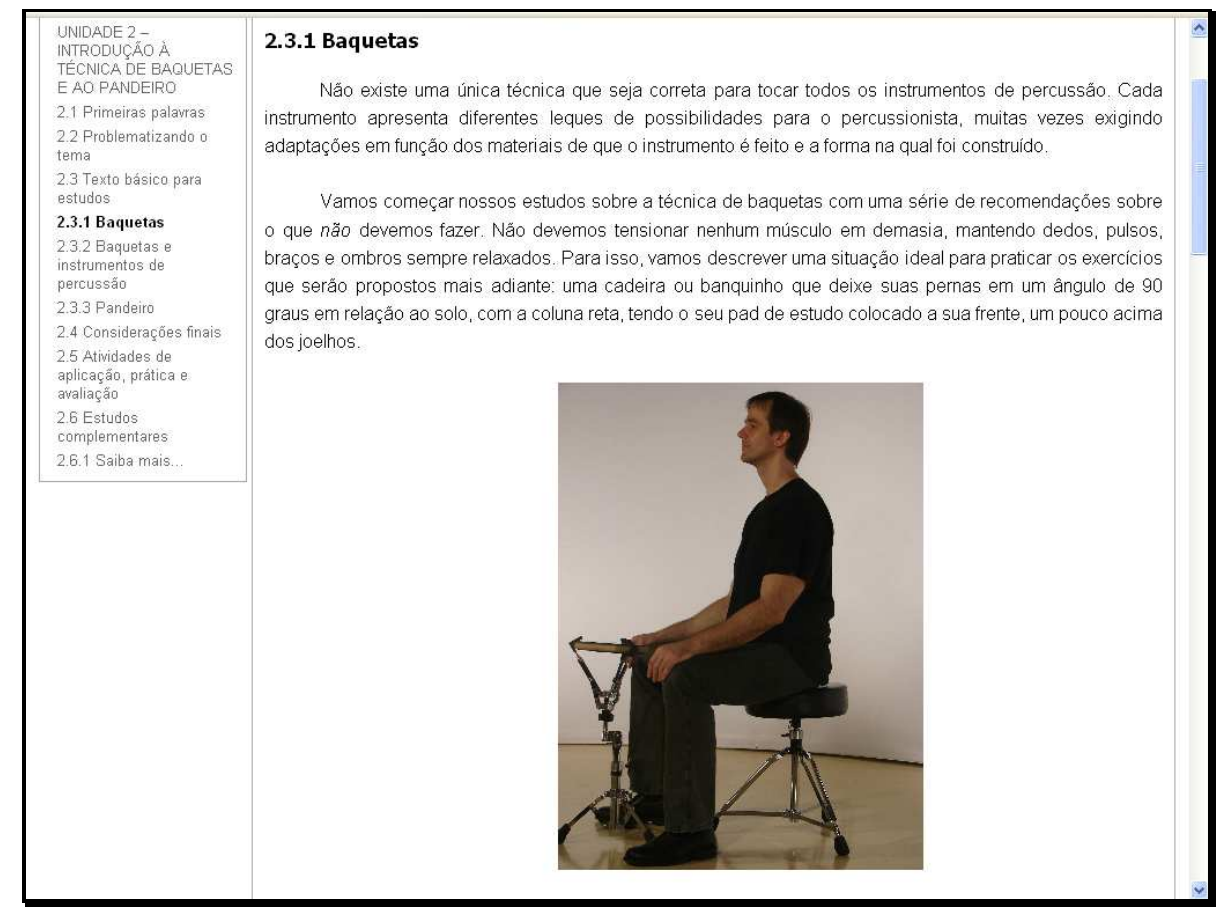

Figura 10: indicação da postura para praticar com baquetas 
Na primeira parte, foi descrita uma situação ideal para praticar os exercícios que seriam propostos: uma cadeira ou banquinho que deixe as pernas do aluno em um ângulo de 90 graus em relação ao solo, com a coluna reta, tendo o pad de estudo colocado a sua frente, um pouco acima dos joelhos. Em seguida, imagens estáticas demonstraram aquecimentos e alongamentos para os pulsos e um vídeo mostrou como segurar as baquetas. Outro vídeo exibiu alguns dos movimentos envolvidos no ato de tocar percussão, enfatizando a necessidade de manter dedos, pulsos, braços e ombros sempre relaxados. Entre os pontos observados, foi dito que, ao praticar o exercício proposto nessa unidade, as duas mãos devem tocar com a mesma intensidade e sonoridade, as baquetas devem ser levantadas na mesma altura para todos os toques, e cada movimento deve resultar em um único som, claro e articulado em relação aos outros.

$\mathrm{Na}$ segunda parte, foi discutido como os procedimentos para tocar com baquetas devem ser adaptados às características de cada instrumento. Quando se trata de um membranofone, ou seja, se há uma membrana que irá vibrar, o diâmetro do instrumento, o tipo da membrana e a tensão aplicada a ela irão modificar a resposta que será obtida. Com um idiofone, ou seja, um instrumento em que o som é produzido pela sua própria vibração, as propriedades do material usado na construção do instrumento também alteram a maneira de tocar. Logo, as diferenças entre alfaias, xilofones, surdos e outros instrumentos de percussão demandam ações específicas, assim como baquetas que sirvam de forma apropriada a cada situação.

Na terceira parte do texto, relativa ao pandeiro, a questão da resistência muscular foi posta junto com os exercícios iniciais. Além dos alongamentos, também foram recomendados aumentos gradativos nos períodos de estudo sem interrupção, antecipando as dificuldades que os aprendizes encontrariam. A partir dessa unidade, o aluno começa uma rotina de prática diária, além da participação no ambiente virtual. Foi sugerido que esse período seja de 40 a 60 minutos diários, lembrando que é melhor estudar um pouco todos os dias do que tentar "compensar" em um único dia da semana. Tanto com as baquetas como com o pandeiro, os exercícios têm como objetivo desenvolver a memória muscular para certos movimentos, e por isso é necessário repetilos muitas e muitas vezes, até que se consiga uma coordenação fina e controlada. 
- Atividades de aplicação, prática e avaliação

O primeiro exercício prático com baquetas tratou do "toque simples", em que as mãos tocam sempre alternadas, direita e esquerda, conforme a notação apresentada:

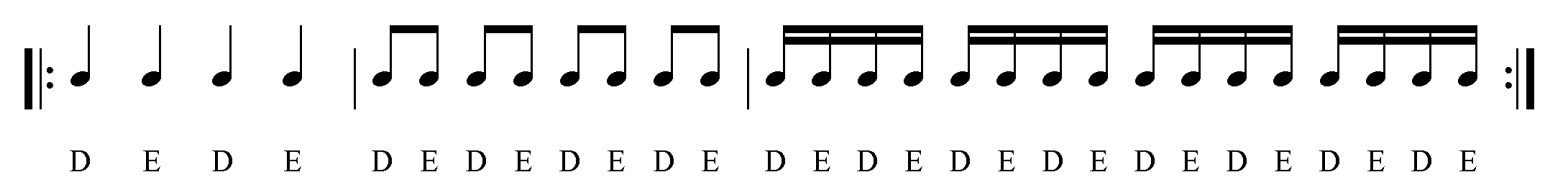

Com o pandeiro, algumas das sonoridades do instrumento foram exploradas, primeiramente buscando os sons graves, depois alternando toques do punho com toques das pontas dos dedos, com a mão em forma de concha. No segundo passo, a mão que segura o instrumento começa um leve movimento de torção, acompanhando os toques mencionados no exercício anterior.

No ambiente virtual, os alunos contribuíram para montar um glossário da percussão. Deveriam escolher um instrumento de percussão e escrever um texto de 15 a 20 linhas, descrevendo os materiais utilizados na sua construção e dissertando sobre as formas comumente usadas para tocá-lo. Foi sugerido dar profundidade ao trabalho, contemplando vários pontos sobre o instrumento escolhido e usando diversas fontes, evitando assim uma mera replicação de conteúdos da Wikipédia. Alguns websites foram sugeridos para o início da pesquisa:

http://www.bibvirt.futuro.usp.br/textos/didaticos_e_tematicos/percussoes_do_brasil http://www.percussionista.com.br/instrumentos.html http://learningobjects.wesleyan.edu/vim http://www.dancedrummer.com/museum.html

Ao final dessa unidade, os alunos tinham como tarefa um relato de suas práticas iniciais, respondendo as seguintes perguntas:

1) Na sua opinião, a leitura do material didático, os vídeos e orientações foram suficientes 
para a realização satisfatória das atividades?

2) Na realização dos exercícios, o que você considerou mais fácil?

3) Na realização dos exercícios, o que você considerou mais difícil?

4) Quais as dúvidas e/ou dificuldades sobre esses exercícios que você espera solucionar ou superar?

\subsubsection{Unidade 3: Rudimentos e samba no pandeiro}

- Texto básico para estudos:

A unidade 3 começa com uma discussão sobre coordenação motora. Para tocar um ritmo em um instrumento musical, usualmente são necessários dois tipos de coordenação: uma para controlar a combinação entre os movimentos do lado esquerdo e do lado direito do corpo; e uma coordenação "fina", que define as sonoridades que são obtidas. Por exemplo, com o piano, muitas vezes uma seqüência harmônica é tocada com a mão esquerda, enquanto a mão direita toca uma melodia. Os ritmos de cada mão podem ser diferentes, e somente com a junção deles chega-se ao resultado que interessa. Além disso, para obter um bom som com as teclas, é preciso articular bem cada nota que é tocada, exigindo todo um processo que envolve movimentos bastante controlados dos dedos do pianista.

Como mecanismo para um percussionista desenvolver esses dois tipos de coordenação, foi introduzido o estudo de rudimentos. São chamados de "rudimentos" diversos exercícios que foram criados para tocar com baquetas. Os alunos deveriam acessar o website da Percussive Arts Society (http://www.pas.org/Resources/rudiments.cfm) e fazer o download de um documento com 40 rudimentos listados, apresentados em forma de notação e gravação sonora, que é amplamente utilizado no mundo todo como referência para a aprendizagem da técnica de baquetas.

Também foi colocado o conceito de acento, quando algumas notas são tocadas mais forte do que outras. O controle entre o "forte" e o "fraco" é muito útil para tocar qualquer instrumento de percussão, e surge pela primeira vez nos exercícios dessa unidade. Nos vídeos dos exercícios, foi demonstrada a orientação para que as baquetas sejam bastante levantadas para tocar as notas 
acentuadas e fiquem baixas para executar as notas fracas. A atenção fica focada na qualidade do som que se está produzindo, ligando a extensão do movimento a um determinado resultado sonoro. O texto procura estimular a paciência dos alunos, ao insistir na questão de que a coordenação "fina" demora a aparecer. Para tocar os rudimentos como são apresentados nas gravações da P.A.S., é preciso muito tempo de prática e não se pode esperar que em um curto período qualquer indivíduo seja capaz de fazer o mesmo.

Em relação ao pandeiro, dois aspectos são destacados: a qualidade individual dos sons e a relação entre eles na construção de ritmos. Nessa unidade começa o estudo do samba, exigindo uma performance articulada e com a "ginga" típica dos sambistas, objetivo que só pode ser alcançado quando se percebe as diferenças entre um ritmo "duro" e outro "swingado". Foram recomendadas para escuta muitas músicas dentro do gênero, com artistas como Chico Buarque, Paulinho da Viola e Beth Carvalho, assim como gravações de baterias de escolas de samba.

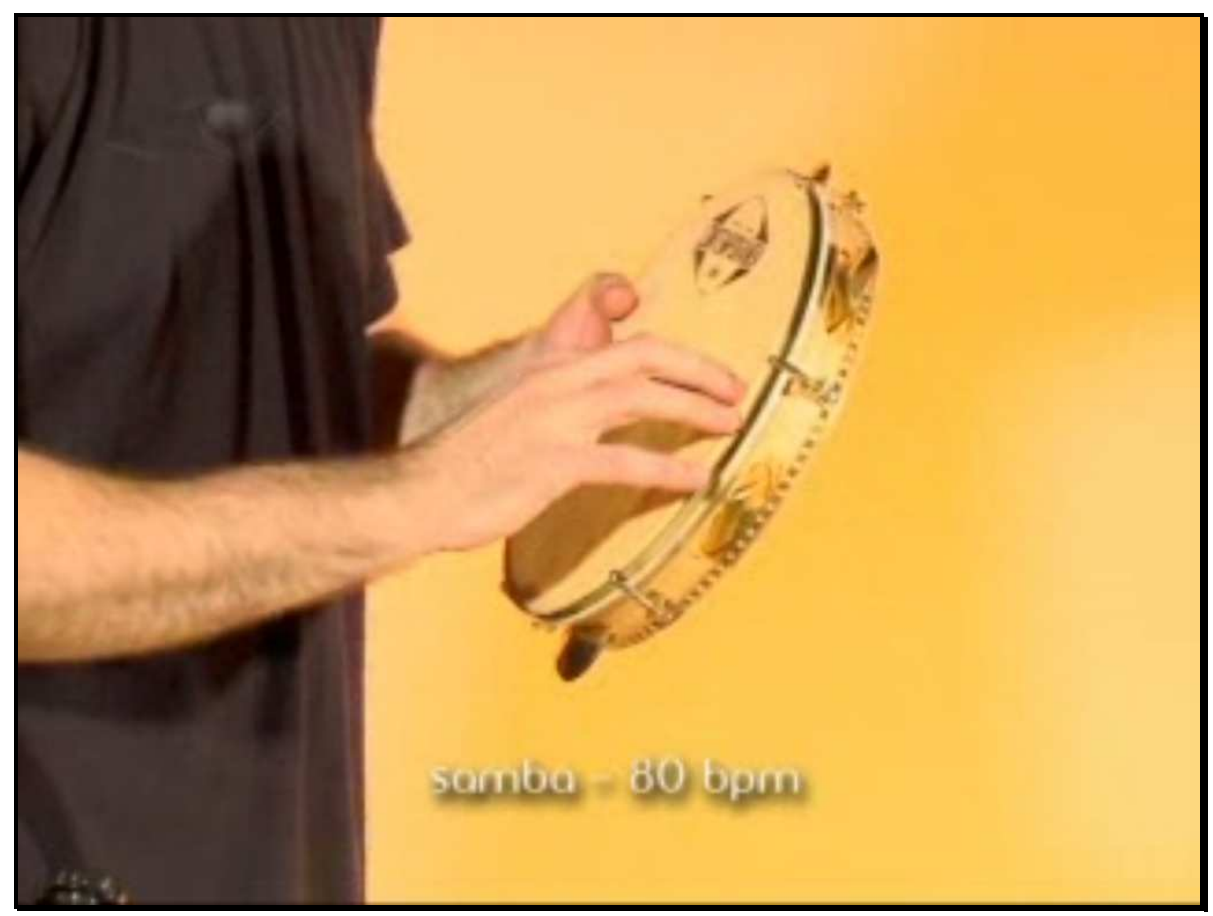

Figura 11: vídeo de samba no pandeiro 
- Atividades de aplicação, prática e avaliação

O rudimento estudado nessa unidade foi o paradiddles, como notado a seguir:

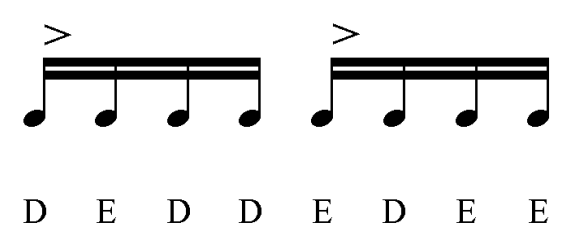

Para o pandeiro, um ritmo de samba foi apresentado. É comum encontrar a seguinte notação gráfica para o exercício, em que o sinal (+) representa o som fechado, o sinal (o) representa o som aberto, (P) significa polegar, (d) significa dedos e (p) significa punho:

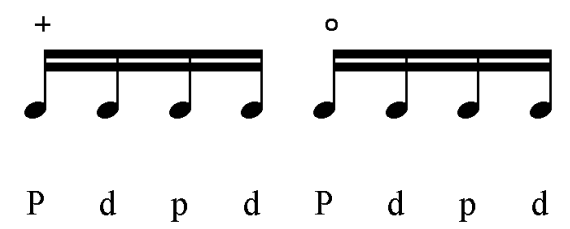

No Moodle, a partir desse momento, os alunos deveriam sempre enviar dois vídeos por unidade, cada um tendo entre 30 segundos e 1 minuto de duração, sendo o primeiro para demonstrar exercícios com baquetas e o segundo para o pandeiro. O tamanho de cada arquivo não pode ultrapassar $20 \mathrm{Mb}$, e tanto os tutores virtuais como os presenciais foram colocados como opção para auxílios na produção dessas tarefas. Aprender a produzir e a enviar esses vídeos também é uma atividade que faz parte do projeto educacional do curso, tendo como objetivo que os alunos possam potencializar suas ações com os recursos tecnológicos disponíveis, se preparando para situações que possivelmente encontrarão em seus futuros profissionais.

$\mathrm{Na}$ conclusão da unidade 3, os alunos foram estimulados a praticar em grupo, aproveitando os momentos presenciais. A proposta de estudo conjunto foi, a partir de uma melodia de choro tocada na flauta ou no violão, dois alunos tocarem percussão: o primeiro fazendo a marcação de um surdo, com uma nota abafada no primeiro tempo e outra aberta no 
segundo; e o segundo tocando pandeiro, com o ritmo que foi visto nessa unidade. A combinação desses instrumentos é a seguinte:
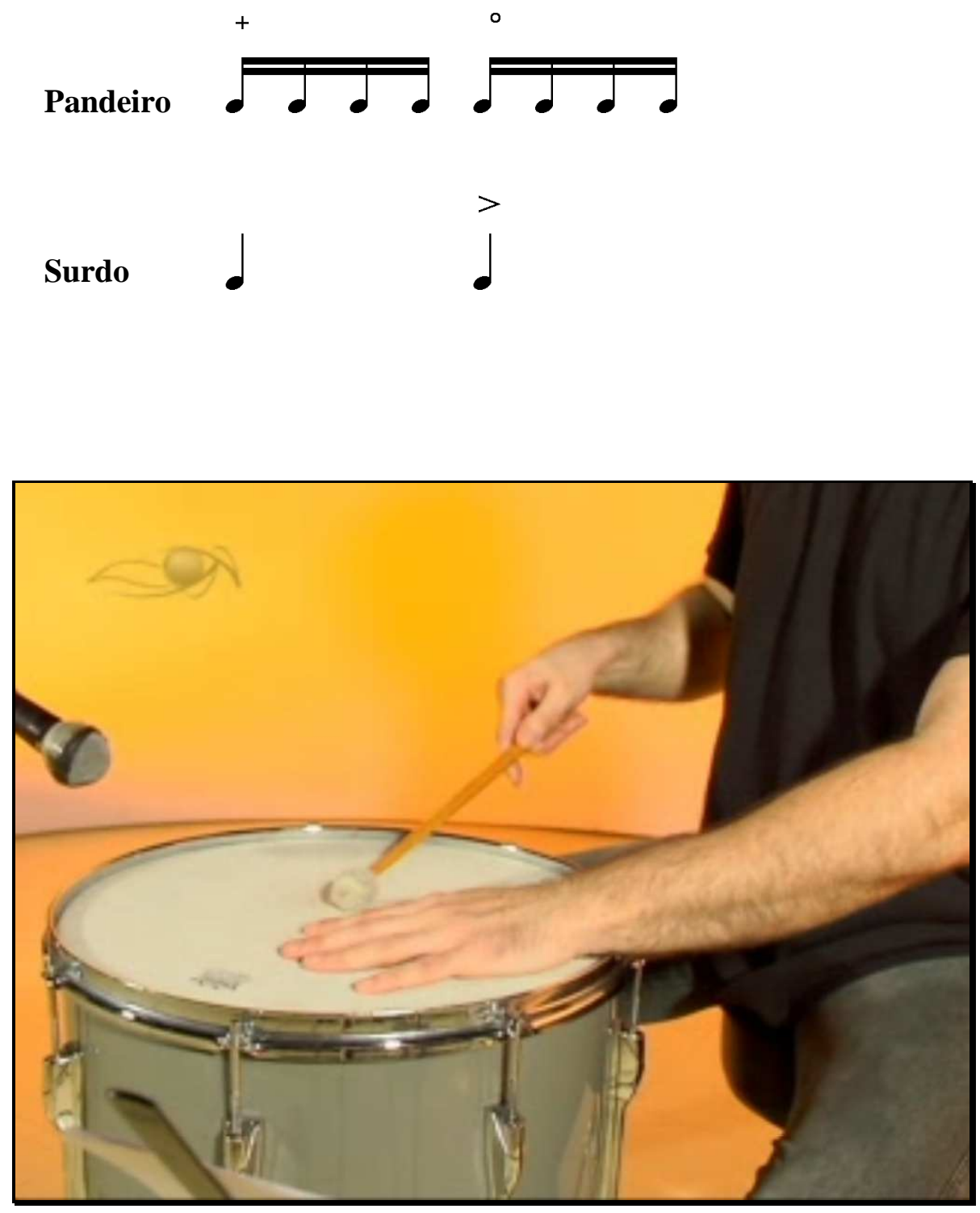

Figura 12: vídeo de estudo conjunto com o surdo 


\subsubsection{Unidade 4: A percussão como ferramenta educacional}

- Texto básico para estudos:

O texto da unidade 4 buscou relações entre o estudo dos instrumentos de percussão e as atividades do professor de música, estabelecendo pontes com as demais disciplinas do curso. A percussão é vista como complemento para o trabalho com conceitos da música e como meio para que o professor esteja envolvido em performances com seus alunos. Por exemplo, se o repertório de músicas estudadas incluir ritmos de samba, o pandeiro poderá ser usado como acompanhamento, servindo como referência para indicações de andamento e dinâmica.

Um possível uso de baquetas pelo educador musical foi ilustrado com a caixa clara, para tornar evidente a colocação de notas no tempo e mostrar a associação entre cada movimento e os sons produzidos. Da mesma forma, tocar um tambor pode demonstrar extremos de dinâmica, passando rapidamente do piano para o fortíssimo. A capacidade para tocar ritmos diversos pode ser útil, por exemplo, para explicar que o frevo é tocado sempre com a sensação de que pode “correr", pois deve soar "para frente"; e que uma balada, bem lenta, por outro lado, pode soar tão "relaxada" que passa a impressão de que irá "atrasar", em relação a uma marcação do metrônomo.

A percussão também foi citada no texto como ferramenta para atividades de improvisação e composição. Nas aulas em que a criação musical é estimulada, as técnicas para tocar com baquetas e com as mãos poderão ser úteis para expandir as possibilidades sonoras em atividades educacionais. No uso de objetos sonoros diversos, entre instrumentos convencionais e não convencionais, tal capacidade ajuda a explorar e a improvisar com as diferentes sonoridades que podem ser obtidas. Os procedimentos com baquetas e com o pandeiro podem contribuir para tocar instrumentos produzidos na disciplina "Construção de instrumentos musicais", que é parte do currículo da UAB - UFSCar. "Vivências em educação musical", disciplina do curso que utiliza diversas atividades em momentos presenciais, como danças circulares e brincadeiras de roda, oferece várias oportunidades para o emprego da percussão.

Além disso, com os recursos tecnológicos disponíveis para o professor de música na atualidade, é possível elaborar materiais didáticos incluindo gravações, nas quais a habilidade 
para adicionar acompanhamentos de percussão abre um vasto leque de alternativas. Os conhecimentos sobre instrumentos de percussão possibilitam tocar e gravar partes simples ou produzir arranjos em programas de computador que dispõem de sons sintetizados ou prégravados.

De uma forma geral, o texto dessa unidade teve como objetivo ligar a repetição contínua dos exercícios com baquetas e com o pandeiro a fins musicais. Para o educador, é essencial compreender a importância do seu estudo e situá-lo nas suas atividades futuras, pensando em atividades que envolvam elementos musicais, e não meramente mecânicos, para dar sentido ao aprendizado. Mesmo quando se pratica em um pad de estudos, que não oferece muitas possibilidades sonoras, ainda há como pensar e fazer música, trabalhando com motivos rítmicos e variações de dinâmica.

- Atividades de aplicação, prática e avaliação

Nesta unidade, o exercício apresentado é tocado com dois toques de cada mão, originando o que se convencionou chamar de "2 e 2", "toque duplo" ou "papa mama". Há dois vídeos que mostram esse rudimento: o primeiro exibe o toque duplo rápido, quando acontecem dois toques de cada baqueta para cada movimento do pulso; o segundo é com o exercício abaixo, com variações de dinâmica a cada compasso:

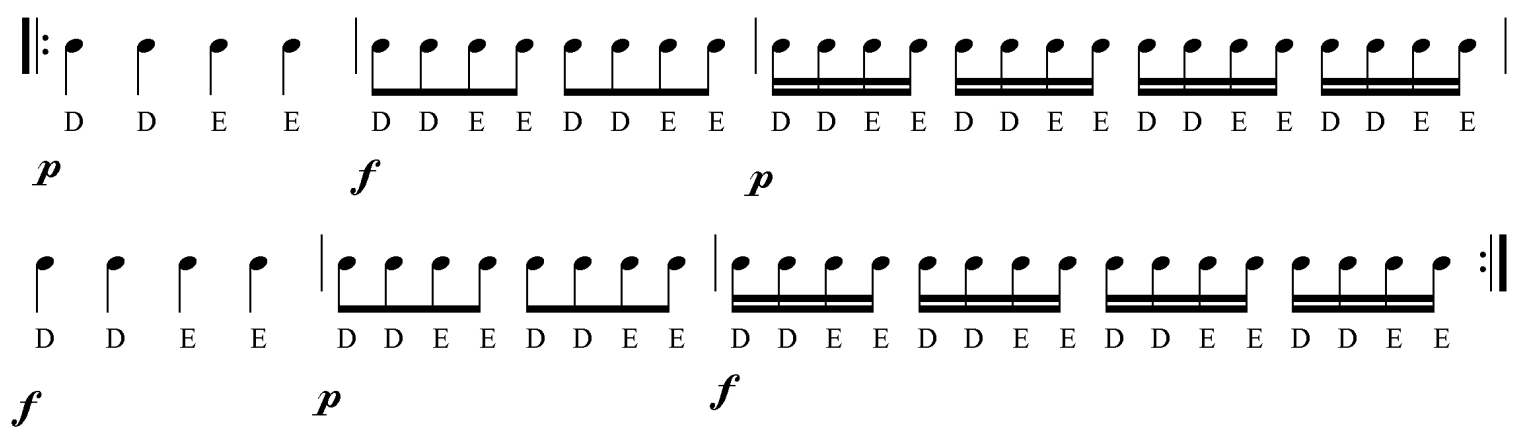

Com o pandeiro, a partir do mesmo ritmo praticado na unidade anterior, um novo exercício adiciona o tapa $(\mathrm{t})$, tocando com a mão aberta no centro da pele, produzindo um som curto e seco. A seguinte notação foi utilizada: 


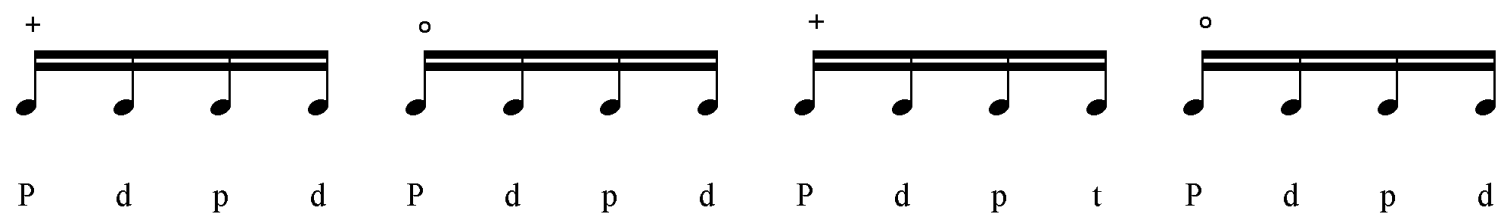

No ambiente virtual, novamente os alunos deveriam enviar dois vídeos, demonstrando seu desenvolvimento com as práticas colocadas acima. Além disso, a seguinte instrução foi postada na forma de fórum: "elabore a proposta de uma atividade educacional utilizando percussão, indicando quais conceitos musicais estão sendo trabalhados e com quais disciplinas de estudo essa atividade se relaciona. Se possível, procure incluir elementos de improvisação ou criação musical". As atividades propostas ficaram acessíveis a todos, permanecendo abertas a críticas e sugestões.

Para relacionar os conteúdos estudados na percussão com a disciplina "Introdução aos métodos, técnicas e fundamentos em educação musical", também houve uma indicação de leitura como estudo complementar, focando a proposta educativa de Carl Orff, na qual instrumentos de percussão são usados como ferramentas importantes na educação musical. Para tanto, foi usado um link do site http://books.google.com, levando à visualização do livro De Tramas e Fios, de Marisa Trench Fonterrada, que trata sobre esse assunto.

Por último, diversos vídeos de Airto Moreira e Naná Vasconcelos foram indicados no YouTube, servindo como exemplos de percussionistas improvisando de forma muito musical.

\subsubsection{Unidade 5: Peça para caixa clara e baião no pandeiro}

- Texto básico para estudos:

A unidade 5 propõe um fechamento ao que foi visto na disciplina. Concluindo os trabalhos com baquetas, os exercícios das unidades anteriores foram combinados para tocar uma peça para caixa clara (ver a página 153), utilizando os rudimentos em uma realização musical. Rudimentos são como palavras, pois quando são combinados formam frases, expondo idéias de forma suave ou agressiva, fazendo perguntas e dando respostas, buscando um discurso musical. 
Durante as 8 semanas da disciplina, foram estudadas algumas palavras que possibilitam construir frases simples, como aquelas da peça que foi apresentada. Esse vocabulário é pequeno, se comparado ao número de rudimentos que existem, e é importante compreender a dimensão do que foi realizado dentro de uma vasta realidade de estilos, instrumentos e técnicas da percussão.

O texto dessa unidade, como está transcrito a seguir, destacou diversos aspectos que devem ser observados pelo aluno na execução da peça para caixa clara:

- A indicação de mãos para cada toque deve ser respeitada. Sem isso, o exercício não tem sentido. Portanto, sempre que uma nota for marcada com a letra (d), deverá ser tocada com a direita; quando a marcação for (e), a esquerda entra em ação.

- As dinâmicas indicadas valem até que outra marcação apareça. Ou seja, como a peça começa com (f), todas as notas deve ser tocadas forte até que a indicação (p) apareça. A partir daquele ponto, todas as notas devem ser tocadas piano, com exceção daquelas marcadas com acento (>). As notas acentuadas deverão ser tocadas forte e bem destacadas das outras, que continuam piano. Isso irá mudar somente quando outra indicação (f) surgir, no terceiro compasso.

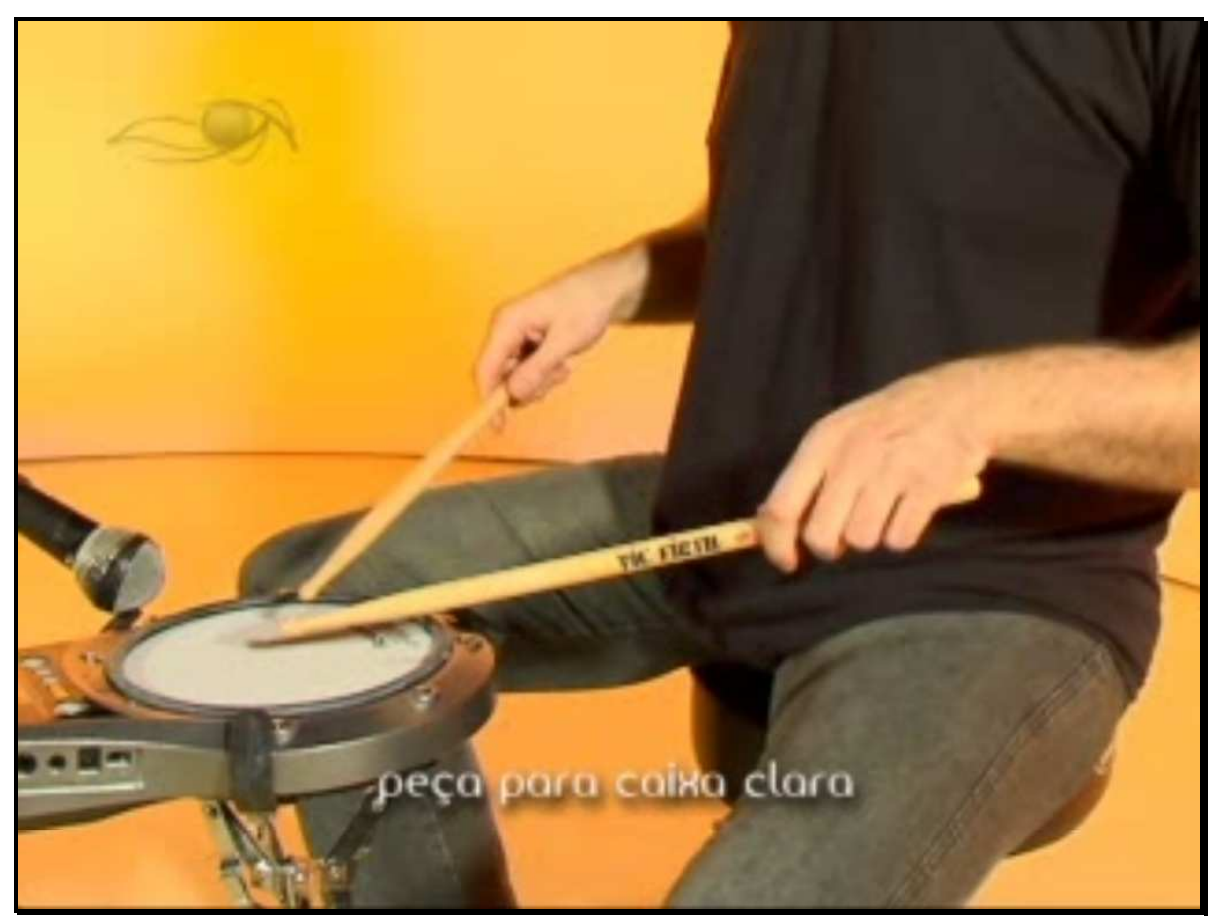

Figura 13: vídeo demonstrando a peça para caixa clara 
- No final, há uma indicação de crescendo (_ _ Esse trecho será um desafio, pois cada toque deverá ser gradualmente mais forte do que o anterior. Perceba que o início da frase deve ser tocado piano e o final é forte. Tente fazer a transição entre esses dois pontos da maneira mais uniforme que for possível.

- É importante que o tempo seja mantido constante na totalidade da peça. Não toque mais rápido quando tiver que tocar forte, e nem mais lento nos trechos marcados piano. Se possível, pratique sempre com o auxílio de um metrônomo.

Em seguida, um segundo ritmo no pandeiro foi estudado: o baião. Vários outros ritmos também podem ser tocados no instrumento, incluindo funk, maracatu e afoxé, usando diferentes acentuações e combinações dos movimentos que foram estudados. Nos livros da bibliografia indicada para a disciplina, há exercícios para desenvolver esses ritmos, e nos vídeos indicados ao final da unidade é possível constatar a complexidade da linguagem moderna do pandeiro, abrindo um vasto campo de possibilidades a explorar. $\mathrm{O}$ texto procurou estimular a continuidade dos estudos, que durante as 8 semanas da disciplina apresentaram apenas o início do que pode ser uma longa jornada.

- Atividades de aplicação, prática e avaliação

Pela última vez, os alunos deveriam enviar seus vídeos demonstrando suas práticas com baquetas e com o pandeiro. A peça para caixa clara, transcrita mais adiante, exigiu controle sobre a colocação dos toques, sobre as dinâmicas e os acentos. Com o pandeiro, foram colocadas duas etapas para caracterizar uma célula rítmica que é típica do baião. Primeiro, foi adicionado um acento na $4^{\mathrm{a}}$ nota do exercício apresentado na unidade 2 , mantendo a mão que toca o pandeiro semi curvada e alternando toques do punho com toques de ponta dos dedos, enquanto a mão que segura o instrumento acompanha esses movimentos com leves torções do pulso:

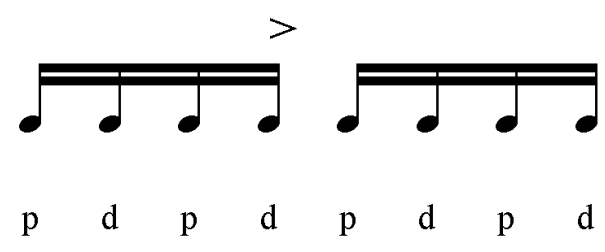


$\mathrm{Na}$ seqüência, foi acrescentado um toque aberto com o polegar, na primeira nota do exercício.

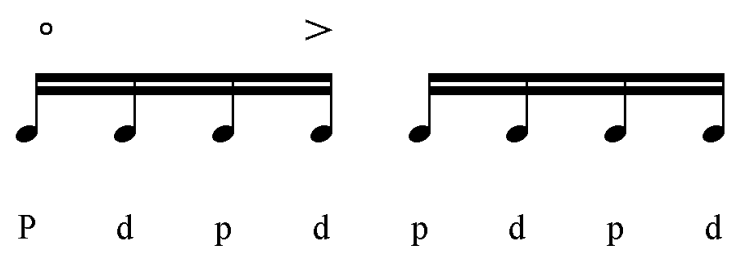

Após conseguir tocar o baião no pandeiro, foi sugerido ao aluno cantar a música "Asa Branca" enquanto praticava, buscando firmeza na relação entre voz e mãos. Vídeos do percussionista Marcos Suzano foram indicados no YouTube, misturando vários ritmos e demonstrando as complexas possibilidades sonoras do instrumento. Conforme o que é discutido, esses ritmos não devem ser encarados como objetivos de curto prazo.

Como estudo complementar, um vídeo mostrou um ritmo de baião no triângulo, outro instrumento leve e compacto, bastante útil para atividades educacionais. A seguinte notação foi usada, em que o sinal (+) indica som fechado e o sinal (o) indica som aberto:

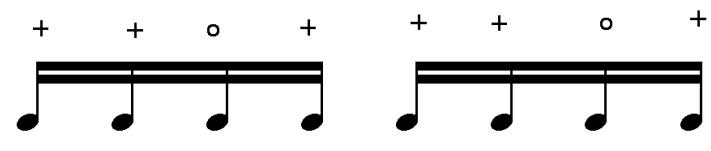

Concluindo a disciplina, foi proposta uma discussão no fórum, tendo como tema o estudo de instrumentos musicais por meio de um ambiente virtual, indicando pontos positivos e negativos na experiência que estava se encerrando. Para embasar o debate, foi indicada a leitura da introdução do livro Auto-aprendizagem Musical: Alternativas Tecnológicas, que expõe uma pesquisa sobre o uso de mediações tecnológicas para a aprendizagem de percussão. Esse trabalho é da mesma autoria do pesquisador dessa tese de doutorado, e foi visualizado por meio de um link no site http://books.google.com. 
Peça para caixa clara

Daniel Gohn

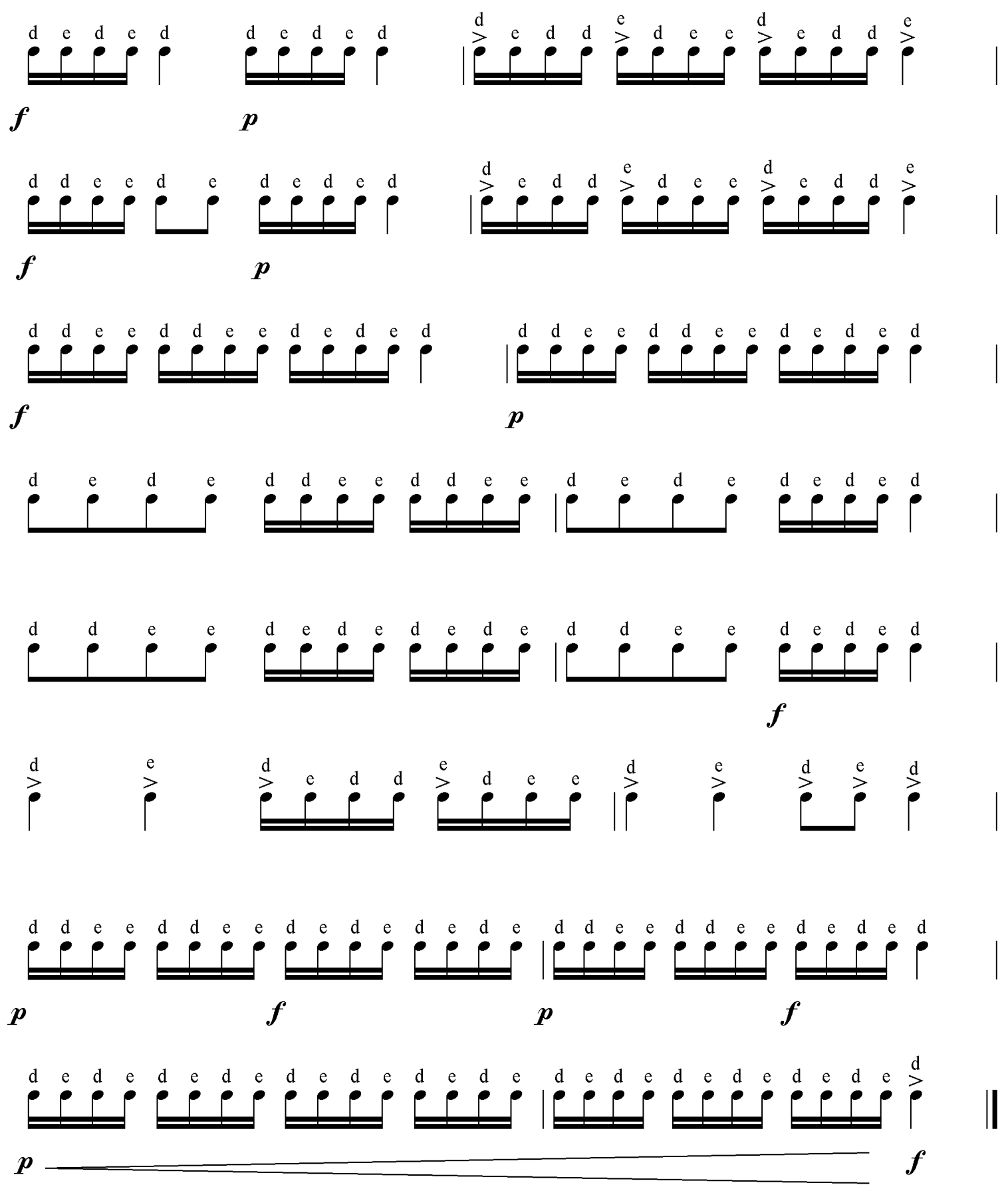


- Avaliação presencial

O último encontro presencial da disciplina, após a oitava semana de estudos, foi para a avaliação presencial. Os outros encontros ocorreram durante a segunda e a quinta semana, e serviram para que os alunos resolvessem dúvidas, trocassem impressões com seus colegas e os mais experientes prestassem auxílio aos iniciantes. No encerramento das atividades, para a avaliação final, cada aluno deveria demonstrar aos tutores presenciais o samba no pandeiro e a peça para caixa clara. Instruções para a organização dessa prova foram passadas conforme consta no anexo $\mathrm{C}$, assim como os critérios de avaliação, incluindo andamento (o aluno conseguiu manter o andamento quando tocou?), acentos (o aluno teve consistência nas dinâmicas?), desenvoltura (os ritmos tocados foram bem articulados?), e avanços (o aluno se desenvolveu durante o semestre?). Além das notas, os tutores inseriram no Moodle comentários para cada aluno, justificando suas avaliações e indicando pontos a melhorar.

\subsection{O que aconteceu?}

Alguns acontecimentos registrados no primeiro oferecimento da Percussão, no curso a distância de Licenciatura em Educação Musical da UAB - UFSCar, entre março e abril de 2009, representam o impacto inicial gerado pela disciplina. Análises contínuas dos resultados, envolvendo mais alunos em outras oportunidades, serão necessárias para direcionar futuras mudanças nos conteúdos, nas formas de apresentação e de interação, e em outros aspectos que venham se mostrar pertinentes. Dentro do escopo dessa tese, a seguir são apresentados os resultados iniciais obtidos.

Os alunos participantes nesse primeiro oferecimento tinham apoio nos pólos em Barretos, Jales e Osasco. Conforme mostrado no anexo A, a disciplina fez parte do módulo 3A, no quarto semestre de estudos. Portanto, os princípios do funcionamento do curso já eram conhecidos e algumas das dificuldades encontradas pelos estudantes possivelmente já tinham sido superadas. Tratava-se de um grupo maduro, em que aproximadamente dois terços têm mais de 30 anos de 
idade $^{74}$. Tal perfil se mostrou bastante favorável ao sistema de educação a distância, pois contava com uma maioria experiente e propícia a reflexões e aos estudos autônomos.

As observações colocadas a seguir são reflexos de opiniões individuais de alguns alunos, expressadas nos fóruns ou diretamente ao professor por e-mail; de conversas com os tutores, tanto os virtuais como os presenciais; e das conclusões do próprio pesquisador, a partir de resultados nas atividades realizadas.

- Críticas e elogios

Críticas e elogios marcaram as reações iniciais dos alunos na primeira oferta da Percussão. Durante os trabalhos, alguns alunos externaram uma grande satisfação em ter essa disciplina incluída no curso, fato que não estava previsto no cronograma curricular inicialmente divulgado. Entre os pontos positivos destacados, pode-se citar a oportunidade de uma vivência rítmica e instrumental, principalmente com o uso do pandeiro; os vários usos de instrumentos de percussão na sala de aula e as atenções que eles atraem em crianças; a exploração de objetos sonoros a partir do aprendizado da percussão; o aspecto lúdico que o estudo instrumental traz ao curso; a possibilidade de participações musicais de crianças desde o primeiro contato com os instrumentos; avanços na compreensão de ritmos brasileiros que serão estudados, como o samba e o baião; o desenvolvimento da coordenação motora; e uma valorização da cultura musical brasileira, tão atrelada aos ritmos e aos instrumentos de percussão.

O material didático foi bastante elogiado, principalmente os vídeos que demonstravam os exercícios. Nos relatos das práticas iniciais, realizados ao final da unidade 2, foi mencionada a complexidade gradual das atividades, com etapas que começavam simples e criavam desafios maiores aos poucos. A possibilidade de repetir os vídeos várias vezes, tentando emular os movimentos seguidamente, também foi colocada como um agente facilitador no aprendizado. As reclamações registradas nessas práticas iniciais estavam relacionadas a problemas comuns para os estudantes de percussão: conseguir tocar nos andamentos indicados, a maior dificuldade em tocar com a mão esquerda (para os destros), e as dores musculares resultantes dos estudos.

\footnotetext{
${ }^{74}$ Um questionário preparado por Santiago (2009) foi respondido por 53 dos 100 alunos de Educação Musical nos pólos de Barretos, Jales e Osasco. Desse total de 100 indivíduos, 87 estavam matriculados na disciplina Percussão. As faixas etárias pesquisadas revelaram apenas 1 aluno com até 19 anos, 9 entre 20 e 24 anos, 3 entre 25 e 29 anos, 9 entre 30 e 34 anos, 9 entre 35 e 39 anos, 11 entre 40 e 44 anos, 4 entre 45 e 49 anos, e 7 entre 50 e 59 anos.
} 
As principais críticas recebidas, vindas de vários alunos, foram ocasionadas pelos encontros presenciais. A mesma questão foi reportada por Souza (2003) em sua tese, na qual professores em capacitação a distância reclamaram da brevidade e da pouca quantidade de momentos presenciais. No caso da disciplina Percussão, a queixa foi causada pela ausência do professor em todos os encontros, o que levou a situações diferentes em cada pólo, dependendo de alunos com mais experiência em percussão e dos tutores presenciais. Embora as atividades de cada aula presencial tenham sido organizadas e passadas aos tutores, houve a falta de uma referência mais consistente, que desse um feedback imediato e específico para cada aluno. De certa forma, a tarefa de envio de vídeos, a partir da unidade 3, com os subsequientes comentários dos tutores virtuais, serviu para amenizar esse problema, mas apenas parcialmente. As tentativas de emular movimentos do professor, as formas de segurar as baquetas, a pressão exercida sobre elas em cada toque, diferentes maneiras de tocar o pandeiro, entre outras questões, causaram dúvidas que seriam resolvidas mais facilmente de forma presencial. A solução mais efetiva é a organização de uma visita do professor aos pólos, o que não ocorreu no primeiro oferecimento da disciplina.

- Falhas na organização

A falha mais evidente na organização da disciplina ocorreu no planejamento dos encontros presenciais, que poderiam ter sido mais aproveitados. Os relatos dos tutores presenciais apontam para trocas produtivas de experiências entre os alunos, como estava programado, mas também para a existência de dois tipos de dúvidas que não foram sanadas durante os encontros. Primeiramente, como observado no tópico acima, muitos alunos precisavam de orientações sobre os exercícios que estavam praticando, e não havia pessoal capacitado para isso no local. Questões relacionadas a dores musculares provocaram inquietações, assim como perguntas sobre variações dos procedimentos apresentados nos vídeos e sobre posturas alternativas para praticar os exercícios. Além da presença do professor, um maior detalhamento das atividades pode contribuir para um melhor uso do tempo disponível nos pólos.

O segundo tipo de dúvida estava relacionado com os conteúdos que fariam parte da disciplina. Houve um atraso na entrega do material impresso, contendo todas as unidades, que 
deveria chegar a tutores e alunos logo no começo do semestre. As versões online desse material, no Moodle, eram disponibilizadas somente no início do período reservado a cada unidade, colocando os tutores presenciais na mesma situação dos alunos, sem saber o que seria estudado nas semanas seguintes. Essa falha ocorreu pelo desconhecimento, por parte do professor, do fato de que seria o responsável por "abrir" cada unidade para os tutores.

Duas medidas foram tomadas para corrigir o erro. Todas as unidades foram simultaneamente disponibilizadas aos tutores presenciais no Moodle, assegurando a eles uma visão completa dos conteúdos da disciplina, e DVDs com todos os vídeos foram produzidos e enviados aos pólos, para que eventuais dificuldades de acesso a Internet fossem superadas. Dessa forma, os tutores teriam condições para responder diretamente pela disciplina, resolvendo dúvidas com o professor antecipadamente e se sentindo responsáveis pelos materiais didáticos preparados.

- Problemas musculares

Como já era previsto, diversos alunos comunicaram problemas com dores musculares durante a disciplina. O material didático, conforme foi apresentado anteriormente, abordou essa questão e, além de advertências sobre os riscos envolvidos, ressaltou a importância de alongamentos antes das sessões de práticas. A questão surgiu principalmente com o pandeiro, pois a movimentação constante tanto da mão que segura o instrumento, carregando o seu peso e realizando uma torção repetida, como da outra mão, que deve atacar a pele, representa uma grande exigência física para um iniciante. A maioria das reclamações recebidas pode ser considerada dentro da normalidade, em que a musculatura dos pulsos é fortalecida após algumas semanas de estudo e os períodos de prática podem ser gradativamente prolongados.

No entanto, alguns alunos demandaram atenções especiais, agravadas pela impossibilidade de uma análise presencial do professor. Foram reportados casos de indivíduos com problemas de artrite, tendinite, e de uma cirurgia mal sucedida no punho esquerdo. Segundo as comunicações com esses alunos, dificuldades já eram enfrentadas na performance com outros instrumentos, principalmente o piano, antes do início da disciplina. Porém, sabendo que o pandeiro exige não somente movimentos repetitivos, mas também impactos físicos constantes, 
além do fato de que o instrumentista suporta o peso do instrumento enquanto está tocando, a cautela foi dobrada. Não se poderia permitir que um problema pré-existente passasse despercebido. Portanto, a recomendação de consultar um médico especialista, capacitado para avaliar a situação desses estudantes, foi acompanhada da garantia que os alunos não seriam prejudicados em suas notas se ficassem impossibilitados de cumprir tarefas do curso.

- Assuntos abordados nos fóruns

Vários foram os assuntos em discussão nos fóruns, extrapolando as propostas iniciais e colocando em circulação outros temas de interesse para professores de música. Alguns desses assuntos tratavam de percussão sem instrumentos tradicionais, com o uso de objetos sonoros diversos, como sucata, utensílios de cozinha e bolas de basquete, ou abordavam a percussão corporal. Usos alternativos de instrumentos tradicionais foram mencionados, quando um vídeo do violonista Andy McKee foi postado, mostrando o músico tocando melodia e harmonia no violão enquanto percutia o instrumento. $\mathrm{O}$ resultado soava similar a um bongô, que acompanhava as linhas rítmicas criadas com as cordas.

Instrumentos que usualmente não estão no foco das atenções no dia-a-dia foram objetos de análise, por exemplo, em um vídeo que mostra um solo de cuíca junto ao Trio Mocotó. O mesmo aconteceu com o berimbau em vídeos de Naná Vasconcelos, amplamente elogiado por alunos que presenciaram suas performances. Hermeto Pascoal foi outro nome bastante citado, por utilizar diversos objetos como instrumentos em sua música, como panelas e brinquedos de plástico, além de formas criativas para explorar os sons percussivos de seu próprio corpo. A prática do Beat Box, na qual indivíduos reproduzem a sonoridade de diversos instrumentos com a boca, foi observada e comentada, como também a Vienna Vegetable Orchestra, uma orquestra austríaca que utiliza como instrumentos musicais somente legumes e vegetais adaptados.

As realidades regionais do Brasil foram colocadas em pauta ao se discutirem vários projetos sociais de organizações não governamentais (ONGs) que envolvem trabalhos com percussão. Foram citados como exemplos os projetos Batucar, de Brasília; Calo na Mão, em escolas públicas de São Paulo, também com oficinas de construção de instrumentos; Meninos do Morumbi, que obteve reconhecimento internacional e patrocínio de grandes empresas; Lata Viva, 
em Minas Gerais; e Sucantando, em São Bernardo do Campo, que trabalha com a reciclagem de sucata para criar instrumentos musicais.

Outras discussões surgiram a partir de trabalhos desenvolvidos pelos alunos em suas comunidades, em orquestras locais ou escolas onde já atuam como professores. Casos que lidam com alunos especiais chamaram a atenção, como um deficiente auditivo que toca sentindo a vibração dos instrumentos de percussão. Embora os participantes já se conhecessem dos encontros presenciais, muitas de suas experiências só eram expostas quando um tema colocado em debate era ligado àquela situação vivenciada anteriormente.

Os exemplos acima estão entre vários outros que surgiram durante a disciplina. A maioria apenas recebeu o reconhecimento como "interessante" ou "útil", mas alguns suscitaram interações mais prolongadas. De qualquer forma, os assuntos foram levantados e tornados públicos, conscientizando os alunos sobre diversos elementos pertinentes ao estudo da percussão.

- Flexibilização dos períodos de entrega de tarefas

As datas limite para a realização de cada uma das tarefas da Percussão, como em todas as outras disciplinas da Licenciatura em Educação Musical da UAB - UFSCar, estavam definidas antes do início do semestre. Entretanto, muitos alunos não conseguiram sempre cumprir as atividades dentro dos prazos. Tal constatação revelou um problema: diferentemente do que havia sido anunciado pelos tutores presenciais, muitos alunos não dominavam o processo de produção e envio de vídeos. Durante a preparação dos conteúdos, uma investigação com os tutores confirmou que outras disciplinas já tinham exigido a capacidade de lidar com o registro de imagens, e portanto seria simples usar esse mecanismo como meio de avaliação e feedback. Não foi o que aconteceu. Por este motivo, muitos estudantes tiveram dificuldades para entregar suas tarefas a partir da unidade 3, principalmente com o tamanho dos arquivos, que não poderia ser superior a $20 \mathrm{Mb}$.

A indicação de websites na Internet, com diretrizes para facilitar a edição de vídeos, a conversão de formatos e a diminuição de arquivos, foi o primeiro passo para tratar a questão. Os tutores virtuais também foram de extrema importância, auxiliando alunos em suas necessidades específicas. Mesmo assim, alguns indivíduos comunicaram problemas técnicos ou falta de 
equipamentos em suas residências ${ }^{75}$. Diante dessa situação, os períodos para a entrega das tarefas foram ampliados em diversas ocasiões. O mesmo cenário ocorreu nas formações de professores organizadas por Souza (2003) e Henderson Filho (2007), em suas pesquisas de doutorado, que também flexibilizaram os prazos finais programados para suas atividades. Como aspecto a melhorar na disciplina Percussão, um tutorial será preparado para instruir os alunos nos procedimentos envolvidos na produção e na edição de vídeos.

- Dúvidas de tutores nas avaliações

O processo de avaliação despertou dúvidas para os tutores. A mistura de alunos experientes, que já tocavam instrumentos de percussão antes de iniciar a disciplina, e outros iniciantes, que estavam tendo seus primeiros contatos com as práticas percussivas, resultou em limiares de exigência diferenciados para cada um desses grupos. Tais desníveis eram evidentes tanto no discurso dos alunos, no relato de suas práticas iniciais, quanto nos vídeos enviados, que mostraram suas facilidades e dificuldades. A situação gerou algumas incertezas e diversas consultas dos tutores ao professor, que foram tratadas caso a caso, considerando as experiências anteriores de cada aluno. Nesse contexto, existe o risco de que a avaliação se torne subjetiva, sem acompanhar os objetivos inicialmente traçados.

Ao estabelecer objetivos, o professor sugere um conjunto de saberes considerados necessários para que os alunos se desenvolvam no âmbito daquela disciplina. Mas esse conjunto perde seu caráter necessário ou sua relevância para o desenvolvimento dos alunos quando é desconsiderado durante a avaliação, a qual se torna algo "muito pessoal" (DEL BEN, 2001: 254).

Em sua pesquisa de doutorado, Del Ben (2001) analisou práticas pedagógico-musicais de professoras de música do ensino fundamental, constatando que, embora elas definissem objetivos e ações específicas para suas atividades nas aulas, isso não era considerado como possível dimensão a utilizar na avaliação dos alunos. Dar notas a um aluno era tido como algo "muito pessoal”, o que pode dificultar a demonstração da relevância do estudo musical para a

\footnotetext{
${ }^{75}$ Havia equipamentos disponíveis nos pólos, mas como os alunos não os freqüentam diariamente, a falta de uma câmera de vídeo representou um entrave para vários estudantes. O sistema de gravação de vídeo de celulares foi usado em alguns casos, com resultados pouco satisfatórios, pela baixa qualidade da captação de som e imagem.
} 
comunidade escolar e para a sociedade em geral. Diante desse cenário, surge a seguinte indagação: "qual o sentido de estabelecer metas, objetivos e conteúdos de ensino relativos à prática musical dos alunos se eles não são contemplados na avaliação da aprendizagem?” (DEL BEN, 2001: 255).

Para não fugir dos objetivos estabelecidos e para minimizar o caráter subjetivo da avaliação na disciplina Percussão, foi adotado o critério "avanço", indicando que cada aluno partiu de um início diferente e se desenvolveu até determinado ponto. Com esse critério, a aprendizagem é reconhecida e o esforço individual é valorizado, apesar da grande discrepância entre os alunos nas provas finais. Seria impossível manter a mesma exigência para todos, como a execução de um solo de caixa com perfeição, com uma determinada marcação única no metrônomo. Portanto, na avaliação final, os alunos iniciantes puderam tocar a "peça para caixa clara" em andamentos mais lentos, seguindo os critérios dos tutores presenciais. Nos vídeos avaliados pelos tutores virtuais, a exigência de precisão dos acentos e dinâmicas nos exercícios também foi "adaptada".

Ao término dos trabalhos, após conversas via e-mail e Skype, os tutores se sentiram mais seguros em assinalar suas notas finais. Com novas ofertas da disciplina, a expectativa é de que a experiência acumulada com várias turmas dê mais uniformidade e consistência ao processo avaliativo. Estando os objetivos e conteúdos definidos, conforme foi exposto nesta pesquisa, é possível dimensionar essa avaliação, mas sem privilegiar aqueles que já estudaram percussão anteriormente.

- Resultados das performances

O elemento mais importante da disciplina Percussão é o ensino de instrumentos musicais, propondo aos alunos uma série de práticas regulares e sistematizadas. Como resultado desse processo, depois das 8 semanas de estudos, em sua maioria, os estudantes conseguiram tocar os ritmos propostos com o pandeiro e demonstraram uma boa desenvoltura com as baquetas. A qualidade das performances deve ser destacada, com a obtenção de boas sonoridades nos instrumentos e andamentos consistentes nos exercícios.

Como era esperado, houve uma margem considerável entre os resultados de alunos 
iniciantes e daqueles que já tinham experiência com percussão. No entanto, foi comprovado que todos os alunos aprovados na disciplina ${ }^{76}$ tornaram-se aptos a usar os instrumentos estudados como ferramentas para atividades educacionais. Com o pandeiro, poderão tocar ritmos básicos de samba e de baião; com as baquetas, poderão tocar diversos instrumentos com precisão e segurança.

Muitos alunos apresentaram limitações quanto a andamentos rápidos e variações dos exercícios praticados. Por exemplo, o uso do tapa no ritmo de samba foi visto de uma forma, mas pode ocorrer de outras, em combinação com toques que não foram estudados. O aprofundamento com essas variações e a capacidade para tocar em andamentos mais rápidos demandam períodos de prática mais extensos, ficando como opção para aqueles interessados em continuar seus estudos de percussão após o término da disciplina. Mesmo com essas limitações, os conhecimentos procedimentais desenvolvidos serão bastante significativos para os professores de música, por criar alternativas para suas futuras atuações docentes.

Portanto, pode-se afirmar que a hipótese colocada no primeiro capítulo dessa tese foi confirmada: o ensino a distância foi utilizado eficientemente como meio para a disciplina Percussão, contribuindo para a formação de educadores musicais.

\subsection{O que vai acontecer?}

A partir dos acontecimentos descritos acima, começou uma lapidação da proposta para a disciplina Percussão. Assim como ocorre na educação presencial, a experiência com cada turma gera reformulações nas formas de lidar com determinados conteúdos. A diferença na EAD está no fato de que, na realidade da UAB - UFSCar, os custos e as logísticas para modificar constantemente os materiais impressos são proibitivos, e essa restrição petrifica parcialmente a ação dos professores. Por outro lado, o uso de ambientes virtuais de aprendizagem possibilita uma grande flexibilidade, inclusive para ajustes durante o semestre letivo. Abaixo, são destacados alguns pontos que serão modificados na disciplina Percussão.

\footnotetext{
${ }^{76}$ Dos 87 alunos inicialmente matriculados na primeira oferta, 62 concluíram a disciplina Percussão e foram aprovados, representando um índice de $71,2 \%$ do total. Dos outros 25 alunos, 5 nem começaram os estudos e 20 participaram das primeiras unidades, mas desistiram ao longo do semestre. A disciplina Percussão é obrigatória e deve ser cursada por todos, com duas chances para aprovação. Após duas reprovações em qualquer uma das disciplinas, o aluno é desligado do curso da UAB - UFSCar.
} 
- Encontros presenciais

As críticas sobre os encontros presenciais podem ser tratadas, a distância, com duas ações: 1) uma melhor estruturação das atividades programadas; e 2) participações do professor. A programação das atividades deve sempre considerar os tutores presenciais como iniciantes na percussão (embora alguns tenham experiências anteriores significativas), detalhando as propostas minuciosamente. Suas atuações nos momentos presenciais devem ser a de coordenadores de atividades, gerenciando o tempo disponível para que seja bem aproveitado. Para responder perguntas específicas da percussão, a contribuição de alunos percussionistas é bem-vinda, mas obviamente não pode ser pré-requisito para a existência da disciplina. Portanto, a intervenção do professor de forma síncrona é importante, especialmente quando todos os alunos estão reunidos e questões de interesse geral podem surgir.

Um problema mencionado de forma recorrente pelas secretárias do curso de Licenciatura em Educação Musical da UAB - UFSCar é o "ciúme” que existe entre os pólos. Quando um pólo recebe tratamento diferenciado, os outros imediatamente se manifestam e exigem igualdade. Assim como Cajazeira (2004) descobriu no curso a distância que ministrou para músicos de uma orquestra filarmônica, confirmou-se que os encontros presenciais são essenciais para manter a motivação dos estudantes. Há uma preocupação da coordenação da UAB - UFSCar em manter o estímulo e a sensação de que toda a atenção e cuidados possíveis estão direcionados para todos os alunos. Por essa razão, idealmente, o planejamento de visitas de um professor deve incluir todos os pólos em que sua disciplina é ofertada. Por motivos de ordem organizacional, há dificuldades em assegurar que isso aconteça em todas as disciplinas. Ao menos para a Percussão, nos semestres seguintes, deverá ocorrer uma visita do professor a cada pólo.

Além disso, uma alternativa tecnológica se apresenta como maneira de lidar com a questão: a videoconferência. A UAB dispõe de pessoal e equipamentos para videoconferências. Embora entre esses equipamentos não existam microfones especiais para a captação sonora de boa qualidade, o sistema possibilita que, se o professor fornecê-los, seja viável a transmissão de som e imagem de demonstrações com instrumentos musicais. Dessa forma, mesmo sem estar fisicamente nos pólos, nos encontros presenciais dos próximos oferecimentos da disciplina Percussão, poderá acontecer uma participação síncrona do professor. 
- Modificações nos conteúdos

Os conteúdos postados no ambiente Moodle devem ser constantemente revisados, pois são usados muitos links para websites e vídeos de serviços como o YouTube, que podem ser retirados do acesso público sem notificação prévia. Também é possível usar exemplos mais atuais e relevantes do que os inicialmente escolhidos, incluindo itens do crescente acervo de recursos educacionais abertos na Internet. Além disso, as contribuições de um grupo de alunos podem servir para turmas posteriores, ficando a cargo do professor a tarefa de inserção. Por exemplo, nos fóruns de discussão desse primeiro oferecimento da disciplina, foram citados diversos projetos sociais que trabalham com percussão, alguns deles pouco divulgados em jornais e demais veículos da comunicação de massa. Sendo esse assunto de grande valor para a formação do educador musical ${ }^{77}$, a única maneira de garantir que todas as turmas tenham acesso aos vídeos e websites indicados é torná-los parte dos conteúdos regulares da disciplina.

Outros materiais que devem ser aprimorados regularmente são os tutoriais para auxiliar alunos a lidar com a tecnologia. Essa questão é compartilhada com outras disciplinas, pois muitas poderão exigir conhecimentos para a produção de áudio e vídeo. Com o surgimento regular de novos softwares, é importante manter tutoriais atualizados e simplificados, na medida em que as perguntas apresentadas pelos estudantes revelem suas dificuldades para gravar, editar, converter formatos e enviar arquivos de som e imagem.

- Maior integração da disciplina no curso

Os trabalhos da disciplina Percussão ocorreram na seguinte situação: professor em São Paulo, coordenação do curso e equipes de elaboração e produção do material pedagógico em São Carlos, tutores virtuais em cidades diferentes, tutores presenciais nas cidades dos pólos, e alunos espalhados em regiões adjacentes a esses pólos. Essas distâncias criaram dificuldades que já foram discutidas nesta tese, envolvendo professor, tutores e alunos. Além dessas, outros desafios

\footnotetext{
${ }^{77}$ A importância da conscientização social na formação do educador foi bastante discutida com a coordenação do curso de Licenciatura em Educação Musical da UAB - UFSCar. Os planejamentos para um segundo módulo da disciplina (que será chamado de Percussão II), optativo, incluem materiais sobre projetos de Organizações NãoGovernamentais. No entanto, após perceber o efeito frutífero dos exemplos mencionados na Percussão, apresentada nesse trabalho, foi decidido inserir esses conteúdos também nos próximos oferecimentos do primeiro módulo.
} 
surgem na relação entre o grupo de docentes e a coordenação do curso, para que exista uma integração entre os conteúdos e as metodologias de todas as disciplinas.

A percussão poderá ser melhor aproveitada como elemento útil em outras disciplinas, quanto maior for a comunicação entre os professores. Conhecer o trabalho dos outros sem dúvida ajudará a moldar o aspecto pedagógico coletivo do curso, como usualmente (ou idealmente) deve ocorrer em qualquer programa educacional. Mas, na experiência com percussão na UAB UFSCar, dois pontos dificultaram que as comunicações fossem ideais.

Primeiramente, a elaboração de uma disciplina deve acontecer antes do início das aulas, num período em que encontros com outros professores são raros. Todos estão envolvidos com atividades diversas, muitas das quais relacionadas às aulas presenciais de outros $\operatorname{cursos}^{78}$ ou à preparação dos conteúdos de disciplinas para o próximo semestre. A disponibilização dos materiais de disciplinas em andamento, feita pela coordenação do curso, durante a etapa da preparação pedagógica para o ambiente Moodle, colaborou bastante para uma visão geral do currículo. Mas, para o desenvolvimento dessa questão, conversas diretas com os professores serão importantes e, dentro das possibilidades, certamente irão ocorrer ao longo do tempo.

O segundo ponto desafiador é a falta de convívio social com os outros docentes. Os contatos entre professores que trabalham em uma mesma cidade ultrapassam o horário das reuniões oficiais, se estendendo para conversas informais, nas quais podem surgir idéias, propostas e esclarecimentos. As comunicações com aqueles em cidades diferentes, pelas limitações de tempo, normalmente restritos e muitas vezes em situações mais formais, podem fazer com que um entrosamento demore mais a surgir.

Para que isso aconteça, além de reuniões pedagógicas regulares, existirão oportunidades em encontros presenciais de que também fazem parte tutores e os alunos de todos os pólos. Um evento que criou essa situação foi o $1^{\circ}$ Encontro de Alunos da UAB - UFSCar, realizado em Junho de 2009, com palestras, mesas redondas e mini-cursos. Uma oficina de percussão foi oferecida nessa ocasião, fazendo referência à disciplina do curso a distância e tendo como participantes alunos que já a tinham cursado, outros que a iriam cursar, e alunos do curso presencial da UFSCar.

\footnotetext{
${ }^{78}$ Muitos professores do curso da UAB - UFSCar também lecionam no curso presencial de Licenciatura em Educação Musical da UFSCar. Assim, dividem seus esforços entre dois universos, o que exige boa organização e esforços dobrados.
} 
A expectativa futura é de que, havendo uma maior integração da disciplina Percussão no curso, sejam criados outros módulos de disciplinas para o estudo da percussão, opcionais, com conteúdos mais específicos para aprendizes interessados em aprofundar seus conhecimentos, dando continuidade aos avanços da educação musical a distância na área de performance. 


\section{Conclusão}

Faremos com as tecnologias mais avançadas o mesmo que fazemos conosco, com os outros, com a vida. Se somos pessoas abertas, iremos utilizá-las para nos comunicarmos mais, para interagirmos melhor. Se somos pessoas fechadas, desconfiadas, utilizaremos as tecnologias de forma defensiva, superficial. Se somos pessoas autoritárias, utilizaremos as tecnologias para controlar, para aumentar nosso poder. $\mathrm{O}$ poder de interação não está fundamentalmente nas tecnologias mas nas nossas mentes (MORAN, 2002: 63).

Embora a introdução dessa tese tenha mencionado obras de ficção científica, os capítulos posteriores comprovaram uma realidade bastante concreta no Brasil dos dias atuais. Com um leque de tecnologias da comunicação musical indo de partituras às redes eletrônicas, a educação musical a distância procura seus caminhos, alçados com experiências em cursos formais e inovações em softwares e recursos da Internet. A constatação de que os avanços tecnológicos acontecem de forma irreversível, cada vez mais rápido, leva a conclusão de que a área está em uma fase transitória, passando da desconfiança total para uma aceitação mais ampla, mas que ainda existem barreiras e complicações que merecem investigação e exigem cautela.

Se as previsões feitas por escritores de ficção científica estiverem corretas, como ocorreu nos casos citados no início, no futuro haverá aulas a distância com o uso de holografias, ou seja, projeções tridimensionais que irão simular a presença física real de professor e aluno em um mesmo espaço. A transmissão de som e imagem, com conexões medidas em Gigabites por segundo, como já existe em algumas redes no Canadá ${ }^{79}$, proporcionará uma escuta musical refinada e detalhes de visualização muito superiores àqueles possíveis na atualidade. Os meios de comunicação irão aumentar a sensação da presencialidade de pessoas que estão distantes, ainda mais do que os recursos de videoconferência de hoje, que já impressionam pela alta qualidade. Ao menos na ficção, tecnologias desse tipo são tornadas comuns e seu alcance chega até a maior parte da população mundial.

Obviamente, sonhos futurísticos de autores de ficção não precisam ser calcados em comprovação científica e, portanto, os planejamentos da vida real não são influenciados por eles. Deve-se contar apenas com as possibilidades existentes e acessíveis, determinadas por dados pesquisados, testados e aprovados, que indiquem trajetórias viáveis e sensatas. Mesmo com todo

\footnotetext{
${ }^{79}$ A rede CAnet 3, gerenciada pela organização canadense Canarie (http://www.canarie.ca), utiliza tecnologias de fibras ópticas que possibilitam a transmissão de dados a 40Gbps (Gigabits por segundo).
} 
o contexto de música e tecnologia que foi colocado na introdução do trabalho, ainda existem limitações a considerar, tanto nas formas de comunicação musical como na quantidade de pessoas com acesso a esses recursos. Mas, se como diz Moran "o poder de interação está fundamentalmente nas nossas mentes", não há uma dependência de quadros tecnológicos mais avançados do que aquele que já existe. A realidade presente oferece diversas ferramentas para expandir e democratizar a educação musical, e o curso da UAB - UFSCar estudado nesta pesquisa é um exemplo disso. A ampliação da oferta de vagas para a formação de professores é significativa, de forma gratuita, criando multiplicadores que terão condições de repassar o que aprenderam para gerações futuras.

A educação musical a distância cria soluções para descentralizar o ensino que anteriormente era circunscrito a algumas cidades, em um sistema favorável a alunos que, se tivessem como única opção a educação presencial, não poderiam estudar. Sem complicações à vida familiar, alunos em faixas etárias superiores aos 30 anos podem concluir sua formação, enquanto mantém suas rotinas de trabalho já estabelecidas. Nessa situação, aplicam seus novos conhecimentos no dia-a-dia de suas regiões de origem, diretamente, ao contrário daqueles que precisam se transferir temporariamente para outras cidades. Dessa forma, é contornada uma dinâmica observada por Del Ben (2001: 298), em que futuros professores, primeiramente, aprendem música e depois, em um período de tempo bem mais curto, aplicam os conhecimentos musicais em contextos de ensino e aprendizagem. Mesmo para os professores em formação inicial, ainda se colocando no mercado de trabalho, são maiores as oportunidades para realizar um "casamento" entre teoria e prática, pois podem experimentar a vivência de estágios nos locais onde irão permanecer depois.

Considerando esse cenário mais abrangente, nesta tese o foco foi fechado para a questão da performance. Em resposta à questão colocada como hipótese da pesquisa, pode-se concluir que o ensino a distância de percussão é possível, sendo uma alternativa viável para a formação de professores de música. Após os estudos propostos, os participantes estavam aptos a tocar ritmos básicos com o pandeiro e com baquetas, obtendo boas sonoridades e mantendo andamentos consistentes. Além disso, aprenderam e discutiram sobre o uso de instrumentos de percussão na educação musical, entraram em contato com diferentes estilos de percussão com o compartilhamento de vídeos, e conheceram referências na Internet para se manterem atualizados. 
Retomando os termos de David Elliot que foram expostos no capítulo 5, chega-se à conclusão de que o aspecto procedimental da música pode ser trabalhado a distância. Com comunicações utilizando vídeos e feedbacks especializados, o desenvolvimento de aprendizes pode ser monitorado e estimulado, gerando competências em conceitos práticos para tocar instrumentos de percussão. Na investigação realizada nessa pesquisa, por se tratar da formação de professores de música, os conhecimentos procedimentais foram básicos e não houve a intenção de se alcançar níveis de excelência avançados, por serem considerados necessários apenas a instrumentistas profissionais da percussão. Nada indica que conteúdos mais complexos não sejam passíveis de estudo, dentro da mesma estrutura apresentada nessa tese, com a devida preparação de materiais e a participação de tutores capacitados.

Há, no entanto, diferenças em relação ao ensino presencial de percussão, com aspectos que apresentam maiores dificuldades e outros que têm seu estudo facilitado. O trabalho com conceitos procedimentais, realizado por meio de vídeos gravados, sem comunicações visuais síncronas, é funcional com baquetas e com o pandeiro, mas teve limitações no tratamento de problemas surgidos ao longo de um curso. A demonstração de exercícios com instrumentos musicais ocorre de forma satisfatória, havendo benefícios ao aluno pela repetição contínua de determinadas imagens e pela edição de diferentes tomadas, que proporcionam ângulos de visão variados de um mesmo movimento. Mas, com grupos formados por dezenas de alunos, é impraticável produzir um novo vídeo para cada pergunta feita, ou para esclarecer dúvidas individuais sobre os exercícios propostos.

Nesse sentido, os tutores virtuais do sistema UAB - UFSCar têm uma grande responsabilidade, por ter que lidar com questões complexas em respostas escritas, descrevendo o que seria mais facilmente gerenciado em situações face a face. Indagações preocupantes, como aquelas sobre as dores musculares relatadas por alguns alunos, criam desafios delicados e de difícil resolução, mesmo em cursos presenciais. Relatos de músicos mostram que esse não é um problema exclusivo dos instrumentos de percussão, mas as consequiências das ações exigidas nos exercícios realizados na disciplina estudada foram imediatas. Com outros instrumentos, como o piano ou o violão, lesões causadas por esforço repetitivo surgem no decorrer de períodos mais prolongados. No estudo com baquetas e com o pandeiro, o impacto resultante das forças aplicadas é parcialmente transferido para as mãos e pulsos dos estudantes, gerando dores em 
curto prazo. $\mathrm{O}$ enfrentamento dos problemas usuais pode ser feito pelos tutores, mas é essencial que os alunos com históricos anteriores de lesões, arriscados de evoluir para síndromes mais graves, sejam encaminhados para médicos especialistas.

Em relação aos conteúdos abordados na disciplina, o uso de vídeos produzidos antes das aulas não permite a mesma flexibilidade dos cursos presenciais. Se uma turma tiver muitos alunos avançados, que já vivenciaram a percussão e desejam aperfeiçoar alguns elementos de sua performance, em uma aula face a face um sub-grupo pode ser formado, com conteúdos específicos, em momentos estratégicos. Em cursos a distância, no formato da UAB - UFSCar, parte dos materiais pedagógicos é "fechada", pré-programada, observando os objetivos gerais estabelecidos. Trabalhando com instrumentos musicais, na formação de professores de música, essa limitação padroniza os alunos como iniciantes. Na percussão, por exemplo, foram estudados ritmos básicos de samba e baião no pandeiro, mas aqueles que já dominavam esses conteúdos poderiam começar a disciplina em outro ponto, com versões mais elaboradas ou outros ritmos.

Percebe-se que a educação a distância é, ao mesmo tempo, aberta e fechada. Enquanto há uma abertura para o acesso de maiores contingentes populacionais aos processos educacionais, em grande parte os currículos são fechados, criando desafios para o gerenciamento de custos no momento de renovar materiais de estudo. Para que se possa construir um curso de boa qualidade, a elaboração e a produção dos materiais exige condições favoráveis, com equipes e equipamentos especializados, gerando produtos: o ambiente virtual de aprendizagem, o livreto que acompanha essa tese, os vídeos e as partituras que demonstram exercícios.

Baseados na experiência com as primeiras turmas da disciplina, pode-se concluir que o resultado com os vídeos é bastante satisfatório, cumprindo a finalidade a que foram propostos. Os exercícios demonstrados foram compreendidos e contribuíram para o desenvolvimento dos alunos, nos procedimentos específicos que estavam planejados. Mas, por outro lado, foram insuficientes para lidar com a insegurança dos alunos em relação às suas performances. As dúvidas surgidas na tentativa de emular movimentos do professor, para amplos esclarecimentos, precisariam de comunicações síncronas, com interatividade entre professor (ou tutores) e alunos. O pedido de momentos presenciais com o professor, vindo dos alunos, revela que para tornar viável o ensino de percussão no sistema UAB - UFSCar, é preciso planejar e valorizar esses encontros. 
Portanto, como foi destacado no capítulo 4, o suporte de conhecimentos específicos é muito importante. A pesquisa nessa área precisa de aprofundamentos, principalmente para investigar resultados com a videoconferência como meio de comunicação para aulas e resolução de dúvidas. Também é preciso analisar como conteúdos mais avançados podem ser trabalhados, em uma possível continuidade dos estudos de percussão. É fundamental ressaltar que a disciplina, na forma em que foi preparada, ministrada e estudada nessa tese, está direcionada a professores de música em formação, sem experiências anteriores com instrumentos de percussão. Há um enorme campo investigativo quando se discute performance, com uma vasta amplitude de perfis de aluno, do iniciante ao instrumentista profissional, que demanda diferentes olhares, com ênfases específicas caso a caso.

Atenções também deverão ser dirigidas aos sistemas automatizados, que muito provavelmente serão empregados por gestores educacionais, sempre que possível, para cortar gastos e expandir o número de alunos atendidos. Na realização dessa pesquisa, ficou comprovado que, no ensino de percussão, o feedback ao aluno não pode ser automático. Conforme foi observado, em outras áreas do estudo musical, as respostas dadas por softwares são suficientes para a realização de alguns exercícios, mas a colocação disso em favor de uma compreensão musical mais ampla requer contextualização, discussão e reflexão. Em práticas com instrumentos musicais, pode-se treinar a leitura de partituras com o computador, que fornece uma porcentagem de erros e acertos, mas não comenta a qualidade da interpretação, os detalhes dos fraseados ou os pontos a melhorar. É um exercício importante, assim como outros que poderão ser tornados automáticos de alguma maneira, mas que precisa ser complementado por comentários, críticas e sugestões, tendo um professor ou tutores como observadores.

O conhecimento musical chamado de formal, proposicional (ElLIOT, 1995), informacional ou factual (SWANWICK, 1994), tendo um ambiente virtual de aprendizagem como meio centralizador de conteúdos, atividades e comunicações, apresentou possibilidades diversificadas e interessantes. Com o Moodle, muitas informações sobre percussão foram compartilhadas pelos alunos, contribuindo para elevar as discussões da disciplina e exemplificar aplicações educacionais do que foi estudado. Foram visualizadas imagens de projetos sociais, de atividades educacionais e de instrumentistas em ação, inserindo os exercícios propostos em um contexto e estabelecendo ligações com assuntos também abordados em outras disciplinas do 
curso. Nesse aspecto, a distância entre os participantes de um programa de estudos realizado a distância pode ser um elemento de grande riqueza, pois realidades bem diferentes, provenientes das regiões onde vivem os alunos, são confrontadas e discutidas.

Sem dúvida, as facilidades de comunicação também se estendem aos cursos presenciais, que passam a contar com a "presença virtual" de palestrantes convidados e com informações coletadas em localidades distantes, sem deslocamentos e com baixos investimentos. Em algum percentual, todo curso se torna híbrido, pois o contato presencial entre mestre e aprendiz dificilmente escapará de ter conteúdos externos adentrando o processo educacional. Ao assistir ao mesmo concerto dezenas de vezes, em DVD ou em vídeos no YouTube, o aluno desenvolve saberes que leva para a aula. Ao praticar com livros de play-along, ao acessar websites de artistas, ao conectar as informações de "métodos" impressos, vídeo-aulas e CDs, ele recebe um pouco de várias fontes, quebrando a hegemonia do professor como única via de acesso ao conhecimento. Com todos os meios de comunicação musical observados no capítulo 3, há um processo de encurtamento nas distâncias entre estudantes de música e conteúdos educacionais, que vem ocorrendo de forma mais evidente nas últimas décadas e se acentuou com as tecnologias digitais.

Parece natural que educadores musicais se aproveitem dessa situação, tanto como uma extensão de aulas presenciais como em cursos a distância. A participação em comunidades virtuais de música, conforme discutido no capítulo 4, também parece ser uma etapa comum para os estudantes, ampliando seus círculos informacionais e divulgando os recursos educacionais abertos existentes na Internet. O que muda é o equilíbrio entre o "presencial" e o "a distância", dependendo das condições de cada caso, das rotinas dos participantes e de onde eles se encontram. É provável que, nos próximos anos, a distinção entre esses dois tipos de curso seja diluída, com o surgimento de disciplinas realizadas a distância dentro de programas presenciais, sem diferenças a considerar no histórico escolar dos alunos concluintes.

No Brasil, para que se possa falar em uma "educação musical a distância" consistente, sólida e reconhecidamente efetiva, um longo caminho tem sido percorrido em passos largos, chegando até os cursos formais da UAB, com a chancela do Ministério da Educação. Investigando a Licenciatura em Educação Musical da UAB - UFSCar, essa pesquisa procurou contribuir para o desenvolvimento desse campo, em uma de suas áreas que mais poderão 
modificar o futuro da educação musical brasileira: a formação de professores de música. Resultando como agentes multiplicadores os formandos desse curso, a EAD terá uma grande importância também na educação presencial, com professores mais preparados e licenciados legalmente para exercer sua profissão.

Sendo a música um tema complexo e portador de diversos tipos de conhecimento, mais pesquisas são necessárias, para que o amplo espectro de assuntos relacionados comece a ser coberto. Não somente a performance com todas as famílias de instrumentos deve ser objeto de estudo, mas também o ensino de cada uma das disciplinas musicais, observando suas características e desafios. Certamente, além de documentar o progresso de cursos e projetos na área, as investigações acadêmicas poderão mostrar os caminhos futuros da educação musical a distância, tornando realidade muitas cenas que um dia existiram apenas na ficção científica. 


\section{REFERÊNCIAS BIBLIOGRÁFICAS}

ABED. ABRAEAD - Anuário brasileiro estatístico de educação aberta e a distância 2008. São Paulo: ABED / Instituto Monitor, 2008.

ADELMAN, Clem e KEMP, Anthony E. Estudo de caso e investigação-ação. In: KEMP, Anthony E. (ed.). Introdução à investigação em educação musical. Lisboa: Fundação Calouste Gulbenkian, p. 111-134, 1995.

ANDERSON, Terry. Students services in a networked world. In: BRINDLEY, Jane E.; WALTI, Christine e ZAWACKI-RICHTER, Olaf (Eds.). Learner support in open, distance and online learning environments. Olderburg: Bibliotheks-und Informationssystem der Carl von Ossietzky Universität Oldenburg, p. 95-108, 2004.

BANNAN, Nicholas e GOHN, Daniel M. Career development for music teachers through international distance-learning media. In: Em Pauta. Revista do Programa de Pós-Graduação em Música da UFRGS, v. 15, n. 24, p.141-153, 2004.

BARBIER, René. A pesquisa ação. Brasília: Editora Plano, 2002.

BARRIÈRE, Françoise. Reflections on the state of electroacoustic music today: aesthetic evolution and relation with the public. In: Aesthetic and Electroacoustic Music. Acteon Mnemosyne, vol. 1, 1995.

BATES, A.W. (Tony). Technology, open learning and distance education. London: Routledge, 1995.

BELLONI, Maria L. Educação a distância. Campinas: Editora Autores Associados, 1999.

BERENDT, Joachim E. O jazz - do rag ao rock. São Paulo: Editora Perspectiva, 2007.

BINKLEY, Timothy. Transparent technology. The swan song of electronics. In: Leonardo. Vol. 28, no. 5, p. 427-432, 1995.

BIOCCA, Frank A. The pursuit of sound: radio, perception and utopian in the early twentieth century. In: Media, culture and society. London, Newbury Park, Beverly Hills and New Delhi: SAGE, Vol. 10, no.1, p.61-79, 1988.

BRAGA, Paulo. Oficina de violão: estrutura de ensino e padrões de interação em um curso coletivo a distância. Tese de Doutorado. Programa de Pós-Graduação em Música da Universidade Federal da Bahia. Salvador: UFBA, 2009.

BRAY, David. CD-ROM in music education. In: British Journal of Music Education, vol. 14, n. 2, p. 137-142, 1997. 
BRITO, Teca Alencar. Koellreutter educador: o humano como objetivo da educação musical. São Paulo: Editora Peirópolis, 2001.

CAIN, Tim. The characteristics of action research in music education. In: British Journal of Music Education, vol. 25, n. 3, p. 283-313, 2008.

CAJAZEIRA, Regina. Educação continuada a distância para músicos da filarmônica Minerva Gestão e Curso Batuta. Tese de Doutorado. Programa de Pós-Graduação em Música da Universidade Federal da Bahia. Salvador: UFBA, 2004. Disponível em: <www.dominiopublico.gov.br/download/texto/me001423.pdf> . Acessado em 28/06/09.

CHION, Michel. Música, media e tecnologias. Lisboa: Instituto Piaget, 1994.

COLEMAN, Mark. Playback. From the victrola to MP3, 100 years of music, machines, and money. Cambridge: Da Capo Press, 2003.

CONSANI, Marciel Aparecido. Avaliação de softwares na educação musical: modalidade percepção. Dissertação de Mestrado. Programa de Pós-Graduação em Música da Universidade Estadual Paulista Júlio de Mesquita Filho. São Paulo: UNESP, 2003.

COPLAND, Aaron. Music and imagination. Harvard University Press: Cambridge, 1952. What to listen for in music. New York: McGraw-Hill Book Company, 1939.

DEAL, Scott. Percussion on the Internet. In: Percussive Notes, vol. 43, no.2, p.74-77, 2005.

DEARLING, Robert e DEARLING, Celia. The guiness book of recorded sound. Middlesex: Guiness Books, 1984.

DEL BEN, Luciana. Múltiplos espaços, multidimensionalidade, conjunto de saberes: idéias para pensarmos a formação de professores de música. In: Revista da ABEM, Porto Alegre, v. 8, p. 2932, 2003.

. Concepções a ações de educação musical escolar: três estudos de caso. Tese de Doutorado. Programa de Pós-Graduação em Música da Universidade Federal do Rio Grande do Sul. Porto Alegre: UFGRS, 2001.

DEMO, Pedro. Tecnologia em educação e aprendizagem. In: Ensaio. Avaliação e políticas públicas em educação. Fundação Cesgranrio, Rio de Janeiro, v. 10, n. 35, p. 201-222, 2002.

DINELLO, Daniel. Technophobia! Science fiction visions of posthuman technology. Austin: University of Texas Press, 2005.

ELLIOT, David J. Music matters. A new philosophy of music education. New York: Oxford University Press, 1995. 
FICHEMAN, Irene Karanguilla et al. Editor musical: uma aplicação para a aprendizagem de música apoiada por meios eletrônicos interativos. In: Anais do XIV Simpósio Brasileiro de Informática na Educação (SBIE). Rio de Janeiro: SBC/NCE-UFRJ, 2003.

FLOWERS, Patricia J. What was that? Talking about what we hear in music. In: Update: Applications of Research in Music Education, vol. 21, no.2, p. 28-38, 2003.

FOLKESTAD, Göran. Formal and informal learning situations or practices vs. formal and informal ways of learning. In: British Journal of Music Education, vol. 23, n. 2, p. 135-145, 2006.

FONTERRADA, Marisa T. de O. De tramas e fios: um ensaio sobre música e educação. São Paulo: Editora UNESP, 2005.

GOHN, Daniel Marcondes. EAD e o estudo da música. In: LITTO, Fredric Michael e FORMIGA, Marcos (org.). Educação a distância: o estado da arte. São Paulo: Pearson Education, p. 282-288, 2008.

Educação musical a distância: experiências com construção de instrumentos. In: Anais do XVI Encontro Nacional da Associação Brasileira de Educação Musical (ABEM). Campo Grande, UFMT, 2007. CD-ROM.

Auto-aprendizagem musical: alternativas tecnológicas. São Paulo: Editora Annablume, 2003.

GOHN, Maria da Glória. Educação não-formal e o educador social. In: Revista de Ciências da Educação-UNISAL, n. 19, p. 121-140, 2008.

GOULD, Glenn. The prospects of recording. In: Audio culture: readings in moderns music. Cox, C. \& Warner, D. (Eds.). New York: Continuum, p. 115-130, 2004.

GREEN, Lucy. Music, informal learning and the school: a new classroom pedagogy. Hampshire: Ashgate Publishing, 2008.

HENDERSON FILHO, José Ruy. Formação continuada de professores de música em ambiente de ensino e aprendizagem online. Tese de Doutorado. Programa de Pós-Graduação em Música da Universidade Federal do Rio Grande do Sul. Porto Alegre: UFGRS, 2007.

HODGES, Richard. Using ICT in music teaching. In: PHILPOTT, C. and PLUMMERIDGE, C. (eds.). Issues in music teaching. London: Routledge, 2001.

HOLLOWAY, Marguerite. Pattie. In: Wired magazine. Edição 5/12/1997. Disponível em: <http://www.wired.com/wired/archive/5.12/maes.html>. Acessado em 14/06/2007.

HUXLEY, Aldous. Brave new world. New York: HarperPerennial, 1989. Primeira edição da obra em 1932, prefácio incluído na edição de 1946. 
HYLAND, Fiona. Providing effective support: investigating feedback to distance language learners. In: Open Learning, vol. 16, n. 3, p. 233-247, 2001.

JAQUES-DALCROZE, Emile. Rhythm, music \& education. London: The Riverside Press, 1967.

JOLY, Ilza Zenker Leme; SANTIAGO, Glauber e GOHN, Daniel. Projeto do curso de Licenciatura em Educação Musical da UFSCar, modalidade educação a distância. São Carlos: UFSCar, 2007.

JONES, Steve. Rock formation. Music, technology, and mass communication. Newbury Park: Sage Publications, 1992.

JONES, Steven E. Against technology: from luddites to neo-luddism. New York: Routledge, 2006.

JORGENSEN, Estelle. Transforming music education. Bloomington: Indiana University Press, 2003.

KATZ, Mark. Capturing sound. How technology has changed music. Berkeley: University of California Press, 2004.

KEMBER, David. Reconsidering open \& distance learning in the developing world. Meeting student's learning needs. London and New York: Routledge, 2007.

KENYON JONES, Christine. The people's university. 150 years of the University of London and its external students. London: University of London, 2008.

KRÜGER, Susana E. Educação musical apoiada pelas novas Tecnologias de Informação e Comunicação (TIC): pesquisas, práticas e formação de docentes. In: Revista da ABEM, Porto Alegre, v. 14, p. 75-89, 2006.

Desenvolvimento, testagem e proposta de um roteiro para avaliação de software para educação musical. Dissertação de Mestrado. Programa de Pós-Graduação em Música da Universidade Federal do Rio Grande do Sul. Porto Alegre: UFGRS, 2000.

KUSEK, David e LEONHARD, Gerd. The future of music. Manifesto for the digital music revolution. Boston: Berklee Press, 2005.

LANE, Andy. Am I good enough? The mediated use of open educational resources to empower learners in excluded communities. In: Access to learning for development. The fifth pancommonwealth forum on open learning. (Anais eletrônicos). The commonwealth of learning and the University of London, 13 a 18 de julho de 2008. Disponível em:

<http://www.wikieducator.org/images/f/f2/PID_405.pdf>. Acessado em 26/06/09.

LEME, Mônica Neves et al. Navegando e aprendendo música no portal: uma experiência interdisciplinar no Colégio Pedro II. In: Anais do XVII Encontro Nacional da Associação 
Brasileira de Educação Musical (ABEM). São Paulo, UNESP, 2008. CD-ROM.

LENTELL, Helen. The importance of the tutor in open and distance learning. In: TAIT, Alan e MILLS, Roger (eds.). Rethinking learner support in distance education. Change and continuity in an international context. London: RoutledgeFalmer, p. 64-76, 2003.

LITTO, Fredric Michael. Public policy and distance learning in Brazil. In: EVANS, Terry; HAUGHEY, Margaret e MURPHY, David (eds.). International handbook of distance education. Bingley, UK: Emerald Group Publishing, p. 671-684, 2008a.

ICT policies and practices in education in Brazil. In: PLOMP, Tjeerd (ed.). Crossnational ICT policies and practices in education (revised edition). Connecticut: Information Age Publishing, 2008b.

Recursos educacionais abertos. In: LITTO, Fredric Michael e FORMIGA, Marcos (org). Educação a distância. O estado da arte. São Paulo: Pearson Education, p. 304-309, 2008c.

A nova ecologia do conhecimento: conteúdo aberto, aprendizagem e desenvolvimento. In: Inclusão social, v. 1, n. 2, Brasília, p. 60-65, 2006.

A universidade e o futuro do planeta. In: MORHY, Lauro (org.). A universidade em questão. Brasília: Editora Universidade de Brasília, p. 99-113, 2003.

The hybridization of distance learning in Brazil - an approach imposed by culture. In: International review of research in open and distance learning, vol. 2, no. 2, 2002.

MARK, Michael L. (ed.). Music education. Source readings from ancient Greece to today. New York: Routledge, 2002.

MASON, Robin. On-line learning and supporting students. New possibilities. In: TAIT, Alan e MILLS, Roger (eds.). Rethinking learner support in distance education. Change and continuity in an international context. London: RoutledgeFalmer, p. 90-101, 2003.

MASON, Robin e RENNIE, Frank. eLearning. The key concepts. London: Routledge, 2006.

MAYOR, Barbara e SWANN, Joan. The English language and 'global' teaching. In: LEA, Mary R. e NICOLL, Kathy (eds.). Distributed learning. Social and cultural approaches to practice. London: RoutledgeFalmer, p. 111-130, 2002.

McCUTCHEON, Mark A. Techno, Frankenstein and copyright. In: Popular music, Vol. 26, n. 2, p. 259-280, 2007.

MCLUHAN, Marshall. Understanding media: the extensions of man. New York: Signet Books, 1964.

MENDES, Giann e BRAGA, Paulo. Estrutura e recursos tecnológicos num curso de violão a 
distância. In: Anais do XVII Congresso da ANPPOM (Associação Nacional de Pesquisa e PósGraduação em Música). São Paulo: UNESP, 2007.

MILLS, Janet e MURRAY, Andy. Music technology inspected: good teaching in Key Stage 3. In: British Journal of Music Education, vol. 17, n. 2, p. 129-156, 2000.

MOORE, Michael e KEARSLEY, Greg. Educação a distância. Uma visão integrada. São Paulo: Thomson Learning, 2007.

MORAN, José Manuel. Ensino e aprendizagem inovadores com tecnologias audiovisuais e telemáticas. In: MORAN, José Manuel; MASETTO, Marcos T.; Behrens, Marilda Aparecida. Novas tecnologias e mediação pedagógica. Campinas: Papirus Editora, 2002.

MOREIRA, Sonia Virgínia. Rádio em transição. Tecnologias e leis nos Estados Unidos e no Brasil. Rio de Janeiro: Mil Palavras, 2002.

NETTO, Samuel Pfromm. Telas que ensinam. Mídia e aprendizagem: do cinema ao computador. Campinas: Editora Alínea, 2001.

NISKIER, Arnaldo. Educação à distância. A tecnologia da esperança. São Paulo: Edições Loyola, 1999.

OBLINGER, Diana G. e OBLINGER, James L. Is it age or IT: first steps towards understanding the net generation. In: OBLINGER, Diana G. e OBLINGER, James L. (eds.). Educating the net generation. Boulder: Educause, p. 2.1-2.20, 2005.

OECD. Giving knowledge for free. The emergence of open educational resources. Paris: OECD Publishing, 2007.

OLCOS. Open educational practices and resources. OLCOS roadmap 2012. Editado por Guntram Geser, Salzburg Research / EduMedia Group, 2007. Disponível em $<$ http://www.olcos.org>. Acessado em 21/03/2009.

OLIVEIRA, Fernanda de Assis. A inserção do Youtube na aula de piano: um relato de experiência. In: Anais do XVI Encontro Nacional da Associação Brasileira de Educação Musical (ABEM). São Paulo, UNESP, 2008. CD-ROM.

PENNA, Maura. Não basta tocar? Discutindo a formação do educador musical. In: Revista da ABEM, Porto Alegre, v. 16, p. 49-56, 2007.

PERRATON, Hilary. Open and distance learning in developing countries. London: Routledge, 2000.

PHILLIP, Robert. Implications for the future. In: Early recordings and musical style: changing tastes in instrumental performance, 1900-1950. New York: Cambridge University Press, p. 229240, 1992. 
POSTMAN, Neil. Technopoly. The surrender of culture to technology. New York: Vintage Books, 1993.

Amusing ourselves to death. Public discourse in the age of show business. New York: Penguin books, 1985.

PYNCHON, Thomas R. Is it ok to be a luddite? In: The New York Times Book Review. 28 Out. 1984, p. 1, 40-41. Disponível em <http://www.themodernword.com/pynchon/pynchon_ essays_luddite.html>. Acessado em 21/11/2007.

RAY, Sonia e ANDREOLA, Xandra. O alongamento muscular no cotidiano do performer musical: estudos, conceitos e aplicações. In: Musica hodie, vol. 5, n. 1, p. 21-34, 2005.

RHEINGOLD, Howard. The virtual community.Homesteading on the electronic frontier. Reading: Addison-Wesley Publishing Company, 1993.

RIDELL, Alistair. Data culture generation: after content, process as aesthetic. In: Leonardo. Vol. 34 , n. 4, p. 337-343, 2001.

SALAVUO, Miikka. Open and informal online communities as forums of collaborative musical activities and learning. In: British Journal of Music Education, vol. 23, n. 3, p. 253-271, 2006.

SALLES, Pedro Paulo. A reinvenção da música pela criança: implicações pedagógicas da criação musical. Tese de Doutorado. Programa de Pós-Graduação em Educação da Universidade de São Paulo. São Paulo: FEUSP, 2002.

SANTIAGO, Glauber Lúcio Alves. Questionário para alunos da UAB - UFSCar. Pesquisa não publicada, fornecida pelo autor. São Carlos, 2009.

SANTIAGO, Patrícia Furst. A integração da prática deliberada e da prática informal no aprendizado da música instrumental. In: Per musi. Revista Acadêmica de Música, Belo Horizonte, n. 13, p. 52-62, 2006.

SEDDON, Frederick A. Collaborative computer-mediated music composition in cyberspace. In: British Journal of Music Education, vol. 23, n. 3, p. 273-283, 2006.

SESSIONS, Roger. The musical experience of composer, performer, listener. New York, Atheneum, 1962. (First published by Princeton University Press in 1950).

SMALL, Christopher. Music, society, education. Hanover: Wesleyan University Press, 1996.

SMIALEK, Thomas et. al. The effect of cooperative listening exercises on the critical listening skills of college music-appreciation students. In: Journal of Research in Music Education, vol. 54, n. 1, p. 57-72, 2006. 
SOUZA, Cássia Virgínia Coelho. Educação musical a distância no Brasil. In: OLIVEIRA, Alda e CAJAZEIRA, Regina (org.). Educação musical no Brasil. Salvador: Editora P\&A, p. 385-389, 2007.

. Programa de Educação Musical a Distância para professores séries iniciais do ensino fundamental: um estudo de caso. Tese de Doutorado. Programa Pós-Graduação em Música da Universidade Federal da Bahia. Salvador: UFBA, 2003.

SOUZA, Jusamara. (org.). Aprender e ensinar música no cotidiano. Porto Alegre: Editora Sulina, 2008.

SOUSA, John Philip. The menace of mechanical music. In: Appleton's Magazine, vol. 8, n. 3, p. 278-84, 1906.

SWANWICK, Keith. Musical knowledge. Intuition, analysis and music education. London: Routledge, 1994.

SYMES, Colin. A sound education: the gramophone and the classroom in the United Kingdom and the United States, 1920-1940. In: British Journal of Music Education, vol. 21, n. 2, p. 163$178,2004$.

TAIT, Alan. Rethinking learner support in the Open University UK. A case study. In: TAIT, Alan e MILLS, Roger (eds.). Rethinking learner support in distance education. Change and continuity in an international context. London: RoutledgeFalmer, p. 185-197, 2003.

THÉBERGE, P. Music/ Technology/ Practice. In: Any sound you can imagine: making music / consuming technology. Hanover - London, Weslayan University Press. p.157-185, 1997.

THIOLLENT, Michel. Metodologia da pesquisa-ação. São Paulo: Editora Cortez, 1985.

THOMPSON, Emily. Machines, music, and the quest for fidelity: marketing the Edison phonograph in America: 1977-1925. In: The Musical Quarterly, vol. 79, n. 1, p. 131-171, 1995.

THORPE, Mary. From independent learning to collaborative learning. In: LEA, Mary R. e NICOLL, Kathy (eds.). Distributed learning. Social and cultural approaches to practice. London: RoutledgeFalmer, p. 131-151, 2002.

WATSON, Scott (ed.). Technology guide for music educators. Boston: Thomson Course Technology, 2006.

WEBER, Max. Os fundamentos racionais e sociológicos da música. São Paulo: Edusp, 1995.

WEBB, Michael. Music analysis down the (you) tube? Exploring the potential of cross-media listening for the music classroom. In: British Journal of Music Education, vol. 24, n. 2, p. 147164, 2007. 


\section{Lista de websites}

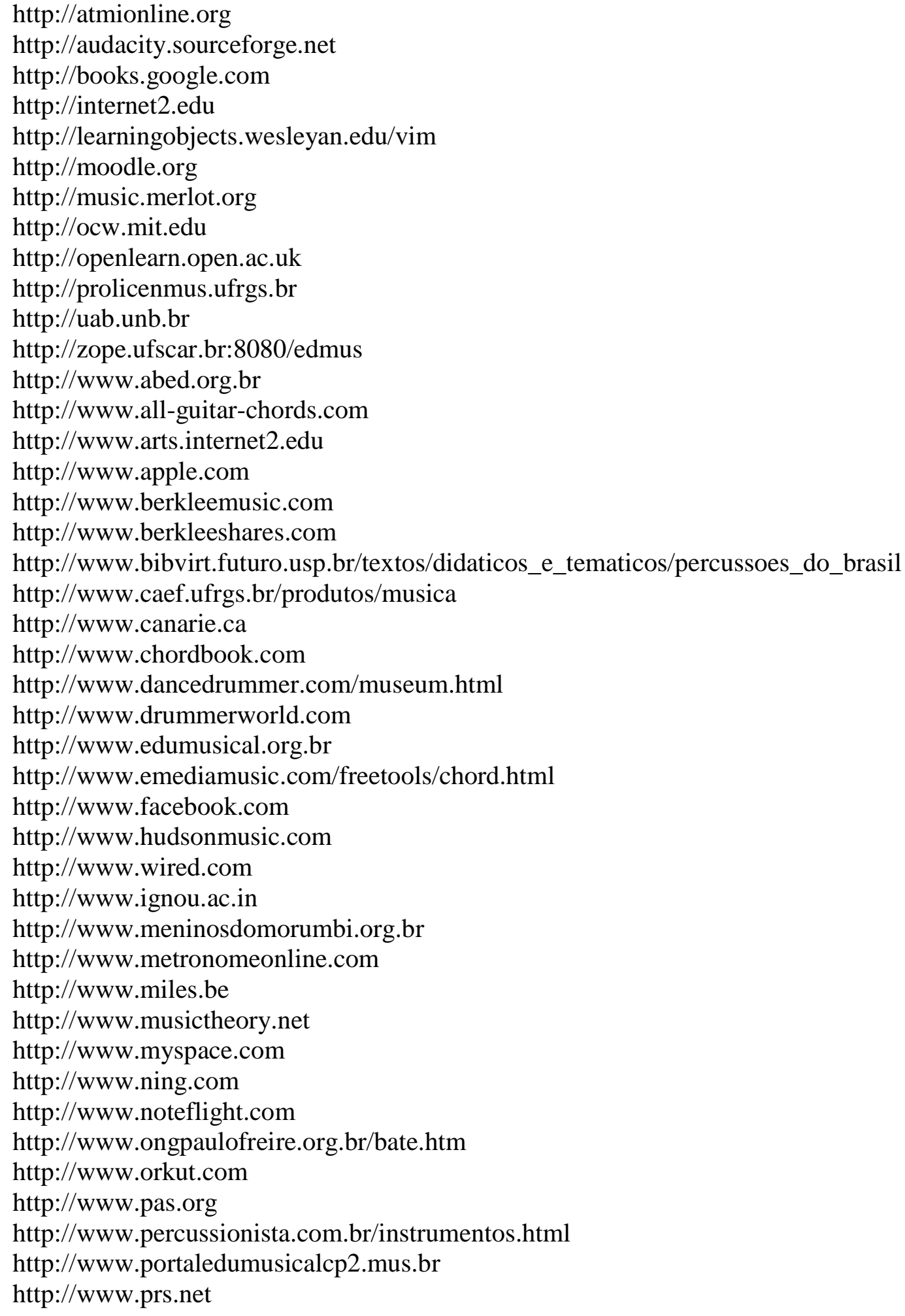


http://www.ronimusic.com

http://www.schooltube.com

http://www.sibelius.com

http://www.teachertube.com

http://www.tonomundo.com.br

http://www.uab.mec.gov.br

http://www.universia.com.br/mit

http://www.unwater.org

http://www.usq.edu.au

http://www.virtualschoolofmusic.com

http://www.vtmidi.org

http://www.youtube.com 


\section{ANEXO A}

Disciplinas do curso de Licenciatura em Educação Musical, modalidade Educação a Distância, UAB - UFSCar, segundo o projeto pedagógico (Joly, Santiago e Gohn, 2007).

\begin{tabular}{|l|}
\hline Módulo 1A (16 semanas) \\
\hline Introdução à educação a distância \\
\hline Introdução aos recursos tecnológicos musicais \\
\hline Prática e ensino em educação musical1 \\
\hline Vivência em educação musical 1 \\
\hline Módulo 1B (8 semanas) \\
\hline Percepção e notação musical1 \\
\hline Linguagem e estruturação musical1 \\
\hline Construção de instrumentos para educação musical1 \\
\hline Vivência em educação musical1 \\
\hline Módulo 1C (8 semanas) \\
\hline Fundamentos da comunicação escrita na língua inglesa para profissionais de \\
educação musical 1 \\
\hline Introdução aos métodos, técnicas e fundamentos em educação musical \\
\hline Vivência em educação musical 2 \\
\hline Módulo 2A (8 semanas) \\
\hline Língua portuguesa \\
\hline Percepção e notação musical 2 \\
\hline Prática e ensino em educação musical 2 \\
\hline Vivência em educação musical 3 \\
\hline Módulo 2B (8 semanas) \\
\hline Educação a distância para Educação Musical1 \\
\hline Fundamentos de arte-educação \\
\hline Linguagem e estruturação musical 2 \\
\hline Vivência em educação musical 4 \\
\hline Módulo 3A (8 semanas) \\
\hline Didática Geral e da Música \\
\hline Prática e ensino em educação musical 3 \\
\hline
\end{tabular}




\begin{tabular}{|c|c|}
\hline Percussão & \\
\hline Vivência em educação musical5 & \\
\hline Módulo 3B (8 semanas) & \\
\hline Percepção e notação musical 3 & \\
\hline $\begin{array}{l}\text { Fundamentos da comunicação escrita na líng } \\
\text { educação musical2 }\end{array}$ & ua inglesa para profissionais de \\
\hline Linguagem e estruturação musical3 & \\
\hline Vivência em educação musical 6 & \\
\hline Módulo 4A (8 semanas) & \\
\hline Educação a distância para Educação Musical 2 & \\
\hline História da música e da educação musical 1 & \\
\hline Criação musical1 & \\
\hline Vivência em educação musical 7 & \\
\hline Módulo 4B (8 semanas) & \\
\hline Psicologia do Desenvolvimento & \\
\hline Tópicos em educação, cultura e sociedade 1 & \\
\hline Linguagem e estruturação musical 4 & \\
\hline Vivência em educação musical 8 & \\
\hline Módulo 5A (8 semanas) & \\
\hline Tecnologia musical 1 & \\
\hline Psicologia da Aprendizagem & \\
\hline Prática e ensino em educação musical 4 & \\
\hline Vivência em educação musical 9 & \\
\hline Módulo 5B (8 semanas) & \\
\hline Tecnologia de internet & \\
\hline Tópicos em educação, cultura e sociedade 2 & \\
\hline História da música e da educação musical 2 & \\
\hline Vivência em educação musical10 & \\
\hline Módulo 6A (8 semanas) & \\
\hline Educação a distância para educação musical 3 & \\
\hline Tecnologia de multimídia1 & \\
\hline Criação musical 2 & \\
\hline Vivência em educação musical 11 & \\
\hline Módulo 6B (8 semanas) & \\
\hline
\end{tabular}


Tecnologia de multimídia 2

Tópicos em educação, cultura e sociedade 3

Construção de instrumentos para educação musical 2

Vivência em educação musical 12

Módulo 7A (8 semanas)

Prática e ensino em educação musical 5

Princípios de ecologia sonora

Princípios de gestão de projetos

Vivência em educação musical 13

Módulo 7B (8 semanas)

Tecnologia musical 2

Metodologia e prática do ensino em educação musical

Estágio em educação musical 1

Vivência em educação musical 14

Módulo 8A (8 semanas)

Produção de material didático para educação musical

Estágio em educação musical 2

Projeto em educação musical 1

Vivência em educação musical 15

Módulo 8B (8 semanas)

Percepção musical aplicada à educação

Projeto em educação musical 2

Estágio em educação musical 3

Vivência em educação musical 16

Módulo 9A (8 semanas)

Prática e ensino em educação musical 6

Projeto em educação musical 3

Estágio em educação musical 4

Vivência em educação musical 17

Módulo 9B (8 semanas)

Prática e ensino em educação musical 7

Estágio em educação musical 5

Projeto em educação musical 4 


\begin{abstract}
ANEXO B
Lista de vídeos da disciplina Percussão. As letras ao final de cada item indicam: (b) baquetas; (p) pandeiro; (s) surdo; (t) triângulo. As referências a mão direita e mão esquerda são baseadas nas imagens dos vídeos, de um instrumentista destro.
\end{abstract}

1) Apresentação do professor, falando sobre os objetivos da disciplina.

2) Dicas para a aquisição de baquetas e do pandeiro.

3) Dicas para comprar ou construir um pad de estudo.

4) Demonstração de posturas para praticar e de como segurar e movimentar as baquetas (b).

5) Demonstração do "movimento chicote" e a diferença no som resultante, comparado com o "movimento travado". O objetivo é deixar a membrana de um tambor tocado vibrar, deixando a ponta da baqueta em contato o menor tempo possível (b).

6) Exercício de toque simples, alternando as mãos, primeiro com $80 \mathrm{bpm}$ e depois com 110 bpm (b).

7) Exploração das sonoridades do pandeiro: som graves, deixando a pele vibrar por completo, sem abafar (p).

8) Toques alternados do pulso com toques das pontas dos dedos, demonstrados primeiro com 60 bpm e depois com 120 bpm. Em seguida, movimento do pandeiro com a mão esquerda, girando o pulso para coordenar o instrumento com os toques da mão direita (p).

9) Demonstração do paraddidles, com exemplos em 50 bpm, 70 bpm e 90 bpm (b). 
10) Toques abertos e fechados alternados, com movimento dos dedos da mão esquerda, abafando e soltando a parte de baixo da pele (p).

11) Demonstração de samba no pandeiro, em 80 bpm e em 100 bpm (p).

12) Padrão rítmico do surdo, com a mão esquerda abafando a pele na primeira nota e soltadoa para vibrar livremente na segunda. No final, algumas variações são demonstradas (s).

13) Para discutir o assunto "andamento", as baquetas são utilizadas para tocar figuras rítmicas: primeiro "correndo", ou seja, sempre adiantando a colocação das notas em relação a uma marcação de metrônomo; depois "atrasando", deixando o ritmo um pouco atrás de cada tempo; e, por último, tocando exatamente com a marcação, procurando soar como uma máquina (b).

14) Exercício de toque duplo, demonstrando como dois sons são obtidos com um único movimento de cada mão (b).

15) Exercício “2 e 2": primeiro com 70 bpm e depois com 100 bpm (b).

16) Adição do tapa no samba, tocando com a mão aberta no centro da pele, produzindo um som curto e seco (p).

17) Demonstração da peça para caixa clara, transcrita na página143 (b).

18) Exercícios de baião no pandeiro: primeiramente só com a acentuação da $4^{\mathrm{a}}$ nota e depois com o toque do polegar (p).

19) Padrão rítmico com o triângulo: para os sons fechados, os dedos da mão que segura o instrumento abafam as notas; para os sons abertos, os dedos se abrem (t). 


\begin{abstract}
ANEXO C
Instruções para a realização da prova presencial.
\end{abstract}

\title{
Organização para a prova:
}

A prova será realizada com cada indivíduo tocando separadamente, um após o outro. Todos os alunos podem estar na sala e assistir o que os outros tocam, ou poderão ser chamados para a sala um de cada vez (os tutores devem decidir sobre isso baseados nos espaços que têm nos pólos e no que pensam ser mais apropriado para cada grupo específico).

Na parte da frente da sala, deixar arrumado um banquinho, uma caixa clara montada sobre uma estante, um par de baquetas e um pandeiro. Na frente da caixa clara, deverá estar uma estante de partituras, com uma cópia impressa da "peça para caixa clara", disponível no Moodle, na Unidade 5. Cada aluno pode tocar com suas baquetas e seu pandeiro, mas é importante que a falta desses equipamentos não seja um impedimento para a realização da prova. Também é preciso ter um metrônomo disponível.

Depois de explicado o que será pedido, os alunos podem ir para frente por ordem alfabética.

\section{Conteúdos:}

A prova irá constatar o desenvolvimento dos alunos com dois elementos que já foram praticados durante o semestre:

a) Tocar o samba no pandeiro (com o tapa), durante 30 segundos. Metrônomo em 60 bpm.

b) Tocar a peça para caixa clara, estudada na unidade 5. Metrônomo em 70 bpm. 


\section{Critérios para avaliação:}

a) Andamento - o aluno conseguiu manter o andamento quando tocou?

Ao tocar, alguns alunos poderão deixar de ouvir a marcação do metrônomo e variar o andamento. Embora a precisão não seja o mais importante na prova, o metrônomo serve para verificar se as variações foram grandes, e somente em casos extremos deverão ser descontados pontos.

b) Acentos - o aluno teve consistência nas dinâmicas?

Na peça para caixa, a dinâmica deve ser observada. Todas as vezes que uma seqüência de notas "forte" for tocada, ela deverá ter a mesma intensidade das outras notas "forte". O mesmo vale para as notas "piano".

c) Desenvoltura - os ritmos tocados estão bem articulados?

Os ritmos apresentados devem ser resultados de movimentos bem articulados e não "travados". Provavelmente, esse item é o que melhor indica se houve regularidade do aluno nas práticas com os instrumentos.

d) Avanço - o aluno se desenvolveu durante o semestre?

Nos casos em que os tutores percebam avanços do aluno, a nota deverá representar essa melhora, independente da comparação desse com outros alunos. Por exemplo, se dois alunos tocam o samba no pandeiro: o primeiro com facilidade, pois já é percussionista; o segundo com mais dificuldade, mas fica evidente que houve um bom progresso; os dois devem obter boas notas.

De uma forma geral, as boas notas devem valorizar aqueles que estudaram bastante. Não se deve apenas premiar quem toca bem (pois isso poderia já acontecer antes). A participação nas atividades presenciais também pode influenciar a decisão para as notas, indicando se houve avanços nos estudos. 